\title{
Hanford Site Groundwater Monitoring: Setting, Sources and Methods
}

\author{
Editor \\ M.J. Hartman
}

February 2000

Prepared for the U.S. Department of Energy under Contract DE-ACO6-76RLO 1830 


\title{
DISCLAIMER
}

This report was prepared as an account of work sponsored by an agency of the United States Government. Reference herein to any specific commercial product, process, or service by trade name, trademark, manufacturer, or otherwise does not necessarily constitute or imply its endorsement, recommendation, or favoring by the United States Government or any agency thereof, or Battelle Memorial Institute.

\author{
PACIFIC NORTHWEST NATIONAL LABORATORY \\ operated by \\ BATTELLE \\ for the \\ UNITED STATES DEPARTMENT OF ENERGY \\ under Contract DE-AC06-76RLO 1830
}

\author{
Printed in the United States of America \\ Available to DOE and DOE contractors from the \\ Office of Scientific and Technical Information, P.O. Box 62, Oak Ridge, TN 37831; \\ prices available from (615) 576-8401. \\ Available to the public from the National Technical Information Service, \\ U.S. Department of Commerce, 5285 Port Royal Rd., Springfield, VA 22161
}

This document was printed on recycled paper. 


\section{DISCLAIMER}

Portions of this document may be illegible in electronic image products. Images are produced from the best available original document. 


\section{Hanford Site \\ Groundwater Monitoring: \\ Setting, Sources and Methods}

\section{Editor}

M. J. Hartman

February 2000

Prepared for the U.S. Department of Energy by Pacific Northwest National Laboratory under Contract DE-AC06-76RLO 1830

Pacific Northwest National Laboratory Richland, Washington 99352 
○

○

- 


\section{Acknowledgments}

I compiled the text, tables, and figures in this document almost entirely from Hanford Site Groundwater Monitoring for Fiscal Year 1998 (PNNL-12086). The authors of the sections used here are Brent Barnett, Charissa Chou, Evan Dresel, Barb Gillespie, Duane Horton, Vern Johnson, Jon Lindberg, John McDonald, Rich Mercer, Susan Narbutovskih, Darrell Newcomer, Bob Peterson, Steve Reidel, Virginia Rohay, Jeff Serne, Mark Sweeney, Chris Thompson, Paul Thorne, Ed
Thornton, Bill Webber, and Bruce Williams. Chris Newbill produced the maps. I thank each of these silent authors for their contributions.

Bob Riley provided a technical peer review. Launa Morasch did the editorial review, and she, Kathy Neiderhiser, and Lila Andor prepared the document for the Internet.

Mary J. Hartman 
-

-

- 


\section{Summary}

This report is a companion volume to the groundwater monitoring report for the Hanford Site, which is produced annually. It contains background information that does not change significantly from year to year.

The following regulations govern groundwater monitoring on the Hanford Site: Resource Conservation and Recovery Act of 1976, Comprehensive Environmental Response, Compensation, and Liability Act of 1980, U.S. Department of Energy orders, and the Washington Administrative Code. The Hanford Federal Facility Agreement and Consent Order, an agreement between the Department of Energy, Washington Department of Ecology, and the U.S. Environmental Protection Agency, is used to coordinate groundwater protection and remedial action efforts.

Unconsolidated sediment of the Hanford and Ringold formations comprises the uppermost aquifer beneath the Hanford Site. These formations contain highly permeable layers of sand and gravel interbedded with less permeable layers of silt and clay. Groundwater flows primarily from west to east, but influences of liquid waste disposal disrupt this pattern locally.

Facilities that produced significant amounts of liquid waste, or waste sites that require groundwater monitoring, are located mainly in the 100,200, and 300 areas. A few additional sites are located in the 400,600 , and Richland North areas. Most of these waste sites are inactive.
Selection of groundwater monitoring wells, constituents, and sampling frequencies are based on knowledge of waste disposal practices, regulatory requirements, proximity to disposal areas, contaminant mobility, and site hydrogeology. The groundwater project measures water levels in wells across the Hanford Site annually, and the data are used to create a water-table map. Staff use more frequent measurements to create trend plots for wells near specific waste sites. Groundwater chemistry is determined from samples collected near waste sites and across the Hanford Site. Samples are collected monthly, quarterly, or semiannually in wells near regulated waste units, and less frequently at distal locations. Usually, samples are analyzed using U.S. Environmental Protection Agency methods. These data are used to construct contaminant trend plots and maps of contaminant distribution. The data also are used to comply with regulations and conduct statistical comparisons.

Monitoring of the vadose zone includes geophysical logging of boreholes and soil-vapor monitoring. Borehole logging includes moisture, gross gamma, and, more recently, spectral gamma methods. Individual gamma-producing radionuclides are measured with the spectral technique. This is most often used near underground storage tanks to detect movement of contaminants in the sediment beneath the tanks. In the 200 West Area, vadose zone contamination is being remediated using a soil-vapor extractions system. The success of the cleanup is monitored with vadose wells and probes. 
○

-

- 


\section{Contents}

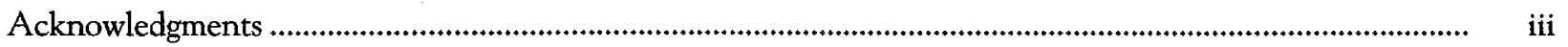

Summary

s.

1.0 Introduction

2.0 Groundwater Monitoring Requirements .

2.1 Environmental Monitoring

2.2 Groundwater Protection

2.2.1 General Environmental Protection Program .

2.2.2 Radiation Protection of the Public and the Environment

2.3 Hanford Federal Facility Agreement and Consent Order......

2.4 Applicable Federal Regulations

2.4.1 Comprehensive Environmental Response, Compensation, and Liability Act of 1980/

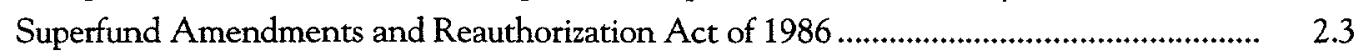

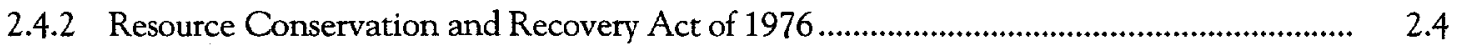

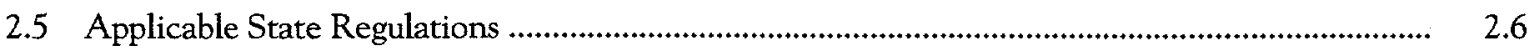

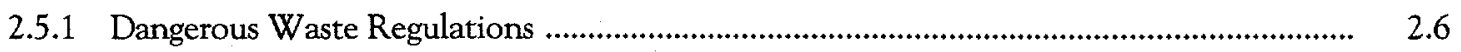

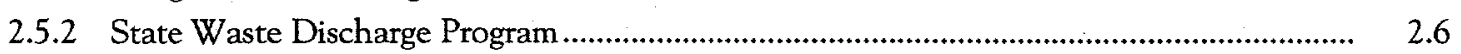

2.5.3 Minimum Functional Standards for Solid Waste Handling .................................................. . 2.6

2.5.4 Model Toxics Control Act - Cleanup ................................................................................ 2.6

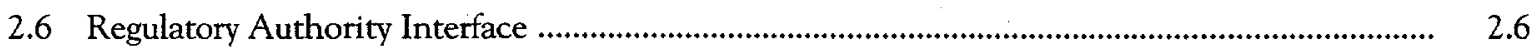

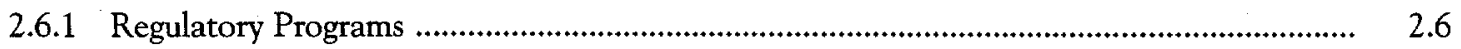

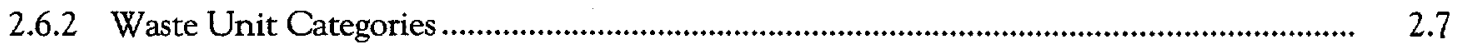

2.6.3 Management of Waste Management Units ........................................................................ 2.7

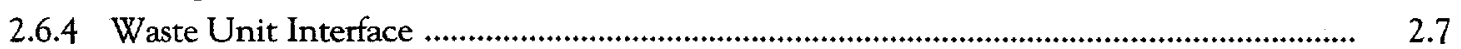

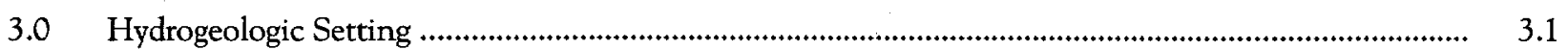

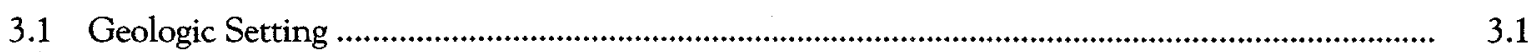

3.1.1 Columbia River Basalt Group ....................................................................................... 3.2

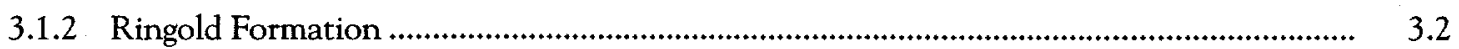

3.1.3 Plio-Pleistocene Unit and Early Palouse Soil ................................................................ 
3.1.4 Hanford Formation and Pre-Missoula Gravels ............................................................................ 3.3

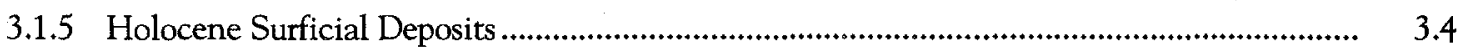

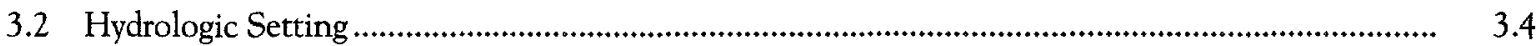

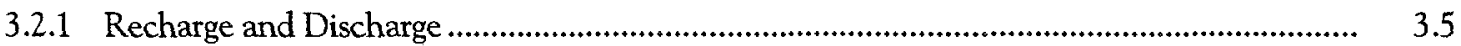

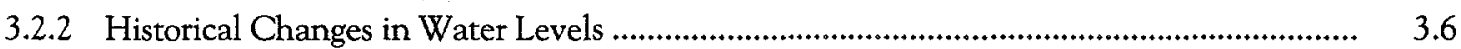

3.2.3 Hydraulic Properties ...................................................................................................... 3.6



4.1100 Areas

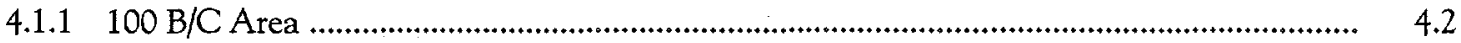

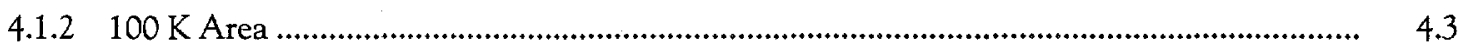

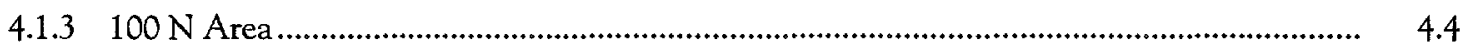

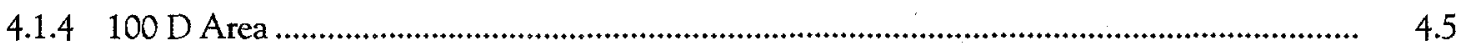

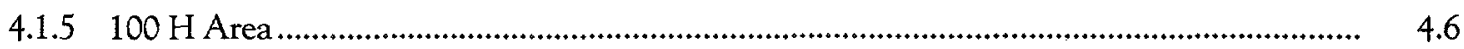

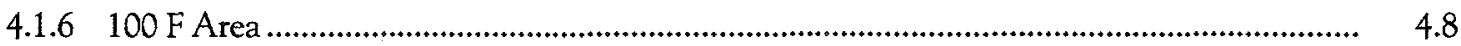

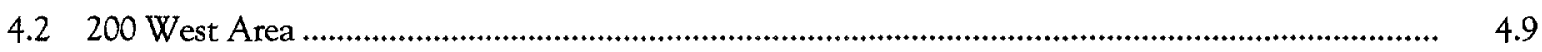

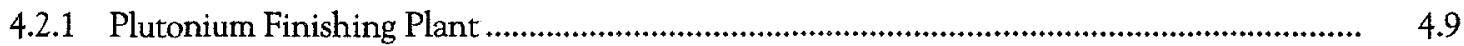

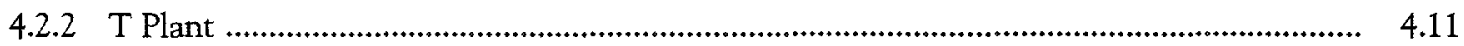

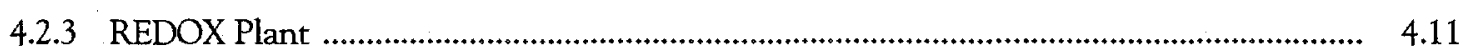

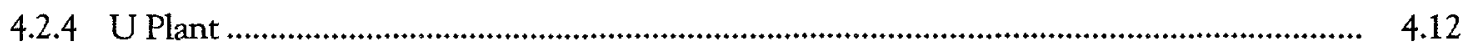

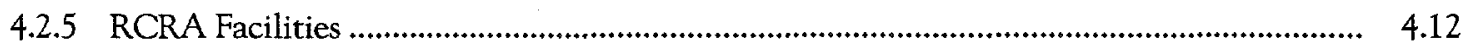

4.2.5.1 Single-Shell Tank Farms in 200 West Area ......................................................... 4.12

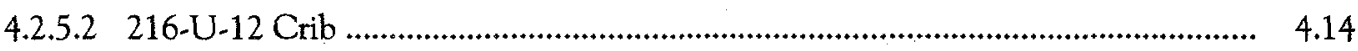

4.2.5.3 216-S-10 Pond and Ditch .............................................................................. 4.14

4.2.5.4 Low-Level Waste Management Areas in 200 West Area....................................... 4.15

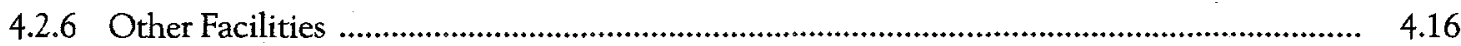

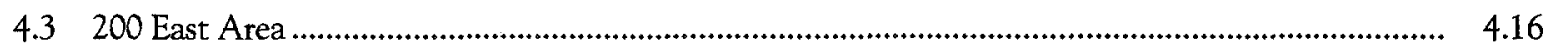

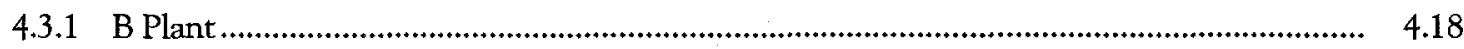

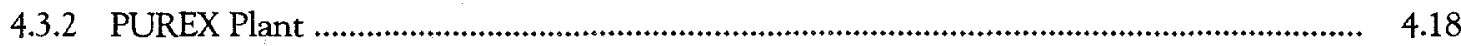

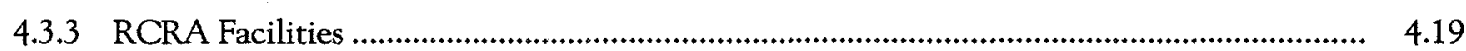

4.3.3.1 RCRA-Regulated PUREX Cribs ..................................................................... 4.19

4.3.3.2 216-A-29 Ditch ............................................................................................. 4.20

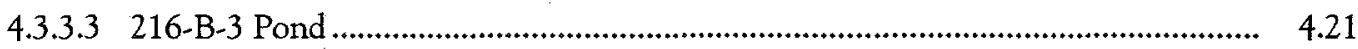

4.3.3.4 216-B-63 Trench ...................................................................................... 4.22

4.3.3.5 Single-Shell Tank Farms in 200 East Area .......................................................... 4.22

4.3.3.6 Low-Level Waste Management Areas in 200 East Area ......................................... 4.23

4.3.3.7 Liquid Effluent Retention Facility ……................................................................ 4.24

4.3.4 200 Areas Treated Effluent Disposal Facility ................................................................. 4.25 


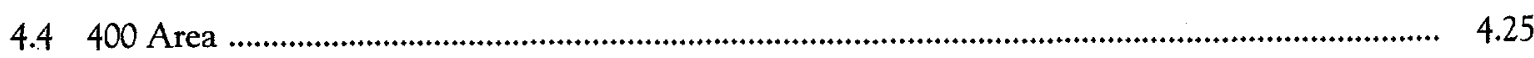

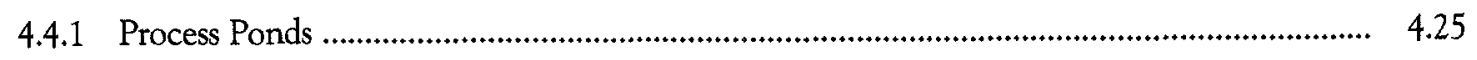

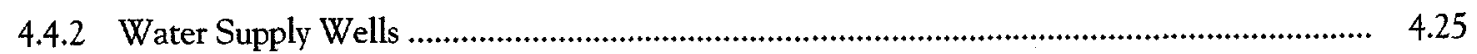

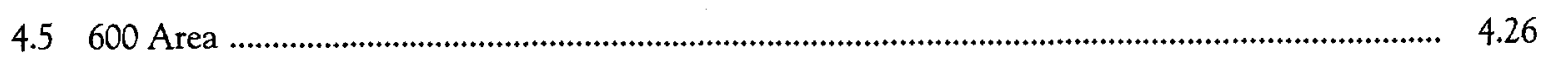

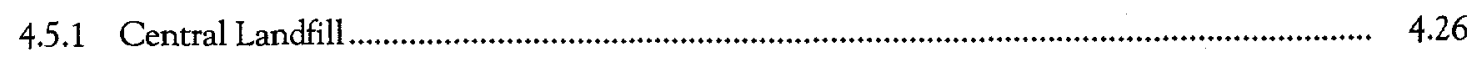

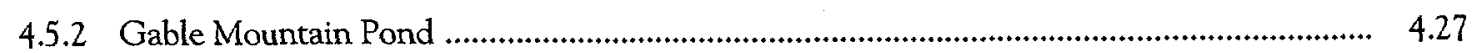

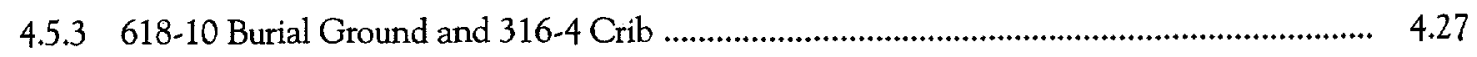

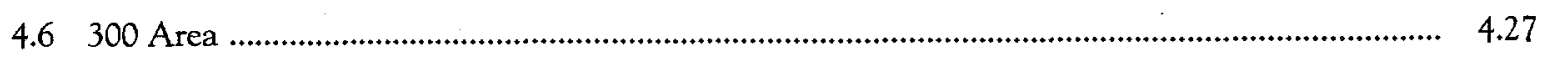

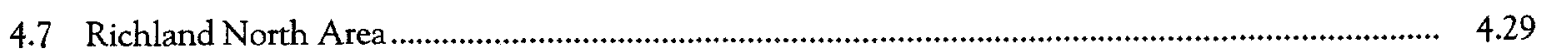

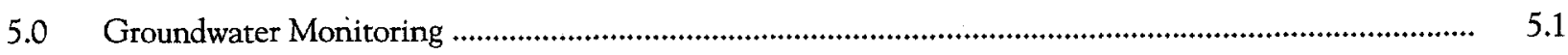

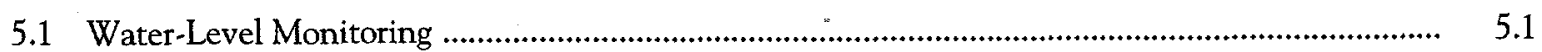

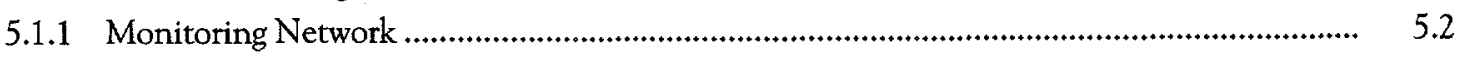

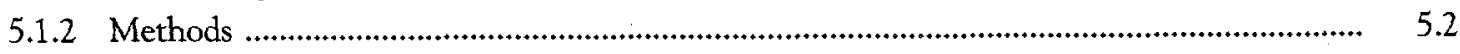

5.1.3 Data Quality .............................................................................................................. 5.2

5.1.4 Interpretive Techniques ..........................................................................................

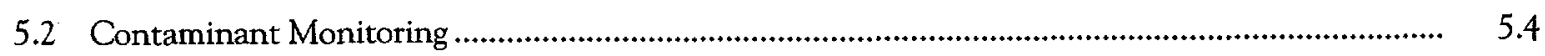

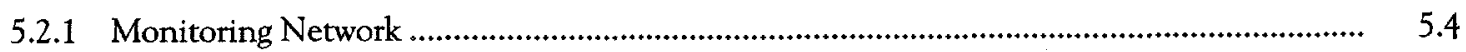

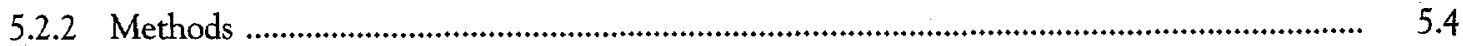

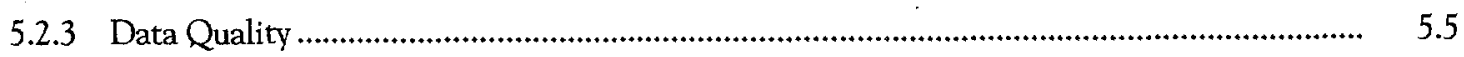

5.2.4 Interpretive Techniques ................................................................................................ 5.5

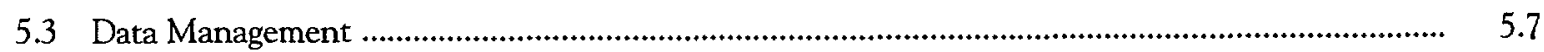

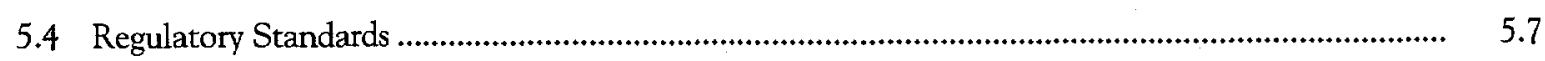

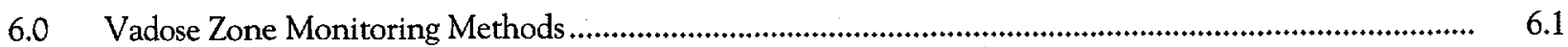

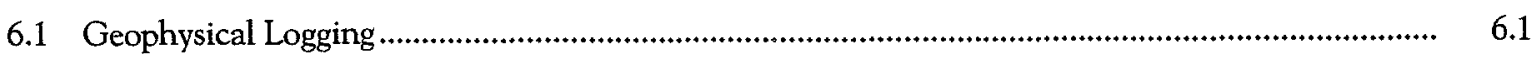

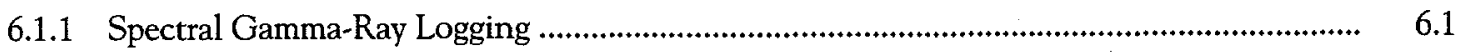

6.1.2 Neutron Moisture Logging .......................................................................................... 6.1

6.1.3 Time Lapse Comparison of Gamma Logs .................................................................. 6.2

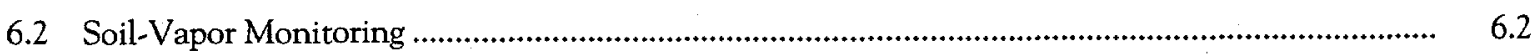

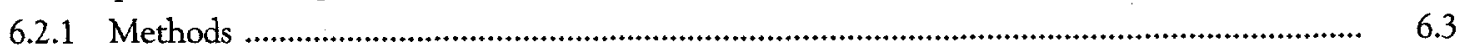

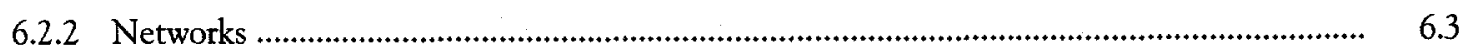


7.0 Statistical Methods

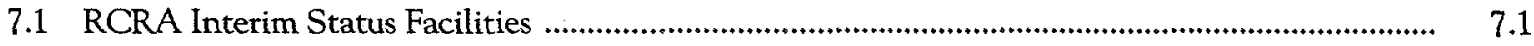

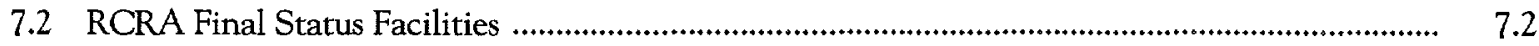

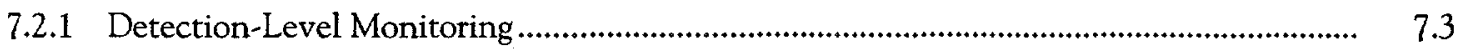

7.2.2 Compliance-Level Monitoring …...................................................................................... 7.4

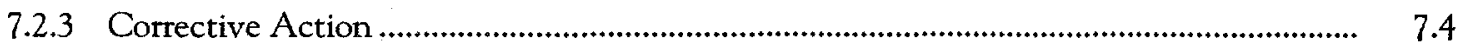

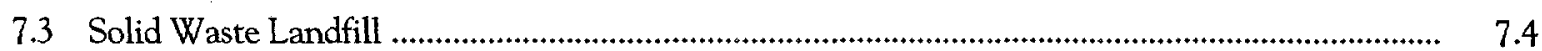

7.3.1 Calculating Background Summary Statistics........................................................................ 7.4

7.3.2 Testing Assumption of Normality of Data .......................................................................... 7.5

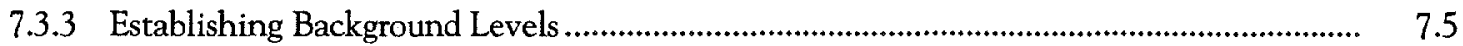

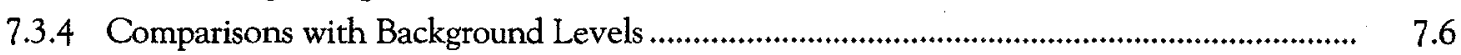

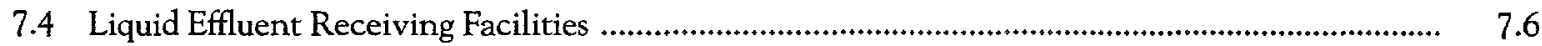

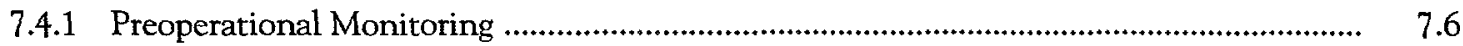

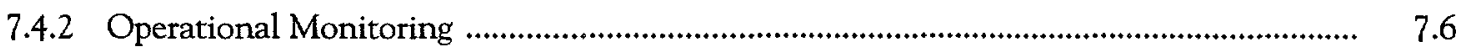

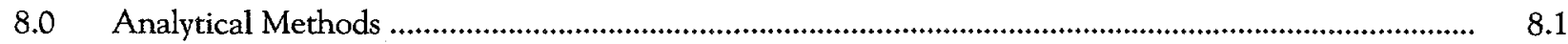

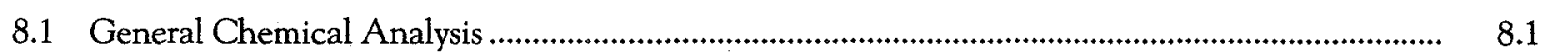

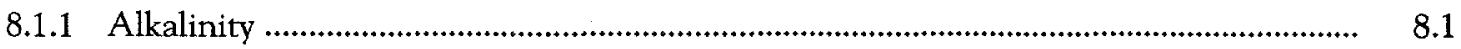

8.1.2 Chemical Oxygen Demand …....................................................................................... 8.1

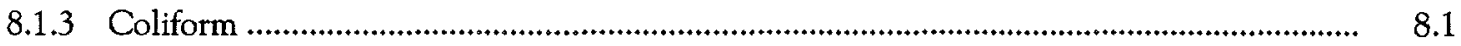

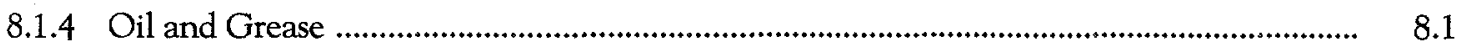

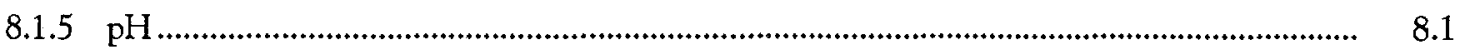

8.1.6 Specific Conductance ..................................................................................................... 8.2

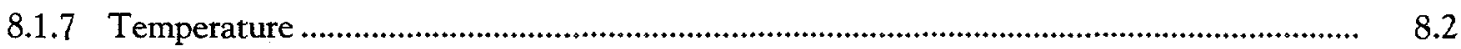

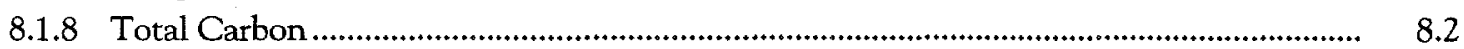

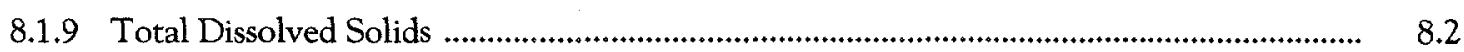

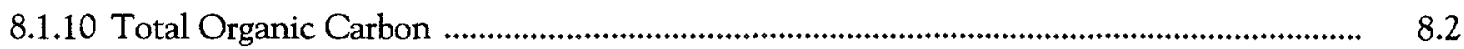

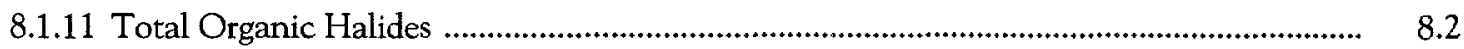

8.1.12 Total Petroleum Hydrocarbons .................................................................................... 8.2

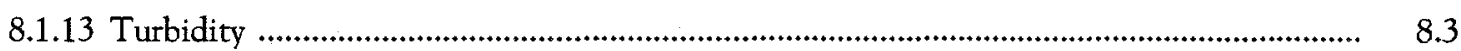

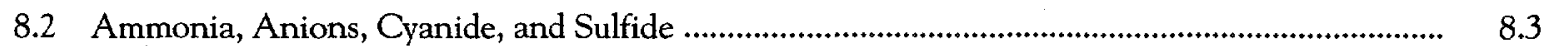

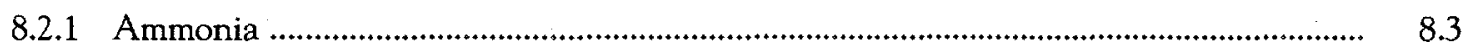

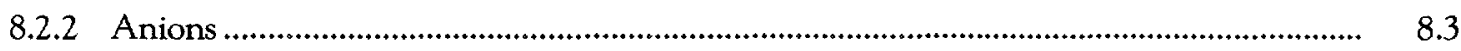

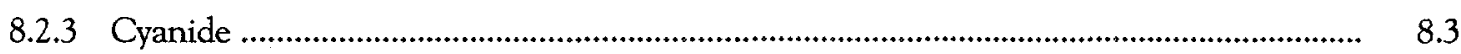

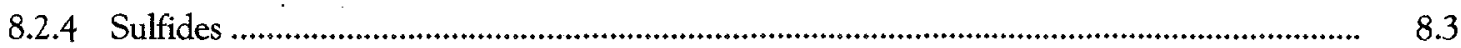




8.4 Semivolatile Organic Compound Analyses

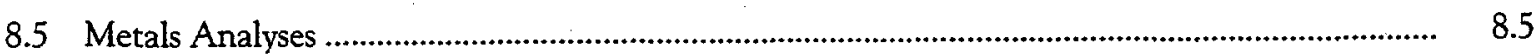

8.5.1 Atomic Absorption ............................................................................................... 8.5

8.5.2 Inductively Coupled Plasma Atomic Emission Spectroscopy …...................................... 8.5

8.5.3 Hexavalent Chromium ....................................................................................... 8.5

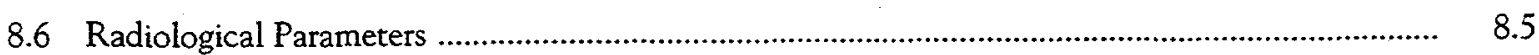

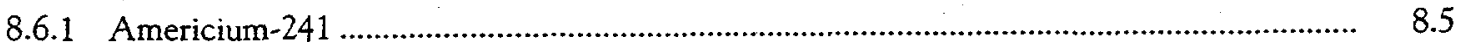

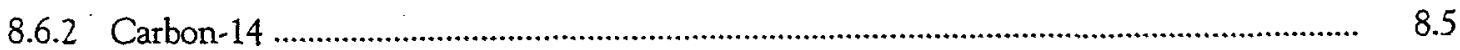

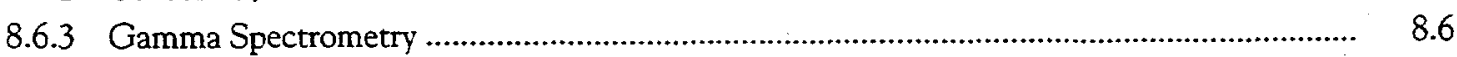

8.6.4 Gross Alpha and Gross Beta ................................................................................ 8.6

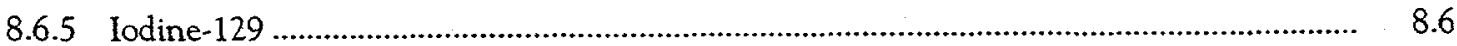

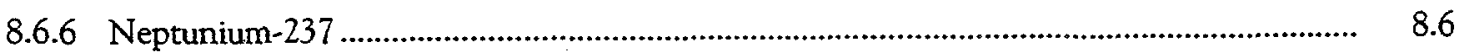

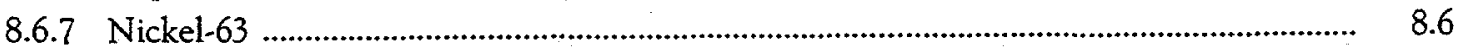

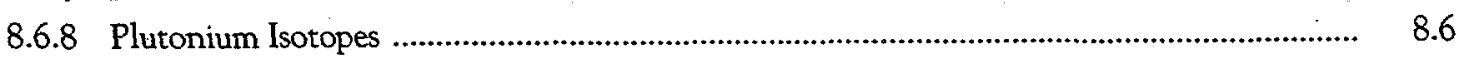

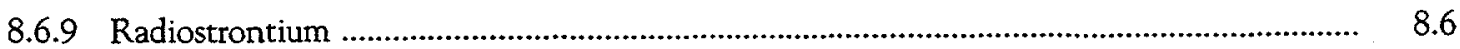

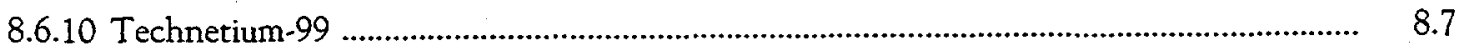

8.6.11 Total Alpha - Radium ................................................................................................. 8.7

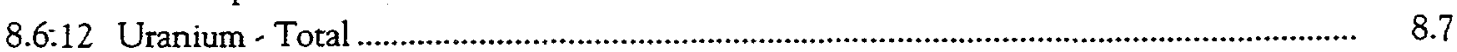

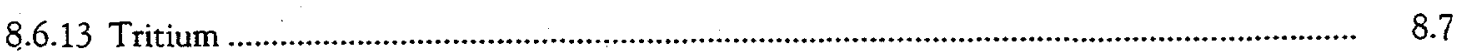

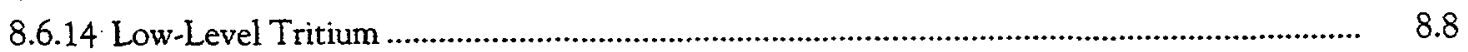

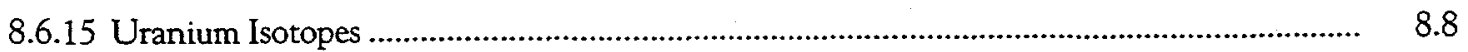

9.0 Glossary of Quality Assurance and Quality Control Terms ............................................................

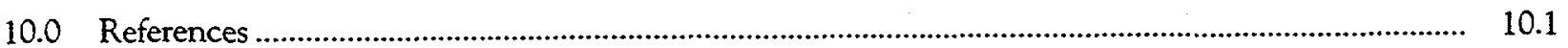




\section{Tables}

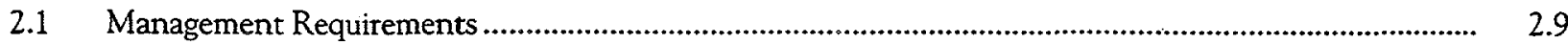

2.2 Groundwater Operable Unit Monitoring Status .......................................................................... 2.10

5.1 Maximum Contaminant Levels and Interim Drinking Water Standards ............................................. 5.9

5.2 Derived Concentration Guides and 4-mrem Effective Dose Equivalent Concentrations for Drinking Water

8.1 Methods Used to Obtain Routine Data Results for Project Samples

\section{Figures}

1.1 Hanford Site Location Map

2.1 Relationship Between Environmental Protection Programs and Plans

2.11

3.1 Pasco Basin Surface Geology and Structural Features

3.2 Comparison of Generalized Hydrogeologic and Geologic Stratigraphy

3.3 Hydrogeologic Units Present at Water Table, June 1998.

3.4 Hanford Site Geologic Cross-Section

3.5 Estimated Annual Recharge from Infiltration of Precipitation and Irrigation

3.6 Changes in Water-Table Elevations, 1944 Through 1979

3.7 Active Discharge Sites

3.8 Changes in Water-Table Elevations, 1979 Through 1995

3.9 Transmissivity Distribution from Model Calibration 


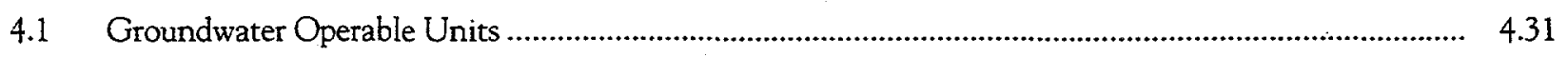

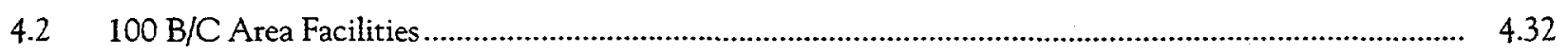

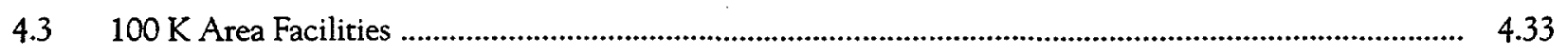

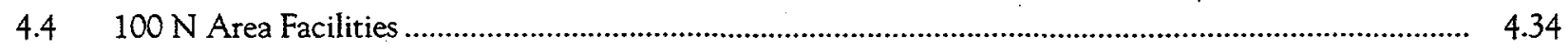

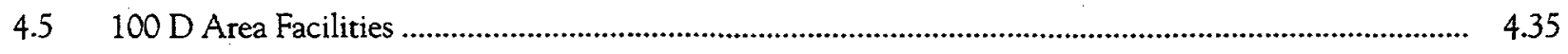



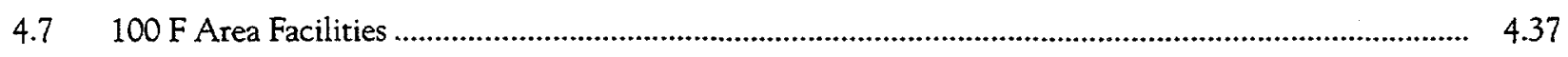

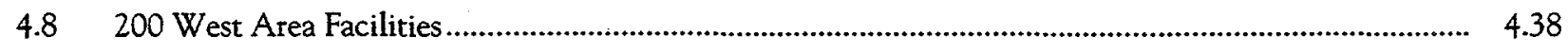

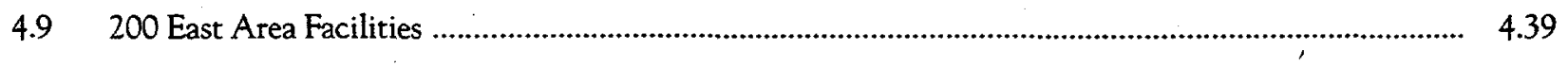

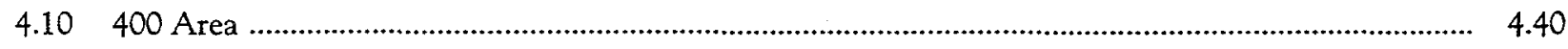

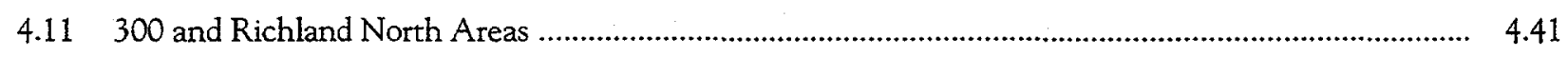

6.1 Location of Wells and Deep Soil-Vapor Monitoring Probes at the Carbon Tetrachloride Vapor

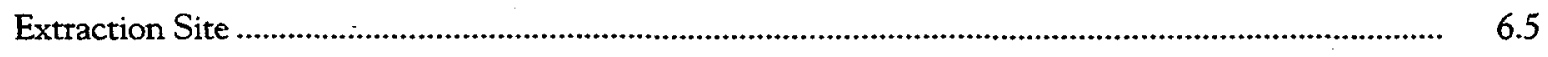

6.2 Location Map of Shallow Soil-Vapor Monitoring Probes at the Carbon Tetrachloride Vapor Extraction Site.... 


\subsection{Introduction}

Groundwater monitoring is conducted on the Hanford Site (Figure 1.1) to meet the requirements of the Resource Conservation and Recovery Act of 1976 (RCRA); Comprehensive Environmental Response, Compensation, and Liability Act of 1980 (CERCLA); U.S. Department of Energy (DOE) orders; and the Washington Administrative Code. Results of monitoring are published annually (e.g., PNNL-11989). To reduce the redundancy of these annual reports, background information that does not change significantly from year to year has been extracted from the annual report and published in this companion volume.
This report includes a description of groundwater monitoring requirements, site hydrogeology, and waste sites that have affected groundwater quality or that require groundwater monitoring. Monitoring networks and methods for sampling, analysis, and interpretation are summarized. Vadose zone monitoring methods and statistical methods also are described: Whenever necessary, updates to information contained in this document will be publișhed in future groundwater annual reports. 


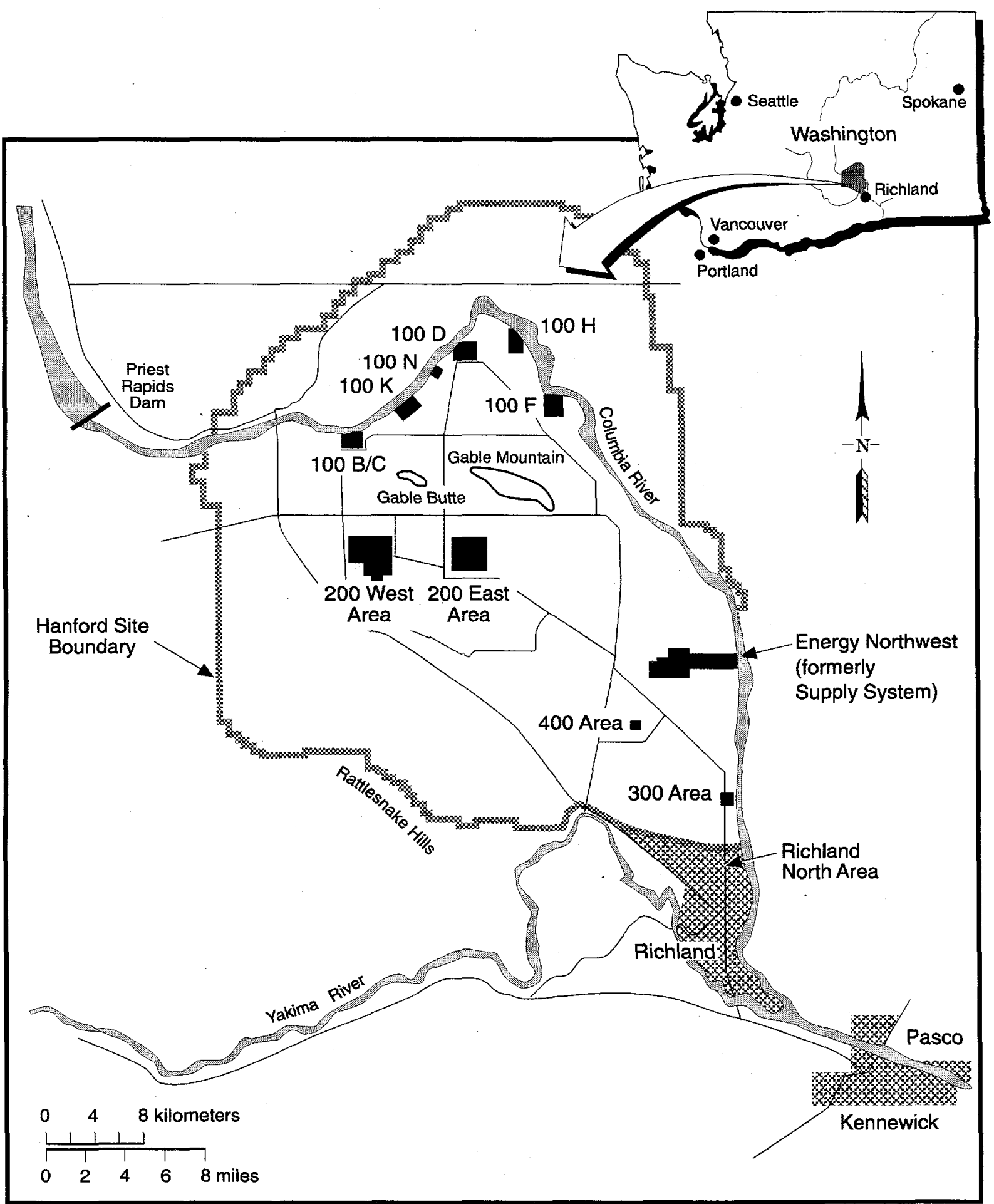

krno0001

Figure 1.1. Hanford Site Location Map 


\subsection{Groundwater Monitoring Requirements}

This section describes the various federal and state regulations, orders, and agreements that govern monitoring of groundwater on the Hanford Site. The Hanford Federal Facility Agreement and Consent Order (more commonly known as the Tri-Party Agreement; Ecology et al. 1989) provides the legal and procedural basis for cleanup and regulatory compliance at the numerous hazardous waste sites at the Hanford Site. The Tri-Party Agreement is the vehicle that coordinates groundwater monitoring and remediation activities under RCRA and CERCLA.

Under the Atomic Energy Act of 1954, as amended, the U.S. Department of Energy (DOE) is obligated "...to regulate its own activities so as to provide radiation protection for both workers and public."

The environmental standards and regulations applicable for groundwater protection/management and environmental monitoring are described in DOE Order 5400.1. These environmental protection standards are categorized as

- those imposed by federal regulations

- those imposed by state and local regulations

- those imposed by DOE directives.

The objectives of DOE's groundwater protection and environmental monitoring projects (as defined in DOE Order 5400.1) are to demonstrate compliance with regulations imposed by applicable federal, state, and local agencies; to confirm adherence to DOE environmental protection policies; and to support environmental management decisions.

The Hanford Site's environmental monitoring plan (DOE/RL-91-50, Rev. 2) and the groundwater protection management plan (DOE/RL-89-12, Rev. 2) summarize the groundwater and program integration activities and the regulatory reporting requirements for those activities. These plans integrate the following:

- near-field monitoring at active or inactive waste treatment, storage, or disposal (TSD) facilities to comply with RCRA, applicable State of Washington regulations, and operational monitoring required at nuclear facilities and untreated liquid waste disposal sites

- site-wide and offsite monitoring of contaminant migration required by DOE Order 5400.1

- site-specific groundwater monitoring to support groundwater remediation projects under CERCLA.

The following sections discuss the specific requirements in more detail.

\subsection{Environmental Monitoring}

Groundwater monitoring is a critical element of DOE's environmental monitoring project at the Hanford Site because an unconfined aquifer and a system of deeper confined aquifers underlie the site. Groundwater from the unconfined aquifer that enters the Columbia River provides one of the most significant pathways for transporting contaminants off the site.

Because the Hanford Site has multiple, extensive, and unique groundwater pollution problems, DOE has integrated groundwater monitoring to ensure protection of the public and the environment while improving the efficiency of monitoring operations. The environmental monitoring plan (DOE/RL-91-50, Rev. 2) documents the various elements of the groundwater monitoring project at the Hanford Site. As required by DOE Order 5400.1 , the plan addresses the highpriority elements of Environmental Regulatory Guide for Radiological Effluent Monitoring and Environmental Surveillance (DOE/EH-0173T). The relationship of the environmental monitoring plan to DOE Order 5400.1 
and to the various groundwater monitoring projects and reporting requirements is shown in Figure 2.1.

\subsection{Groundwater Protection}

DOE/RL-89-12, Rev. 2 provides a framework to coordinate the existing onsite groundwater protection activities conducted by DOE's contractors, establishes the policy and strategies for groundwater protection/ management at the Hanford Site, and proposes an implementation plan to meet goals (and milestones). These goals include (1) improving coordination between the federal and state regulations applicable to groundwater activities, (2) maintaining/achieving regulatory compliance of all groundwater activities, and (3) achieving cost-effective groundwater program administration. The relationship of DOE/RL-89-12, Rev. 2 to DOE Order 5400.1 and to the various groundwater monitoring, remedial activities, and reporting requirements is shown in Figure 2.1.

\subsubsection{General Environmental Protection Program}

Groundwater monitoring projects are established under DOE Order 5400.1 to meet the requirements of DOE Order 5400.5, which deals with radiation protection of the public and the environment, and federal and state regulations. DOE Order 5400.1 requires that groundwater monitoring projects be designed and implemented in accordance with the Code of Federal Regulations ( 40 CFR 264 or 40 CFR 265, Subpart F). DOE Order 5820.2, which deals with radioactive waste management, is also covered under the 5400.1 requirements. The groundwater monitoring requirements for

DOE established the Hanford Groundwater Monitoring Project to manage monitoring for a variety of state and federal requirements. The main objectives of the project are to track contaminant plumes and to detect any new contamination from former or active waste sites. federal and state regulations are presented in Sections 2.4 and 2.5 of this document.

Because of the Hanford Site's unique groundwater pollution problems, radiation protection of the public and the environment is an integral part of the Hanford Groundwater Monitoring Project. The requirements for radiation management are found in DOE Order 5820.2, established to satisfy the groundwater monitoring objectives listed in Section 2.0. The objectives of the DOE orders regarding groundwater monitoring include the following:

- verify compliance with other applicable regulations

- characterize and define hydrogeologic, physical, and chemical trends in the groundwater system

- establish groundwater quality baselines

- provide continuing assessment of monitoring and remediation activities

- identify new and quantify existing groundwater contamination and quality problems.

The groundwater project assesses the impact of radionuclides and other hazardous effluents from nonRCRA facilities on groundwater quality. In addition, the project monitors and documents the overall distribution and movement of radionuclides and other hazardous contaminants in groundwater beneath and adjacent to the Hanford Site in accordance with DOE Orders 5400.1 and 5400.5 .

\subsubsection{Radiation Protection of the Public and the Environment}

DOE Order 5400.5 establishes standards and requirements for DOE and its contractors to operate the facilities and conduct the activities so that radiation exposure to the public is maintained within the limits described in the order (e.g., public dose limits and derived concentration guides for air and water). The standards also aim to control radioactive contamination through the management of real and personal property. In addition, it is DOE's objective to protect the environment from radioactive contamination to the extent practical. 


\subsection{Hanford Federal Facility Agreement and Consent Order}

The Tri-Party Agreement (Ecology et al. 1989) is a key element governing activities at the Hanford Site. Compliance timetables, waste cleanup timetables, and implementation milestones are established in the TriParty Agreement to ensure that cleanup progresses and to enforce environmental protection. Tri-Party

The Tri-Party Agreement provides the legal and procedural basis for cleanup of hazardous waste sites on the Hanford Site. It is the vehicle that coordinates groundwater monitoring and remediation activities under RCRA and CERCLA.

Agreement Milestone M-13-81A established DOE/ RL-89-12, Rev. 2 as the vehicle to coordinate groundwater protection and remedial action efforts and to manage Hanford Site groundwater. The Tri-Party Agreement is a contract between the U.S. Environmental Protection Agency (EPA), Washington State Department of Ecology (Ecology), and DOE to achieve compliance (enforceable by law) with the remedial action provisions of CERCLA and the TSD unit regulation and corrective-action provisions of RCRA.

This document contains the results of applicable groundwater protection, cleanup; and monitoring activities as scheduled in the Tri-Party Agreement action plan. Table 2.1 provides a general listing of the major milestones. Details for each milestone are described in the Tri-Party Agreement.

\subsection{Applicable Federal Regulations}

This section describes the federal regulations that govern groundwater monitoring, remedial investigation, and remediation. The integration of the institutional and regulatory requirements are defined by the Tri-Party Agreement (Ecology et al. 1989) and are outlined in Section 2.6.

\subsubsection{Comprehensive Environmental Response, Compensation, and Liability Act of 1980/Superfund Amendments and Reauthorization Act of 1986}

These acts establish a federal program that authorizes waste cleanup at inactive waste sites. The Hanford Site was listed on the National Priorities List (Appendix B of 40 CFR 300) based on the EPA's hazard ranking system that subdivided the Hanford Site into four National Priorities List sites: 100, 200, 300, and 1100 areas. Preliminary assessments revealed $\sim 1,400$ sites where hazardous substances may have been disposed. These four sites were further divided into 74 source and 10 groundwater operable units (i.e., a grouping of individual waste units based primarily on geographic area and common waste sources).

The groundwater operable units currently being studied were selected as a result of Tri-Party Agreement negotiations (Ecology et al. 1989). Table 2.2 defines the current status of groundwater operable unit monitoring according to Tri-Party Agreement priority, and also defines the Tri-Party Agreement

The Comprehensive Environmental Response, Compensation, and Liability Act of 1980 regulates cleanup of inactive waste sites. At Hanford, 1,400 of these sites have been grouped into 74 "operable units" based on geographic area and common waste sources.

regulatory unit designation and the regulatory agency responsible for the operable unit (described more fully in Section 2.6).

The Hanford Past-Practices Strategy (DOE/ RL-91-40) provides the framework to streamline corrective actions through the use of limited field investigations, expedited response actions, and interim remedial measures. The bias-for-action principles of the strategy were pursued vigorously to accelerate the 
groundwater remediation project through the investigative phases and into pilot-scale treatability studies. Both the investigative phases and the pilot studies gathered important data necessary to begin full-scale remediation activities through implementation of interim remedial measures.

The Hanford Future Site Users Group has recommended that the water beneath the 200 Areas plateau be excluded from use and managed to limit or restrict access by the public. DOE, EPA, and the Washington State Department of Ecology support this recommendation.

The interim actions consist primarily of hydraulic containment actions using pump-and-treat technologies. These actions are designed to halt the continued migration of the most contaminated portions of the groundwater into the Columbia River or out of aquifers underlying the 100 and 200 areas. DOE plans to continue the interim remedial measures already under way and to supplement and expand the system, where needed, to meet remediation objectives.

The Hanford Sitewide Groundwater Remediation Strategy (DOE/RL-94-95, Rev. 1) establishes an overall goal of restoring groundwater to its beneficial uses to protect human health and the environment and its use as a natural resource. In recognition of the Hanford Future Site Uses Working Group (Drummond 1992) and public values, the strategy establishes that the site-wide approach to groundwater cleanup is to remediate the major plumes found in the reactor areas and to contain the spread and reduce the mass of the major plumes found in the 200 Areas. This remediation strategy is documented in DOE/RL-89-12, Rev. 2 and DOE/RL-94-95, Rev. 1.

Groundwater monitoring is performed at operable units to evaluate the remediation activities or to monitor contaminants in areas where there is no active groundwater remediation. Individual requirements as defined by CERCLA are described in the work plans and/or records of decision. See Table 2.2 for the operable units that are currently monitored.

Under the EPA's interpretation of CERCLA, contaminated groundwater generally must be cleaned up to meet maximum contaminant levels or goals established under the Safe Drinking Water Act of 1974 if the groundwater, prior to contamination, could have been used as a drinking water source. Using the EPA's groundwater classification as well as Ecology's highest beneficial use assumption in Washington Administrative Code (WAC) 173-340-720, almost all Hanford Site groundwater is, by definition, a potential future source of drinking water. The classification is based on the quality characteristics of the groundwater and not those related to land-use designations, which are tied to the source or surface operable unit remediation. These cleanup levels are identified in the applicable operable unit's record of decision (e.g., ROD $1995,1996 \mathrm{a}, 1996 \mathrm{~b}, 1997)$ or action memorandum (e.g., Ecology and EPA 1994).

Certain areas of the Hanford Site may require restrictions to groundwater use. The Hanford Future Site Uses Working Group, supported by DOE, Ecology, and EPA, recognizes that contaminated soil and groundwater beneath the 200 Areas plateau will be difficult to clean up and cleanup levels/requirements may not be achieved. The group has recommended that the water beneath the 200 Areas plateau be excluded from use and managed to limit or restrict access by the public (Drummond 1992).

\subsubsection{Resource Conservation and Recovery Act of 1976}

Regulatory standards for the generation, transportation, storage, treatment, and disposal of hazardous waste are established in RCRA. The standards relate to ongoing waste management and obtaining operating permits for those facilities. Ecology and EPA designated the Hanford Site as a single RCRA facility with over 60 individual liquid and solid waste TSD units. The Tri-Party Agreement (Ecology et al. 1989) 
recognized that all of the TSD units could not obtain permits simultaneously. It set up a schedule to submit unit-specific Part B, RCRA/dangerous waste permit applications and closure plans to Ecology and EPA. Twenty-five TSD waste management areas require groundwater monitoring to determine the impact operations have on the uppermost aquifer or to assess the nature, extent, and rate of contaminant migration.

The Resource Conservation and Recovery Act of 1976 establishes regulatory standards for the generation, transportation, storage, treatment, and disposal of hazardous waste. There are 60 RCRA units on the Hanford Site, and 25 of them require groundwater monitoring.

The RCRA groundwater monitoring requirements for the 25 active waste management areas fall into one of two categories: interim status or final status. A permitted or closed RCRA TSD unit requires final status groundwater monitoring as specified in $40 \mathrm{CFR} 264$. Non-permitted RCRA units require interim status groundwater monitoring as specified in 40 CFR 265. EPA authorized Ecology to implement its dangerous waste program in lieu of the EPA's program. Ecology's interim status TSD requirements, established in WAC 173-303-400, invoke 40 CFR 265 that governs RCRA groundwater monitoring activities. RCRA final status TSD sites follow WAC 173-303-645, which specifies the groundwater monitoring requirements. Results of RCRA monitoring are discussed in the annual groundwater report.

The annual report also includes groundwater results for the Environmental Restoration Disposal Facility. This facility is a landfill authorized under CERCLA that is constructed to meet final status RCRA technical requirements (40 CFR 264). The facility is not a RCRA TSD unit but utilizes a four well, RCRA-style, groundwater monitoring network and conducts monitoring in accordance with WAC 173-303-645 as outlined in BHI-00079.
RCRA groundwater monitoring is conducted under one of three possible phases:

- indicator parameter/detection. Initially, a detection program is developed to determine and monitor the impact of facility operations on the groundwater.

- assessment (or final status compliance). If the detection monitoring results indicate a statistical increase in the concentration of dangerous waste in the groundwater, then an assessment (or final status compliance) phase of monitoring and investigation is initiated.

- corrective action (via administrative order [for interim status sites] or during final status). If the source of the contamination is determined to be the TSD unit and the concentration exceeds the maximum concentration limits as defined in the monitoring program plan or permit, then Ecology may require corrective action to reduce the contaminant hazards to the public and environment.

\section{RCRA Monitoring}

- The RCRA Groundwater monitoring requirements fall into one of two categories: interim status or final status.

- Permitted or closed RCRA sites require final status groundwater monitoring.

- Non-permitted RCRA sites require interim status groundwater monitoring.

- A permitted RCRA site is one that will continue to receive hazardous waste under a state permit.

- A non-permitted RCRA site no longer receives waste and will be closed. 
The comparisons and details of these three phases of groundwater monitoring and the specific requirements of the interim and final status groundwater monitoring projects are provided in Section 7.0.

\subsection{Applicable State Regulations}

\subsubsection{Dangerous Waste Regulations}

As stated in Section 2.4.2, EPA authorized Ecology to implement state groundwater regulations. WAC $173-303-400$ and -600 provide the requirements for interim and final status TSD units. The state interim status regulations invoke the EPA regulations (40 CFR 265) that govern the RCRA groundwater monitoring activities. RCRA final status TSD units follow WAC 173-303-645, which specifies the groundwater monitoring requirements for operating or closed facilities.

\subsubsection{State Waste Discharge Program}

Non-RCRA TSD units are regulated by DOE orders and the Tri-Party Agreement (Ecology et al. 1989). These consist primarily of soil-column-disposal facilities that received treated effluent from liquid waste that was associated with nuclear material processing, refining, and waste-treatment activities. An agreement was reached in December 1991 to regulate these non-RCRA TSD units and to include all miscellaneous

In addition to administrating $R C R A$, the Washington State Department of Ecology regulates non-RCRA disposal facilities on the Hanford Site. Four of these sites require groundwater monitoring.

waste streams and/or any new waste streams discharged to the groundwater under the waste discharge permit system defined in WAC 173-216. All major discharges of untreated wastewater were terminated in June 1995.

Groundwater monitoring is conducted at three of the WAC 173-216 permit sites: $4608 \mathrm{~B} / \mathrm{C}$ ponds (also called the 400 Area process ponds), 200 Areas Treated Effluent Disposal Facility, and the 616-A crib (also called State-Approved Land Disposal Site or SALDS) (Ecology 1995a, 1995b, 1996a). The State-Approved Land Disposal Site receives treated effluent from the 200 Areas Effluent Treatment Facility. Monitoring and reporting requirements for the latter two facilities are specified in the monitoring plans (DOE/RL-89-12, Rev 2; WHC-SD-C018H-PLN-004, Rev. 1).

\subsubsection{Minimum Functional Standards for Solid Waste Handling}

The Solid Waste Landfill is a disposal facility that is not a RCRA hazardous waste site and is not addressed under the Tri-Party Agreement (Ecology et al. 1989). WAC 173-304 regulates the current operation of this landfill. A permit application was submitted to the Benton-Franklin District Health Department in 1991 (DOE/RL-90-38, Rev. 0). Responsibility for the site was subsequently assumed by Ecology (DOE/RL-90-38, Rev. 1). Groundwater monitoring conducted at this landfill complies with requirements stipulated in WAC 173-304-490. WAC 173-304 requires that data for specific groundwater parameters be reported annually. This requirement is fulfilled by the data and interpretations included in this report.

\subsubsection{Model Toxics Control Act - Cleanup}

Through WAC 173-340, Ecology defined standards that govern the decisions for hazardous waste cleanup. These standards are designed to direct and expedite cleanup at hazardous waste sites that come under the scope of the Superfund Amendments and Reauthorization Act of 1986 and under RCRA corrective action responsibilities. The funding for this type of waste cleanup is through a state tax on disposal of hazardous substances.

\subsection{Regulatory Authority Interface}

\subsubsection{Regulatory Programs}

The RCRA, CERCLA, WAC regulations and $D O E$ orders overlap in many areas with respect to 
groundwater monitoring, remedial investigations, and remediation. The following sections clarify how, through the Tri-Party Agreement (Ecology et al. 1989), these programs must interface to achieve integration and to minimize redundancy during implementation of groundwater projects.

Ecology and EPA selected a lead regulatory agency approach to minimize duplication of effort and to maximize productivity. Either EPA or Ecology will be the lead regulatory agency for each operable unit, TSD group/unit, or milestone. The regulatory agency currently assigned the lead for each groundwater operable unit is listed in Table 2.2.

\subsubsection{Waste Unit Categories}

There are three waste unit categories and related regulatory authorities addressed in the Tri-Party Agreement action plan: RCRA TSD, RCRA past-practice, and CERCLA past-practice.

TSD units are defined as units receiving a RCRA permit for either operation or postclosure care and must be closed to meet WAC 173-303-610 and the Hazardous and Solid Waste Amendments of 1984. The permits based on the nature of waste and timing of disposal. TSD units that require groundwater monitoring shall remain classified as RCRA units, rather than CERCLA units, even if they are investigated in conjunction with CERCLA units. All TSD units that undergo closure, irrespective of permit status, must be closed pursuant to the authorized regulations in WAC 173-303-610.

The RCRA and CERCLA past-practice units are waste management units where hazardous substances from sources other than TSD units have been disposed, as addressed by CERCLA, regardless of date of receipt at the units.

\subsubsection{Management of Waste Management Units}

Since the Hanford Site was placed on the National Priorities List (Appendix B of 40 CFR 300), Ecology,
EPA, and DOE agreed that the units managed as RCRA past-practice units shall address all CERCLA hazardous substances for the purposes of corrective action. An agreement also was made that all of the waste regulated by WAC 173-303 (i.e., RCRA) will be addressed as part of any CERCLA response action or RCRA corrective action.

Section 121 of CERCLA requires that remedial actions attain a degree of cleanup that meets applicable federal and state environmental requirements. Based on this, the Tri-Party Agreement (Ecology et al. 1989 ) requires that (1) all state-only hazardous waste will be addressed under CERCLA and (2) RCRA standards for cleanup or TSD requirements will be met under a CERCLA action. This eliminates many discrepancies between the two programs and lessens the significance of whether an operable unit is placed in one program or the other.

All inactive units within an operable unit are designated as either RCRA or CERCLA past-practice.' This designation ensures that only one past-practice program is applied at each operable unit. The corrective action process selected for each operable unit must be sufficiently comprehensive to satisfy the technical requirements of both statutory authorities and the respective regulations.

The authority in CERCLA will be used for operable units that consist primarily of past-practice units (i.e., no TSD units). The CERCLA authority also will be used for past-practice units in which remediation of CERCLA-only materials is the majority of work to be done in that operable unit. The RCRA past-practice authority generally is used for operable units that contain significant TSD units and/or lowerpriority past-practice units. Currently assigned RCRA and CERCLA past-practice designations were shown in Table 2.2.

\subsubsection{Waste Unit Interface}

There are several cases when TSD units are closely associated with past-practice units, both geographically or through similar processes and waste streams. 
To economically and efficiently address the contamination, a procedure to coordinate the TSD unit closure or permitting activity with the past-practice investigation and remediation activity is necessary to prevent overlap and duplication of work. Based on the discussion in Section 2.6.3, selected TSD groups/units were

Some waste sites are regulated by both RCRA and CERCLA. At these sites, RCRA closure is coordinated with CERCLA cleanup.

assigned to corresponding operable units. The information necessary to perform RCRA closure/postclosure within an operable unit is provided in various RCRA facility investigation/corrective measure reports. The initial work plan contains a sampling and analysis plan for the associated RCRA units. It outlines the manner in which RCRA closure/postclosure requirements are met in the work plan and subsequent documents. The selected closure/postclosure method and associated design details, submitted as part of the corrective measure report, must (1) meet RCRA standards and requirements, (2) be consistent with requirements specified in the sitewide RCRA permit (Ecology 1994), and (3) be coordinated with the recommended remedial action for the associated operable unit. Each remedial facility investigation and corrective measure document must be structured such that RCRA closure/ postclosure requirements can be readily identified for a separate review and approval process and so the RCRA closure/postclosure requirements can be incorporated into the RCRA permit.

Ecology, EPA, and DOE agreed that past-practice authority may provide the most efficient means to deal with contamination plumes of mixed waste that originated from a combination of TSD and pastpractice units. However, to ensure that TSD units within the operable units comply with RCRA and state hazardous waste regulations, Ecology intends that all corrective actions, excluding situations where there is an imminent threat to the public health or environment, will be conducted to ensure compliance with the technical requirements of the Revised Code of Washington 70.105, Hazardous Waste Management. . The DOE Richland Operations Office assigned the maintenance of RCRA and state groundwater monitoring compliance at TSD units within the operable units to the groundwater project. 
Table 2.1. Management Requirements

\author{
Hanford Site \\ Groundwater Program
}

$$
\begin{gathered}
\text { Tri-Party Agreement (TPA) } \\
\text { Milestones }^{(\mathrm{a})}
\end{gathered}
$$

Regulations/Orders

\section{Resource Conservation and Recovery Act of 1976 (RCRA)}

RCRA/TSD unit monitoring
40 CFR 264

40 CFR 265

40 CFR 257

WAC $173-303-400,-645$
CERCLA operable unit remedial assessment monitoring

Site-wide environmental surveillance and operational monitoring

Facility-specific monitoring

State-Approved Land

Disposal Site

200 Areas Treated Effluent

Disposal Facility

400 Area process ponds
M-15-00

M-16-00

\section{Atomic Energy Act of 1954}

DOE Orders 5400.1, 5400.5, and 5820.2

\section{Liquid Effluent Disposal Facilities}

$$
\text { M-17-00b }
$$

WAC $173-216$

SWDP Permit ST-4500(b)

SWDP Permit ST-4502(b)

WAC $173-216$

SWDP Permit ST-4501 ${ }^{\text {(b) }}$

(a) TPA M-20-00 - Submit Part B permit applications or closure/postclosure plans for all RCRA TSD units.

TPA M-24-00 - Install RCRA groundwater monitoring wells at the rate of up to 50/year (after 1990) as scheduled in interim milestones until all land disposal units and single-shell tanks are determined to have RCRA-compliant monitoring systems.

TPA M-15-00 - Complete remedial investigation/feasibility study (or RCRA facility investigation/corrective measure study) process for all operable units.

TPA M-16-00 - Complete remedial actions for all non-tank farm operable units.

TPA M-17-00b - Complete implementation of best available technology/all known available and reasonable methods of prevention, control, and treatment for all Phase II liquid effluent streams at the Hanford Site.

(b) Ecology (1995b, 1995a, 1996a, respectively).

CFR = Code of Federal Regulations.

$\mathrm{DOE} \quad=$ U.S. Department of Energy.

SWDP = State Waste Discharge Permit.

TSD = Treatment, storage, and disposal (units).

WAC = Washington Administrative Code. 
Table 2.2. Groundwater Operable Unit Monitoring Status

\begin{tabular}{|c|c|c|c|c|}
\hline $\begin{array}{l}\text { Tri-Party } \\
\text { Agreement } \\
\text { Priority }\end{array}$ & $\begin{array}{l}\text { Groundwater } \\
\text { Operable Unit }\end{array}$ & Monitoring Status & $\begin{array}{l}\text { Regulatory Unit } \\
\text { Designation }\end{array}$ & $\begin{array}{l}\text { Lead Regulatory } \\
\text { Agency }\end{array}$ \\
\hline 1 & 1100-EM-1 & Contaminant monitoring & CERCLA past practice & EPA \\
\hline $2 \mathrm{~A}$ & $300-\mathrm{FF}-5$ & Contaminant monitoring & CERCLA past practice & EPA \\
\hline $4 \mathrm{~A}$ & 100-HR-3 & $\begin{array}{l}\text { Performance monitoring for } \\
\text { pump-and-treat interim action }\end{array}$ & RCRA past practice & Ecology \\
\hline $6 \mathrm{~A}$ & $100-\mathrm{BC}-5$ & Contaminant monitoring & CERCLA past practice & EPA \\
\hline $7 \mathrm{~A}$ & $100-\mathrm{KR}-4$ & $\begin{array}{l}\text { Performance monitoring for } \\
\text { pump-and-treat interim action }\end{array}$ & CERCLA past practice & EPA \\
\hline 9 & 100-NR-2 & $\begin{array}{l}\text { Performance monitoring for } \\
\text { pump-and-treat interim action }\end{array}$ & RCRA past practice & Ecology \\
\hline $10 \mathrm{~A}$ & 100-FR-3 & Contaminant monitoring & CERCLA past practice & EPA \\
\hline 13 & $200-\mathrm{BP}-5$ & Contaminant monitoring & CERCLA past practice & EPA \\
\hline $20 \mathrm{~A}$ & 200-UP-1 & $\begin{array}{l}\text { Performance monitoring for } \\
\text { pump-and-treat interim action }\end{array}$ & RCRA past practice & Ecology \\
\hline $20 \mathrm{~A}$ & $200-Z P-1$ & $\begin{array}{l}\text { Performance monitoring for } \\
\text { pump-and-treat interim action }\end{array}$ & CERCLA past practice & EPA \\
\hline $20 \mathrm{~B}$ & 200-PO-1 & Contaminant monitoring & RCRA past practice & Ecology \\
\hline
\end{tabular}

(a) Listed from highest to lowest.

CERCLA = Comprehensive Environmental Response, Compensation, and Liability Act of 1980.

Ecology $=$ Washington State Department of Ecology.

EPA = U.S. Environmental Protection Agency.

RCRA $=$ Resource Conservation and Recovery Act of 1976. 


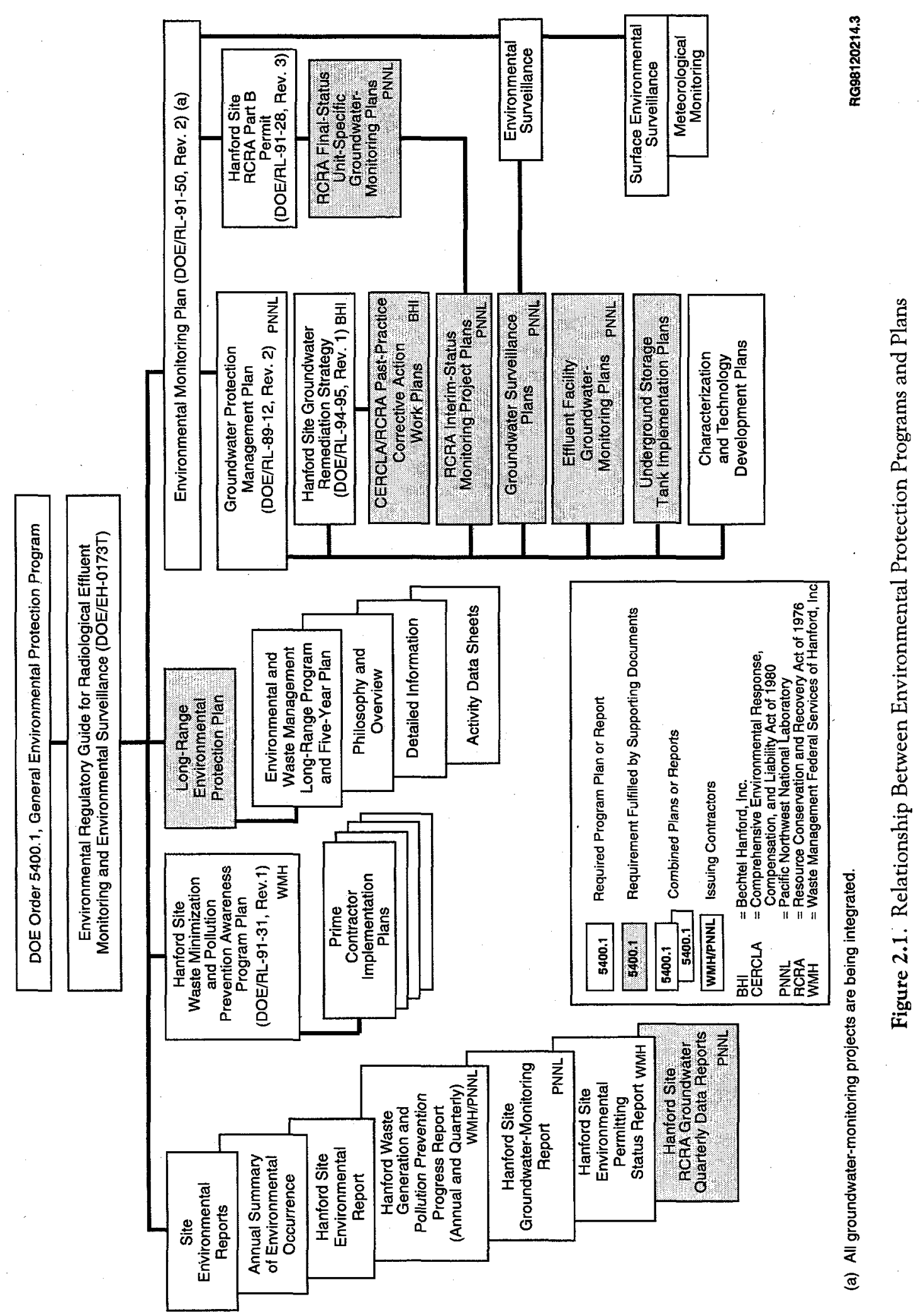


-
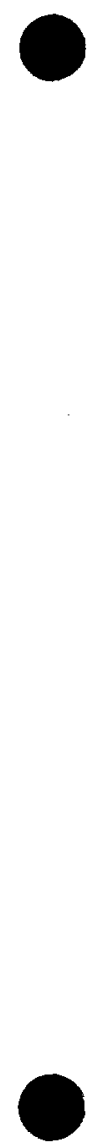


\subsection{Hydrogeologic Setting}

The groundwater flow system affects the potential for contaminants to migrate from the Hanford Site through the groundwater pathway. To understand this system, the geology and hydrology of the site must be determined because they control the movement of contaminants in groundwater. The hydrogeologic information also is used to determine the design and location of monitoring wells. This information provides the basis for numerical modeling of groundwater. flow and contaminant plume migration. This section provides an overview of the hydrogeology of the Hanford Site and describes groundwater flow within the unconfined aquifer.

\subsection{Geologic Setting}

The Hanford Site lies in the Columbia Plateau, a broad plain situated between the Cascade Range to the west and the Rocky Mountains to the east. The Columbia Plateau was formed by a thick sequence of Miocene-Age tholeiitic basalt flows, called the Columbia River Basalt Group, that erupted from fissures in northcentral and northeastern Oregon, eastern Washington, and western Idaho (Swanson et al. 1979). The Columbia Plateau is often called the Columbia Basin because it forms a broad lowland surrounded by mountains. In the central and western sections of the Columbia Plateau, where the Hanford Site is located, the Columbia River Basalt Group is underlain by continental sedimentary rocks from earlier in the Tertiary Period.

The basalt and sedimentary rocks have been folded and faulted over the past 17 million years, creating broad structural and topographic basins separated by asymmetric anticlinal ridges. Sediment up to 518 meters thick accumulated in some of these basins. Basalt flows are exposed along the anticlinal ridges, where they have been uplifted as much as 1,097 meters above the surrounding area. Overlying the basalts in the synclinal basins is sediment from the late Miocene, Pliocene, and Pleistocene Ages. The Hanford Site lies within one of the larger basins, the Pasco Basin, that is bounded on the north by the Saddle Mountains and on the south by Rattlesnake Mountain and the Rattlesnake Hills. The Yakima and Umtanum ridges extend into the basin and subdivide it into a series of anticlinal ridges and synclinal basins. The largest syncline, the Cold Creek syncline, lies between Umtanum and Yakima ridges and is the principal structural basin containing DOE's waste management areas. Figure 3.1 shows the surface geology and major structural features of the Pasco Basin. The geology of the Hanford Site is described in detail in DOE/RW-0164.

The Hanford Site lies in the Columbia Plateau. There are a minimum of 50 basalt flows beneath the Hanford Site. Sandwiched between these basalt flows are the sedimentary interbeds consisting of mud, sand, and gravel deposited between volcanic eruptions. The basalt flows are overlain with sediment from the Ringold and Hanford formations.

The stratigraphic units underlying the Hanford Site include, in ascending order, the Columbia River Basalt Group, Ringold Formation, Plio-Pleistocene unit (including the early Palouse soil), and Hanford formation (Figure 3.2). A discontinuous veneer of Holocene alluvium, colluvium, and/or eolian sediment overlies the principal geologic units. The hydrogeologic and geologic stratigraphic columns in Figure 3.2 show differences in stratigraphy, primarily within the Hanford and Ringold formations. The geologic column on the right defines the lithostratigraphic units, based on mapping and physical properties of the sediment, modified from BHI-00184. The hydrogeologic column on the left defines hydrostratigraphic units based on 
hydraulic properties (PNL-8971). The various stratigraphic units found within the Hanford Site boundaries are described in the following sections.

\subsubsection{Columbia River Basalt Group}

There are a minimum of 50 basalt flows beneath the Hanford Site with a combined thickness of more than 3,000 meters (DOE/RW-0164). The most recent basalt flow underlying the Hanford Site is the Elephant Mountain Member of the Saddle Mountains Basalt. However, the younger Ice Harbor Member is found in the southern part of the site (DOE/RW-0164). Sandwiched between various basalt flows are sedimentary interbeds, collectively called the Ellensburg Formation, which include fluvial and lacustrine sediment consisting of mud, sand, and gravel deposited between volcanic eruptions. Along with the porous basalt flow tops and bottoms, these sediments form basalt-confined aquifers that extend across the Pasco Basin. The Rattlesnake Ridge interbed is the uppermost laterally extensive hydrogeologic unit of these sedimentary interbeds.

\subsubsection{Ringold Formation}

The Pliocene-Age Ringold Formation sediment overlies the basalts and is overlain by late Plioceneand Pleistocene-Age deposits. Ringold Formation sediment consists of a heterogeneous mix of variably cemented and compacted gravel, sand, silt, and clay deposited by the ancestral Columbia and Snake Rivers (Fecht et al. 1987; Reidel et al. 1994; WHC-SD-ENEE-004). The system that deposited the sediment was a braided stream channel with the two rivers joining in the area of the present White Bluffs. The deposits at the Hanford Site represent an eastward shift of the Columbia River from the west side of the Hanford Site to the east side. The Columbia River first flowed across the west side of the Hanford Site (where Dry Creek is now), crossing through the Rattlesnake Hills. The river eventually shifted to a course that took it through the gap between Gable Mountain and Gable Butte and south across the present 200 East Area.
Traditionally, the Ringold Formation in the Pasco Basin is divided into several informal units. In ascending order, these units are the (1) gravel, sand, and paleosols of the basal unit; (2) clay and silt of the lower unit; (3) sand and gravel of the middle unit; (4) mud and lesser sand of the upper unit; and (5) basaltic detritus of the fanglomerate unit (DOE/RW-0164, Newcomb 1958, Newcomb et al. 1972, RHO-BWIST-4, RHO-ST-23, SD-BWI-DP-039). Ringold strata also have been divided on the basis of facies types (RHO-BWI-ST-14) and fining upward sequences (Puget Sound Power and Light Company 1982). The Ringold sediment facies have been described on the basis of lithology, stratification, and pedogenic alteration (WHC-SD-EN-TI-012, BHI-00184). More recently, the facies types identified include the following:

- fluvial gravel facies - These consist of matrixsupported granule to cobble gravels with a sandy silt matrix and intercalated sands and muds. The facies were deposited in a gravelly fluvial braid plain characterized by wide, shallow, shifting channels.

The Ringold Formation consists of layers of gravel, sand, silt, and clay, deposited by the ancestral Columbia and Snake Rivers.

- fluvial sand facies - These consist of cross-bedded and cross-laminated sands that are intercalated with lenticular silty sands, clays, and thin gravels. Fining upward sequences are common. Strata comprising the association were deposited in wide, shallow channels.

- overbank facies - These consist of laminated to massive silt, silty fine-grained sand, and paleosols containing variable amounts of pedogenic calcium carbonate. Overbank deposits occur as thin lenticular interbeds in the gravels and sands and as thick, laterally continuous sequences. These sediments record deposition in proximal levee to more distal floodplain conditions. 
- lacustrine facies - These are characterized by plane laminated to massive clay with thin silt and silty sand interbeds displaying some soft sediment deformation. Deposits coarsen downward. Strata were deposited in a lake under standing water to deltaic conditions.

- alluvial fan facies - These are characterized by massive to crudely stratified, weathered to unweathered basaltic detritus. These deposits generally are found around the periphery of the basin and record deposition by debris flows in alluvial fan settings and in sidestreams draining into the Pasco Basin.

As described and illustrated in the geologic column on the right side of Figure 3.2, the upper part of the Ringold Formation is composed of interbedded fluvial sand and overbank facies, which are overlain by mud-dominated lacustrine facies (BHI-00184, WHC-SD-EN-EE-004). The lower part of the Ringold Formation contains five separate stratigraphic intervals dominated by the fluvial gravel facies. These gravels, designated Units $A, B, C, D$, and $E$, are separated by intervals containing deposits typical of the overbank and lacustrine facies. The lowermost of the fine-grained sequence units, overlying Unit $A$, is designated the lower mud sequence. The lithofacies defined in WHC-SD-EN-EE-004 were regrouped into nine hydrogeologic units to support development of a layered, three-dimensional, groundwater flow and transport model (PNL-8971, PNL-10195, PNL-10886). A comparison of these units with the stratigraphic column of BHI-00184 is shown in Figure 3.2.

\subsubsection{Plio-Pleistocene Unit and Early Palouse Soil}

The laterally discontinuous Plio-Pleistocene unit overlies the Ringold Formation and is found only in the western part of the Hanford Site (DOE/RW-0164). This unit consists of sidestream alluvial deposits and buried soil horizons with significant caliche in some areas and is generally above the current water table (Slate 1996).
The Pleistocene-Aged early Palouse soil is a buried eolian unit that overlies part of the Plio-Pleistocene unit. Because of the difficulty in distinguishing the early Palouse soil from the Plio-Pleistocene unit, these two are commonly grouped together and called the Plio-Pleistocene unit. The early Palouse soil consists of up to 20 meters of massive, brown-yellow, and compact, loess-like silt and minor fine-grained sand (DOE/ RW-0164, RHO-ST-23). The early Palouse soil is found only in the vicinity of the 200 West Area. The early Palouse soil and the fine-grained and caliche portions of the Plio-Pleistocene unit, both of which are found in the 200 West Area, form a low-permeability layer that affects migration of water through the vadose zone.

\subsubsection{Hanford Formation and Pre- Missoula Gravels}

The informally named Hanford formation consists of deposits from a series of cataclysmic floods during the Pleistocene Age. The floods occurred when ice dams broke, releasing water from Lake Missoula, a large glacial lake that formed in the Clark Fork River valley. Flood episodes may have occurred as many as 40 times, with the released water spreading across eastern Washington. The floodwaters collected in the Pasco Basin and formed Lake Lewis, which is estimated to have drained in about a week through the gap in the Horse Heaven Hills called Wallula Gap (Allison 1933). Three principal types of deposits were left behind by the floods: (1) high-energy deposits, consisting of gravel; (2) low-energy, slackwater deposits, consisting of rhythmically bedded silt and sand of the Touchet Beds; and (3) coarse- to fine-sand deposits, representing an energy transition environment. Fluvial pre-Missoula (flood) gravels underlie the Hanford formation gravel deposits in the central part of the Hanford Site. The pre-Missoula deposits are difficult to distinguish from the Hanford gravels, so they are usually grouped together.

The Hanford formation is divided into a variety of sediment types, facies, or lithologic packages. Reports 
dealing with the Hanford formation (WHC-MR-0391, WHC-SD-EN-EE-004) recognized three basic facies: gravel, sand, and silt dominated. These facies generally correspond to the coarse gravels, laminated sands, and graded rhythmites, respectively (Baker et al. 1991, DOE/RW-0164, WHC-SD-ER-TI-003). The Hanford formation ranges in thickness from less than 1 meter to greater than 100 meters.

Gravel-dominated strata consist of coarse-grained sand and granule to boulder gravel that display massive bedding, plane to low-angle bedding, and largescale cross-bedding in outcrop. Matrix commonly is lacking from the gravels, giving them an open framework appearance. The sand-dominated facies consists of fine- to coarse-grained sand and granules that display plane lamination and bedding and, less commonly, plane and trough cross-bedding in outcrop. Small pebbles and pebbly interbeds (less than 20 centimeters thick) may be encountered. The silt-dominated facies consists of silt and fine- to coarse-grained sand that form normally graded rhythmites. Plane lamination and ripple cross-lamination are common in outcrop.

The Hanford formation was deposited by a series of cataclysmic floods during the Pleistocene Age. The sediment is commonly coarse-grained, ranging from sand to cobble and boulder size gravel.

The water table lies within the Hanford formation over most of the eastern and northern parts of the Hanford Site (Figure 3.3). The Hanford formation lies entirely above the water table in the western part of the site and in some other localized areas. Figure 3.4 shows a geologic cross-section of the Hanford Site and the location of the water table between Cold Creek Valley and the Columbia River. This cross-section represents $A-A^{\prime}$ 'on the map in Figure 3.3 and shows that the saturated sediment of the Hanford formation represents a small portion of the total saturated sediment above basalt.

\subsubsection{Holocene Surficial Deposits}

Holocene surficial deposits, consisting of silt, sand, and gravel, form a thin veneer (less than 5 meters) across much of the Hanford Site. In the 200 West Area and southern part of the 200 East Area, these deposits consist dominantly of laterally discontinuous sheets of wind-blown silt and fine-grained sand. They are generally found above the water table.

\subsection{Hydrologic Setting}

This section provides general information on groundwater flow under the Hanford Site. Additional details concerning hydrogeologic conditions at each of the RCRA sites is provided in Section 4.0.

Groundwater is present in both unconfined and confined aquifers at the Hanford Site. The unconfined aquifer is contained in the unconsolidated to semiconsolidated Ringold and Hanford formations that overlie the basalt bedrock. In some areas, lowpermeability mud layers form aquitards that create confined hydraulic conditions in the underlying sediment. The aquifers contained in the suprabasalt sediment is referred to as the Hanford/Ringold aquifer system in this report. The following discussion focuses on the Hanford/Ringold aquifer system because, as the uppermost system, it is most likely to be affected by contaminants released from Hanford Site sources. From a local perspective, the unconfined aquifer is referred to as the saturated zone above low-permeability mud units for some areas (e.g., 200 West Area and most of the 100 Areas).

The saturated thickness of the Hanford/Ringold aquifer system is greater than 180 meters in areas near the Central Landfill, west of the 200 West Area, and north of Gable Butte near the $100 \mathrm{~B} / \mathrm{C}$ and $100 \mathrm{~K}$ areas, but pinches out along the flanks of the basalt ridges. Depth to the water table ranges from less than 1 meter near the Columbia River to more than 100 meters near the 200 Areas. Perched water-table conditions have been encountered in sediment above the 
Hanford/Ringold aquifer system in the 200 West Area (PNL-8597, WHC-MR-0206) and in irrigated areas east of the Columbia River (RHO-BWI-C-56).

A sequence of basalt-confined aquifers is present within the Columbia River Basalt Group beneath the Hanford Site. These aquifers are composed of sedimentary interbeds and the relatively permeable tops of

Groundwater is present in both unconfined and confined aquifers at the Hanford Site. A confined aquifer is bounded above and below by sediment or rock with low permeability. An unconfined aquifer is not overlain by an impermeable unit; its top is the water table.

On the Hanford Site, the unconfined aquifer is contained in the Ringold and Hanford formations. Groundwater in this aquifer flows toward, and discharges to, the Columbia River.

basalt flows. The dense interior sections of the basalt flows form confining layers. Groundwater in the basaltconfined aquifers generally flows from elevated regions at the edge of the Pasco Basin toward the Columbia River (PNL-10817). However, the discharge zone locations are also influenced by geologic structures that increase the vertical permeability of the confining basalt layers. Additional information on the upper basalt-confined aquifer system is available in DOE/ RW-0164, PNL-10158, and PNL-10817.

\subsubsection{Recharge and Discharge}

Natural recharge to the Hanford/Ringold aquifer system occurs due to

- infiltration of runoff from elevated regions along the western boundary of the Hanford Site

- infiltration of spring water and upwelling of groundwater that originates from the basalt-confined aquifer system
- infiltration of precipitation falling across the Hanford Site.

Some recharge also takes place along the Yakima River. Recharge from precipitation is highly variable, both spatially and temporally. It ranges from near zero to greater than 100 millimeters per year, depending on climate, vegetation, and soil texture (Gee et al. 1992, PNL-10285). Recharge from precipitation is highest in coarse-textured soil with little or no vegetation, which is the case for most of the industrial areas on the Hanford Site. Figure 3.5 shows the estimated average natural recharge based on distributions of soil and vegetation types. Some artificial recharge as a result of irrigation occurs in the upper Cold Creek Valley in the western part of the site and in agricultural areas south of the site.

Since the start of Hanford Site operations in the mid-1940s, artificial recharge from wastewater disposal facilities has been several times greater than the estimated recharge from natural sources. This caused an increase in the water-table elevation over most of the Hanford Site and the formation of groundwater mounds beneath major wastewater disposal facilities. However, beginning in 1988, production activities on the Hanford Site closed. This resulted in a decrease of wastewater disposal and subsequent decreases in water-table elevation over much of the site. As the Hanford Site's mission changed to include environmental cleanup and restoration, the volume of wastewater discharged to the soil column has been greatly reduced through the efforts of the Waste Minimization and Pollution Prevention Program (DOE/RL-91-31, Rev. 1). For

Since the mid-1940s, wastewater disposal to the ground caused an increase in the water-table elevation over most of the Hanford Site. However, beginning in 1988, production activities on the Hanford Site closed. This resulted in a decrease of wastewater and a subsequent decrease in the water-table elevation over much of the site. 
example, $\sim 34$ billion liters of liquid effluents were discharged to the soil column in 1985, 14 billion liters were discharged to the soil column in 1990 , and $\sim 2.3$ billion liters were discharged to the soil column in 1997 (HNF-EP-0527-6). The reduction of wastewater discharge to the ground was accompanied by elimination of many discharge sites, including the 216-B-3 pond (B Pond) in the 200 East Area (decommissioned in 1997), the 216-U-10 pond (U Pond) in the 200 West Area (decommissioned in 1985), Gable Mountain Pond north of the 200 East Area (decommissioned in 1984 to 1988), and by diversion of waste streams to permitted facilities.

Sites actively releasing liquid effluent to the ground include the following:

- 200 Areas Treated Effluent Disposal Facility

- 616-A crib (also called the State-Approved Land Disposal Site)

- $4608 \mathrm{~B} / \mathrm{C}$ ponds (also called the 400 Area process ponds)

- 124-N-10 sanitary sewage lagoon

- $130-\mathrm{N}-1(183-\mathrm{N})$ filter backwash pond.

Groundwater in the unconfined aquifer flows toward and discharges to the Columbia River across most of the Hanford Site. Some variation to this generalization occurs where artificial recharge mounds are present or during times of high river stage.

\subsubsection{Historical Changes in Water Levels}

This section describes changes in the water table from 1944 to 1979 and 1979 to 1995 . The year 1944 was chosen to illustrate the water table before it was affected by Hanford Site effluent discharges and irrigation practices in the upper Cold Creek Valley. The year 1979 is representative of maximum, steady volumes of effluent discharge. The year 1995 marks the reduction and consolidation of many waste streams and their diversion to new treatment and disposal sites.

Between 1944 and 1979, water-table elevations at the Hanford Site increased in most areas. The greatest increases occurred near facilities where wastewater was discharged to the ground (Figure 3.6). Groundwater mounds associated with wastewater discharge to the ground formed in the 100,200, and 300 areas and in parts of the 600 Area. The two most prominent mounds formed near U Pond in the 200 West Area (22 meters) and near B Pond in the 200 East Area (10 meters). These mounds altered the natural flow patterns of the Hanford/Ringold aquifer system. Water levels changed continually during Hanford Site operations because of variations in the volume and location of wastewater discharged to the ground. Consequently, the movement of groundwater and its associated constituents also changed with time. Figure 3.7 shows the locations of the active discharge sites.

Reduced wastewater discharge to the soil column resulted in declining water levels for most of the Hanford Site. The greatest decline in water-level elevation from 1979 through 1995 was $~ 8$ meters in the 200 West Area near U Pond (Figure 3.8). Water levels in the 200 Areas have continued to decline since 1995.

\subsubsection{Hydraulic Properties}

Aquifer hydraulic properties, including hydraulic conductivity, specific yield, and effective porosity, are needed to calculate groundwater and contaminant travel times. These hydraulic properties are also necessary to conduct flow and transport modeling.

Hydraulic data for the unconfined aquifer are derived mainly from well pumping and slug tests and, in a few cases, laboratory tests of sediment samples. These results were documented in published and unpublished reports over the past 50 years. A summary of available data for the Hanford/Ringold aquifer system is provided in DOE/RW-0164, and an updated summary is provided in PNL-8337 together with an evaluation of selected pumping test analyses. Additional tests were conducted to support several specific Hanford Site projects. Examples are presented in BHI-00917, PNL-8332, PNL-8971, PNL-10195, PNL-10422, PNL-10633, WHC-SD-C018H-RPT-003, WHC-SDEN-DP-052, WHC-SD-EN-TI-052, and WHC-SDEN-TI-294. 
The distribution of unconfined aquifer transmissivity, which is the product of the vertically averaged horizontal hydraulic conductivity and the aquifer thickness, is shown in Figure 3.9. This distribution was determined from the results of well-pumping tests

Sediment with high hydraulic conductivity extends from the $100 \mathrm{~B} / \mathrm{C}$ Area, through the 200 East Area, and toward the southeast. Groundwater and contaminants flow through this zone more quickly than the surrounding sediment.

combined with a flow model calibration procedure (PNNL-11801). In Figure 3.9, the zone of high transmissivity that extends from northwest to southeast across the site generally corresponds with the main flow channel of the catastrophic floods that deposited the Hanford formation gravels. Thickness of the Hanford/Ringold aquifer system, which includes all the saturated sediment above basalt, is shown in Figure 3.10. Where they are found below the water table, the Hanford formation gravels make up the most permeable zones of the Hanford/Ringold aquifer system.
The hydraulic conductivity of these sediments is generally 10 to 100 times greater than the hydraulic conductivity of Ringold Formation gravels. In some areas of the Hanford Site, including the 200 West Area, the water table is below the bottom of the Hanford formation (see Figures 3.3 and 3.4). The aquifer transmissivity in these areas is generally much lower than the transmissivity in areas where Hanford formation sediments are saturated.

Specific yield values calculated from several multiple well tests range from 0.02 to 0.38 and have a mean of 0.15 (PNL-10886). For an unconfined aquifer, specific yield is approximately equal to effective porosity, which is important in calculating contaminant travel times. Aquifer specific yield, which is a measure of the volume of water released from aquifer storage in response to a change in the water-table elevation, is more difficult to measure than hydraulic conductivity and generally requires relatively longduration, aquifer pumping tests with observation wells (PNL-8539) or slug tests with observation wells (PNL-10835, Spane 1996). Even for these tests, the calculated specific yield is subject to errors that result from non-ideal test conditions, such as aquifer heterogeneity, anisotropy, and partially penetrating wells (PNL-8539). 


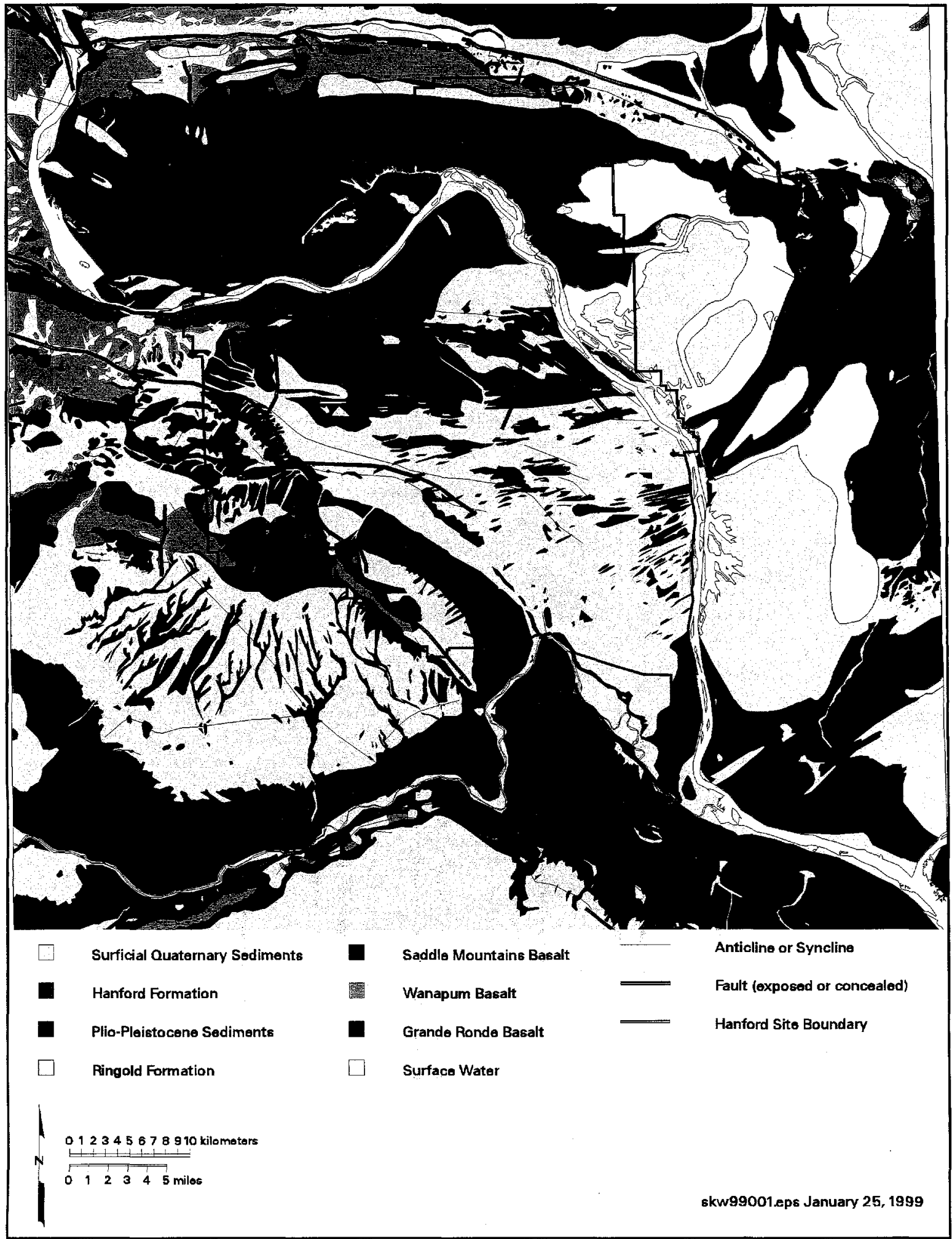

Figure 3.1. Pasco Basin Surface Geology and Structural Features (after Reidel and Fecht 1994a, 1994b) 


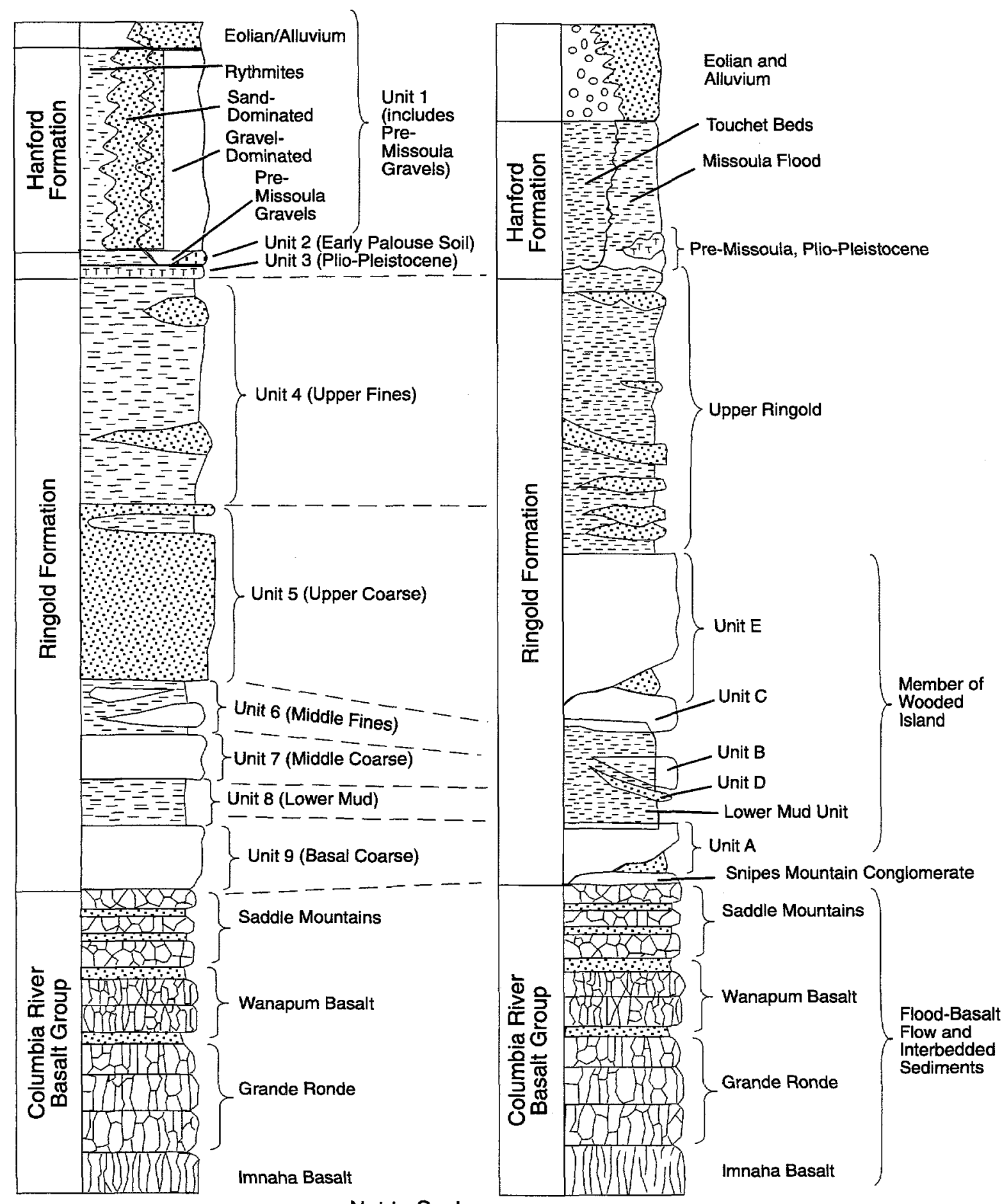

From PNL-8971

Not to Scale

After BHI-00184

RG98120214.14

Figure 3.2. Comparison of Generalized Hydrogeologic and Geologic Stratigraphy 


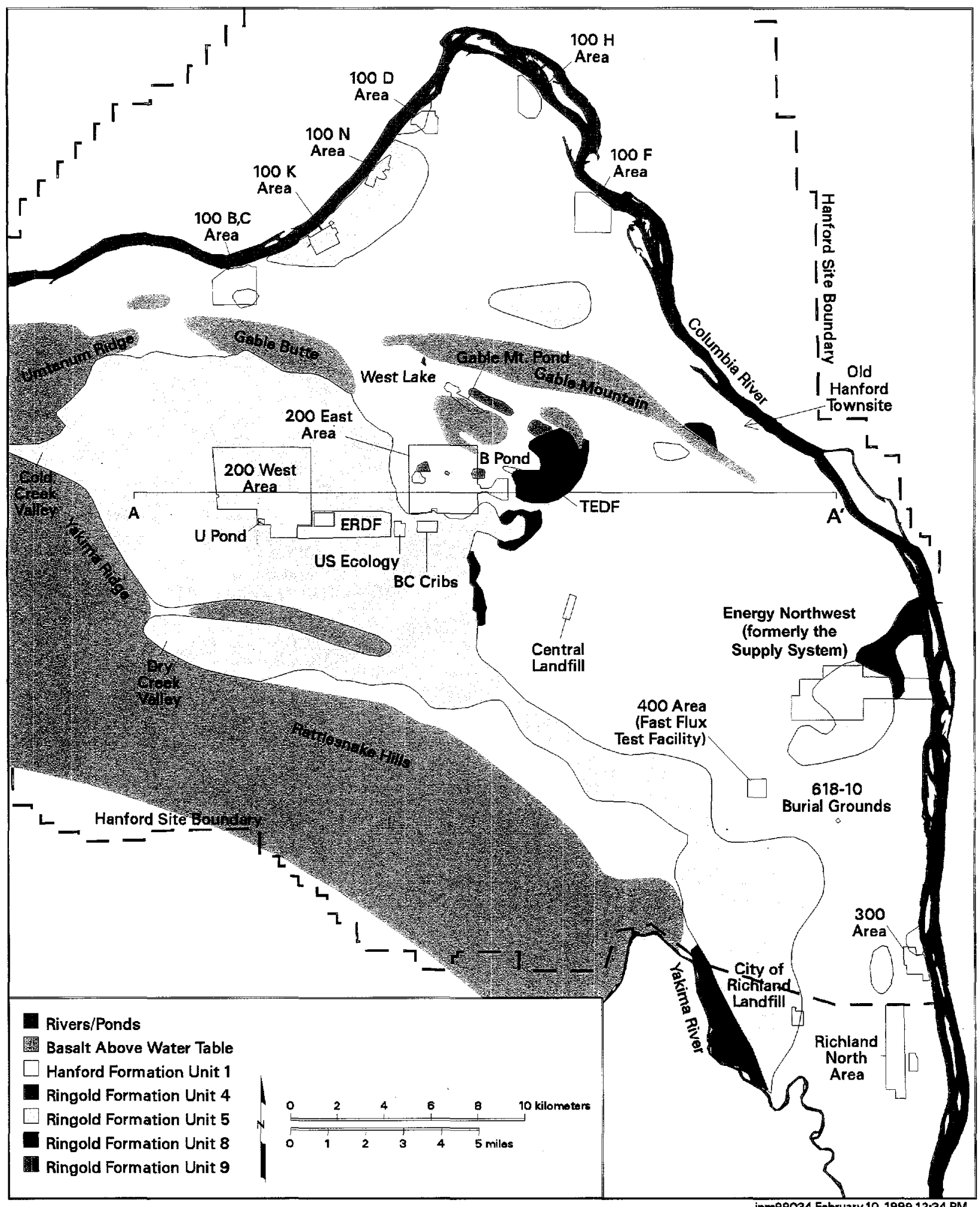

Figure 3.3. Hydrogeologic Units Present at Water Table, June 1998 


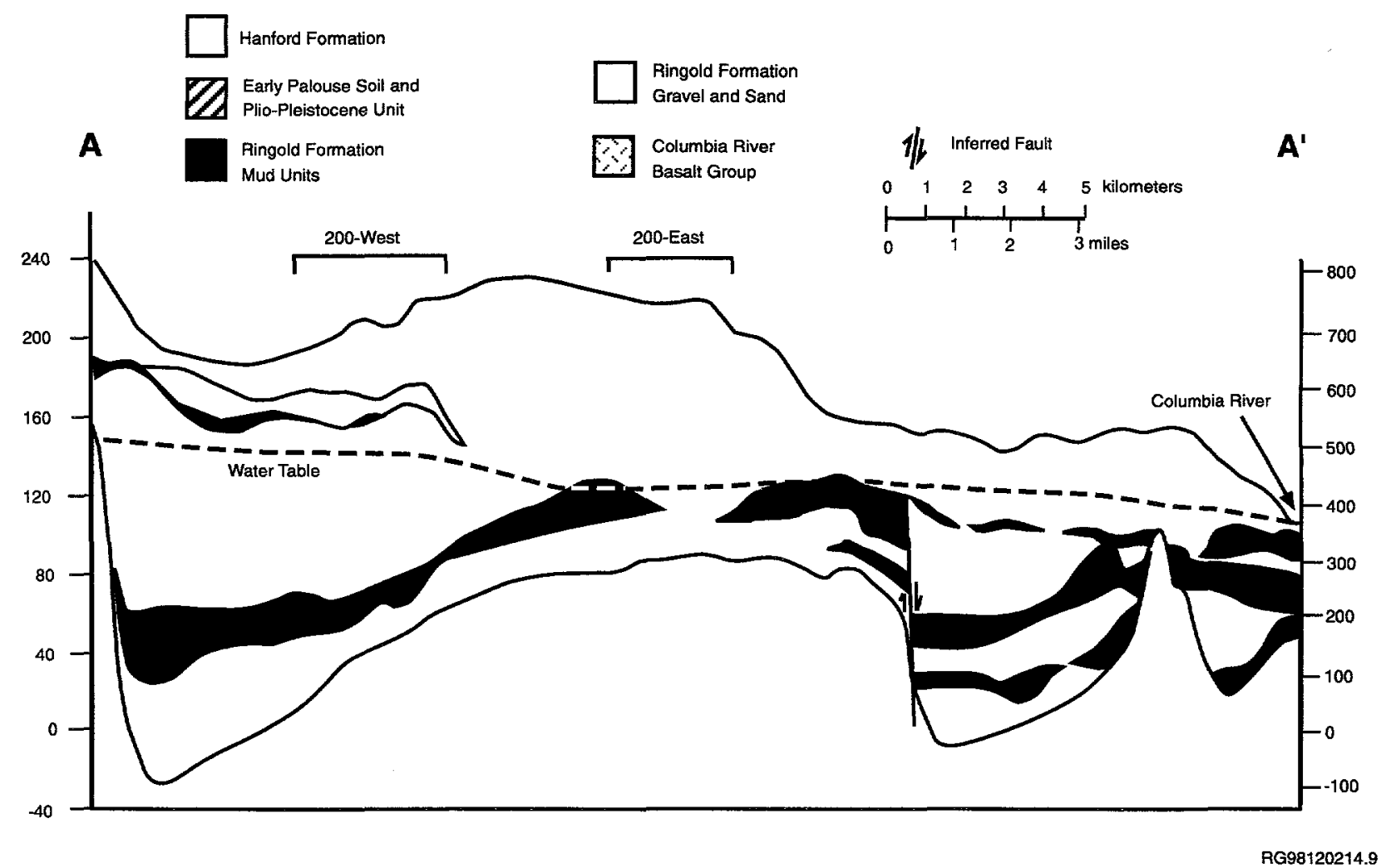

Figure 3.4. Hanford Site Geologic Cross-Section 


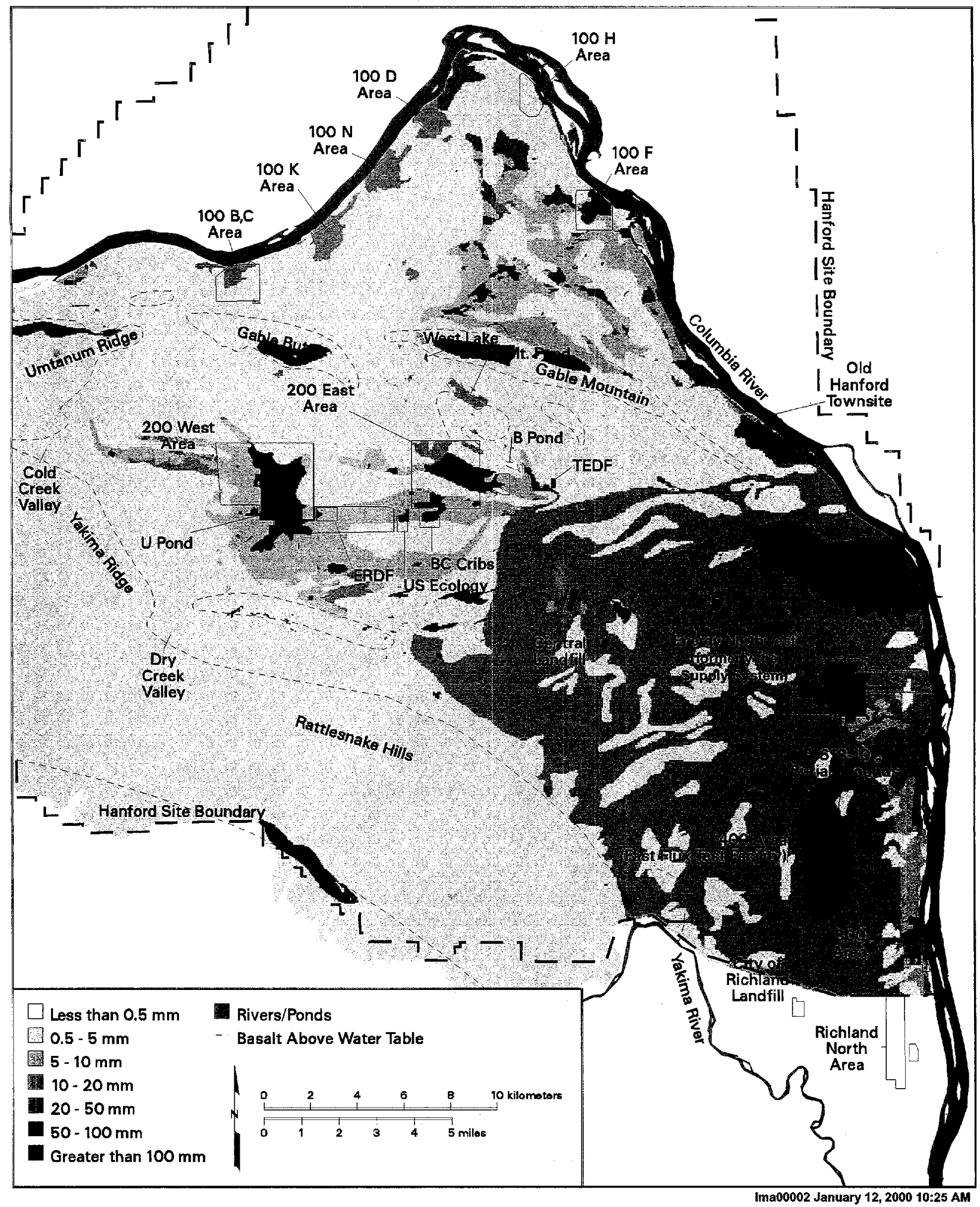

Figure 3.5. Estimated Annual Recharge from Infiltration of Precipitation and Irrigation (from PNL-10285) 


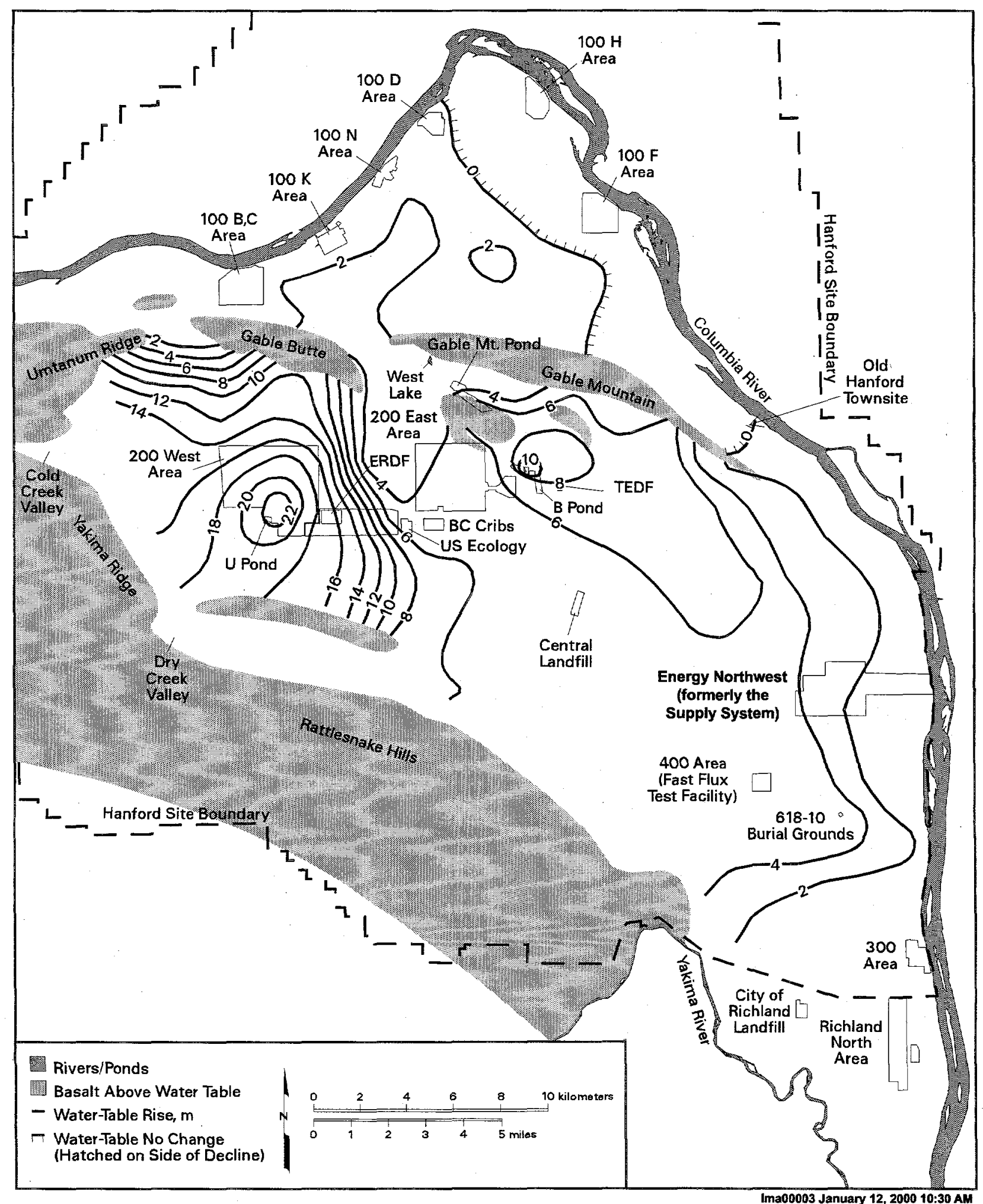

Figure 3.6. Changes in Water-Table Elevations, 1944 Through 1979 


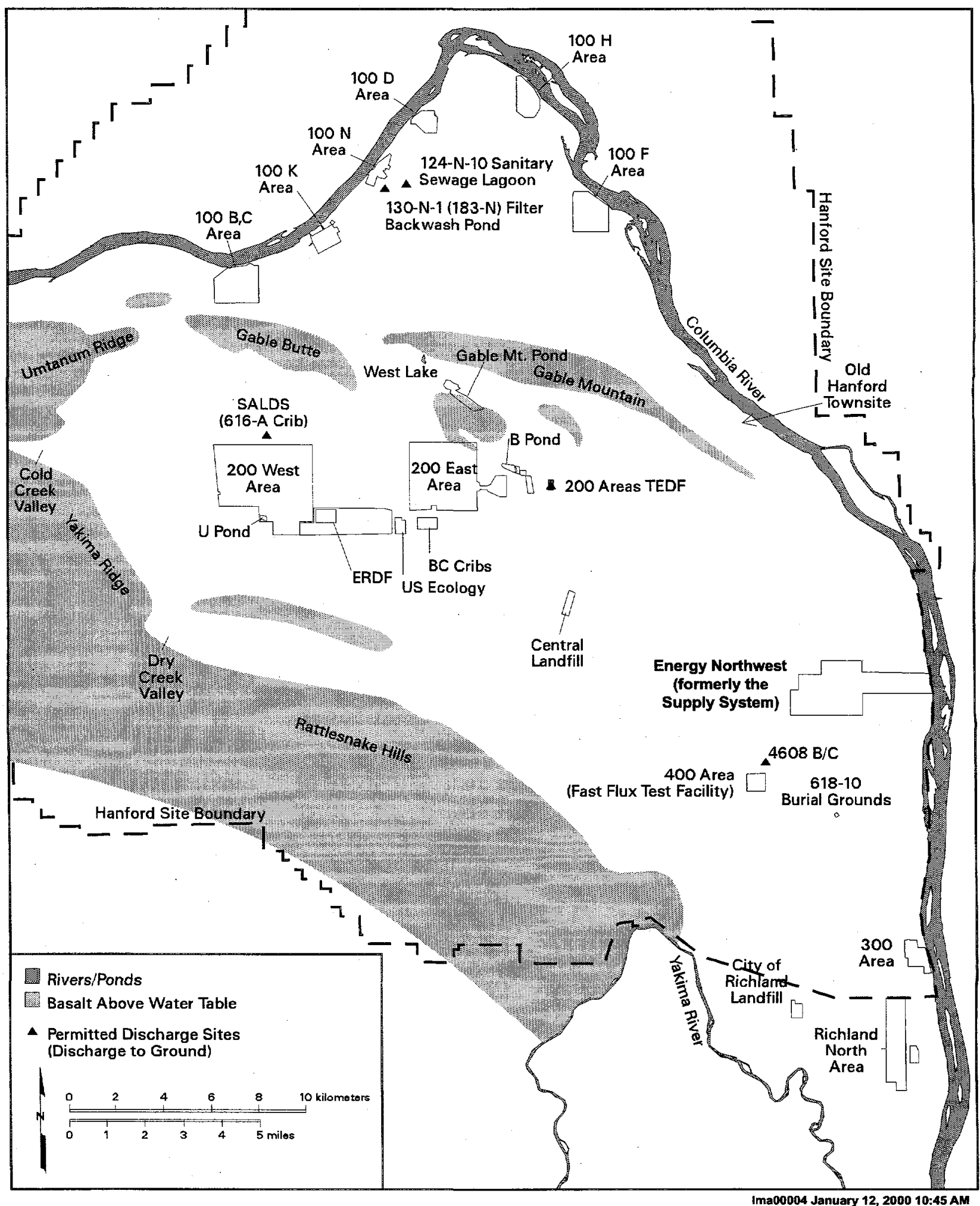

Figure 3.7. Active Discharge Sites 


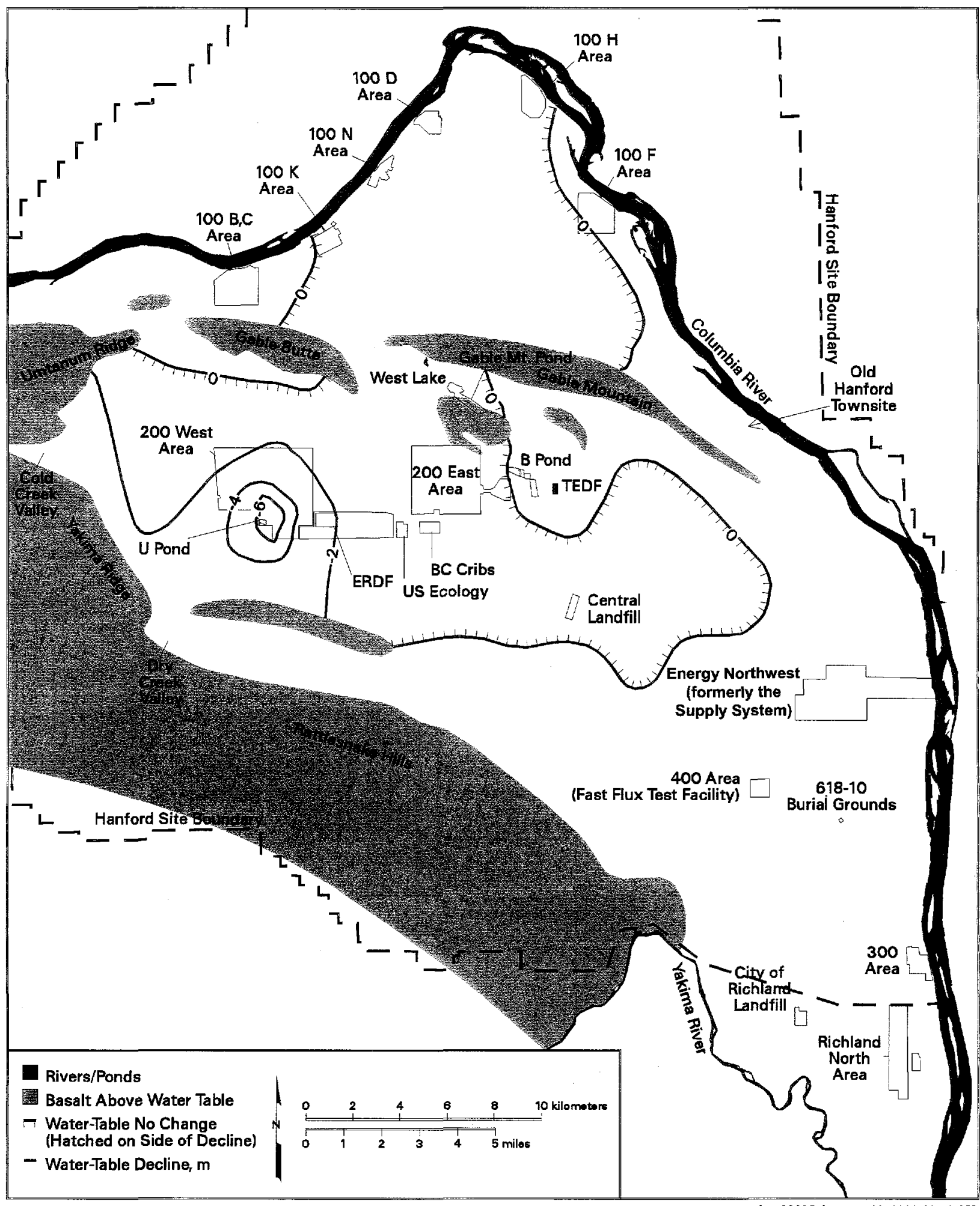

Ima00005 January 12, 2000 10:50 AM

Figure 3.8. Changes in Water-Table Elevations, 1979 Through 1995 


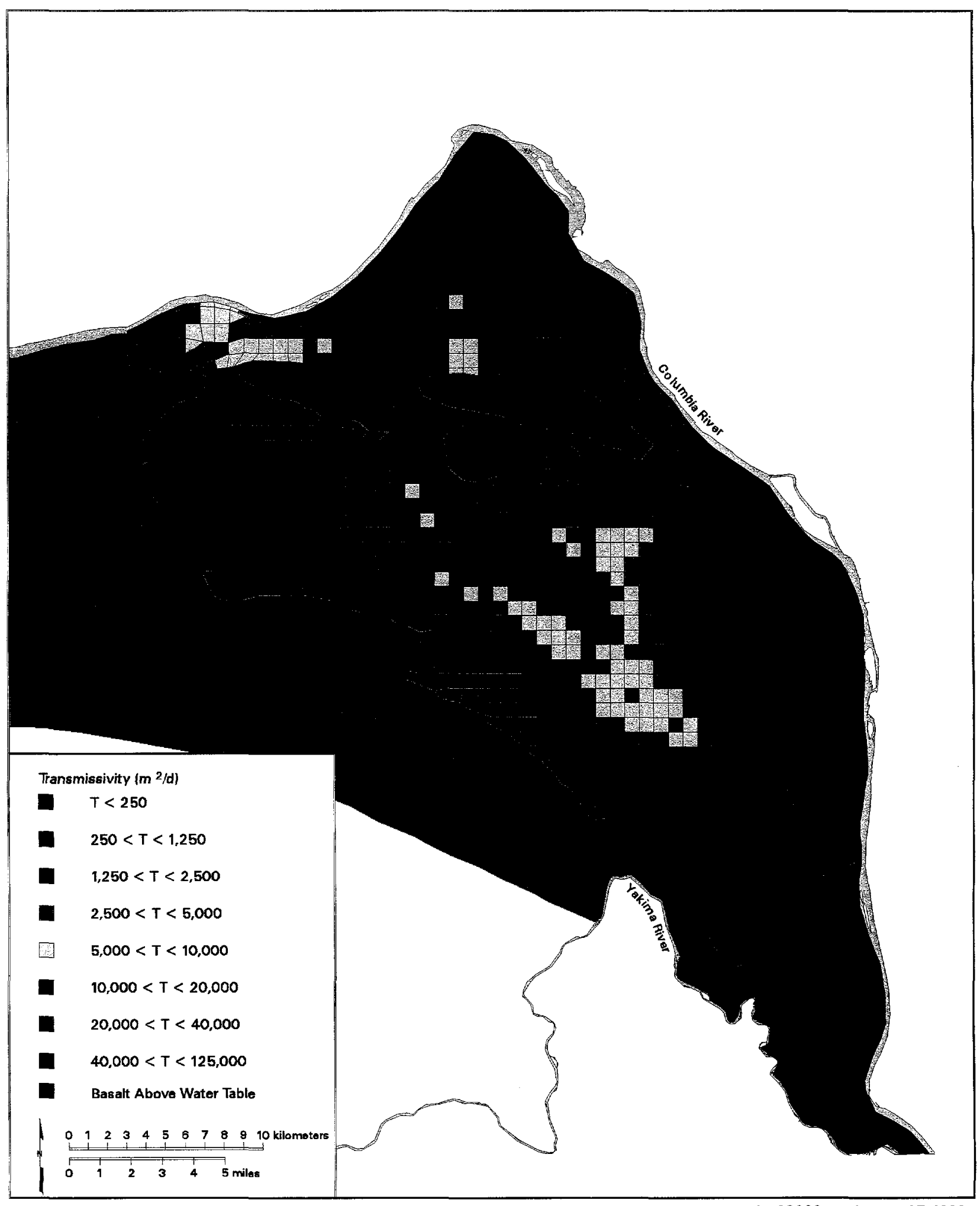

skw99002.eps January 25, 1999

Figure 3.9. Transmissivity Distribution from Model Calibration 


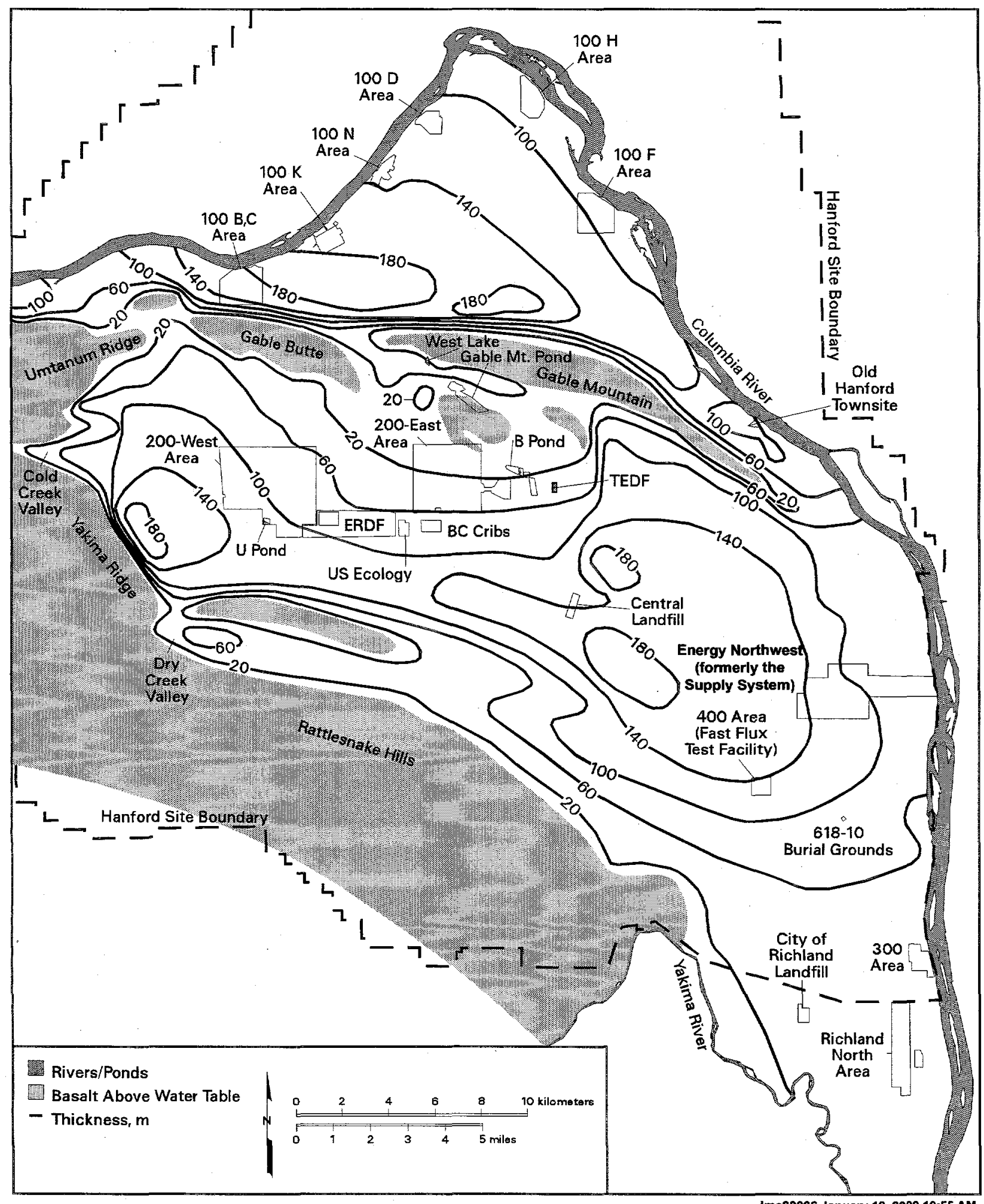

Figure 3.10. Saturated Thickness of Unconfined Aquifer System 
-

-

- 


\subsection{Facilities and Operable Units}

This section describes Hanford Site facilities and associated waste sites of significance to groundwater. It briefly describes the hydrogeology beneath each area or waste site. More detail is provided for sites with RCRA monitoring requirements. Geographic areas are described in a north-to-south, west-to-east order. Groundwater operable units have been defined for CERCLA investigations and are illustrated in Figure 4.1.

\subsection{Areas}

The 100 Areas include six separate areas where retired plutonium production reactors and support facilities are located. They are located along the Columbia River in the northern part of the Hanford Site. The unconfined aquifer in the $100 \mathrm{~B} / \mathrm{C}, 100 \mathrm{~K}$, $100 \mathrm{~N}$, and $100 \mathrm{D}$ areas is composed of either the Unit $\mathrm{E}$ Ringold gravels or Unit $E$ combined with the Hanford gravels, depending on the location of the water table (BHI-00917). In the $100 \mathrm{H}$ and $100 \mathrm{~F}$ areas, Ringold Unit $\mathrm{E}$ gravel is missing and the Hanford formation lies directly on the paleosol/overbank deposits of the Ringold Formation. In most of the 100 Areas, this unit forms a local aquitard, and the Ringold gravels below this mud are locally confined. Additional information on the hydrogeology of the 100 Areas is presented in BHI-00917, WHC-SD-EN-TI-023, and WHC-SD-EN-TI-294.

The water table in the 100 Areas is shallower than in the more elevated central regions of the Hanford Site. The depth to groundwater ranges from less than 1 meter adjacent to the river to more than 30 meters farther inland. Groundwater flow is generally toward the river in these areas, particularly during low river stage. However, in some areas along the river (e.g., west of $100 \mathrm{~B} / \mathrm{C}$ Area), groundwater appears to flow parallel to the river during most of the year. This may reflect the influence of buried river channel deposits.
The greatest change in groundwater level in the 100 Areas occurs in response to Columbia River stage, which can vary up to 4 meters during the year. Changes in river stage also cause periodic reversals in the direction of groundwater flow immediately adjacent to the river. When river stage is high (usually in the spring and early summer), water moves into the banks of the river, resulting in bank storage. When the river stage drops, water moves back toward the river, often appearing as riverbank seepage. The distance that water moves into the aquifer from the river depends on the magnitude and duration in river stage above groundwater elevation and the hydraulic properties of the intervening aquifer. The reversal of flow adjacent to the river also causes a pressure pulse in the aquifer that affects water levels in wells up to several hundred meters inland.

\section{Sources of Contamination in 100 Areas}

Facilities and sources of contamination in the 100 Areas include

B Reactor (1944-1968)
- C.Reactor (1952-1969)
D Reactor (1944-1967)
DR Reactor (1950-1964)
F Reactor (1945-1965)
- KW Reactor (1949-1965)
- KE Reactor (1955-1970)
N Reactor (1955-1971)
- Retention basins for reactor coolant
effluent
Liquid waste disposal cribs, trenches, and
drains
KW and KE fuel storage basins.

These sites include five RCRA units. 
Vertical hydraulic gradients are upward in the reactor areas, based on limited numbers of shallow/ deep well pairs or clusters. This upward gradient is evident within the Hanford/Ringold aquifer system and is characteristic of an area of groundwater discharge. There is also an upward gradient between the basaltconfined aquifer and the overlying sediments.

\subsubsection{B/C Area}

The $100 \mathrm{~B} / \mathrm{C}$ Area is the reactor area farthest upstream along the Columbia River (Figure 4.2). The stratigraphy consists of the Ringold and Hanford formations. The unconfined aquifer lies within silt, sand, and gravels belonging primarily to the Ringold Formation and is $\sim 34$ meters thick (BHI-00917, WHC-SD-EN-TI-133). The upper portion of the unconfined aquifer lies locally within the lowermost Hanford formation. The top of the paleosols and overbank deposits of the Ringold Formation form the bottom of the unconfined aquifer. The depth to the water table varies from less than 1 meter near the river to greater than 30 meters farther inland. Depending on the stage of the Columbia River, the groundwater flows in slightly different directions. The average of all those directions is toward the north or northeast. Local confined aquifers lie within the Ringold Formation between the paleosol/overbank deposits and the top of the basalt.

\section{Past disposal of liquid waste in the $100 \mathrm{~B} / \mathrm{C}$ Area contaminated groundwater with tritium and strontium-90.}

B Reactor began operating in 1944 and operated until 1968. C Reactor operated from 1952 to 1969. The $B$ and $C$ Reactors used a single-pass system for cooling water (i.e., cooling water passed through the reactor and was discharged to the Columbia River). No facilities or waste-disposal sites are currently operating in the $100 \mathrm{~B} / \mathrm{C}$ Area. The facilities noted in the following sections, which are associated with former reactor operations, are being decommissioned and remediated in accordance with CERCLA. A description of reactor operations and associated hazardous waste sites is presented in WHC-SD-EN-TI-220.

For CERCLA environmental restoration activities, the $100 \mathrm{~B} / \mathrm{C}$ Area is divided into two source operable units that contain hazardous waste sites at or near the surface (100-BC-1 and 100-BC-2). A single groundwater operable unit (100-BC-5) addresses contamination at and below the water table. It extends from beneath the source operable units laterally to adjacent areas where contamination may pose a risk to human and ecological receptors. For the 100 Areas, the lateral boundary is generally considered to be where Hanford Site groundwater meets Columbia River water. This interface occurs along the riverbanks and within the riverbed substrate.

High-priority waste sites include liquid waste disposal sites near the reactor buildings, solid waste burial grounds, retention basins used for reactor coolant water, liquid waste disposal trenches, and associated effluent pipelines. Descriptions of high-priority waste sites are presented in the proposed plans for remediation activities in each of the source operable units (DOE/RL-94-99; DOE/RL-95-66, Draft A), and are summarized below.

The 116-B-11 and 116-C-5 retention basins are located in the northern part of the $100 \mathrm{~B} / \mathrm{C}$ Area. These basins received enormous volumes of reactor coolant effluent that contained radionuclides and metals. They held the effluent for a short time to allow thermal cooling and radionuclide decay before the effluent was discharged to the Columbia River. The basins developed significant leaks, creating a mound on the underlying water table that facilitated the spread of contamination. Remedial action at these sites included excavation of contaminated sediment. The 116-C-5 retention basin was excavated to a depth of 5.6 meters in 1996 through 1998, and the 116-B-11 basin was excavated to 4.6 meters in 1998 .

When a reactor fuel element failed, the 116-B-1 and 116-C-1 liquid waste disposal trenches received coolant effluent that was highly radioactive. The 
effluent was held briefly in the retention basins and was then diverted to the nearby liquid waste disposal trenches instead of to the river. The trenches were unlined and intended as soil-column-disposal sites because the natural soils were known to retain several radionuclides of concern. Both trenches have been excavated to remove contaminated soil.

Relatively small soil-column-disposal facilities such as cribs, trenches, and French drains were located near the reactor buildings. Contaminated water and sludge from fuel storage basins at each reactor were disposed to trenches. Many of these smaller facilities also have been excavated.

Solid waste from reactors, including piping and equipment, were disposed in unlined trenches, buried metal culverts, or buried concrete pipes.

\subsubsection{K Area}

Geologic units beneath the $100 \mathrm{~K}$ Area from the surface downward include eolian silty sand, Hanford formation (sandy gravel, gravelly sands, sand), Ringold Formation Unit E (sandy gravel, gravelly sand), and Ringold Formation paleosols and overbank deposits (silt, sandy silt) (WHC-SD-EN-TI-155). The water table is $\sim 22$ meters below ground surface near the $\mathrm{KE}$ and $\mathrm{KW}$ reactor buildings, within Unit $\mathrm{E}$. Locally, the bottom of the unconfined aquifer is the top of the paleosols and overbank deposits $\sim 27$ meters below the water table (WHC-SD-EN-TI-294). Depending on the time of year, the groundwater flows in slightly different directions. The average of those directions is toward the north. Pumping and injection wells located east of the $100 \mathrm{~K}$ Area perturb this flow locally. High river stage also affects groundwater flow, inducing an eastward component.

The $100 \mathrm{~K}$ Area contains two former plutoniumproduction reactors (Figure 4.3). The KW Reactor operated between 1955 and 1970; the KE Reactor operated between 1955 and 1971. A description of operations and associated hazardous waste sites for the $100 \mathrm{~K}$ Area is presented in WHC-SD-EN-TI-239. A pump-and-treat system to remove chromium from groundwater between the 116-K-2 liquid waste disposal trench (i.e., 100-K mile-long trench) is currently in operation.

Past disposal of liquid waste in $100 \mathrm{~K}$ Area contaminated groundwater with carbon-14, chromium, strontium-90, trichloroethylene, and tritium. Leaks in fuel storage basins in the past 10 years have added high concentrations of tritium to ground. water locally.

For CERCLA environmental restoration purposes, the $100 \mathrm{~K}$ Area is divided into several operable units. The 100-KR-1 and 100-KR-2 operable units deal with waste sites, spill/leakage locations, and facilities that may act as sources of hazardous materials. The 100-KR-1 Operable Unit deals with source sites nearest the river and includes the former retention basins for reactor coolant water and liquid waste disposal trenches. The 100-KR-2 Operable Unit deals with source sites farther inland and includes the reactor complexes and water treatment plants.

The 100-KR-4 Operable Unit deals with groundwater that underlies the $100 \mathrm{~K}$ Area. This operable unit also focuses on adjacent groundwater and surface water (i.e., the river) that may be impacted by contaminated groundwater from $100 \mathrm{~K}$ Area operations. Riverbank seepage, riverbed sediment pore water, and sediment contacted by contaminated groundwater from the $100 \mathrm{~K}$ Area are included in the operable unit.

The KW and KE fuel storage basins in the reactor buildings are functioning facilities that hold irradiated fuel rods from $\mathrm{N}$ Reactor. They represent one of the most significant cleanup challenges on the Hanford Site. In the past, large amounts of radiologically contaminated water leaked from the KE basin, and the underlying soil column contains a significant amount of radionuclides. 
Each reactor had a liquid waste disposal facility that is a potential source for current groundwater contamination. The $116-\mathrm{KW}-2$ and $116-\mathrm{KE}-3$ injection wells/drain fields received storage basin effluent from the sub-basin drainage collection systems (WHC-SD. EN-TI-239). The facilities consist of drain fields containing perforated well casings that extend to below the water table. Radionuclides may have accumulated in the soil column beneath these drain fields, and contamination was probably introduced directly to groundwater via the well casings.

Two other important sources of contamination near the reactor buildings are the $116-\mathrm{KW}-1$ and $116-\mathrm{KE}-1$ cribs, which received condensate from processing inert gases in the reactors. Irradiation of reactor atmosphere gases resulted in carbon-14 and tritium in the condensate that was disposed to the cribs. Approximately 200 curies of carbon- 14 and 200 curies of tritium were discharged to these cribs during reactor operations.

The 116-K-2 liquid waste disposal trench is located northeast of the KE Reactor. It was designed as a soilcolumn liquid effluent disposal facility and operated between 1955 and 1971. 116-K-2 is the largest radioactive liquid waste trench in the 100 Areas and received significant quantities of chemical waste. Solutions containing chromium that were discharged to the trench were primarily decontamination solutions and routine coolant water that leaked from the retention basin and floor drains in the KW and KE reactor buildings. Solutions contributing the most radionuclides were decontamination solutions, shielding water from the fuel storage basins, and coolant water that contained debris from fuel element failures.

Coolant for these reactors was piped to the 116-KW-3 and 116-KE-4 water retention basins, which were steel tanks located $\sim 300$ meters from the Columbia River. Thermal cooling and decay of short-lived radionuclides occurred in these tanks. The coolant was then discharged into the river via large diameter pipes. Significant amounts of coolant water leaked from the retention basins to the ground, as well as to the
116-K-2 liquid waste disposal trench because of faulty valves and associated piping.

The area immediately south of the $183-\mathrm{KE}$ water treatment plant was the facility that received chemicals. Tank car loads of sodium dichromate and other chemicals were transferred to other locations from this point. During transfers, highly concentrated solutions spilled and drained into the soil. A similar receiving area for chemicals existed behind the $183-\mathrm{KW}$ water treatment plant.

\subsubsection{N Area}

The unsaturated zone in the $100 \mathrm{~N}$ Area lies in the Hanford formation and the upper part of the Ringold Formation. The unconfined aquifer is contained in the sands and gravels of Ringold Formation Unit $\mathrm{E}$. The depth to the water table in the $100 \mathrm{~N}$ Area varies from less than 1 meter near the Columbia River to $\sim 21$ meters farther inland. The base of the unconfined aquifer is a clay-rich unit $\sim 12$ meters beneath the water table. One well is completed in a thin sand unit within this clay. Although no wells are completed in sandy units deeper in the Ringold Formation, information from deep boreholes near the $100 \mathrm{~N}$ Area indicates that these units may also act as local confined aquifers. The hydrogeology of the $100 \mathrm{~N}$ Area is described in more detail in WHC-SD-EN-EV-027.

Groundwater flows in slightly different directions during different times of the year. The average of those directions in the $100 \mathrm{~N}$ Area is toward the northwest (toward the Columbia River). When the river stage is high, the gradient reverses and groundwater may flow to the east near the river. Pumping wells near the river and injection wells farther inland (see Figure 4.4 for locations) affect groundwater flow locally.

Cooling water discharged to cribs in the $100 \mathrm{~N}$ Area contaminated groundwater with strontium-90 and tritium. 
The N Reactor operated from 1963 through 1987. The Hanford Generating Plant, which used steam from $N$ Reactor to generate electrical power for Energy Northwest (formerly the Washington Public Power Supply System), also shut down in 1987. A detailed description of the operational history of the $100 \mathrm{~N}$ Area and its associated waste sites is presented in WHCSD-EN-TI-251. Activities to decontaminate and decommission the facilities are in progress, as well as environmental restoration activities. Groundwater remediation efforts have begun, with the construction and operation of a pump-and-treat system that reduces the movement of strontium-90 toward the river (Ecology and EPA 1994).

For CERCLA environmental restoration purposes, the $100 \mathrm{~N}$ Area is divided into two operable units. The 100-NR-1 Operable Unit is a source operable unit that includes liquid, sludge, and solid wastedisposal sites associated with operation of $\mathrm{N}$ Reactor. The 100-NR-2 Operable Unit deals with groundwater that lies beneath the waste sites and adjacent areas, its entry into the Columbia River, and river sediment that might be impacted by contaminated groundwater from $100 \mathrm{~N}$ Area operations.

Four RCRA units are located in the $100 \mathrm{~N}$ Area (see Figure 4.4): 1301-N liquid waste disposal facility, 1324-N surface impoundment, 1324-NA percolation pond, and $1325-\mathrm{N}$ liquid waste disposal facility. The $1301-\mathrm{N}, 1324-\mathrm{NA}$, and $1325-\mathrm{N}$ sites were the most significant waste sites in $100 \mathrm{~N}$ Area in terms of their impact on groundwater.

The $1301-\mathrm{N}$ facility was the primary disposal facility for liquid waste from $N$ Reactor from 1963 until 1985. Cooling water that contained radioactive fission and activation products was discharged to this facility. Minor amounts of dangerous waste also were discharged, including ammonium hydroxide, cadmium, diethylthiourea, hydrazine, lead, morpholine, phosphoric acid, and sodium dichromate The 1301-N facility consists of a concrete basin with an unlined, zigzagging extension trench, covered with concrete panels.
The 1324- $\mathrm{N}$ impoundment was a treatment facility in service from May 1986 to November 1988. This facility was a double-lined pond that was used to neutralize high- and low-pH waste from a demineralization plant. There is no indication that the facility leaked during its use. The 1324-NA percolation pond is an unlined pond used to treat waste from August 1977 to May 1986 and to dispose treated waste from May 1986 to August 1990. The effluent to both facilities contained sulfuric acid and sodium hydroxide, whose $\mathrm{pH}$ was occasionally high or low enough to be classified as a dangerous waste.

The $1325-\mathrm{N}$ facility was constructed in 1983 , and $\mathrm{N}$ Reactor effluent was discharged to it and to the 1301-N facility. In 1985, discharge to $1301-\mathrm{N}$ ceased, and all effluent was sent to $1325-\mathrm{N}$. All discharge to $1325-\mathrm{N}$ ceased in late 1991 . The facility consists of a concrete basin with an unlined extension trench, covered with concrete panels.

\subsubsection{D Area}

The unsaturated zone in the $100 \mathrm{D}$ Area lies in the Hanford formation and the upper portion of the Ringold Formation. The unconfined aquifer is a sand and gravel unit, $\sim 3$ to 9 meters thick, which corresponds to Ringold Unit E. Depth to the water table ranges from less than 1 meter near the river to $\sim 25$ meters farther inland. The base of the aquifer is a fine-grained overbank interval, which is $\sim 15$ meters thick. The deeper Ringold Formation is believed to comprise more layers of clay, silt, and sand based on interpolations between wells elsewhere in the 100 Areas.

Chromium is the major groundwater contaminant in the $100 \mathrm{D}$ Area, originating at numerous past-practice sources.

Groundwater flows toward the north and northwest beneath most of $100 \mathrm{D}$ Area. Two pumping wells in the northern part of the area affect groundwater flow locally. Periods of high river stage also influence 
flow near the river, temporarily creating gradients sloping toward the east.

A pump-and-treat system to remove chromium from groundwater is operating at the northern end of the $100 \mathrm{D}$ Area. A test of an in situ method to reduce hexavalent chromium (toxic to aquatic organisms) to the less-toxic trivalent chromium is in progress at the southwestern corner of the area.

For CERCLA environmental restoration purposes, the $100 \mathrm{D}$ Area is divided into two operable units (100-DR-1 and 100-DR-2), which address hazardous waste sites at or near the ground surface. Groundwater underlying the $100 \mathrm{D}$ Area is part of the 100-HR-3 Operable Unit, which includes groundwater beneath the $100 \mathrm{H}$ Area as well (see Figure 4.1). Groundwater operable units focus on groundwater beneath the reactor areas, groundwater in adjacent areas, Columbia River water, and river sediment that might be adversely impacted by contaminated groundwater from the reactor area.

The $100 \mathrm{D}$ Area contains two former plutonium production reactors (Figure 4.5). D Reactor operated between 1944 and 1967 and DR Reactor between 1950 and 1964. Descriptions of operations and associated hazardous waste sites for the $100 \mathrm{D}$ Area are presented in WHC-SD-EN-TI-181.

The following summaries describe the main pastpractice waste sites that may have contributed to groundwater contamination. The summaries are based primarily on information presented in WHC-SD-ENTI-181.

The 116-D-7 and 116-DR-9 retention basins are located in the northern part of the $100 \mathrm{D}$ Area. They received enormous volumes of reactor coolant effluent that contained radionuclides and chromium. They held the effluent for a short time to allow thermal cooling and radionuclide decay, then discharged the effluent to the Columbia River via pipes. The basins developed significant leaks, creating a mound in the underlying water table. Contaminated soil was excavated at both of these sites in 1997 through 1999.
When a reactor fuel element failed, the 116-D-1 and 116-DR-2 liquid waste disposal trenches received highly radioactive coolant effluent. The effluent was held briefly in the retention basins and then diverted to the nearby trenches instead of the normal discharge to the river. The trenches were unlined and intended as soil-column-disposal sites. These trenches were also excavated to remove contaminated soil.

Relatively small soil-column-disposal facilities, such as cribs and French drains, were located near the reactor buildings. At each reactor, contaminated water and sludge from fuel storage basins were disposed to trenches and percolation ponds. Decontamination solutions, consisting of various acid solutions that picked up radionuclides and metals, were also disposed to the ground near the reactors.

Sodium dichromate, which was added to coolant water to inhibit corrosion, was typically transferred from railcars to storage tanks. It was then piped to the facilities where it was added to coolant water. Stock solution occasionally leaked and spilled at storage tanks on the northern side of the D Reactor building and from piping that transferred the materials to the 190-D building immediately west of the reactor. During the later period of operations, a sodium dichromate transfer station was established $\sim 300$ meters west of $\mathrm{D}$ and DR Reactors. At this location, significant amounts of sodium dichromate solution and washdown waste is assumed to have spilled.

\subsection{5 $100 \mathrm{H}$ Area}

The unsaturated zone and the unconfined aquifer in the $100 \mathrm{H}$ Area lie entirely in unconsolidated sands and gravels of the Hanford formation. Depth to the water table ranges from less than 1 meter near the river to $\sim 12$ meters farther inland. The saturated portion of the Hanford formation ranges in thickness from 2 to 6 meters (Peterson and Connelly 1992). This hydrogeologic unit is underlain by the more consolidated fluvial sands and overbank deposits of the Ringold Formation. Ringold gravels below this unit 
are locally confined. A comprehensive description of $100 \mathrm{H}$ Area stratigraphy is presented in WHC-SD. EN-TI-132.

Depending on the time of year, the groundwater beneath $100 \mathrm{H}$ Area flows in slightly different directions. The average of those directions is toward the east and southeast. Flow is locally affected by pumping wells and injection wells. Periods of high river stage occasionally create a potential for groundwater to flow to the southwest.

Remediation activities already completed include demolition and removal of the $183-\mathrm{H}$ solar evaporation basins (a waste storage facility) and the underlying contaminated soil. A pump-and-treat program to remove chromium from groundwater is currently under way.

Past disposal of waste in the $100 \mathrm{H}$ Area introduced chromium, nitrate, strontium-90, technetium-99, and uranium to the groundwater.

For CERCLA environmental restoration purposes, the $100 \mathrm{H}$ Area is divided into two source operable units (100-HR-1 and 100-HR-2) that deal with hazardous waste sites at or near the ground surface. Groundwater underlying the $100 \mathrm{H}$ Area is part of the 100-HR-3 Operable Unit, which also includes groundwater beneath the $100 \mathrm{D}$ Area. Groundwater operable units deal with groundwater beneath the reactor areas, groundwater in adjacent areas, Columbia River water, and river sediment that might be adversely impacted by contaminated groundwater from the reactor area.

The $100 \mathrm{H}$ Area contains one plutonium production reactor, which operated between 1949 and 1965. Descriptions of reactor operations and associated hazardous waste sites are presented in BHI-00127, prepared to support environmental restoration activities.

The 183-H solar evaporation basins, a former treatment, storage, or disposal facility, is RCRA regulated. The waste discharged to the basins originated in the 300 Area fuel fabrication facility. The waste was predominantly acid-etch solution that had been neutralized with sodium hydroxide. The acid solutions included chromic, hydrofluoric, nitric, and sulfuric acids. The waste solutions, described as supersaturated, contained various metallic and radioactive constituents (e.g., chromium, technetium, uranium). All waste has been removed, the facility has been demolished, and the underlying contaminated soil has been removed and replaced with clean fill. Groundwater monitoring continues because residual amounts of nitrate and fluoride remain in the soil, and these constituents are attributable to waste from the $183-\mathrm{H}$ solar evaporation basins.

The principal past-practice waste sites that may have contributed to groundwater contamination are described below and shown in Figure 4.6. The primary information source for these descriptions is BHI-00127, the technical baseline report for the $100 \mathrm{H}$ Area.

The $107-\mathrm{H}$ retention basin is located in the eastern part of the $100 \mathrm{H}$ Area adjacent to the Columbia River. The basin received enormous volumes of reactor coolant effluent that contained radionuclides and chromium, held the effluent for a short time to allow thermal cooling and radionuclide decay, then discharged the effluent to the river via pipes. The basin leaked at rates sufficient to create a mound on the underlying water table. Mounding facilitated the spread of contamination over a broad area that potentially exceeded the reactor area boundaries. Contaminated soil has been excavated from beneath this site.

The 107-H liquid waste disposal trench received highly radioactive coolant effluent that resulted when a reactor fuel element failed. The effluent was held briefly in the retention basin and then diverted to the nearby liquid waste disposal trench instead of normal discharge to the river. The trench was unlined and intended as a soil-column-disposal site. This site also has been excavated to remove contaminated soil.

Relatively small soil-column-disposal facilities, such as cribs and French drains, were located near the $\mathrm{H}$ Reactor building. Contaminated water and sludge 
from the fuel storage basin were typically disposed to nearby trenches, though the fate of the fuel storage basin effluents is not well documented. Decontamination solutions, consisting of various acid solutions that picked up radionuclides and metals, also were disposed to the ground near the reactor. Decontamination solutions contained large amounts of chromate.

\subsubsection{F Area}

The $100 \mathrm{~F}$ Area is located the farthest east and downstream of the other reactor areas. The unsaturated zone and unconfined aquifer lie in the Hanford formation (BHI-00917). Unconsolidated sandy gravel and silty sandy gravel dominate the aquifer. Ringold paleosols and overbank deposits, which are dominated by silt and clay with sandy interbeds, form the base of the aquifer. The thickness of the unconfined aquifer ranges up to a maximum of 9 meters. Depth to the water table ranges from less than 1 meter near the river to $\sim 14$ meters farther inland.

F Reactor operated from 1945 to 1965 . Like all of the other Hanford Site reactors, except N Reactor, it was cooled by a single-pass system (i.e., cooling water passed through the reactor and was discharged directly to the Columbia River).

Nitrate is the most widespread groundwater contaminant from past sources in the 100 F Area. Strontium-90, trichloroethylene, and uranium also are detected locally.

For CERCLA environmental restoration purposes, the $100 \mathrm{~F}$ Area is divided into two source operable units (100-FR-1 and 100-FR-2), which contain hazardous waste sites at or near the surface. A single groundwater operable unit (100-FR-3) deals with contamination at and below the water table; this area extends from beneath the source operable units laterally to adjacent areas where contamination may pose a risk to human and ecological receptors. For the 100 Areas, the lateral boundary is generally considered to be where Hanford Site groundwater meets Columbia River water. This interface occurs along the riverbanks and within the riverbed substrate.

High-priority waste sites include retention basins for reactor coolant water, liquid waste disposal trenches, associated effluent pipelines, French drains near the F Reactor building, and burial grounds that received radioactive and mixed waste (Figure 4.7). Descriptions of high-priority waste sites are presented in the proposed plans for remediation activities in each of these source operable units (DOE/RL-95-54, Draft B; DOE/RL-95-92, Decisional Draft), and are summarized below.

The greatest volume of liquid waste in the $100 \mathrm{~F}$ Area was associated with the $116-\mathrm{F}-14$ retention basin and pipelines that lead to the basin from the F Reactor building. The retention basin is located near the Columbia River in the eastern part of the $100 \mathrm{~F}$ Area and received enormous volumes of reactor coolant water effluent that contained radionuclides and sodium dichromate. The basin held the effluent for a short time to allow thermal cooling and radionuclide decay and then discharged it to the Columbia River. The basin developed significant leaks, creating a mound on the underlying water table that facilitated the spread of contamination.

The 116-F- 2 overflow trench received highly radioactive effluent from the $116-\mathrm{F}-14$ retention basin and $F$ Reactor. A second trench (116-F-9) also is located near the retention basin and received liquid waste from cleaning the experimental animal laboratories. The trenches were unlined soil-column-disposal sites.

Other prominent liquid waste disposal sites include cribs and French drains near the $\mathrm{F}$ Reactor building. The 116-F-6 and 116-F-3 trenches received cooling water and sludge from $F$ Reactor. The 116-F-1 trench received liquid waste from $F$ Reactor and associated buildings. Effluent discharged to these facilities contained radionuclides and metals. 
Solid waste burial grounds are located in the southwestern part of the $100 \mathrm{~F}$ Area. They were used to dispose of contaminated equipment, animal waste from the experimental animal laboratories, or coal ash and soil.

\subsection{West Area}

The 200 West Area is located on the central plateau of the Hanford Site. The unconfined aquifer lies almost entirely in Ringold Unit $E$ gravels, the saturated thickness of which varies from $\sim 65$ meters to greater than 150 meters. The Ringold lower mud unit defines the base of the unconfined aquifer in much of the 200 West Area, but is absent in an area north of the 200 West Area (WHC-SD-EN-TI-014). Where the lower mud unit is absent, the top of the basalt defines the bottom of the unconfined aquifer. A semiconfined suprabasalt aquifer lies in Ringold Unit A gravels between the lower mud unit and the basalt. The depth to the water table in the 200 West Area varies from $\sim 50$ meters to greater than 100 meters.

In the 200 West Area, groundwater flows from the basalt ridges and Cold Creek Valley to the west of the Hanford Site and flows primarily to the north and east. Residual effects from the groundwater mound associated with the former U Pond and other 200 West Area discharge facilities continue to dominate the water table in the 200 West Area.

Only two CERCLA groundwater operable units (200-UP-1 and 200-ZP-1) relate to 200 West Area contamination (see Figure 4.1). The 200-UP-1 Operable Unit includes the groundwater contamination originating in the southern part of the 200 West Area. Currently, technetium-99 and uranium contamination in the vicinity of $U$ Plant are being addressed by the 200-UP-1 interim action. The 200-ZP-1 Operable Unit includes groundwater contamination originating in the northern part of the 200 West Area. Carbon tetrachloride is being removed from groundwater and soil vapor in this operable unit.
The 200 West Area (Figure 4.8) was used historically for chemical separation and purification of plutonium and associated waste management. For reasons of safety and security, the area was established with a significant spatial separation from the 200 East Area and with some duplication of function. The following sections discuss waste sites associated with T Plant, Reduction-Oxidation (REDOX) Plant, U Plant, and Plutonium Finishing Plant (formerly known as Z Plant). RCRA and other disposal sites are discussed separately, and in slightly more detail.

\section{Sources of Contamination in 200 West Area}

Potential sources of contamination in the 200 West Area are associated with T Plant, U Plant, the REDOX Plant, and the Plutonium Finishing Plant. The waste sites include

- six single-shell tank farms $(S, S X, T, T X$, TY, U)

- five double-shell tank farms (AN, AP, AW, $A Y, A Z)$

- liquid waste disposal cribs, ditches, and ponds

- low-level waste burial grounds

- eight of these sites are RCRA waste management areas.

\subsubsection{Plutonium Finishing Plant}

Z Plant, in the western 200 West Area, was constructed in 1949 to purify plutonium and reduce it to a metallic state. In the early 1980 s, the plant was modernized and renamed the Plutonium Finishing Plant. The mission of the plant remained essentially unchanged, but liquid discharges were significantly reduced. The spent process solutions from the Plutonium Finishing Plant contained carbon tetrachloride, nitric acid, and isotopes of plutonium and americium 
(transuranic waste). Transuranic contaminants typically remain bound in the soil column at relatively shallow depths, though there are exceptions, particularly where complexants for plutonium were present in the waste stream. Liquid waste discharge to cribs and trenches in this area resulted in the accumulation of an estimated 20,000 curies of americium-241 and plutonium-239 in the soil column (DOE/RL91-32, Draft B; WHC-EP-0674). Based on relative hazard (e.g., dividing curie quantities of americium-241 and plutonium-239 by the appropriate health/risk standard), the Plutonium Finishing Plant liquid waste disposal sites are some of the most significant sources of radioactive contamination in the vadose zone at the Hanford Site.

The Plutonium Finishing Plant, originally called Z Plant, recovered and "finished" plutonium starting in late 1949. Waste sites associated with this plant contaminated groundwater with carbon tetrachloride, nitrate, and other organic contaminants.

Immediately below the 216-Z-1A tile field distributor pipes, concentrations of transuranic waste up to $25,000,000 \mathrm{pCi} / \mathrm{g}$ are inferred from spectral gamma logging, and grab samples of shallow sediment (upper 6 meters) were found to contain up to $4,300,000 \mathrm{pCi} / \mathrm{g}$ plutonium-239/-240. See RHO-ST-17 for details. The distribution of sediment greater than $100,000 \mathrm{pCi} / \mathrm{g}$ was limited to the head end area and around the primary distribution line (center). The dissolved transuranic waste, in either an aqueous and/or an organic phase, was more widely distributed across the footprint of the disposal facility and with depth.

Similar conditions exist at the $216-Z-9$ and -18 facilities, which received the same waste stream as the 216-Z-1A tile field. A characterization study was done at the 216-Z-9 trench (ARH-2207, ARH-2915), where soil samples were obtained from shallow drill holes and analyzed for plutonium. Those samples, however, were all obtained from the upper 3 meters; therefore, little can be said about the distribution of transuranic waste beneath the trench. In 1977 and 1978 , an attempt was made to remove much of the soil contaminated with transuranic waste at shallow depths beneath the 216-Z-9 trench (RHO-ST-21).

Unlike the acidic waste streams sent to the 216-Z-1A, -9 and -18 facilities, the waste stream sent to the $216-Z-12$ crib was waste from neutral-basic process, analytical laboratories, and development laboratories that included 25,000 grams of plutonium (DOE/RL-91-58). Prior to disposal, the waste stream was adjusted to a $\mathrm{pH}$ of 8 to 10 . Not only did the $\mathrm{pH}$ of the waste stream differ, so did the organic content. The processes that generated waste sent to the 216-Z-12 crib did not use the large volumes of organic compounds that were part of the waste streams sent to the 216-Z-1A, -9 , and -18 facilities. However, sufficient carbon tetrachloride is present beneath the $216-Z-12$ crib to include it in the vapor extraction project.

Soil characterization at the $216-\mathrm{Z}-12 \mathrm{crib}$ (RHOST-44) took place in the early 1980 s. The results showed that plutonium concentration was highest $(1,000,000$ to $5,000,000 \mathrm{pCi} / \mathrm{g})$ immediately beneath the crib bottom. Plutonium concentration decreased rapidly with depth; concentration 3 meters below the crib was less than $1,000 \mathrm{pCi} / \mathrm{g}$ and at 10 meters below the crib was less than $1 \mathrm{pCi} / \mathrm{g}$. Plutonium concentration increased to a few tens of picocuries at 30 to 36 meters below the crib, where it is probably associated with a silt unit of greater sorption capacity (RHO-ST-44).

In addition to transuranic waste, the $216-\mathrm{Z}-1 \mathrm{~A}$, -9 , and -18 facilities received 570,000 to 920,000 kilograms of carbon tetrachloride (as both dissolved and separate liquid phases) between 1955 and 1973 (WHC-SD-EN-TI-248). The contaminated liquid waste was apparently intended to remain in the soil column; however, carbon tetrachloride was discovered in groundwater near the Plutonium Finishing Plant in the mid-1980s and was later found to be widespread in the 200 West Area. An expedited response action 
began in 1992 to reduce the carbon tetrachloride vadose zone source in the 200 West Area. This action was based on concerns that the carbon tetrachloride continued to spread to the groundwater. If left unchecked, the carbon tetrachloride would significantly increase the extent of groundwater contamination because of downward migration through the vadose zone as a dense, non-aqueous-phase liquid; as an aqueous phase dissolved in natural recharge water; and/or as a vapor phase. Once in groundwater, the dense, non-aqueous-phase liquid dissolves slowly, and its status in the vadose zone and groundwater is the subject of ongoing remediation and characterization efforts (BHI-00720, Rev. 2). Chloroform, nitrate, and trichloroethylene from the Plutonium Finishing Plant's cribs also produced plumes in the groundwater.

\subsubsection{T Plant}

T Plant, in the northern 200 West Area, used the bismuth phosphate process from December 1944 through August 1956 to separate plutonium from irradiated fuel (WHC-MR-0132). More recently, T Plant was used as an equipment decontamination facility. The waste facilities for $T$ Plant are located generally southwest of the plant and include cribs and singleshell tanks.

Waste management techniques changed during the period of operation, reducing the volume of waste produced for a given amount of fuel processed. Waste disposal practices were complex and changed, depending on available storage capacity and treatment technology. Between 1948 and 1956, the tanks used a cascading system to settle solids from second-decontamination-cycle

T Plant separated plutonium from irradiated fuel from December 1944 through August 1956. More recently, T Plant was used as an equipment decontamination facility. Waste sites near $T$ Plant have contaminated groundwater with iodine-129, nitrate, technetium-99, and tritium. waste. The supernatant from the last tank in the cascade was discharged to nearby cribs or specific retention trenches (WHC-MR-0227). From 1951 to 1956, cell drainage waste was discharged through the cascade with the second-cycle waste. From 1951, the 242-T evaporator was used to reduce the volume of firstdecontamination-cycle waste, though in 1953 to 1954 , some first-cycle waste was discharged to specific retention trenches. In 1954, operations to reduce the radioactivity of first-cycle waste began (WHC-MR-0132). The scavenged supernatant was disposed to the 216-T-26 crib (WHC-MR-0132, WHC-MR-0227). Waste from the original plutonium concentration facility in the 224-T building was settled in single-shell tanks before being discharged to cribs. In addition, WHC-MR-0227 indicated that in 1954 concentrated waste from the 242-T evaporator was discharged to the 216-T-25 trench. Thus, some of the most radioactive liquid waste was discharged to the ground rather than being stored in tanks. The waste discharged was closely related to tank waste; the tanks, however, apparently retained much of the solid waste.

There are a number of significant waste discharge sites in the T Plant area. The 216-T-28 crib received large amounts of water as well as some decontamination waste. The large volume of water discharged to the 216-T-28 crib, located just east of Waste Management Area TX-TY, may have facilitated migration of contaminants from nearby sources. The 216-T-19 crib and tile field are located south of Waste Management Area TX-TY and received a variety of waste, including condensate from the $242-\mathrm{T}$ evaporator and secondcycle supernatant waste. The 216-T-25 trench, located west of Waste Management Area TX-TY, received waste from the bottom of the evaporator.

\subsubsection{REDOX Plant}

Operation of the REDOX Plant began in 1951 and continued through 1967 . The primary mission of the REDOX Plant was to separate plutonium from uranium and fission products using countercurrent solvent extraction, eventually replacing the bismuth phosphate process used in $\mathrm{T}$ and $\mathrm{B}$ Plants. The process 
used an organic solvent (hexone) to separate plutonium from uranium fuel that had been dissolved in nitric acid.

The primary mission of the REDOX Plant (1951-1967) was to separate plutonium from uranium and fission products. Waste sites associated with this plant have contaminated groundwater with chromium, iodine-129, nitrate, technetium-99, and tritium.

Disposal facilities associated with the REDOX Plant are generally located to the west of the plant. A number of disposal facilities, including several ponds that received large amounts of water, are located south, outside the 200 West Area perimeter fence. Waste from the reduction/oxidation process is stored in Waste Management Area S-SX (single-shell tanks) and Waste Management Area SY (double-shell tanks). A number of disposal facilities located around Waste Management Area S-SX received waste from REDOX Plant operations, including condensate from the self-boiling waste tanks. Piping and transfer boxes that leaked during tank farm operations also may have released contaminants in this area. WHC-MR-0227 indicated that tank waste was not discharged directly to the ground via pumping or cascade overflow from Waste Management Area S-SX.

\subsubsection{U Plant}

U Plant was originally designed as a plutonium separation facility but was never used for that purpose. The plant was converted in 1952 to recover uranium from metal waste generated by the bismuth phosphate process, which had been stored in tanks up to that time. The uranium recovery process used tributyl phosphate solvent extraction; however, the process generated a large amount of waste to be stored in the single-shell tanks. In 1954, ferrocyanide and nickel scavenging of the waste from the uranium recovery began. Supernatant from the scavenged waste then was discharged to the ground after settling in 200 East Area single-shell tanks. Discharge was primarily to the BY cribs in the northern 200 East Area between 1954 and 1955; subsequent discharge in 1956 to 1958 was to the $\mathrm{BC}$ cribs and specific retention trenches located south of the 200 East Area (WHC-MR-0227). Other process waste was discharged to cribs generally south and west of $U$ Plant and radioactive waste was stored in Waste Management Area U (single-shell tank farm). Groundwater contaminants in the U Plant area include iodine- 129 , nitrate, technetium- 99 , trichloroethylene, and uranium.

From 1952 to 1958 , uranium was recovered at U Plant, located in the 200 West Area. Groundwater contaminants in the U Plant area include iodine-129, nitrate, technetium-99, and uranium.

\subsubsection{RCRA Facilities}

A number of facilities in the 200 West Area are monitored in accordance with RCRA. Additional detail on those facilities is warranted by the RCRA monitoring and reporting requirements.

\subsubsection{Single-Shell Tank Farms in 200 West Area}

The single-shell tanks that currently store hazardous, radioactive waste in the 200 West Area are located in waste management areas S-SX, T, TX-TY, and U. They are underlain by the Hanford and Ringold formations (Section 4.1.3 of DOE/RL-93-88 and WHC-SD-EN-AP-012, Rev. 0 and Rev. 1). The unconfined aquifer is contained entirely within the sands and gravels of Ringold Unit $E$ and is $\sim 60$ to $\sim 70$ meters thick. On a local scale, the top of the Ringold lower mud unit defines the base of the unconfined aquifer. The depth to the water table ranges from $\sim 64$ to $\sim 71$ meters below ground surface, and water levels are declining. 
The current direction of groundwater flow beneath Waste Management Area S-SX is toward the east to southeast. When the groundwater mound developed beneath U Pond, the direction of groundwater flow beneath waste management areas $\mathrm{T}$ and TX-TY was primarily to the north. As the mound began to decline following decommissioning of $U$ Pond in 1985, the direction of groundwater flow began shifting eastward. The direction of groundwater flow beneath the southern part of Waste Management Area TX-TY is most affected by withdrawal of groundwater for remediation of the 200-ZP-1 Operable Unit. In this part of Waste Management Area TX-TY, the groundwater flows to the south or southwest toward the groundwater withdrawal wells. Groundwater flow beneath Waste Management Area $\mathrm{U}$ is toward the east to northeast.

Waste management areas S-SX, T, TX-TY, and U have been designated as RCRA facilities since 1989. These tanks were constructed between 1943 and 1964 and, depending on dimensions, each held between $1,892,500$ and $3,785,000$ liters. Waste management areas $T$ and $U$ contain four, smaller, 200 -series tanks that hold 208,175 liters each. The waste in the tanks was generated by chemical processing of spent fuel rods using the tributyl phosphate, bismuth phosphate, reduction/oxidation, or plutonium-uranium-extraction processes.

The single-shell tanks received mixtures of organic and inorganic liquids that contained radionuclides, solvents, and metals originally discharged to the tanks as alkaline slurries. Waste management operations mixed various waste streams from numerous activities generated in the processing of spent fuel rods. Thus, the original content within each tank is difficult to determine. The situation is further complicated by subsequent chemical reactions, degradation, and decay of radionuclides. However, much recent work has been done to characterize the tank waste (e.g., LA-UR-96-3860). The radionuclide and chemical inventories of the single-shell tanks are summarized in WHC-SD-WM-TI-565, Rev. 1; waste types and historical operations at the tank farms are summarized in WHC-MR-0132.
Over 450,000,000 liters of liquid waste that cascaded through underground storage tanks were discharged to the vadose zone via cribs, trenches, and french drains (WHC-MR-0227). The estimated total quantity of radioactivity in the cascaded waste was 65,000 curies (decayed through December 1989).

Because of the large volume discharged, the entire soil column beneath many disposal sites in the 200 Areas became saturated. Breakthrough of mobile contaminants (e.g., chromium, fluoride, iodine-129, nitrate, technetium-99, tritium) occurred from the soil column to groundwater. Although the disposal of cascaded tank waste was terminated over 30 years ago, a long-term source of groundwater contamination continues to be the residual liquid held in soil pore spaces following drainage of free liquid at these sites. This is especially true if a source of moisture is present to transport the mobile waste constituents (e.g., enhanced natural infiltration resulting from unfavorable topography and/or coarse gravel covers present at some inactive disposal facilities, removal of vegetation, leaking water lines).

Leakage from single-shell tanks can also be a source of groundwater contamination under certain conditions. Eleven of the tanks at Waste Management Area S-SX are known or assumed to have leaked. At Waste Management Area T, 6 of 12 tanks are known or suspected to have leaked; at Waste Management Area TX-TY, 13 of 24 tanks are known or suspected to have leaked. The estimated total volume of such sources is, however, small (less than 4,000,000 liters) compared to the intentional soil-column-disposal volume $(450,000,000$ liters $)$ of very similar waste. However, there is growing evidence that downward movement of moisture and associated mobile contaminants from small volume leaks ( 100,000 liters) may be greater than previously thought. Small leak sources can also be mobilized if a driving force and/or a preferential vertical pathway is present to transport the contaminants through the vadose zone to groundwater. The role of various types of ground cover, or enhanced natural infiltration, and preferential pathways is, thus, a crucial issue in the tank farm areas. A treatability 
demonstration, consisting of a surface covering to limit infiltration, was initiated at the 216-B-57 crib a few years ago. Similar engineered covers are being considered for some single-shell tank farms to reduce infiltration.

Tank waste exists in the form of saltcake and sludge, which was left after the liquid was removed. However, there are small quantities of supernatant and interstitial liquids that could not be removed by pumping. The waste consists predominantly of sodium hydroxide and sodium salts of aluminate, carbonate, chromate, nitrate, nitrite, and phosphate. Some hydrous oxides of iron and manganese also are present. The principal radioactive components are radionuclides, such as cesium-137, strontium-90, and technetium-99, and actinide elements, such as neptunium, plutonium, thorium, and uranium. Some of the tanks also contain ferrocyanide, fluoride, or organic complexants.

\subsubsection{216-U-12 Crib}

This crib is located $\sim 610$ meters south of U Plant. The unsaturated sediment is composed of unconsolidated sandy gravel and sand of the Hanford formation, sandy silt and silt of the Plio-Pleistocene unit, and silty sandy gravel to gravelly sand of Ringold Unit $E$. The unconfined aquifer is within the silty sandy gravels of lower Ringold Unit $\mathrm{E}$ and is $\sim 53$ meters thick. The depth to the water table is $\sim 75$ meters below ground surface. The top of the Ringold lower mud unit locally defines the base of the unconfined aquifer beneath the crib. Details of the stratigraphy beneath the crib may be found in WHC-SD-EN-AP-108.

Groundwater flows toward the east-southeast near the crib. The average flow rate has been slowly decreasing as a result of a slight flattening of the water table in the vicinity of the crib.

The $216-\mathrm{U}-12 \mathrm{crib}$ is an unlined, gravel-bottomed, percolation crib that has bottom dimensions of 3 meters wide, 31 meters long, and 4.3 meters deep. The crib has a plastic barrier cover and is backfilled with the original excavated soil. A vitrified clay distributor pipe buried in gravel dispersed the effluent across the bottom of the crib. The crib received U Plant wastewater from April 1960 until February 1988, when it was permanently retired and replaced by the 216-U - 17 crib. The $216-U-12$ crib will not receive additional dangerous substances and will be closed in final status pursuant to WAC 173-303-610.

The wastewater disposed to the $216-\mathrm{U}-12 \mathrm{crib}$ contained dangerous waste and radioactive materials. Specifically, the waste was composed of effluent from U Plant and included 291-U-1 stack drainage and highly acidic process condensate from the $224-\mathrm{U}$ building. The 216-U-12 crib received this waste stream from April 1960 until 1972, when it was deactivated. The crib was reactivated in November 1981 and received U Plant waste until it was permanently closed in February 1988. An average of more than $150,000,000$ liters per year of effluent were disposed to this crib during its active life. Also, the crib received small amounts of radioactive waste that is known to have included nitric acid in addition to plutonium, ruthenium-106, strontium-89/-90, and uranium. In 1985 , physical controls and operating procedures were modified to avoid inadvertent discharge of hazardous chemicals to the wastewater stream.

\subsubsection{216-S-10 Pond and Ditch}

This facility is located south-southwest of the 200 West Area outside the perimeter fence. The stratigraphic section is similar to that at the 216-U-12 crib and includes the Hanford formation, the PlioPleistocene unit, and the Ringold Formation (WHCSD-EN-DP-052).

The water table is in the lower part of the upper Ringold unit at a depth of $\sim 70$ meters and is declining. During the operation of $U$ Pond, the groundwater flow direction at this facility was toward the southeast to east-southeast because of the influence of the large groundwater mound emanating from $U$ Pond. Now that the wastewater discharges have ceased to U Pond, water levels are declining, and the flow in the vicinity of this facility is returning to its prior direction (i.e., from west to east). 
Initially, the 216-S-10 facility consisted of an open, unlined ditch $\sim 1.8$ meters deep, $\sim 4$ meters wide, and 686 meters long. An open, unlined percolation pond, constructed at the southwestern end of the 216-S-10 ditch and 2.0 hectares in size, was also active during part of the time that the ditch received waste.

In August 1951, the ditch began receiving waste from the REDOX Plant. The pond was excavated and placed in service in February 1954. In October 1985, the pond and portions of the ditch were decommissioned and backfilled. The remaining portion of the ditch received non-dangerous, non-regulated waste from the 202-S building chemical sewer. The waste stream included cooling water, steam condensate, water tower overflow, and drain effluent. From 1985 to October 1991, physical controls and operating procedures were modified to avoid inadvertent discharge of hazardous chemicals to the wastewater stream. The effluent stream to the 216-S-10 facility was deactivated permanently in October 1991. The facility will not receive additional dangerous substances and will be closed in final status pursuant to WAC 173-303-610.

Releases of dangerous constituents to the 216-S-10 facility are poorly documented. DOE reported that radioactive waste was disposed to the facility as a result of contaminated floor and sewer drains at the REDOX Plant. In 1954 and 1983, DOE documented hazardous chemical releases that included aluminum nitrate, potassium dichromate, sodium chloride, sodium fluoride, sodium hydroxide, sodium nitrate, and sodium phosphate.

\subsubsection{Low-Level Waste Management Areas in 200 West Area}

Burial grounds 218-W-3A, 218-W-3AE, and 218-W-5 make up Low-Level Waste Management Area 3 in the north-central portion of the 200 West Area. Low-Level Waste Management Area 4 is in the south-central portion of the 200 West Area and comprises burial grounds 218-W-4B and 218-W-4C. LowLevel Waste Management Area 5 in the north-central portion of the 200 West Area has not been monitored for groundwater since fiscal year 1996 because the burial ground never received waste.

Low-Level Waste Management Areas 3 and 4 are underlain by the Ringold and Hanford formations. The unconfined aquifer is entirely within Ringold Unit $\mathrm{E}$. There are indications that the aquifer is locally semiconfined beneath fine-grained sediment in the northern portions of Low-Level Waste Management Area 3 (WHC-SD-EN-DP-049). The depths to the water table are $\sim 64$ to 74 meters below ground surface. The saturated thickness is $\sim 62$ to $\sim 75$ meters. The base of the aquifer is the lower mud unit of the Ringold Formation, except where the lower mud is not present (e.g., northern portion of Low-Level Waste Management Area 3). Where there is no lower mud, the top of the basalt defines the base of the unconfined aquifer.

Groundwater flows to the northeast beneath Low-Level Waste Management Area 3. With time, it is turning more eastward because of decreased liquid disposal in the 200 West Area. Water-level data from the wells that monitor the base of the unconfined aquifer indicate that the vertical gradient in this area is downward.

The flow of groundwater beneath Low-Level Waste Management Area 4 is primarily from west to east. However, as recently as 1995 , groundwater flow was from east to west. The 200-ZP-1 Operable Unit pump-and-treat project affects the pattern of groundwater flow beneath Low-Level Waste Management Area 4 because groundwater is withdrawn and treated to the east and injected back into the ground to the west of the facility. The vertical groundwater gradient in the unconfined aquifer appears to be downward.

Low-Level Waste Management Area 3 covers 74.3 hectares. Burial ground 218-W-3A began accepting waste in 1970 and received primarily ion-exchange resins and failed equipment such as tanks, pumps, ovens, agitators, heaters, hoods, vehicles, and accessories. Burial ground 218-W-3AE began operation in 1981 and contains low-level and mixed waste, including rags, paper, rubber gloves, broken tools, and industrial waste. Burial ground $218-\mathrm{W}-5$ first received 
waste in 1986 and contains low-level waste and lowlevel mixed waste, including lead bricks and shielding.

Low-Level Waste Management Area 4 covers 24.4 hectares in the south-central portion of the 200 West Area. Burial ground 218-W-4B first received waste in 1968 and contains mixed and retrievable transuranic waste in trenches and 12 caissons. One caisson is believed to contain mixed waste. Waste was first deposited in burial ground 218-W-4C in 1978. The transuranic, mixed, and low-level waste placed in burial ground $218-\mathrm{W}-4 \mathrm{C}$ included contaminated soil, decommissioned equipment, and transuranic waste.

\subsubsection{Other Facilities}

The State-Approved Land Disposal Site (also known as the $616-\mathrm{A}$ crib and project $\mathrm{C}-018 \mathrm{H})$ is located $\sim 500$ meters north of the 200 West Area northern boundary. This drain field receives treated effluent from the 200 Areas Effluent Treatment Facility near the northeastern boundary of the 200 East Area. The 200 Areas Effluent Treatment Facility receives liquid waste from various Hanford Site cleanup activities. This waste is stored temporarily in the Liquid Effluent Retention Facility (Section 4.3.3.7). A pipeline transports the treated effluent, occasionally containing high levels of tritium (up to 4,000,000 $\mathrm{pCi} / \mathrm{L}$ ), across the 200 Areas plateau to the StateApproved Land Disposal Site for disposal. This site is regulated by a state waste discharge permit and began receiving effluent in December 1995.

The Environmental Restoration Disposal Facility receives waste material generated by the environmental restoration program during remediation of the Hanford Site. It is located southeast of the 200 West Area. The facility contains two cells and will expand as needed to accommodate excavated soil and debris from remediation activities. This waste material may have elevated levels of radionuclides and/or hazardous materials. The site covers 4.1 square kilometers, but $\sim 67$ hectares were used for the initial waste cells and an additional 23 hectares for the first expansion. The facility is constructed as a single, 21 -meters-deep trench, consisting of a series of two side-by-side cells each measuring $152 \times 152$ meters at the base, with a finished wall slope of three horizontal to one vertical. Current dimensions are 433 meters long (north-south) by 220 meters wide (east-west) at the top of the trench. The trench design includes a double liner and leachatecollection system compliant with RCRA minimum technology requirements.

\subsection{East Area}

A recent investigation (PNNL-12261) concluded that the suprabasalt aquifer system in the 200 East Area is composed of at least two distinct aquifers: (1) an unconfined aquifer within gravels of the Hanford formation and Ringold Unit E; and (2) a confined aquifer in Ringold unit A, below the lower mud. Near $B$ Pond, the lower mud unit is above the water table and there is no unconfined aquifer. The depth to the water table in the 200 East Area varies from $\sim 65$ to 100 meters. The thickness of the saturated zone above the top of the basalt varies from 0 meters in the north to $\sim 80$ meters in the south.

In the 200 East Area, groundwater flows primarily in two general directions: to the northwest through Gable Gap (located between Gable Mountain and Gable Butte) and to the southeast toward the Columbia River. These flow directions are based on contaminant plume maps and water-level elevation data. However, the location of the divide between flow to the northwest and flow to the southeast is not discernible because the water table in the 200 East Area is nearly flat. The gently sloping water table corresponds to a high transmissivity zone that extends through the 200 East Area (see Figure 3.9).

Groundwater in the unconfined aquifer beneath B Pond previously flowed in a radial pattern. This radial pattern was attributed to a groundwater mound that developed when wastewater discharge was released to $B$ Pond in the past. Recently, however, it appears that the water-table mound in the unconfined aquifer has virtually disappeared, while a potentiometric high remains in the confined Ringold aquifer 
(PNNL-12261). Groundwater in the unconfined aquifer is presumed to flow around this area where the lower mud unit is present above the water table.

A downward hydraulic gradient between the unconfined aquifer and the upper basalt-confined aquifer occurs at $B$ Pond as a result of the groundwater mound. However, recent geochemical and hydrologic evidence suggests that an upward-directed gradient is possibly becoming re-established between the upper basalt-confined aquifer and the overlying unconfined aquifer near the former B Pond (PNNL-11986). An area of increased interaction between the unconfined aquifer and the upper basalt-confined aquifer was identified in the area north of the 200 East Area based on chemical and hydraulic head evidence (PNL-6313, RHO-RE-ST-12 P). The increased communication is likely caused by local erosion of the upper basaltconfining layer in this area (RHO-RE-ST-12 P).

Two groundwater operable units relate to 200 East Area contamination (200-BP-5 and 200-PO-1). The

\section{Sources of Contamination in 200 East Area}

Potential sources of contamination in the 200 East Area are associated with B Plant and the PUREX Plant. The waste sites include

- six single-shell tank farms $(A, A X, B, B X$, BY, C)

- five double-shell tank farms (AN, AP, AW, AY, AZ)

- one injection well

- liquid waste disposal cribs, ditches, and ponds

- low-level waste burial grounds

- ten of these sites are RCRA waste management areas. boundaries for these two operable units were defined (WHC-SD-EN-TI-019) by an east-west groundwater divide across the 200 East Area (see Figure 4.1).

The 200-BP-5 Operable Unit contains all plumes located north of the groundwater divide. Important plumes within the unit originated from B Plant's bismuth phosphate liquid disposal and include a plume of strontium-90, cesium-137, and plutonium-239/-240 centered around the 216-B-5 injection well. Another plume, derived from liquid waste disposal to the BY cribs, consists of cobalt -60 , cyanide, nitrate, and technetium-99. In fiscal year 1995, a pump-and-treat program successfully removed quantities of radionuclides and cyanide from plumes at the BY crib and 216-B-5 injection well.

The 200-PO-1 Operable Unit is being dealt with as a RCRA past-practice unit and encompasses the area south of the 200 East Area groundwater divide. The unit consists of plumes from PUREX Plant operations. Plumes of concern extend mostly to the south and east from the PUREX Plant. These plumes of iodine-129, nitrate, and tritium cover broad areas within and southeast of the 200 East Area. A number of small plumes or sporadic detections were identified for arsenic, chromium, manganese, strontium-90, and vanadium, occurring either as one-time detections or within a very limited area. The RCRA corrective measure study (DOE/RL-96-66), which included numerical modeling and a risk assessment, identified only the iodine-129 and tritium plumes for further evaluation. The corrective action evaluation considered only the no action and institutional control alternatives because of the widespread nature of the plumes, the low concentrations over much of the plume area, and the lack of a suitable treatment technology. Also, because of its 12.3-year half-life, tritium is expected to decay to acceptable activities in the next 50 years. No other actions are expected at this time.

The 200 East Area was used historically for chemical separation and purification of plutonium and related waste management. For reasons of safety and security, the area was built away from the 200 West Area but 
with some redundancy of function. The B Plant and PUREX Plant were the major processing facilities in the 200 East Area (Figure 4.9). Waste disposal facilities associated with operations included cribs, trenches, tile fields, surface impoundments, injection wells, tank farms, and landfills.

\subsubsection{B Plant}

Waste disposal facilities and single-shell tanks associated with B Plant operations are generally located in the northwestern part of the 200 East Area. The waste-disposal history associated with B Plant is similar to that of T Plant (in the 200 West Area); both plants operated over a similar time period (1944 through 1956) and used the bismuth phosphate process. High-level waste tanks in the B Plant area were used for purposes similar to the tanks in the T Plant area (see Section 4.2.2). Between 1948 and 1956,

Like T Plant, B Plant separated plutonium from irradiated fuel from 1944 through 1956. Groundwater in the area around B Plant is contaminated with iodine-129, nitrate, and technetium-99. Locally, cesium-137, cobalt-60, and plutonium also are detected.

the tanks were used to settle solids from seconddecontamination-cycle waste in a cascading system. The supernatant from the last tank in the cascade was discharged to the nearby 216-B-7A, 216-B-7B, and 216-B-8 cribs (WHC-MR-0227). From 1951 to 1956 , cell drainage waste was discharged through the cascade with the second-cycle waste. From 1951 to 1956 , the 242-B evaporator reduced the volume of first-cycle waste. However, in 1953-1954, some first-cycle waste was discharged to specific retention trenches. Waste from the original plutonium concentration facility in the 224-B building was settled in single-shell tanks before being discharged to cribs. In addition, in 1954 the 242-B evaporator discharged concentrated waste to the 216-B-37 trench (WHC-MR-0227). Thus, some of the most radioactive liquid waste was discharged to the ground rather than being stored in tanks. The waste discharged was closely related to tank waste; the tanks, however, apparently retained much of the solid waste. According to WHC-MR-0132, first-cycle waste contained $\sim 10 \%$ of the original fission activity and $1 \%$ of the plutonium. Second-cycle waste was lower in overall activity, containing less than $0.1 \%$ of the overall fission activity and $1 \%$ of the plutonium.

The 216-B-5 injection well operated from April 1945 to September 1946. The well received radioactive waste from B Plant activities, including some hotcell drainage and supernatant overflow from settling tanks. The waste was injected below the water table, resulting in radiological contamination that is still apparent more than 50 years later. Radiological contaminants associated with the facility include cesium-137, plutonium, and strontium-90. These three contaminants are restricted to the immediate vicinity of the 216-B-5 injection well because of their low mobility in groundwater and the extremely low hydraulic gradient in this area.

In 1954 and 1955, scavenged uranium recovery waste supernatant was discharged to the BY cribs and to a trench in the northern part of the 200 East Area (WHC-MR-0227). This waste supernatant contained large amounts of ferrocyanide and other chemical and radiological components from U Plant operations, This practice was discontinued because of high levels of cobalt -60 in the groundwater.

\subsubsection{PUREX Plant}

The PUREX Plant started operation in 1956, eventually replacing the REDOX Plant as the plutonium separations facility. The PUREX Plant operated from 1956 to 1972 . Following an 11-year shutdown, the PUREX Plant began operations again in 1983, which ended in December 1988 when the weapons production mission ended. A short run was started in December 1989 to stabilize material in the system. Waste from the PUREX Plant was discharged to a number of nearby cribs, ditches, and ponds. A number 
of these facilities have. RCRA monitoring requirements, and are described in the following section.

The PUREX Plant started operation in 1956, eventually replacing the REDOX Plant as the plutonium separations facility. Iodine-129, nitrate, and tritium are the major groundwater contaminants associated with this area.

\subsubsection{RCRA Facilities}

A number of facilities in the 200 East Area are monitored in accordance with RCRA. Additional detail on those facilities is warranted by the RCRA monitoring and reporting requirements.

\subsubsection{RCRA-Regulated PUREX Cribs}

The PUREX Plant has three disposal facilities for liquid waste that require groundwater monitoring in accordance with RCRA (216-A-10, 216-A-36B, and 216-A-37-1 cribs; see Figure 4.9). These cribs are no longer used and have been grouped into a single waste management area for monitoring purposes. The general stratigraphy in the vicinity of these cribs includes a discontinuous veneer of eolian sand, the Hanford formation, and the Ringold Formation (PNNL-11523). The Hanford formation consists predominantly of sand, but contains substantial percentages of gravel in the lowermost and uppermost portions of the unit. The Ringold Formation contains thick layers of river gravel intercalated with sequences of overbank silts and fine-grained paleosols.

Although the stratigraphy at all three crib sites contains the general stratigraphic sections described above, there are differences between the 216-A-10 and 216-A-36B cribs and the area near the 216-A-37-1 crib. Near the 216-A-10 and 216-A-36B cribs, the Ringold Formation contains coarse-grained fluvial Units $A$ and $E$ (WHC-SD-EN-TI-012) that are separated with the fine-grained lower mud unit. However, in the vicinity of the 216-A-37-1 crib (northeast), the lower mud unit and Unit $E$ are missing. There, the Hanford formation rests directly on Ringold Unit A.

Near the 216-A-10 and 216-A-36B cribs, the unconfined aquifer is in the saturated portion of Ringold Unit $E$ and is $\sim 22$ meters thick. Below the lower mud unit, Ringold Unit A forms a locally confined aquifer, which is $\sim 24$ meters thick. Near the 216-A-37-1 crib, the unconfined aquifer is within the lowest portion of the Hanford formation or the upper part of the Ringold Formation (Unit A). The lower mud unit is not present, so the saturated zone is entirely unconfined to the base of the Ringold Formation and the unconfined aquifer is $\sim 37$ meters thick.

Water-table maps indicate groundwater flows predominantly from the northeast to the southwest in the area northeast of the PUREX cribs because of the influence of B Pond. However, to the west and northwest, the water table is extremely flat, making estimates of flow direction and rate unreliable. Estimates from contaminant plume maps suggest that the flow direction in the area west and northwest of the PUREX cribs is to the southeast. Therefore, based on contaminant distribution patterns, groundwater from the B Pond area most likely joins groundwater from the western and northwestern 200 East Area and flows toward the south and southeast.

The $216-\mathrm{A}-10 \mathrm{crib}$ is 84 meters long, has a $V$-shaped cross-section, and is 14 meters deep. Several waste streams, collectively described as process distillate discharge, were disposed to this crib and were allowed to percolate through the soil column. The crib first received liquid waste over a 4-month period when the PUREX Plant began operations in 1956. In 1961, the crib replaced the 216-A-5 crib and received PUREX effluent continuously until 1973. Periodic discharges were received in 1977, 1978, and 1981. From 1982 to 1987 , effluent discharges resumed on a continual basis. Discharge between 1981 and 1987 averaged 100,000,000 liters per year. In 1987, the crib was taken out of service and replaced by the 216-A-45 crib. 
The process distillate waste stream to the 216-A-10 crib was characteristically acidic and contained concentrated salts. Other waste stream constituents included aliphatic hydrocarbon compounds; organic complexants; and cesium-134, cesium-137, cobalt-60, plutonium, ruthenium-103, ruthenium-106, strontium-90, tritium, and uranium (RHO-HS-SR-86-3-4Q LIQ P).

The $216-\mathrm{A}-36 \mathrm{~B}$ crib is the southern end (150 meters) of the crib originally known as the 216-A-36 crib. The original crib dimensions were 180 meters long, 4 meters wide, and 4 meters deep. A 0.15-meter-diameter perforated pipe was placed at the bottom of the crib on a 0.3-meter bed of gravel, covered with another 0.3 meters of gravel, and backfilled to grade. Ammonia scrubber distillate waste from the PUREX Plant was discharged to the crib and allowed to percolate through the soil column.

The original 216-A-36 crib received liquid effluent from September 1965 to March 1966. Many of the radionuclides that were disposed to the crib are assumed to have infiltrated near the inlet to the crib. To prevent radionuclides from reaching the water table, the northern end of the crib was used as a specific retention facility. This practice limited the amount of water discharged to the crib (RHO-HS-EV-18). To continue effluent discharges to the crib, it was divided into two sections (216-A-36A and 216-A-36B). Grout was injected into the gravel layer to form a curtain that separated the two sections. The liquid effluent discharge point was moved to the $216-\mathrm{A}-36 \mathrm{~B}$ section and the 216-A-36A section was no longer used. Discharge to the 216-A-36B crib resumed in March 1966 and continued until 1972, when the crib was temporarily removed from service. The crib was placed back in service in November 1982 and continued to operate until it was permanently taken out of service again in October 1987.

Ammonia scrubber distillate discharged to the crib consisted of condensate from nuclear fuel decladding operations, in which zirconium cladding was removed from irradiated fuel by boiling in a solution of ammonium fluoride and ammonium nitrate. Other waste stream constituents included cesium-137, cobalt- 60 , iodine-129, ruthenium-106, strontium-90, tritium, and uranium (PNL-6463).

The $216-A-37-1$ crib was originally 213 meters long, 3 meters wide, and 3.4 meters deep. A 0.25 -meter-diameter pipe was placed on 1 meter of gravel fill. The pipe was covered with gravel, a layer of plastic, and backfill material. Wastewater entered at the southeastern end of the crib, which is at a lower elevation than the northwestern end. This configuration favored infiltration at the southeastern end of the crib.

The 216-A-37-1 crib received liquid waste from March 1977 until April 1989. The waste stream included process condensate from the 242-A evaporator and included the radionuclides cesium-137, cobalt-60, plutonium, ruthenium-106, strontium- 90 , and uranium (RHO-HS-EV-18). The process condensate was regulated as a mixed waste because it contained radionuclides, spent halogenated and non-halogenated solvents, and ammonia. The estimated annual quantity of dangerous waste $(49,120$ kilograms $)$ represents the maximum annual output of evaporator process condensate during operation.

\subsubsection{216-A-29 Ditch}

This ditch is located just east of the 200 East Area. Beneath the ditch, the Hanford formation is $\sim 85$ meters thick and is predominantly composed of loose, sandy, pebble-cobble gravel and a gravelly sand with a thick layer of sand and/or muddy sand (WHC-SD-EN-TI019, WHC-SD-EN-TI-071). Ringold Formation sediment consists of Units $E$ and $A$ gravel and sand sequences, separated by the lower mud unit. The unconfined aquifer beneath the ditch lies mainly within the gravelly sediment of Ringold Unit A. The saturated thickness ranges between $\sim 2$ meters at the discharge (lower) end of the ditch to $\sim 24$ meters at the head (upper) end. The depth to the water table is $\sim 76$ meters below ground surface. 
Groundwater flows toward the west-southwest, based on nitrate and tritium plume maps and on waterlevel elevations in the monitoring wells. The tritium plume shows that the flow direction swings to the southeast as groundwater flows to the southeastern corner of the 200 East Area.

The water table beneath the ditch has steadily declined since discharges to the $\mathrm{B}$ Pond system were terminated. The change in water-table elevation resulted in a flattened water table at the head of the ditch and a decrease in gradient at the discharge end.

The 216-A-29 ditch is 2 meters wide and 2,000 meters long. Its depth varies from 1 meter at the head end (southwestern end) to 5 meters at the point of discharge. The ditch conveyed chemical waste from the PUREX Plant to B Pond from 1955 to 1986. In 1984, administrative and physical controls were implemented to avoid inadvertent discharges of hazardous waste to the ditch. All effluent sources were rerouted in July 1991, and use of this ditch for disposal was discontinued. The ditch was backfilled and revegetated for interim stabilization later that year. Prior to deactivation, the ditch received an average of 950 to 2,000 liters per minute of effluent from the PUREX Plant chemical sewer. The lower range of effluent discharges continued after production halted in 1986 because cleanout runs were performed prior to PUREX Plant decommissioning.

The ditch received effluent that contained hazardous and radiological waste. Of primary concern for RCRA were discharges of sodium hydroxide and sulfuric acid, which occurred on a daily basis from 1955 until February 1986. The waste was produced as a result of ion-exchange regeneration at the PUREX Plant.

\subsubsection{216-B-3 Pond}

216-B-3 Pond, also known as B Pond, is located east of the 200 East Area and is regulated under RCRA. The vadose zone under most of the facility is composed of Hanford formation sediment (silty sand to sand and gravel). The shallowest aquifer beneath B Pond occurs primarily within the sediment of Ringold Formation
Unit A gravel and the lower mud unit, which is discontinuous in the northern portion of this area. The water table is generally near the contact between the Hanford and Ringold formations, and the aquifer is locally confined, especially to the south and southeast of the facility (PNNL-12261). Depths to the water table range from $\sim 30$ meters northeast to $\sim 73$ meters southwest of the main pond.

Groundwater in the unconfined aquifer has historically flowed radially outward from a recharge mound. Large volumes of wastewater recharging the aquifer created the mound and significantly altered the original groundwater flow pattern of the area. As the amount of effluent discharge decreased, water levels in the Hanford formation generally declined with time. The mound is now becoming less discernible as a hydrologic feature. However, there is still a mound of high potentiometric head in the confined aquifer beneath the lower mud unit.

The B Pond system consisted of a main pond, three expansion ponds, and contiguous portions of the 216-B-3 ditches. The main pond, which began receiving effluent in 1945, was located in a natural topographic depression with a dike on the eastern margin. The pond covered $\sim 14.2$ hectares and had a maximum depth of $\sim 6.1$ meters. Three expansion ponds (216-B-3A, 216-B-3B, and 216-B-3C) were placed in service in 1983, 1984, and 1985, respectively. The 216-B-3A and 216-B-3B expansion ponds were $\sim 4.5$ hectares; the $216-\mathrm{B}-3 \mathrm{C}$ expansion pond was $\sim 16.6$ hectares. Water discharged to these ponds infiltrated into the ground and recharged the underlying aquifer. Details of the operation of these ponds are presented in DOE/RL-89-28, Rev 2. Adjacent portions of the three ditches (no longer in use) leading to the ponds are included in the system for groundwater monitoring purposes.

In 1994, the main pond and the 216-B-3 ditch were filled with clean soil, and all vegetation was removed from the perimeter as part of interim stabilization activities. Also in 1994, the expansion ponds were RCRA clean closed. In April 1994, discharges 
to the main pond ceased, and some effluents were rerouted to the 216-B-3C expansion pond via a bypass pipeline. In 1995, some of these streams were sent to the newly constructed 200 Areas Treated Effluent Disposal Facility. In August 1997, the remaining streams discharging to the 216-B-3C expansion pond were diverted to the 200 Areas Treated Effluent Disposal Facility, thus ending the operation of the B Pond system.

In the past, B Plant steam condensate and chemical waste and PUREX Plant chemical waste were discharged also to the B Pond system (primarily the main pond). Potential contaminants contained within past waste streams, which may have entered the groundwater, included tritium, aluminum nitrate, potassium hydroxide, nitric acid, sulfuric acid, and other acids (DOE/RL-89-28, Rev. 2).

\subsubsection{216-B-63 Trench}

The Hanford formation overlies the basalt beneath this trench. The Ringold Formation is absent, although remnants of reworked Ringold sediment may be incorporated into the Hanford formation. The Hanford formation consists of unconsolidated pebble to boulder gravel, fine- to coarse-grained sand, and silt (WHCSD-EN-TI-008, WHC-SD-EN-TI-012). The unconfined aquifer is $\sim 3$ to $\sim 6$ meters thick and the top of the basalt forms the base of the unconfined aquifer. The depth to the water table is $\sim 73$ meters.

The water table under the trench is nearly flat. Based on regional flow patterns, the groundwater under the trench generally flows from east to west. Paths of groundwater flow constructed on a water-table map of the area indicate that $B$ Pond to the east was the primary source of recharge beneath the trench. Groundwater levels beneath the trench are strongly affected by the dissipating $B$ Pond mound and are declining.

Trench 216-B-63, in service from March 1970 to February 1992, received liquid effluent $(378,540$ to $1,514,160$ liters per day) from the B Plant chemical sewer. The liquid effluent was a mixture of $70 \%$ steam condensate and $30 \%$ raw water, which was disposed to the western end of the open, unlined trench. Past releases to the trench included radioactive and dangerous waste. Documented hazardous discharges occurred from 1970 to October 1985 and consisted of aqueous sulfuric acid and sodium hydroxide solutions that exceeded 2.0 and $12.5 \mathrm{pH}$, respectively. Radioactive soil was dredged from the trench in August 1970, but no records of radioactive waste disposal to the trench exist. Starting in 1985, physical controls, radiation monitoring, and operating procedures were modified to avoid inadvertent discharge of chemicals or radioactive substances to the wastewater stream. Liquid effluent discharge to this trench ceased in February 1992.

\subsubsection{Single-Shell Tank Farms in 200 East Area}

The single-shell tanks that are currently storing hazardous, radioactive waste in the 200 East Area are located in waste management areas A-AX, B-BX-BY, and $C$. The stratigraphy beneath these tank farms is described in DOE/RL-93-99, Rev. 1, WHC-SD-ENAP-012, Rev. 1, and WHC-SD-EN-TA-004.

The sediment beneath Waste Management Area A-AX includes backfill, the Hanford formation, and the Ringold Formation. In the northern part of Waste Management Area A-AX, remnants of the lower mud unit of the Ringold Formation may be present below the Hanford formation. Where the lower mud is not present, the Hanford formation overlies partially cemented gravels of Ringold unit $\mathrm{A}$. The water table is $\sim 27$ meters below land surface, in Unit A. The top of the basalt defines the base of the unconfined aquifer. Beneath Waste Management Area A-AX, the saturated aquifer is $\sim 27$ meters thick.

Depth to the water table beneath Waste Management Area B-BX-BY ranges from $\sim 73$ to 80 meters.

The water table is in Hanford formation gravels in the northern part of the waste management area. In the southern part of the area, the Hanford formation is underlain by unconsolidated cobble to boulder gravel believed to be reworked Ringold Unit A that has been 
redeposited as part of the Hanford formation. This unit contains the water table in the southern two-thirds of the site (WHC-SD-EN-TA-004). The saturated aquifer thickness beneath this waste management area ranges from 1.9 to 3.7 meters. The top of the basalt defines the base of the unconfined aquifer.

The water table is $\sim 71$ to 82 meters below the surface at Waste Management Area C. The Hanford formation consists of sand, sandy gravels, and gravelly sands. The uppermost aquifer consists of gravelly muddy sand to muddy sandy gravel, which overlies basalt. Although this unit may represent the lowermost Hanford formation (WHC-SD-EN-AP-012, Rev. 1), more recent work suggests that this basal unit may be part of Ringold Unit A (WHC-SD-EN-TA004). The water table lies within these gravels, and the aquifer is estimated to be $\sim 13.8$ meters thick.

As the size of the B Pond mound decreased, the water table at the tank farms flattened. This resulted in uncertainty about the direction of local groundwater flow. Consequently long-term flow paths were, in the past, determined by the migration of contaminant plumes from the area near the PUREX Plant and from the BY cribs in the northern part of the 200 East Area. However, eventually, the direction of the groundwater flow should change back to its natural (west-to-east) direction based on basin recharge.

These waste management areas stopped receiving waste in 1980 and have been designated as RCRA facilities since 1989. Currently, the single-shell tanks are used to store radioactive and mixed waste generated by chemical processing of spent fuel rods using the tributyl phosphate, bismuth phosphate, REDOX, or PUREX processes. The types of waste added to the single-shell tanks and their general composition are discussed in WHC-MR-0132.

The tanks were constructed between 1943 and 1964 and, depending on dimensions, each held between $1,892,500$ and 3,785,000 liters. Waste management areas $B$ and $C$ each contain four smaller, 200-series tanks that hold 208,175 liters each. Waste Management Area A-AX contains 10 tanks, 5 of which are known or assumed to have leaked; Waste Management Area B-BX-BY contains 40 tanks, 20 of which are known or assumed to have leaked; and Waste Management Area $C$ contains 16 tanks, 6 of which are known or assumed to have leaked.

The single-shell tanks received mixtures of organic and inorganic liquids containing radionuclides, solvents, and metals that were originally discharged as alkaline slurries. Waste management operations have mixed various waste streams from numerous processes conducted in the processing of spent fuel rods. Thus, the contents within each tank are difficult to determine. The situation is further complicated by subsequent chemical reactions, degradation, and decay of radionuclides. The radionuclide and chemical inventory of the single-shell tanks is summarized in WHCSD-WM-TI-565, Rev. 1; historical operations at the tank farms are summarized in WHC-MR-0227 and WHC-MR-0132. In the case of Waste Management Area B-BX-BY, source determination for the singleshell tanks is further complicated because tank waste was discharged to nearby cribs, unlined specific retention trenches, unlined ditches, French drains, and ponds.

Tank waste exists in the form of saltcake and sludge, which is the residual left after the liquids were removed. However, there are small quantities of supernatant and interstitial liquids that could not be removed by pumping. The waste chemistry consists of sodium hydroxide, sodium salts of aluminate, carbonate, nitrate, nitrite, and phosphate. Some hydrous oxides of iron and manganese also are present. Radionuclides such as cesium-137, strontium-90, technetium-99, and actinide elements such as neptunium, plutonium, thorium, and uranium constitute the principal radioactive components. Some of the single-shell tanks also contain ferrocyanide or organic salts.

\subsubsection{Low-Level Waste Management Areas in 200 East Area}

Low-Level Waste Management Area 1 is located in the northwestern corner of the 200 East Area and includes all of the 218-E-10 burial ground. Low-Level 
Waste Management Area 2 is located in the northeastern corner of the 200 East Area and includes all of burial ground 218-E-12B.

Low-Level Waste Management Area 1 is underlain by the Hanford and Ringold formations. The depth to the water table ranges between 71 and 87 meters below ground surface and the aquifer is $\sim 3$ to $\sim 8$ meters thick. The unconfined aquifer is contained in sand and gravel of the Hanford formation and in sediment of the Ringold lower mud unit and Ringold Unit A. Determining the direction of groundwater flow in the area of Low-Level Waste Management Area 1, using only water-level data from the monitoring wells, is unreliable because the gradient in this area is extremely low. A better estimate of the flow direction can be inferred from contaminant plume maps, which suggest that the general direction of flow is to the northwest.

Low-Level Waste Management Area 2 is underlain by the Hanford formation. The unconfined aquifer beneath this area is contained in the sand and gravel of the Hanford formation, which directly overlie the basalt. The water table is 57 to 74 meters below the surface and aquifer thickness ranges from 0 to $\sim 2$ meters. In this area, the groundwater flows primarily from east to west based on water-table contours of the regional flow system. The basalt high north and east of Low-Level Waste Management Area 2 and the presence of the $B$ Pond groundwater mound affect flow.

The southern portion of Low-Level Waste Management Area 1 is currently active, while the northern portion is for future expansion. The active area measures 22.9 hectares, and the area for future expansion measures 15.3 hectares, for a total area of 38.2 hectares. Disposal activities began in 1960 and continue to the present. Materials placed in this facility are primarily dragoff waste, failed equipment, and mixed industrial waste from the PUREX Plant, B Plant, and N Reactor.

Low-Level Waste Management Area 2 has a total area of 70.1 hectares and has been in use since 1968 . The majority of the waste is in the eastern half of the burial ground and consists primarily of miscellaneous dry waste and submarine reactor compartments. Parts of two trenches contain transuranic waste.

\subsubsection{Liquid Effluent Retention Facility}

The stratigraphy beneath this facility, located northeast of 200 East Area, is primarily composed of gravel-dominated sediment of the Hanford formation with occasional interbedded fine-grained zones. Isolated remnants of Ringold Unit A exist locally between the Hanford formation and the underlying basalt bedrock (WHC-SD-EN-TI-012, WHC-SD-EN-TI-019, WHC-SD-EN-TI-071, WHC-SD-EN-TI-290). Thin (a few meters or less) pockets of Ringold Formation occur to the south.

The unconfined aquifer beneath this facility is predominantly composed of sediment of the Hanford formation. The unconfined aquifer is thin, ranging from 0.2 to 2.1 meters. The depth to the water table is $\sim 60$ meters below ground surface. The top of the basalt defines the base of the unconfined aquifer. The direction of groundwater flow is generally to the southwest based on the regional water-table contours. However, using only water-level data from wells monitoring the facility, the local direction of flow is inferred to be westward.

The Liquid Effluent Retention Facility consists of three $24,600,000$-liter surface basins on a 15.8-hectare site northeast of the 200 East Area. The three basins were constructed of two composite liners, a leachate collection system between the liners, and a floating cover. The fourth basin is excavated but is not completed and will not be used.

This facility serves as temporary storage for evaporator process condensate that is subsequently treated in the 200 Areas Effluent Treatment Facility. The 242-A evaporator is used to substantially reduce the quantity of waste stored in the double-shell tanks, and the effluent is discharged to cribs in the 200 East Area. The evaporator was shut down when hazardous waste was found in the effluent stream but was restarted on April 14, 1994. Primary constituents detected in the effluent stream from the 242 -A evaporator were 
ammonium, acetone, aluminum, 1-butanol, 2-butanone, cesium-137, ruthenium-106, strontium- 90 , and tritium.

\subsubsection{Areas Treated Effluent Disposal Facility}

This facility is a non-RCRA disposal site built to provide an infiltration area for treated liquid effluent from the generating facilities in the 200 Areas. The facility is located $\sim 600$ meters east of the $216-B-3 C$ expansion pond. In operation since June 1995, the facility disposes steam condensate and other clean water to the soil column. Some of the streams formerly discharged to the $216-\mathrm{B}-3 \mathrm{C}$ expansion pond were rerouted to this facility in 1995, and the remainder of the 216-B-3C expansion pond streams were diverted to this facility in August 1997.

\subsection{Area}

Beneath the 400 Area, located in the south-central portion of the Hanford Site, the Hanford formation consists mainly of the sand-dominated sediment. The depth to the water table ranges from $\sim 45$ to 50 meters, near the contact between the Hanford and Ringold formations. Sediment of the Hanford formation dominate groundwater flow because of their relatively high permeability compared to that of the Ringold Formation. In descending order, the Ringold Formation consists of gravelly sands, sandy gravels, silty sands, and fluvial gravels and overbank and lacustrine silt and clay. The saturated aquifer thickness is $\sim 140$ meters. Groundwater flows generally from west to east across the 400 Area. Additional details concerning the geology and the construction of wells near the 400 Area facilities are provided in WHC-EP-0587.

The 400 Area is the location of the Fast Flux Test Facility, a liquid sodium cooled reactor (Figure 4.10). The reactor is on standby pending a restart decision for the production of medical isotopes. Other facilities in the area include the $4608-\mathrm{B} / \mathrm{C}$ ponds and water supply wells. Assessment efforts associated with the CERCLA 300-FF-2 Operable Unit will extend to include groundwater contamination in the 400 Area.

\subsection{Process Ponds}

The $4608 \mathrm{~B} / \mathrm{C}$ ponds (also called the 400 Area process ponds), located north of the 400 Area perimeter fence, are unlined infiltration ponds that receive wastewater from the 400 Area facilities. The waste stream consists primarily of cooling water and intermittent small contributors (e.g., sinks and drains). The facility is designated as a WAC-173-216 discharge permit site, and the permit was issued on August 1, 1996, and modified on February 10, 1998.

\section{Sources of Contamination in $\mathbf{4 0 0}$ Area}

Facilities and sources of contamination in the 400 Area include

$$
\begin{aligned}
& \text { - Fast Flux Test Facility } \\
& \text { - process ponds } \\
& \text { - sewage lagoons. }
\end{aligned}
$$

Nitrate is the only contaminant in groundwater originating in the 400 Area. Tritium also is present from upgradient sources.

\subsubsection{Water Supply Wells}

The water supply for the 400 Area, including the drinking water, is provided by wells completed in the Hanford/Ringold aquifer system. The original water supply wells (499-SO-7 and 499-SO-8) were completed near the top of the aquifer. When tritium contamination was detected in the water supply, an additional well (499-S1-8J) was drilled in the lower unconfined aquifer in 1985 to reduce the tritium concentration below the 4-mrem/yr effective dose equivalent standard. Well 499-S1-8J is now the primary water-supply well, and wells 499-S0-7 and 499-S0-8 are maintained for backup supply and emergency use. 


\subsection{Area}

The 600 Area includes all of the Hanford Site that is not within other designated operational areas. Facilities in the 600 Area include the Nonradioactive Dangerous Waste Landfill and the Solid Waste Landfill. These two landfills are known collectively as the Central Landfill. They are in the central part of the Hanford Site southeast of the 200 East Area. Other facilities include the former Gable Mountain Pond and the 618-10 Burial Ground and 316-4 Crib.

\subsubsection{Central Landfill}

The Nonradioactive Dangerous Waste Landfill and Solid Waste Landfill are located $~ 5.5$ kilometers southeast of the 200 East Area and are underlain by $\sim 180$ meters of sediment from the Hanford and Ringold formations. Beneath these landfills, the Hanford formation is dominated by sand near the surface and gravel in the deeper portions of the formation. Thin,

\section{Sources of Contamination in 600 Area}

Facilities and sources of contamination in the 600 Area include

\section{Solid Waste Landfill}

Nonradioactive Dangerous Waste Landfill (RCRA unit)

- Gable Mountain Pond

618-10 burial ground

- 316-4 crib

- all areas of the Hanford Site not within other designated areas.

Groundwater contamination associated with facilities in the 600 Area is not widespread. Contaminants include chromium, hydrocarbons, strontium-90, and uranium. discontinuous, silt layers, as well as clastic dikes, are common in the upper part of the formation (WHCEP-0021). The Ringold Formation consists of the upper Ringold; Ringold Units A, B, C, and E; and Ringold lower mud. The upper Ringold contains a thin, silt-rich layer that may be locally confining (WHC-EP-0021). The Ringold lower mud is relatively continuous in this area and acts as a local confining unit to Ringold Unit A that overlies the basalt. Additional details concerning the geology and the construction of wells near these facilities are provided in WHC-EP-0021 and PNL-6852.

The depth to the water table ranges from $\sim 38$ to 41 meters below ground surface, in the gravel of the Hanford formation. The saturated thickness above the top of the basalt is $\sim 140$ meters. The hydraulic gradient is very low in this vicinity because of a zone of very high transmissivity beneath the landfills that extends to the northwest beneath the 200 East Area (see Figure 3.9).

The movement of tritium and nitrate plumes, which originate in the 200 East Area and pass beneath the landfills, indicate that the principal direction of groundwater flow is $\sim 125$ degrees east of north (Section 17.0 in DOE/RL-91-03), a direction that has remained relatively constant since 1990 . The direction of groundwater flow based on water-level elevations range between $\sim 96$ and $\sim 139$ degrees east of north. These directions are uncertain because of the low gradient.

The Solid Waste Landfill is a 27-hectare facility monitored in accordance with WAC 173-304. Beginning operation in 1972, the Solid Waste Landfill received principally solid waste, including paper, construction debris, asbestos, and lunchroom waste. In addition to the solid waste, $\sim 3,800,000$ to $5,700,000$ liters of sewage were disposed in trenches along the eastern and western sides of the Solid Waste Landfill between 1975 and 1987, and 380,000 liters of Hanford Site bus/garage washwater were disposed in three short trenches along the western side of the site between 1985 and 1987 . 
The Nonradioactive Dangerous Waste Landfill is a 4-hectare, inactive, RCRA-regulated landfill. It received waste from 1975 to 1985 that included asbestos, miscellaneous laboratory waste, solvents, paints, sewage, sulfamic and other acids, batteries and battery acid, and mercury. The Nonradioactive Dangerous Waste Landfill continued to receive asbestos waste until 1988 (DOE/RL-90-17).

\subsubsection{Gable Mountain Pond}

This pond, located south of Gable Mountain, received 200 East Area liquid waste from 1957 until it was decommissioned in 1987. The surface area of the pond reached at least 28 hectares during its operational period (RHO-ST-38). The pond is currently dry and covered with fill. Discharge to the pond included cooling water and condensate from a variety of sources in the 200 East Area. In addition, an unplanned release from a cooling coil in the PUREX Plant contributed $\sim 100,000$ curies of fission products to Gable Mountain Pond and B Pond (RHO-ST-38). The primary radiological constituents discharged to the pond were strontium-90, cesium-137, and ruthenium-106.

\subsubsection{8-10 Burial Ground and 316-4 Crib}

The burial ground and adjacent crib are southeast of the 400 Area, adjacent to Route 4S. The burial ground operated from 1954 to 1963 and received a variety of low-to high-concentration radioactive waste, mostly composed of fission products with some plutonium contaminated material (DOE/RL-96-42). The waste was disposed in caissons and trenches and may have included liquid and solid waste. The crib began receiving waste solutions containing uranium in 1948 and continued to periodically receive hexone, nitrate, and organic waste through at least 1962 (DOE/RL-96-42). This site was investigated as part of a CERCLA limited field investigation for the 300-FF-2 Operable Unit (DOE/RL-96-42).

\subsection{Area}

The unconfined aquifer in the 300 Area consists of Hanford formation gravel and sand and Ringold Formation gravel and sand with varying amounts of silt and clay (WHC-SD-EN-TI-052). The water table in most of the 300 Area is within the Hanford formation. West and north of the 300 Area, the water table is in Ringold Unit $\mathrm{E}$. Channeling in the top of the Ringold Formation (PNL-2949, WHC-SD-EN-TI-052) is a factor in controlling groundwater movement in the unconfined aquifer. The Ringold lower mud unit is below the unconfined Ringold gravel and forms a local confining unit for thin gravel deposits that lie directly above the basalt. A shallower mud unit is present in the western part of the 300 Area.

The depth to the water table beneath the 300 Area ranges from less than 1 meter near the Columbia River to $\sim 18$ meters farther inland. Detailed information on the hydrogeology of the 300 Area is provided in WHC-SD-EN-TI-052. The aquifer is $\sim 9$ meters thick in the western 300 Area, where the upper mud unit forms the base, and $\sim 25$ meters thick in the rest of the area.

At the $316-5$ process trenches (RCRA site), the Hanford formation is 9 to 12 meters thick and is composed of gravelly sand and sandy gravel. The Ringold

\section{Sources of Contamination in 300 Areas}

Facilities and sources of contamination in the 300 Areas include

\section{6-5 process trenches (RCRA unit)}

316-1 and 2 process ponds.

Groundwater contamination in the 300 Area includes organic compounds and uranium. 
Formation is $\sim 40$ meters thick. The upper half is interbedded sandy gravel, gravelly sand, and silty sand of Unit $E$. The lower half is composed of sandy and clayey silt of the Ringold lower mud unit, which overlies basalt at this location. The water table at the process trenches is close to the Hanford-Ringold Formation contact.

The primary influence on changes in groundwater elevation in the 300 Area is the fluctuation in Columbia River stage. These fluctuations can be correlated to changes in water-level elevations at wells as far as $\sim 360$ meters from the river (PNL-8580). During low to average river stages, groundwater in the unconfined aquifer converges at the 300 Area from the northwest and southwest, flows beneath the 300 Area in a westto-east or northwest-to-southeast direction, and eventually discharges to the river. During high-river stages, when the water table rises well above the HanfordRingold Formation contact, groundwater temporarily flows in a southwestern to southern direction.

There is an upward vertical gradient between the unconfined aquifer above the Ringold lower mud unit and the gravels beneath the lower mud unit. Confined aquifers within the basalt also display higher hydraulic heads than the overlying unconfined aquifer, indicating an upward vertical gradient.

The largest volume of waste generated in the 300 Area is associated with two source operable units. The 300-FF-1 Operable Unit contains the 316-1 south and $316-2$ north process ponds, the sanitary leaching trenches, and the $316-5$ process trenches. The 300-FF-2 Operable Unit consists primarily of waste management units that received solid waste and contaminated equipment in the northern and northwestern parts of the area and a variety of miscellaneous waste management units, including solid and liquid waste in the southern portion of the area.

The 300-FF-5 Operable Unit is the groundwater beneath the two source operable units. The extent of the 300-FF-5 Operable Unit includes all contamination that emanates from the source operable units detected in groundwater and sediments below the water table that exceeds applicable federal and state environmental requirements.

Groundwater beneath the 300 Area is potentially affected by contamination flowing in from several source areas in addition to the 300-FF-1 Operable Unit. The other potential sources are the following:

- The 300-FF-2 Operable Unit includes buried waste and contaminated vadose soils in the portion of the 300 Area that is not part of the 300-FF-1 Operable Unit. The 300-FF-2 Operable Unit also includes waste and contaminated vadose soils in the 400 Area and in select portions of the 600 Area and addresses groundwater not covered by the 300 -FF- 5 Operable Unit.

- The southeastern portion of the tritium plume that emanates from the 200 Areas (200-PO-1 Operable Unit).

- The 1100-EM-1 Operable Unit associated with the Hom Rapids Landfill, which contains a plume of trichloroethylene that is migrating in the direction of the 300 Area.

Activities in the 300 Area have been historically related to various research activities and the processing of uranium into fuel elements for the reactors (Figure 4.11). In addition to the fuel-fabrication processes, many technical support, service support, and research and development activities related to fuel fabrication were carried out. Fuel fabrication activities ended in 1987. During fuel fabrication, uranium was disposed to the process ponds and trenches in dissolved and particulate forms.

The 316-5 process trenches, in operation until December 1994, have RCRA requirements for groundwater monitoring. The trenches are unlined and were constructed in 1975. From 1975 until shutdown of fuel fabrication activities in 1987 , and other operations in 1988, the trenches were used for the disposal of most liquid waste generated in the 300 Area. The liquid waste was known or suspected to include ammonium, chlorinated hydrocarbons, metals, nitrate, and uranium (PNL-6716). The discharge rate reached a maximum of $\sim 7,600$ liters per minute. After 1988 , 
the wastewater consisted of cooling water with small quantities of non-hazardous maintenance and process water. In July 1991, the trenches were modified as part of an expedited response action. The modification of the trenches involved removing bottom sediment from the inflow end of each trench and placing it at the opposite end of the trenches behind a berm. The trenches were used on an alternating, as-needed basis. The western trench became inoperable on November 20, 1992. Subsequently, the eastern trench received all discharges. The average discharge to the eastern trench was $\sim 850$ liters per minute in the latter years of operation. In December 1994, all discharges to the trenches were terminated.

The 316-1 and 316-2 process ponds were the main facility for the disposal of uranium contaminated wastewater until 1975 when the $316-5$ process trenches were constructed and put into use.

\subsection{Richland North Area}

The Richland North Area is located in the southern part of the Hanford Site. Although this area is not formally defined, it includes the former 1100 and 3000 Areas, that part of the 600 Area south of the 300 Area, and parts of nearby Richland between the Yakima and Columbia Rivers. The 1100 Area was transferred from DOE to Port of Benton ownership in 1998.

The unconfined aquifer beneath the Richland North Area occurs within the sand and gravel of the Hanford and Ringold formations. The depth to water ranges from less than 2 meters along the riverbank and adjacent to the Horn Rapids Business Center to $\sim 30$ meters beneath the Richland Landfill. Aquifer thickness ranges from $\sim 7$ to 32 meters. Silty clays overlying the Saddle Mountains Basalt form the aquifer base. Silt and clay lenses in the eastern part of the Richland North Area may result in local, semiconfined to confined conditions within the aquifer. Perched water is found locally in north Richland during the summer irrigation season. Additional details on the hydrogeology of the Richland North Area can be found in DOE/RL-90-18 and PNL-10094.

Groundwater beneath the Richland North Area generally flows from west to east between the Yakima and Columbia Rivers. The contours indicate that, in the vicinity of the 300 Area, groundwater converges from the northwest, west, and southwest and discharges to the Columbia River. South of the former 1100 Area, groundwater flows to the southeast.

The City of Richland's North Well Field, in the south-central portion of the Richland North Area, is the primary influence on changes in groundwater elevation in this area. The well field serves as the City of Richland's secondary drinking water supply

Most of the groundwater contamination in the Richland North area originates at upgradient sources, including offsite agriculture and industry. Contaminants include nitrate, trichloroethylene, tritium, and uranium.

system. This system consists of a settling basin and two recharge basins that recharge the unconfined aquifer with water from the Columbia River. Water is then pumped from the aquifer via the well field and dispensed to city lines for use. The well field is used primarily when the city's filtration plant is shut down for annual maintenance (January) and during peak water use in the summer months.

Historical data indicate that the ratio of recharge to discharge at this well field has varied from $2: 1$ to 4:1 (PNL-10094). Because of this net recharge, groundwater levels rose in this area and their elevations vary accordingly with the volume of recharge.

Irrigation of agricultural fields has affected water levels in the Richland North Area. Irrigation water has been supplied by the Columbia River and by shallow irrigation wells that are located near wells 
699-S42-E8A and 699-S42-E8B. Increasing water levels have been detected to the north of the irrigated fields along the southern boundary of the Hanford Site.

Facilities or activities that may affect groundwater in the Richland North Area include the City of Richland's North Well Field and recharge ponds; Siemens Power Corporation; Richland Landfill; LambWeston, Inc.; Interstate Nuclear Services; Allied Technology Group; and agricultural and residential irrigation. Additionally, one new heavy industry is operational and several are planned $\sim 1$ to 2 kilometers southwest of Siemens Power Corporation.

The Richland North Area also contains two operable units: 1100-EM-1 and 1100-EM-2. Of particular concern is the potential for future impact from these facilities and activities as well as Hanford Site operations (i.e., the tritium plume) at the city's north well field, which serves as the secondary drinking water supply system for the City of Richland. 


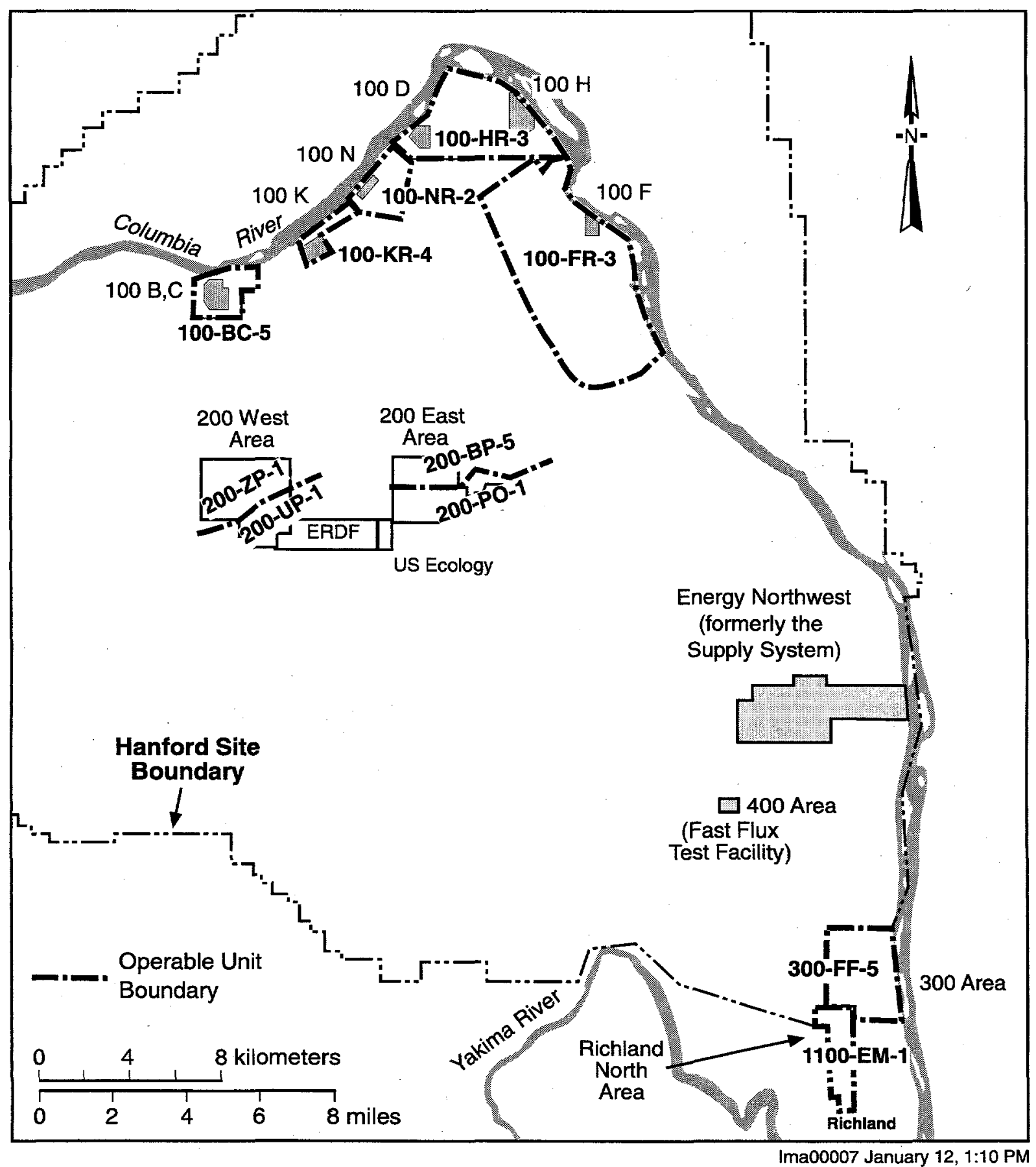

Figure 4.1. Groundwater Operable Units 


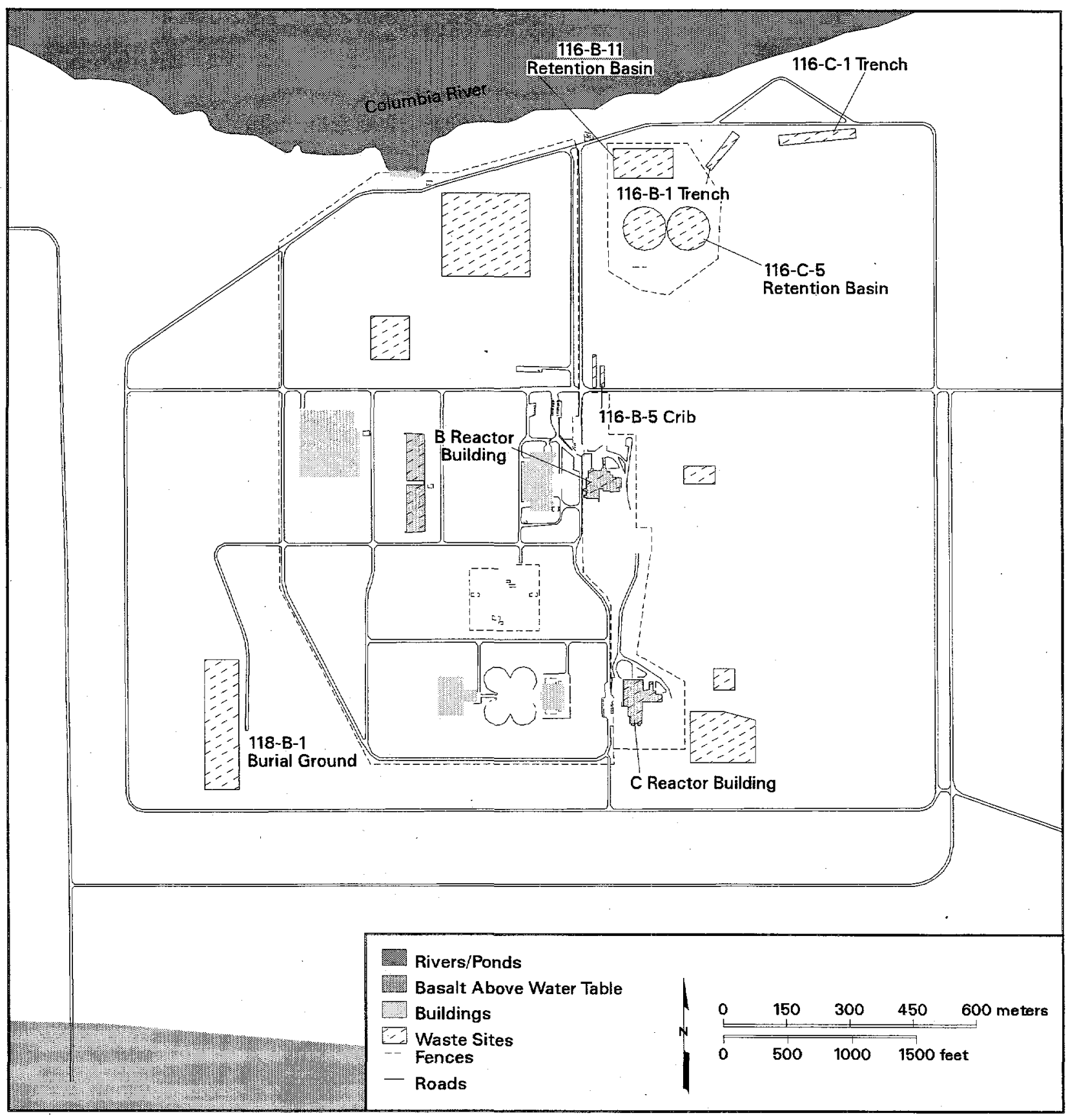

can_hart_99024 November 02, 1999 8:49 AM

Figure 4.2. $100 \mathrm{~B} / \mathrm{C}$ Area Facilities 


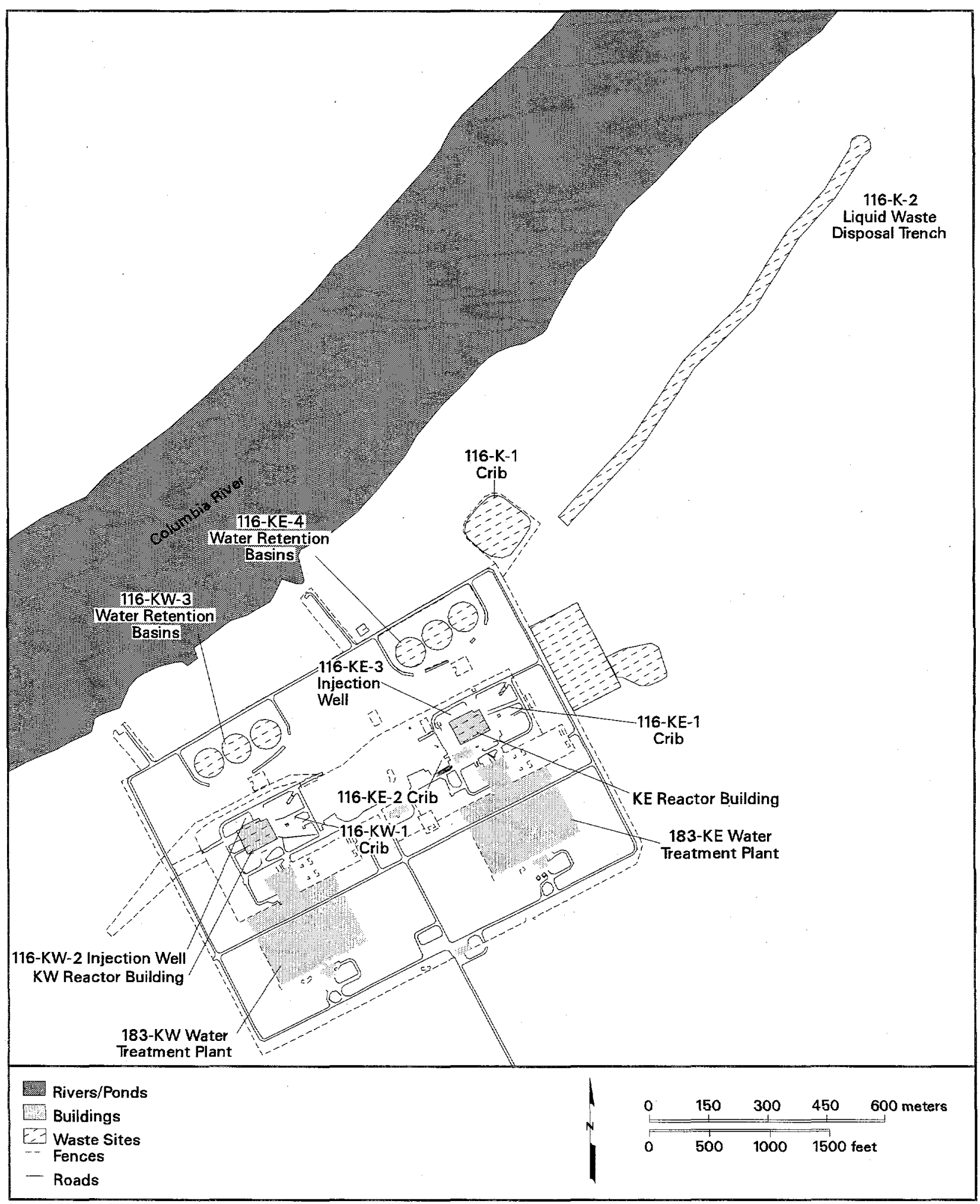

can_hart_99025 November 01, 1999 5:07 PM

Figure 4.3. $100 \mathrm{~K}$ Area Facilities 


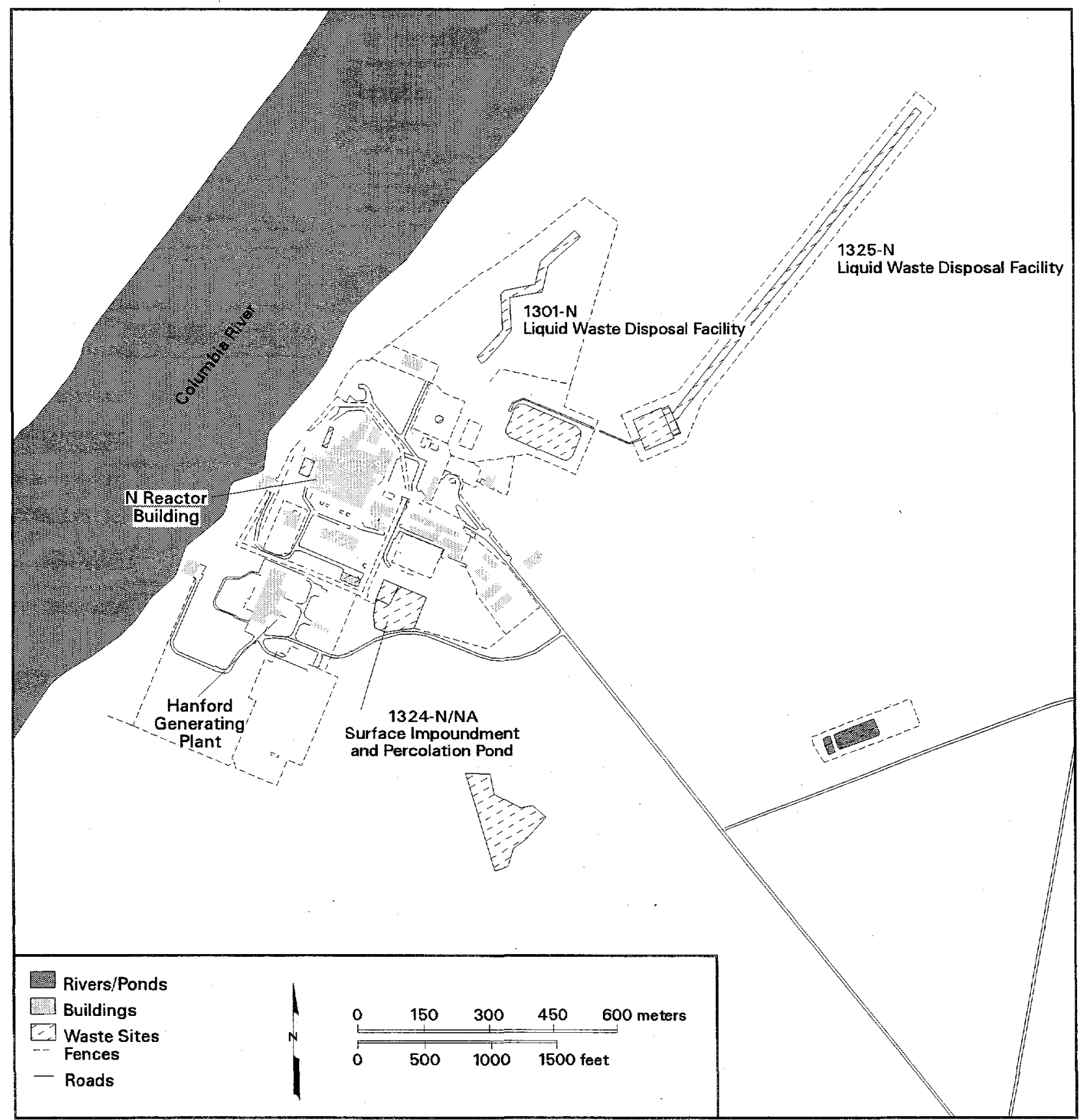

can_hart_99026 Novamber 02, 1999 8:50 AM

Figure 4.4. $100 \mathrm{~N}$ Area Facilities 


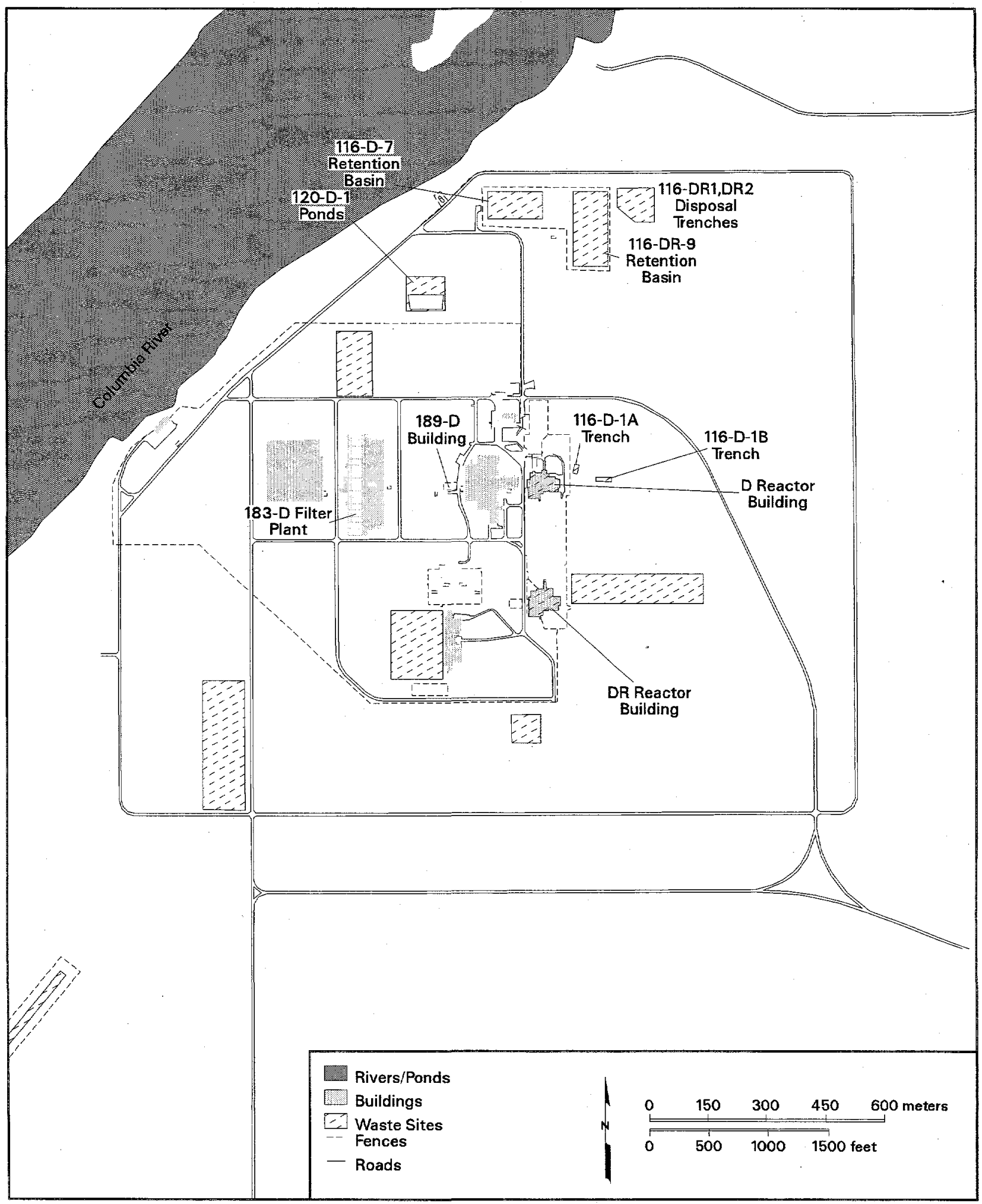

can_hart_99027 Novamber 02, 1999 8:52 AM

Figure 4.5. $100 \mathrm{D}$ Area Facilities 


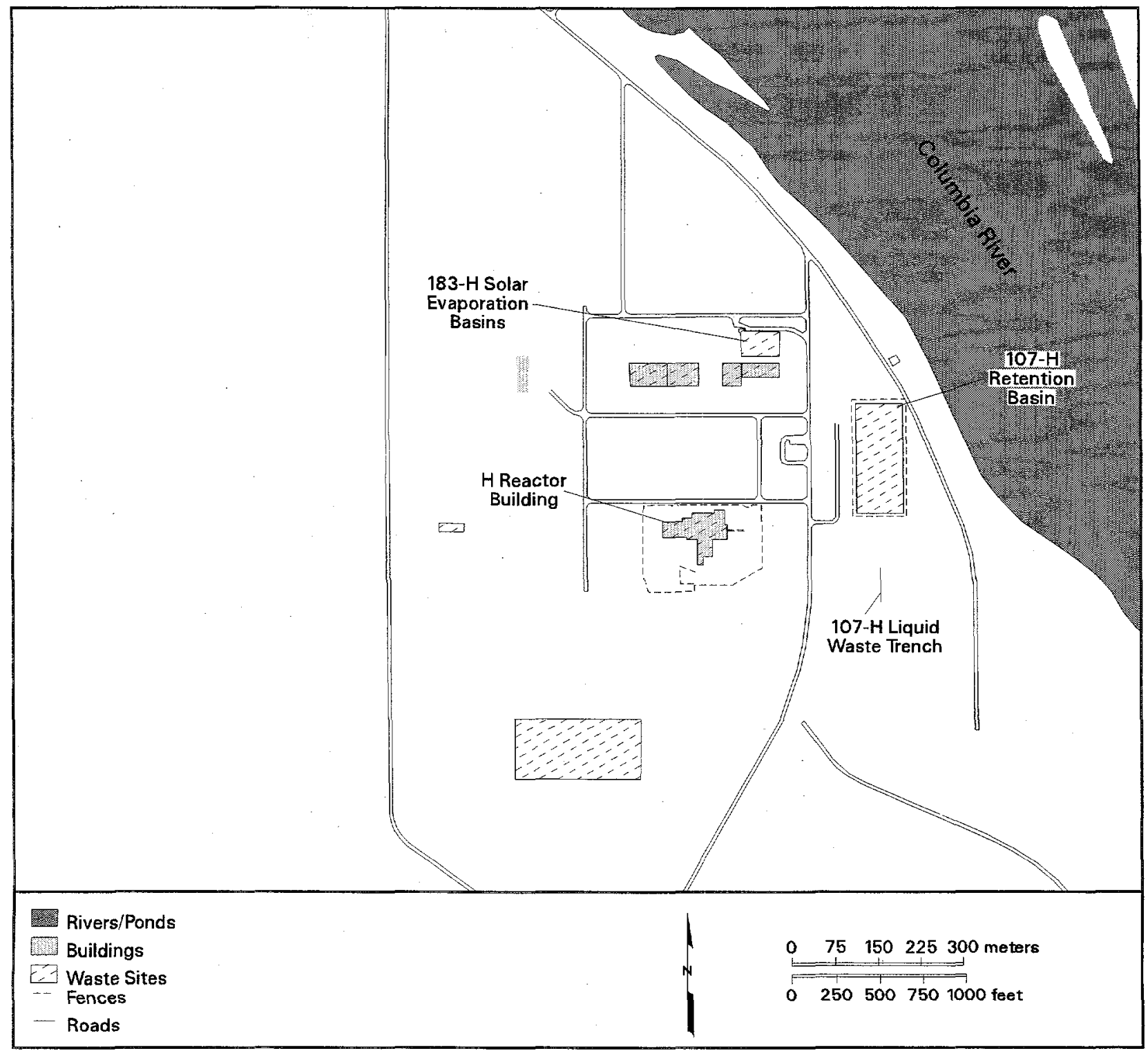

can_hart_99028 November 01, 1999 5:12 PM

Figure 4.6. $100 \mathrm{H}$ Area Facilities 


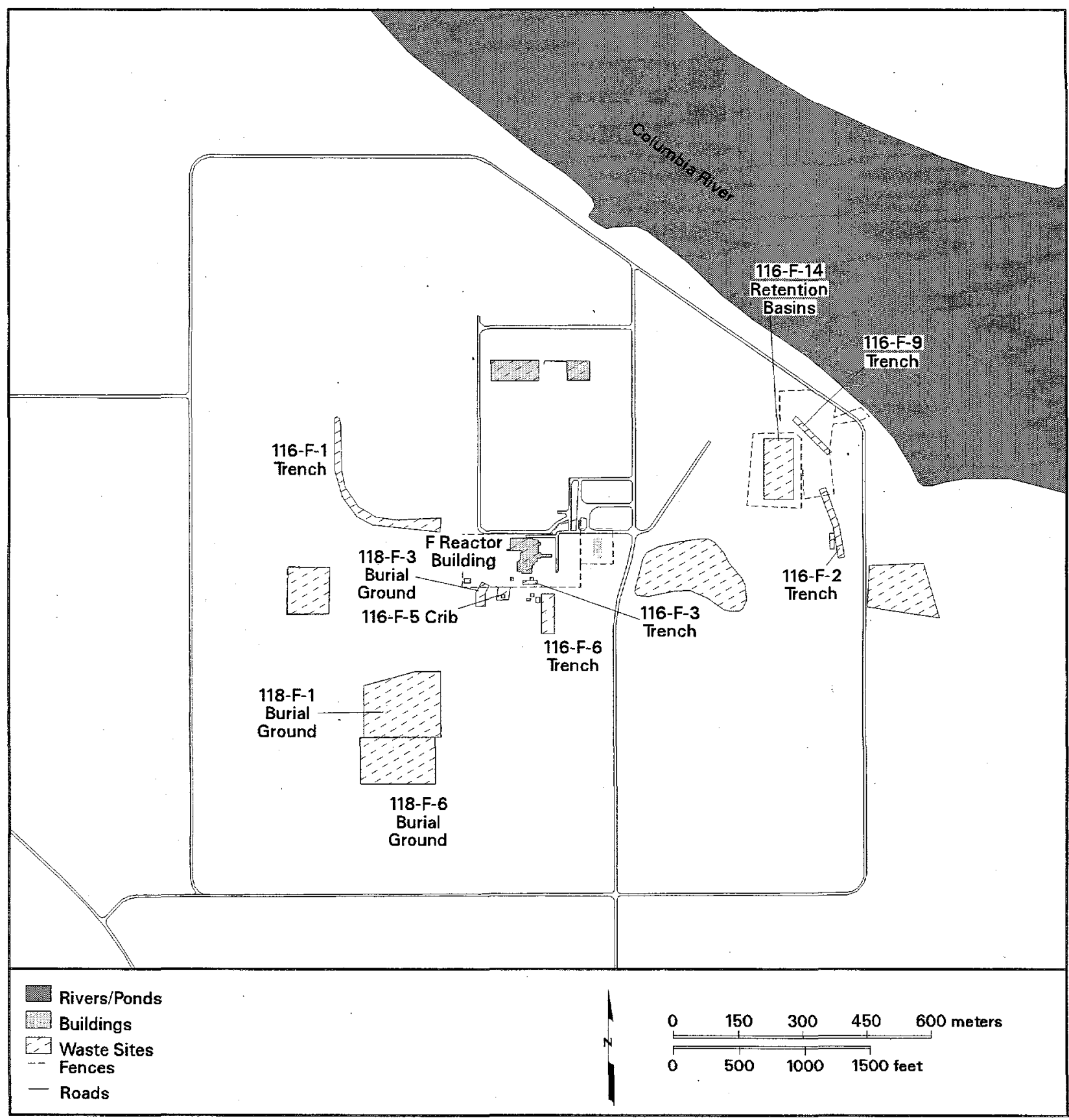

can_hart_99029 November 01, 1999 5:13 PM

Figure 4.7. $100 \mathrm{~F}$ Area Facilities 


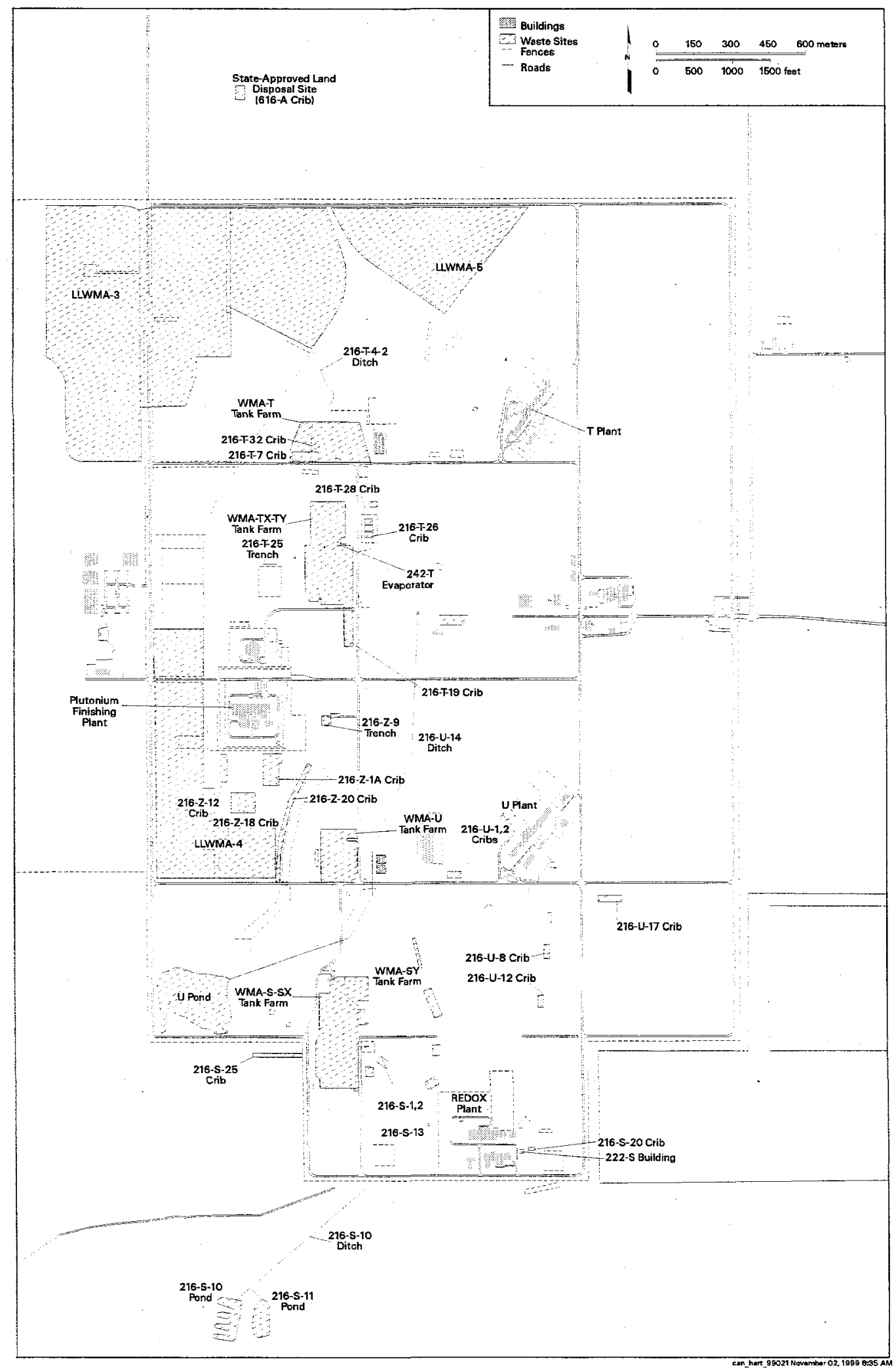

Figure 4.8. 200 West Area Facilities 


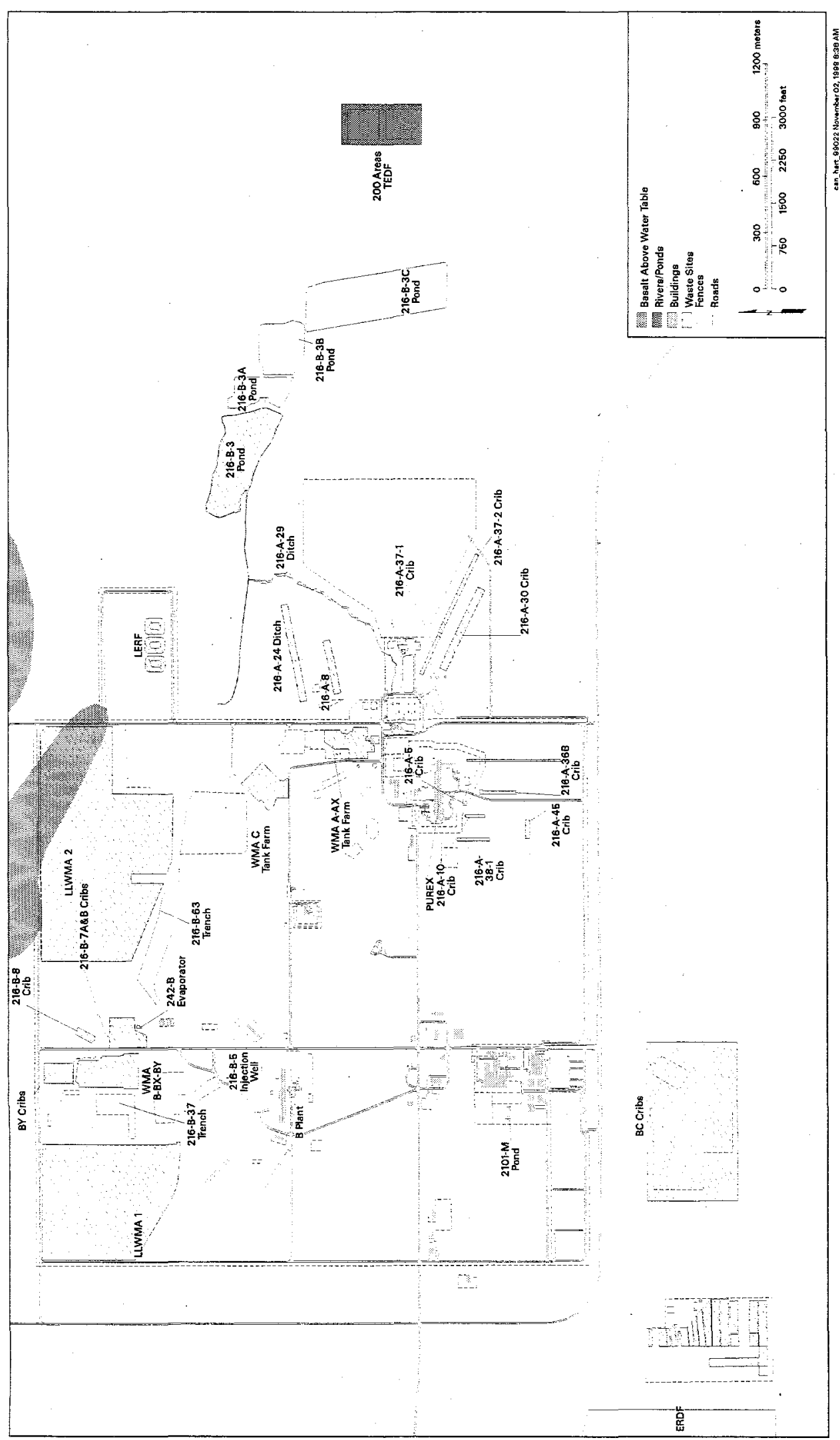



14. $4.39=$ 


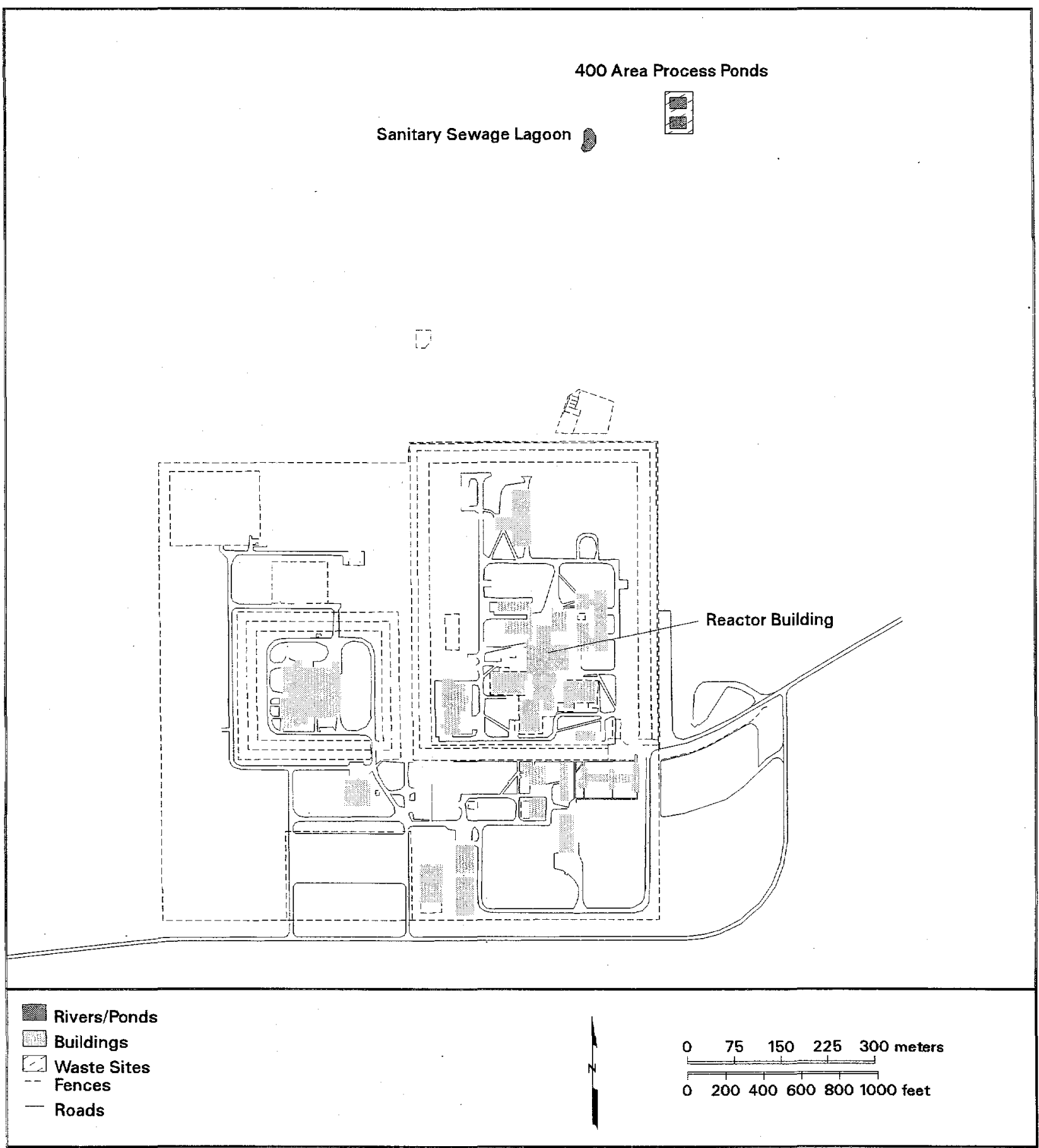

can hart 99030 November 01, 1999 5:14 PM

Figure 4.10. 400 Area 


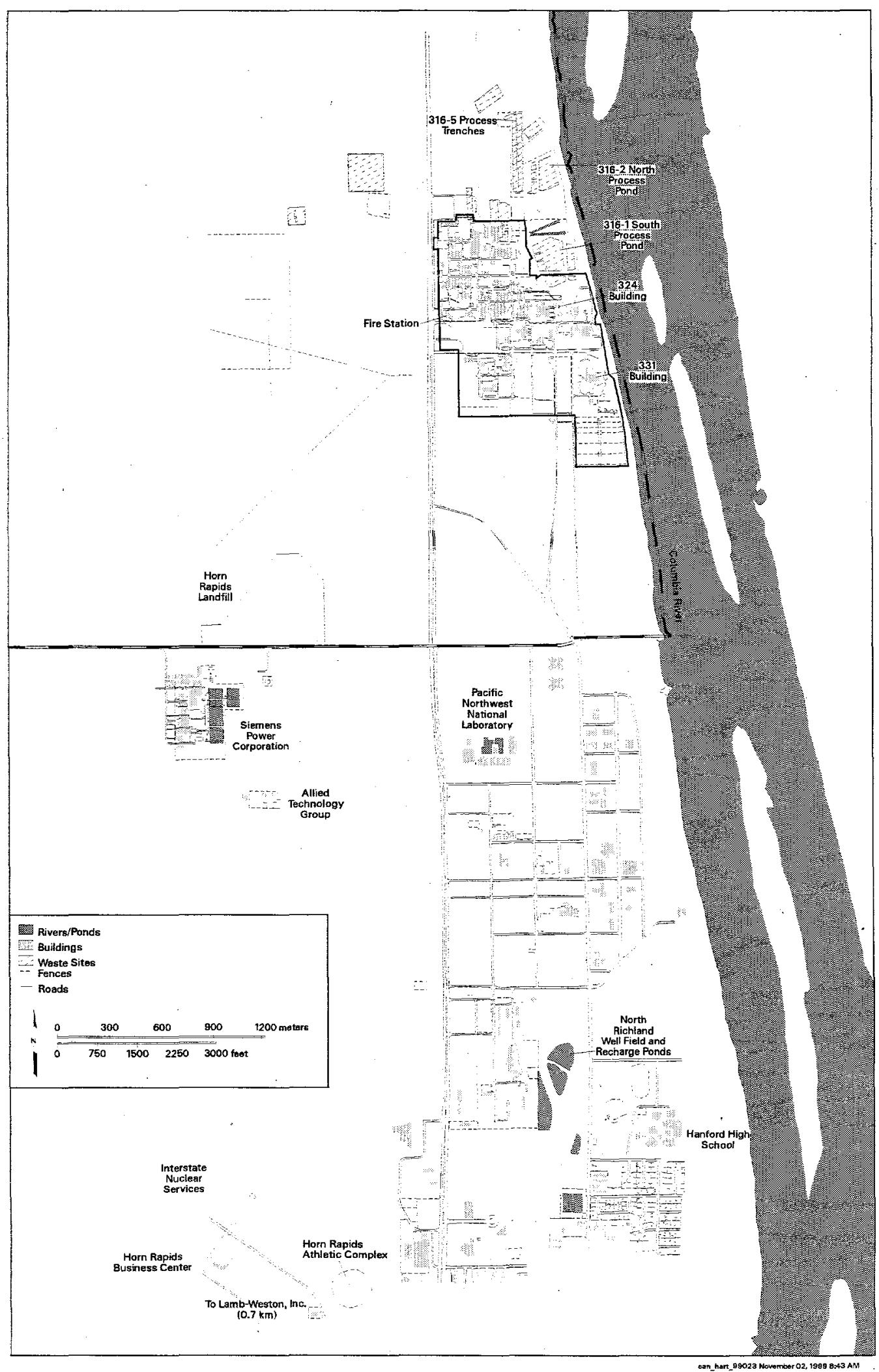

Figure 4.11. 300 and Richland North Areas 
-

- 


\subsection{Groundwater Monitoring}

Groundwater monitoring at the Hanford Site is performed to track changes in the extent of existing contamination, to identify any new impacts of contamination on groundwater, to provide data needed to support groundwater remediation, and to evaluate the effectiveness of remedial activities (PNNL-11989). The selections of wells, constituents, and sampling frequencies are based on knowledge of waste disposal practices and inventories (PNL-6456), regulatory requirements (e.g., RCRA, CERCLA), proximity to disposal areas, contaminant mobility, and site hydrogeology.

\subsection{Water-Level Monitoring}

Water-level data are used to determine the patterns of groundwater flow and to evaluate the dynamics of the groundwater flow system in the Hanford/ Ringold aquifer system and the upper basalt-confined aquifer system. Water levels are measured in selected wells in the Hanford/Ringold aquifer system beneath the Hanford Site and outlying areas. In the past these measurements were made in June, but beginning in 1999 they were made in March to decrease the effects of high river stage on the water-table map. The purpose of the measurements is to monitor changes in water-table elevations that affect the direction and linear velocity of flow and transport of contaminants. More frequent measurements are made at selected wells to monitor temporal variations. The March measurements are used to produce an annual water-table map

Maps showing elevation contours for the water table are used to determine the direction groundwater flows through the unconfined aquifer. Water generally flows from areas with high water-level elevations to areas of low water-level elevations. of the Hanford Site. Water-table maps of the unconfined aquifer have been prepared semiannually or annually since 1944 . The sitewide water-level monitoring plan is presented in PNNL-13021.

Groundwater monitoring plans for individual RCRA sites specify requirements for water-level monitoring. These data aid in determining the direction of flow beneath the RCRA units and in determining if the monitoring network is adequate. The frequency of water-level measurements varies from monthly to annually, depending on such factors as the hydraulic gradient beneath the site and the temporal variability of water levels.

Groundwater monitoring plans for individual CERCLA sites specify requirements for water-level monitoring. These data aid in determining the direction of flow beneath the CERCLA sites and the area affected by withdrawal and/or injection associated with pump-and-treat operations. The frequency of waterlevel measurements varies from hourly to annually, depending on the local gradient, temporal variability of water levels, and site requirements.

Water levels are also measured in confined units in the Ringold Formation and in the upper basaltconfined aquifer system to monitor changes in the potentiometric surface. These changes can affect the direction, flow rate, and potential for hydraulic interaction with the overlying Hanford/Ringold aquifer system. These measurements are part of sitewide monitoring (PNNL-13021).

In addition to the water-level measurements described above; where possible, water levels are measured prior to each groundwater-sampling event. 


\subsubsection{Monitoring Network}

Annual measurements are made in wells completed in the Hanford/Ringold aquifer system on the Hanford Site, south and west of the Columbia River (see Plate 2 of PNNL-13021). The offsite and upper basalt-confined monitoring networks are shown in Figures 3.4 and 3.5 of PNNL-13021, respectively.

\subsubsection{Methods}

Procedures developed in accordance with the techniques described in American Society for Testing and Materials (1988), Garber and Koopman (1968), OSWER 9950.1, and U.S. Geological Survey (1977) are followed to measure water levels in piezometers and wells across the Hanford Site. Water levels are primarily measured with laminated steel electric sounding tapes, although graduated steel tapes are used occasionally. Measurement procedures are described in PNNL-13021.

A few wells completed in the upper basalt-confined aquifer system along the Columbia River are under flowing artesian conditions, where the potentiometric surface is above the top of the well or piezometer. For these wells, which are pressure sealed from the atmosphere, a pressure gauge or transducer is used to measure the equivalent head above the top of the surveyed reference point.

Pressure transducers and data loggers are used to measure and record heads automatically over discrete time intervals in a few wells where water levels change rapidly (e.g., near the Columbia River and near extraction or withdrawal wells). Pressure transducers and data loggers are also used to measure river stage to provide spatial and temporal control as it relates to groundwater levels near the river. River-stage monitoring stations, which support CERCLA activities, are located at the $100 \mathrm{~B} / \mathrm{C}, 100 \mathrm{H}, 100 \mathrm{~N}, 100 \mathrm{~F}$, and 300 areas.

\subsubsection{Data Quality}

The procedures developed for determining water levels were designed to ensure the integrity and representativeness of the data. Interpretation of water-level data assumes that the measurements are temporally and spatially representative. However, various sources of error and uncertainty that limit the accuracy of the data and affect their representativeness include the following:

- changes in the water table or potentiometric surface during the period of time in which waterlevel measurements are made

- changes due to barometric pressure fluctuations

- vertical gradients over the screened interval in a well

- deviations of the well from vertical

- errors in surveyed reference-point elevations

- limits of measuring device precision and accuracy

- measurement transcription errors.

To reduce the effect of seasonal and other longterm water-level changes, water-level measurements for the Hanford Site water-table map are made within a 1-month period (March). The most significant short-term water-level changes are in wells influenced by fluctuations in Columbia River stage. These shortterm water-level fluctuations in wells introduce transient effects in representing the water-table surface adjacent to the river. To reduce the significance of this effect, wells within a given area near the river are measured within one day.

The effect of open-interval depth below the water table on water levels depends on the vertical gradient in a given area. For the scale and contouring interval of the site map and of most local maps, any well screened within 10 meters of the water table is assumed to be acceptable. The remaining sources of error listed 
above generally are only significant in areas of very low horizontal gradients (e.g., the 200 East Area). In some of these areas, water-level data alone are insufficient to determine the direction of groundwater flow, and other information (e.g., contaminant plume configuration, regional flow patterns) must also be considered. The sources of error listed above are discussed in more detail in PNNL-13021.

Water-level data are screened for outliers (obvious errors and extreme data) before producing water-table maps. Outliers are not plotted on most water-table or potentiometric surface maps but are usually included on trend plots unless they are beyond the limits of the plot scale. Data collected from data-logger and pressuretransducer systems are compared to manual measurements to evaluate and correct for transducer drift.

\subsubsection{Interpretive Techniques}

Water-level elevation is determined by taking the surveyed elevation of a reference point on the well casing and subtracting the depth to water measured from that point. Water-level elevations are reported using the North American Vertical Datum of 1988 (NAVD88) (DOE/RL-94-111). Until fiscal year 1998, the Hanford Site water-table map reported elevations using the National Geodetic Vertical Datum of 1929 (NGVD29). NAVD88 elevations are $\sim 1$ meter higher than NGVD29 elevations in the vicinity of the Hanford Site. Many of the wells used to construct the water-table map were surveyed earlier and have reference point elevations in NGVD29. Elevations were converted to NAVD88 using a software package called Corpscon (version 5.11, U.S. Army Corps of Engineers 1997), which makes use of the VERTCON software program (version 2.0) developed by the National Geodetic Survey. The error associated with conversion to the NAVD88 datum using the Corpscon software is \pm 1 centimeter.

Maps showing the water-table-elevation contours for the unconfined aquifer are published annually (e.g., Plate 2 of PNNL-12086). A contour interval of 2 meters is used to show regional water-table features on the Hanford Site. To show more detail, inset maps (i.e., operational areas) use a contour interval of 0.5 meter. Water-table elevation values are posted on a base map generated with a Geographic Information System (GIS) called ARC/INFO ${ }^{\mathrm{TM}}$ (Environmental Systems Research Institute Inc., Redlands, California). The data are hand contoured by a hydrogeologist. The contours are then digitized and stored in ARC/INFO, where they are available for final map production.

Maps showing how the water table has changed over some period of time are also constructed by hand contouring the data. Additional maps are constructed that show the hydrogeologic units that intersect the water table, as well as thickness of the saturated sediments above the basalt. To generate these maps, a digital grid of the water table is electronically compared to digital grids of the hydrogeologic units and the basalt surface using a computer program called EarthVision $^{\mathrm{TM}}$ (Dynamic Graphics Inc, Alameda, California).

Because water-table elevations north and east of the Columbia River are much greater than on the Hanford Site and water-level changes are small relative to the regional water-table gradient, water-level measurements are not collected in all offsite monitoring wells each year. A contour interval of 50 meters is used north and east of the river because the watertable gradients are much steeper. Changes in the elevation of the water-table surface in this area is strongly controlled by recharge from canal seepage and applied irrigation (Drost et al. 1997). The water table in some parts of Franklin County has risen by greater than 150 meters since 1948, when the South Columbia Basin Irrigation District began operation. However, trend plots indicate that water levels in most wells in this area have reached a state of equilibrium (Drost et al. 1997) and, thus, do not change significantly, relative to the water-table gradient, from year to year.

The RCRA regulations require an annual determination of the direction and rate of groundwater or contaminant movement for sites in assessment- or compliance-level monitoring (40 CFR 265.94[b][2], 
WAC 173-303-645[10][e]). For most of the RCRA sites, the rate of flow is estimated using a form of the Darcy equation

$$
\mathrm{v}=\mathrm{Ki} / \mathrm{n}_{\mathrm{e}}
$$

where $\quad \mathrm{v}=$ average linear groundwater velocity, $\mathrm{m} / \mathrm{d}$

$\mathrm{K}=$ hydraulic conductivity, $\mathrm{m} / \mathrm{d}$

$\mathrm{i}=$ hydraulic gradient

$\mathrm{n}_{\mathrm{e}}=$ effective porosity.

Representative values of hydraulic conductivity, effective porosity, and current hydraulic gradient are used for each site. Values of hydraulic conductivity are taken from published hydrologic test results that best represent the uppermost part of the Hanford/ Ringold aquifer system. The value for effective porosity was chosen within the range of values (i.e., 0.1 to 0.3 ) typical for unconfined aquifer conditions (Bear 1979). The hydraulic gradient is estimated from the wells monitoring the RCRA facility. However, for some sites where the slope of the water table is too gentle, the local hydraulic gradient is uncertain; thus, it is estimated from the regional water-table contours.

In some cases, other methods were used to estimate the rate and direction of groundwater or contaminant flow. These methods included studying the migration of contaminant plumes and numerical flow modeling. Contaminant plume maps are used to estimate flow directions or to confirm flow directions determined by the water-table contours. Flow meters have been used in the past, but are not currently used on a regular basis.

\subsection{Contaminant Monitoring}

\subsubsection{Monitoring Network}

During a typical year, more than 600 wells are sampled for radiological and chemical constituents as part of the various Hanford Site groundwater investigations. Many of these are sampled semiannually, quarterly, or even monthly, depending on data needs. Well networks for surveillance monitoring are described and illustrated in PNNL-11989. RCRA networks are described in the site-specific groundwater monitoring plans. Monitoring networks for CERCLA are defined in records of decision or federal facility agreement and consent order change control forms.

\subsubsection{Methods}

Methods for chemical analysis of groundwater samples conform to the U.S. Environmental Protection Agency's (EPA's) Test Methods for Evaluating Solid Wastes: Physical/Chemical Methods, 3rd ed. (SW-846); Methods for Chemical Analysis of Water and Wastes (EPA-600/4-79-020), or other EPA methods, and the Annual Book of ASTM Standards (American Society for Testing and Materials 1986). The methods used for analysis of radiochemical constituents were developed by the analyzing laboratory and are recognized as acceptable within the technical radiochemical industry. Analytical methods used by the laboratories are described in Section 8.0.

Groundwater is sampled by employees and subcontractors of Pacific Northwest National Laboratory and Bechtel Hanford, Inc. Samplers followed their company's documented procedures for sampling, recordkeeping, field measurements, and sample shipment. The procedures were equivalent in most aspects.

\section{Well Sampling Objectives}

More than 600 wells are sampled each year on the Hanford Site. Objectives of monitoring include

- tracking contaminant plumes

- defecting any new contamination from active or inactive waste sites

- complying with environmental regulation

- assessing the performance of groundwater remediation. 
Most samples for metals are filtered in the field to remove particulate matter not representative of dissolved metals, and most other samples are unfiltered.

\subsubsection{Data Quality}

The chemical composition of groundwater at any location fluctuates with time because of differences in the contaminant source, recharge, and/or flow field. The range of this fluctuation can be estimated by taking many samples, but there is a practical limit to the number that can be taken. Comparison of results through time and location helps to interpret the natural variability.

Sampling techniques are designed to provide a sample that is reasonably representative of the aquifer concentration when the sample is taken. However, there are limitations to the ability to collect representative samples or even to define precisely the volume of aquifer that is represented in the sample. Proper well construction, well purging, sample preservation, and, in some instances, filtering are used to help ensure that samples are consistent and representative. Careful sample-labeling protocols, chain-of-custody control and documentation, and bottle preparation prevent many gross errors in sample results. Duplicate samples and field blanks help in assessing the sampling procedure. Section 9.0 discusses the quality control program and defines commonly used quality control terms. Results of the quality control program are described in annual reports (e.g., Appendix C of PNNL-12086).

Uncertainties are also inherent in laboratory analysis of samples. Gross errors can be introduced in the laboratory as well as during sampling, including transcription errors, calculation errors, mislabeling of results, instrument malfunction, and other errors that result from failing to follow established procedures. Often, these gross errors can be recognized because unreasonably high or unreasonably low values result. Gross errors are identified and corrected using data review procedures.
Random errors are unavoidably introduced in the analytical procedures. Usually, there are too few replicate analyses to assess the overall random error. Instruments for analyzing radioactive constituents count the amount of ionizing radiation at a detector, and background counts are subtracted. The nature of radioactive decay and the instrument design result in a random counting error, which is reported with the analytical result. Generally, sample results that are less than the counting error are an indication that the constituent was not detected. The counting methods may also result in the reporting of results that are less than zero. Although they are physically impossible, the negative values are useful for some statistical analyses.

Systematic errors may result from inaccurate instrument calibration, improper standard or sample preparation, chemical interferences in analytical techniques, or faulty sampling methodology and sample handling. Sample and laboratory protocols, therefore, were designed to minimize systematic errors. If the contracted laboratories compare favorably with other laboratories, then the level of systematic error from many sources is small enough to be acceptable.

\section{Hanford Groundwater Monitoring Project data} undergo a validation/verification process according to a documented procedure. In addition to the quality assurance/quality control checks mentioned above, data are screened by scientists familiar with the hydrogeology of the unit, compared to historical trends or spatial patterns, and flagged if they are not representative.

\subsubsection{Interpretive Techniques}

Overall sample uncertainty may be factored into data evaluation by considering the concentration trend in a given well over time. This often helps identify gross errors, and long-term trends can be distinguished from short-term variability. The interpretation of concentration trends depends on an understanding of chemical properties as well as site hydrogeology. The trend analysis, in turn, aids in refining the conceptual model of the chemical transport. 
Trend plots in groundwater annual reports generally include all the available data, including those points flagged as suspect, unless the suspect points are beyond the scale of the plot. For $\mathrm{pH}$ and specific conductance, only field measurements are plotted. Replicate values are averaged by sample date, with outliers removed. Values below the detection limit are plotted as hollow symbols.

Groundwater chemistry data are used to create maps showing the locations and concentrations of the contaminant plumes. These maps typically show the average concentration at each well for the fiscal year.

The plume maps presented in groundwater annual reports are diagrams of the groundwater chemistry at the Hanford Site based on data from all sampling programs. Most of the maps represent concentrations of contaminants at or near the water table. Although analytical data are available only for specific points where wells were sampled, contours are drawn to join the approximate locations of equal chemical concentration or radionuclide activity. The contour maps are simplified representations of plume geometry because of the map scale, lack of detailed information, variations in well completion, and the fact that plume depth and vertical extent cannot be fully represented in a two-dimensional map. Thus, the contours shown do not honor all data values at individual wells. The contours show the extent of contamination at levels of regulatory concern, such as maximum contaminant levels, interim drinking water standards, or derived concentration guides. Additional contours are shown at levels that illustrate additional features of the contaminant distribution, such as zones of high concentration or areas impacted at levels less than the interim drinking water standards or maximum contamination levels. Figures meeting these requirements are best prepared by using irregular contour intervals. In addition, groundwater contaminants are often found at values ranging over several orders of magnitude - often over short distances. In these cases, logarithmically increasing contour intervals or irregular intervals must be used to preserve the information about the distribution at both low and high concentrations.

Plume maps in the groundwater annual reports are prepared using averages of data collected at each well over the fiscal year. In some locations, contours are shown around areas having no supporting sample data from the current fiscal year. This occurs when wells are not sampled annually, or are no longer sampled at all because of changing data needs. In this case, data from the previous two fiscal years are posted on the maps using a different symbol so they can be distinguished from current data. Average values for radionuclides are calculated using reported values, including the negative values that may be reported when the sample measurement is less than the instrument background correction. Values for chemical constituents below detection limits are considered to be zero in calculating averages. In a few instances, data believed to represent gross errors in sample collection or analysis are removed from the data set before averaging. In addition, results that are reported as less than detection but at higher than normal detection levels are removed from the data set. This may occur when samples were diluted to bring another constituent into range and when certain samples are analyzed to meet specific needs of individual projects that do not require the same reporting levels. The average values are posted in the contour plots, allowing comparison of the contour interpretation to the input data set. As discussed above, not all posted values are in agreement with the contours presented.

Chemistry data from aquifer sampling tubes, located near the river shore, also are included on the plume maps. However, they do not affect contour interpretations because of uncertainties in how significantly bank storage effects may have affected the samples.

Particular situations lead to difficulties in using plume contour maps to display the extent of contamination. Rapid increases or highly variable activities of 
technetium-99 and other constituents have been observed near several of the RCRA single-shell tank waste management areas. The average values do not reflect the trends in these wells. In areas of pumpand-treat remediation, particularly where injection wells are used, the contour maps do not completely reflect the dynamics of the flow field. Average values tend to smooth out the trends induced by remediation activities.

Nitrate data are reported most commonly as nitrate or as nitrogen. The latter are converted to nitrate for trend plots, maps, and text discussion, but are reported in their original units on the data diskette included with the groundwater annual reports.

Total chromium in filtered samples is assumed to be hexavalent, the most soluble state. In some cases, analyses are performed specifically for hexavalent chromium; both types of data are included in plots and maps.

Some of the strontium-90 data are obtained through measurements of combined strontium- 89 and strontium-90. All of the strontium detected is assumed to be strontium- 90 because strontium- 89 has a much shorter half-life ( 50.5 days, compared to 29 years for strontium-90) and has decayed to undetectable levels since reactor operations ceased.

\subsection{Data Management}

Results of groundwater sampling and analysis are made accessible in the Hanford Environmental Information System (HEIS) database. This database currently resides on a Sun SPARC 20 UNIX-based multiprocessor computer. The database software is ORACLE ${ }^{\circledR}$ (Oracle Corporation, Redwood Shores, California). Analytical results from all groundwatermonitoring programs are stored in this common database, with the exception of some data collected for limited special projects that may not be directly comparable to standard data. The data are made available to federal and state regulators for retrieval.
The HEIS programmers and HEIS data owners, including the groundwater projects, ensure database integrity and data consistency through membership in the onsite HEIS configuration control board and other ad hoc groups. The majority of data are loaded into the database from electronic files provided by the analytical laboratories. This minimizes data-entry errors and reduces the cost of data management.

HEIS was formerly used to store hydraulic head measurements. However, the hydraulic head table in this database is no longer being maintained, so a project database internal to Pacific Northwest National Laboratory is being used to store water-level data taken by the groundwater project. The use of this database is intended to be temporary, while a long-term solution to the problem of archiving water-level data is sought.

\subsection{Regulatory Standards}

Contaminant concentrations in groundwater annual reports are compared to various regulatory standards that may apply under different programs. These standards include the following:

- Maximum contaminant levels are federally or state-enforceable standards for drinking water supplies. Although these levels only apply at the point of consumption of the water, they provide a useful indicator of the potential impact of groundwater contamination if water usage were to change. In addition to primary maximum contaminant levels, secondary maximum contaminant levels are set on aesthetic criteria, such as taste, rather than on health criteria. Under the Model Toxics Control Act - Cleanup regulations (WAC 173. 340), the state of Washington claims the right to require corrective actions in some instances where water supplies exceed secondary standards. Selected maximum contaminant levels are shown in Table 5.1.

- interim drinking water standards - Specific maximum contaminant levels have not been set for 
most radionuclides; however, the maximum contaminant level for gross alpha measurements, excluding uranium and radium, is $15 \mathrm{pCi} / \mathrm{L}$. For beta particles and photon activity, the maximum contaminant level is set at a $4-\mathrm{mrem} / \mathrm{yr}$ effective dose. The method of calculating the 4-mrem/yr effective dose equivalent for individual radionuclides used in the interim drinking water standards generally results in lower activities that produce higher doses than result from calculations using more current information. The interim drinking water standards will serve the purpose of providing a measure of potential impacts from groundwater contamination. Interim drinking water standards for selected radionuclides are shown in Table 5.1.

- Derived concentration guides are standards set for protection of the public from radionuclides resulting from DOE activities. The derived concentration guide is based on a $100-\mathrm{mrem} / \mathrm{yr}$ exposure standard and is the amount of an individual radionuclide that would lead to that dose through ingestion under specified intake scenarios. Because the effective dose equivalent calculations for the derived concentration guide use more current methodology, the results are not completely consistent with the interim drinking water standards. Selected derived concentration guides and the 4-mrem/yr effective dose equivalent are shown in Table 5.2.

- Standards for groundwater quality (WAC 173-200) were established to provide for the protection of the environment, human health, and existing and future beneficial uses of groundwater. These standards apply to the Solid Waste Landfill, which is regulated under WAC 173-304.

- Regulations in the Model Toxics Control Act Cleanup (WAC 173-340) may be applicable for sites undergoing remediation. In many cases, these levels are more stringent than maximum contamination levels or drinking water standards.

- Concentration limits may be set in a facility's operating permit or record of decision. 
Table 5.1. Maximum Contaminant Levels and Interim Drinking Water Standards

\begin{tabular}{|c|c|c|c|c|}
\hline Constituent & $\mathrm{MCL}$ or DWS & Agency ${ }^{(a)}$ & & EPA Status \\
\hline Antimony & $0.006 \mathrm{mg} / \mathrm{L}$ & EPA & & Final \\
\hline Arsenic & $0.05 \mathrm{mg} / \mathrm{L}$ & EPA, DOH & & Under review \\
\hline Barium & $2 \mathrm{mg} / \mathrm{L}$ & EPA & & \\
\hline & $1 \mathrm{mg} / \mathrm{L}$ & $\mathrm{DOH}$ & . & Final \\
\hline Cadmium & $5 \mu \mathrm{g} / \mathrm{L}$ & EPA & & Final \\
\hline Carbon tetrachloride & $5 \mu \mathrm{g} / \mathrm{L}$ & EPA, DOH & & Final \\
\hline Chloride & $250 \mathrm{mg} / \mathrm{L}^{(b)}$ & EPA, DOH & & Final \\
\hline Chloroform (THM) & $80 \mu \mathrm{g} / \mathrm{L}$ & EPA & & Proposed \\
\hline & $100 \mu \mathrm{g} / \mathrm{L}$ & $\mathrm{EPA}, \mathrm{DOH}$ & & Final \\
\hline Chromium & $100 \mu \mathrm{g} / \mathrm{L}$ & $\mathrm{EPA}, \mathrm{DOH}$ & & Final \\
\hline cis-1,2-Dichloroethylene & $70 \mathrm{mg} / \mathrm{L}$ & EPA & & Final \\
\hline Copper & $1.0 \mathrm{mg} / \mathrm{L}^{(\mathrm{b})}$ & $E P A, D O H$ & & Final \\
\hline Cyanide & $200 \mathrm{mg} / \mathrm{L}$ & EPA & & Final \\
\hline 1,4-Dichlorobenzene & $75 \mathrm{mg} / \mathrm{L}$ & EPA & & Final \\
\hline Fluoride & $4 \mathrm{mg} / \mathrm{L}$ & EPA, DOH & & \\
\hline & $2 \mathrm{mg} / \mathrm{L}^{(b)}$ & EPA & & Final \\
\hline Iron & $0.3 \mathrm{mg} / \mathrm{L}^{(\mathrm{b})}$ & EPA & & Final \\
\hline Lead & $0.015 \mathrm{mg} / \mathrm{L}^{(\mathrm{d})}$ & EPA & & \\
\hline & $0.05 \mathrm{mg} / \mathrm{L}$ & $\mathrm{DOH}$ & & Final \\
\hline Manganese & $50 \mathrm{mg} / \mathrm{L}^{(\mathrm{b})}$ & $\mathrm{EPA}, \mathrm{DOH}$ & & Final \\
\hline Mercury (inorganic) & $0.002 \mathrm{mg} / \mathrm{L}$ & EPA, DOH & & Final \\
\hline Methylene chloride & $5 \mathrm{mg} / \mathrm{L}$ & EPA & & Final \\
\hline Nickel & $0.1 \mathrm{mg} / \mathrm{L}$ & $\mathrm{EPA}$ & & Final/being remanded \\
\hline Nitrate, as $\mathrm{NO}_{3}$ & $45 \mathrm{mg} / \mathrm{L}$ & $\mathrm{EPA}, \mathrm{DOH}$ & & Final \\
\hline Nitrite, as $\mathrm{NO}_{2}$ & $3.3 \mathrm{mg} / \mathrm{L}$ & $\mathrm{EPA}$ & & Final \\
\hline Pentachlorophenol & $1 \mathrm{mg} / \mathrm{L}$ & $\mathrm{EPA}$ & & Final \\
\hline $\mathrm{pH}$ & 6.5 to $8.5^{(\mathrm{b})}$ & EPA & & Final \\
\hline Selenium & $0.05 \mathrm{mg} / \mathrm{L}$ & EPA & & Final \\
\hline Silver & $0.1 \mathrm{mg} / \mathrm{L}^{(\mathrm{b})}$ & $\mathrm{EPA}, \mathrm{DOH}$ & & Final \\
\hline Sulfate & $500 \mathrm{mg} / \mathrm{L}$ & $\mathrm{EPA}$ & & Proposed \\
\hline & $250 \mathrm{mg} / \mathrm{L}^{(b)}$ & $\mathrm{EPA}$ & & Final \\
\hline Tetrachloroethylene & $5 \mu \mathrm{g} / \mathrm{L}$ & $\mathrm{EPA}, \mathrm{DOH}$ & & Final \\
\hline Thallium & $2 \mu \mathrm{g} / \mathrm{L}$ & EPA & & Final \\
\hline Total dissolved solids & $500 \mathrm{mg} / \mathrm{L}^{(\mathrm{b})}$ & EPA & & Final \\
\hline 1,1,1-Trichloroethane & $0.2 \mathrm{mg} / \mathrm{L}$ & EPA & & Final \\
\hline Trichloroethylene & $5 \mu \mathrm{g} / \mathrm{L}$ & EPA, DOH & & Final \\
\hline Zinc & $5 \mathrm{mg} / \mathrm{L}^{(\mathrm{b})}$ & $\mathrm{EPA}, \mathrm{DOH}$ & & Final \\
\hline Antimony-125 & $300 \mathrm{pCi} / \mathrm{L}^{(e)}$ & $\mathrm{EPA}$ & & Interim \\
\hline Beta particle and photon activity & $4 \mathrm{mrem} / \mathrm{yr}^{(f)}$ & $\mathrm{EPA}, \mathrm{DOH}$ & & Final \\
\hline Carbon-14 & $2,000 \mathrm{pCi} / \mathrm{L}^{(\mathrm{e})}$ & $\mathrm{EPA}$ & & Interim \\
\hline Cesium-137 & $200 \mathrm{pCi} / \mathrm{L}^{(\mathrm{e})}$ & $\mathrm{EPA}$ & & Interim \\
\hline Cobalt -60 & $100 \mathrm{pCi} / \mathrm{L}^{(\mathrm{c})}$ & EPA & & Interim \\
\hline lodine-129 & $1 \mathrm{pCi} / \mathrm{L}^{(\theta)}$ & $\mathrm{EPA}$ & & Interim \\
\hline Ruthenium-106 & $30 \mathrm{pCi} / \mathrm{L}^{(\mathrm{e})}$ & $\mathrm{EPA}$ & & Interim \\
\hline Strontium-90 & $8 \mathrm{pCi} / \mathrm{L}^{(e)}$ & EPA & & Interim \\
\hline Technetium-99 & $900 \mathrm{pCi} / \mathrm{L}^{(e)}$ & EPA & & Interim \\
\hline Total alpha (excluding uranium) & $15 \mathrm{pCi} / \mathrm{L}^{(\mathrm{e})}$ & $\mathrm{EPA}, \mathrm{DOH}$ & & Final \\
\hline Tritium & $20,000 \mathrm{pCi} / \mathrm{L}^{(\mathrm{c})}$ & $\mathrm{EPA}$ & & Interim \\
\hline Uranium & $20 \mu \mathrm{g} / \mathrm{L}$ & $\mathrm{EPA}$ & & Proposed \\
\hline
\end{tabular}

(a) $\mathrm{DOH}=$ Washington State Department of Health at WAC 246-290; EPA = U.S. Environmental Protection Agency at 40 CFR 141, 40 CFR 143, and EPA 822-R-96-001.

(b) Secondary maximum contaminant level.

(c) Standard is for total trihalomethanes (THM).

(d) Action level.

(e) Concentration assumed to yield an annual dose equivalent of $4 \mathrm{mrem} / \mathrm{yr}$.

(f) Beta and gamma radioactivity from anthropogenic radionuclides. Annual average concentration shall not produce an annual dose from anthropogenic radionuclides equivalent to the total body or any internal organ dose $>4 \mathrm{mrem} / \mathrm{yr}$. If two or more radionuclides are present, the sum of their annual dose equivalents shall not exceed 4 mrem/yr. Compliance may be assumed if annual average concentrations of total beta, tritium, and strontium- 90 are $<50,20,000$, and $8 \mathrm{pCi} / \mathrm{L}$, respectively.

DWS $=$ Drinking water standard.

$\mathrm{MCL}=$ Maximum contaminant level. 
Table 5.2. Derived Concentration Guides ${ }^{(\mathrm{a}, \mathrm{b}, \mathrm{c})}$ and 4-mrem Effective Dose Equivalent Concentrations for Drinking Water ${ }^{(d)}$

\begin{tabular}{|c|c|c|}
\hline Radionuclide & $\begin{array}{l}\text { Derived Concentration } \\
\text { Guide, } \mathrm{pCi} / \mathrm{L} \\
\end{array}$ & $\begin{array}{l}\text { 4-mrem Effective Dose } \\
\text { Equivalent, } \mathrm{pCi} / \mathrm{L} \\
\end{array}$ \\
\hline Tritium & $2,000,000$ & 80,000 \\
\hline Carbon-14 & 70,000 & 2,800 \\
\hline Chromium-51 & $1,000,000$ & 40,000 \\
\hline Manganese-54 & 50,000 & 2,000 \\
\hline Cobalt -60 & 5,000 & 200 \\
\hline Zinc-65 & 9,000 & 360 \\
\hline Krypton-85 & NS & NS \\
\hline Strontium-90 & 1,000 & 40 \\
\hline Technetium-99 & 100,000 & 4,000 \\
\hline Ruthenium-103 & 50,000 & 2,000 \\
\hline Ruthenium-106 & 6,000 & 240 \\
\hline Antimony-125 & 60,000 & 2,400 \\
\hline Iodine- 129 & 500 & 20 \\
\hline lodine-131 & 3,000 & 120 \\
\hline Cesium-134 & 2,000 & 80 \\
\hline Cesium-137 & 3,000 & 120 \\
\hline Cerium-144 & 7,000 & 280 \\
\hline Uranium-234 & 500 & 20 \\
\hline Uranium-235 & 600 & 24 \\
\hline Uranium-238 & 600 & 24 \\
\hline Plutonium-238 & 40 & 1.6 \\
\hline Plutonium-239 & 30 & 1.2 \\
\hline Plutonium-240 & 30 & 1.2 \\
\hline Americium-241 & 30 & 1.2 \\
\hline
\end{tabular}

(a) Concentration of a specific radionuclide in water that could be continuously consumed at average annual rates and not exceed an effective dose equivalent of $100 \mathrm{mrem} / \mathrm{yr}$.

(b) Values in this table represent the lowest, most conservative derived concentration guides considered potentially applicable to Hanford Site operations, and may be adjusted upward (larger) if accurate solubility information is available.

(c) From DOE Order 5400.5.

(d) Concentration of a specific radionuclide in water that would produce an effective dose equivalent of $4 \mathrm{mrem} / \mathrm{yr}$ if consumed at average annual rates. NS $=$ No standard. 


\subsection{Vadose Zone Monitoring Methods}

Radioactive and hazardous waste in the soil column from past intentional liquid waste disposals, unplanned leaks, solid waste burial grounds, and underground tanks at the Hanford Site are potential sources of continuing/future groundwater contamination. In recent years vadose zone monitoring has included geophysical logging and soil-vapor monitoring. These methods are described in the following sections.

\subsection{Geophysical Logging}

The objectives of vadose zone borehole monitoring are to document the amount, location, and movement of contamination and moisture in the soil column. The most frequently used borehole monitoring methods at the Hanford Site are gamma-ray and moisture logging. Logging instruments are lowered by an automated hoist, which is controlled by a computer system in the logging truck. The tools are centered in the borehole by a centralizer. The data collection procedures are described in WMNW-CM-004.

Three types of monitoring structures are used for logging: (1) older, vadose zone boreholes and groundwater monitoring wells in and near past-practice sites; (2) new RCRA-compliant groundwater monitoring wells; and (3) single-shell tank farm vadose-zone borehole networks.

\subsubsection{Spectral Gamma-Ray Logging}

Data are acquired with a high-purity germanium (HPGe) detector. Signals from the detector are amplified in the logging tool and transmitted by cable to the computer in the logging truck. The computer controls the logging speeds, which are 2.1 or 2.4 centimeters per minute, depending on the sensitivity of the detector.

Spectral gamma logging requires two calibrations: (1) a depth calibration of the cable and cable hoist system and (2) a calibration of the detector and associated
A geophysical technique known as spectral gamma logging is used to measure certain radionuclides in boreholes in the - unsaturated zone. This technique is used periodically near storage tanks, cribs, and trenches to monitor whether contaminants are moving through the soil.

electronics. Depth calibration of the logging system cable hoist is performed by the equipment manufacturer as part of the system assembly and checkout. A depth recalibration is required after system components are subjected to major repairs or alterations. Calibration of the HPGe logging system is required once each year. Calibration measurements are made in the calibration facilities at the Hanford Site. The calibration standards and their construction are described by Stromswold (1994). The analysis of the calibration data and the resulting calibration factors are described in WHC-SD-EN-TI-292.

A quality assurance/quality control requirement for spectral gamma-ray logging is collection of a repeat log section. The logging procedures dictate that the repeat log interval shall be 3 meters or $10 \%$ of total borehole depth, whichever is smaller. Deviations in the log data between the main $\log$ and repeat log must be within standard statistical limits or the log is rerun.

\subsubsection{Neutron Moisture Logging}

The moisture tool employs a 50-mCi AmericiumBeryllium ( $\mathrm{AmBe}$ ) neutron source and a helium-3 detector. The tool is attached to and controlled by the logging system in the same manner as described for the HPGe logging tool. Emitted neutrons from the $\mathrm{AmBe}$ source scatter on the surrounding nuclei of the formation and borehole casing. The source neutrons 
slow down to thermal energies after a sufficient number of collisions. Hydrogen is the dominant nucleus affecting the neutron slow-down. The thermal neutron detector then measures the intensity of the thermal neutrons and the observed count rates correspond to the moisture content. The moisture tool is operated at a logging speed of 30 centimeters per minute at a data sampling interval of 7.6 centimeters. All the boreholes are logged throughout their lengths unless multiple casing strings are present or if grout seals have been placed around the casing. Computer software converts the gross counts to moisture percent by volume.

Procedures for calibration of the neutron moisture tool are documented in WHC-SD-EN-TI-304 and WHC-SD-EN-TI-306. Calibration of the logging system cable and cable hoist system was as described above.

A quality assurance/quality control requirement for neutron moisture logging is collection of a repeat log section. The logging procedures dictate that the repeat log interval shall be 3 meters or $10 \%$ of total borehole depth, whichever is smaller.

\subsubsection{Time Lapse Comparison of Gamma Logs}

Spectral gamma and gross gamma logs from different years are sometimes compared to detect migration of radionuclides in the subsurface. Several adjustments are performed to the data in order to make quantitative comparison of the radionuclide concentrations from the separate spectral gamma data sets. First, the earlier log results are decay corrected (according to the specific isotope) to the date of the more recent log. Second, the casing correction methods are updated if necessary, to ensure both logs have the same correction factors.

Historical gross gamma logs can be compared to the gross gamma logs collected by the spectral instrument. The older logs were obtained with instruments that were operated only in the gross gamma mode. The detectors were typically scintallator crystal detectors, which have poor energy resolution compared to the high purity germanium detectors. Differences in the detector composition and size result in different efficiencies for the gross gamma response. A given concentration of cesium-137, for example, will yield different observed count rates for the two gross gamma results. The comparison of older gross gamma logs with recent logs is done qualitatively by plotting each log on a different scale.

Decay correction should also be applied to the older gross gamma data in order to compare with the recent data. However, this would require the complex adjustment of the older log on an isotope by isotope basis. Therefore, no decay corrections were attempted for any comparisons of older gross gamma logs with recent gross gamma logs.

The older gross gamma log results were only available on chart paper. Copies of the charts were digitized to facilitate the graphical comparison. Since the quantitative comparison of older gross gamma logs with the recent gross gamma response is not possible without extensive calibration efforts, the comparison can only yield indications and not rigorous conclusions. However, changes in the depth distribution of contaminants can sometimes be discounted using the gross gamma time lapse comparison performed.

\subsection{Soil-Vapor Monitoring}

Soil-vapor extraction is being used to remove the carbon tetrachloride from the vadose zone as part of the 200 West Area expedited response action being conducted by Bechtel Hanford, Inc. To track the effectiveness of the remediation effort, measurements of soil-vapor concentrations of chlorinated hydrocarbons are made at the inlet to the soil-vapor extraction system, at individual on-line extraction wells, and at individual off-line wells and probes throughout the soil-vapor extraction sites. 


\subsubsection{Methods}

Contaminant concentrations at the soil-vapor extraction inlets and vent stacks and at individual wells and probes have been monitored using a Type $1302^{\mathrm{TM}}$ infrared photoacoustic spectrometer (Brüel and Kjaer, Naerum, Denmark). The Brüel and Kjaer sensors are calibrated annually by the manufacturer and are periodically checked with calibrated standards in the field. The detection limit for carbon tetrachloride is 1 part per million by volume $\left(\mathrm{ppm}_{\mathrm{v}}\right)$.

Soil vapor is being pumped from the unsaturated sediment beneath the 200 West Area to remove gaseous carbon tetrachloride. Soil vapor is monitored to assess progress on this cleanup system.

Measurements made at the inlet to the extraction system represent the combined soil-vapor concentrations from all on-line wells connected to the system. A programmable logic controller samples the incoming concentrations at the inlet every two hours; the system technician uses these data to establish daily records of representative concentrations.

To monitor concentrations at individual on-line extraction wells, a sampling apparatus is placed in-line at the wellhead to collect a soil-vapor sample in a Tedlar $^{\mathrm{TM}}$.bag (E.I. du Pont de Nemours \& Company, Wilmington, Delaware). The sample is analyzed using a Brüel and Kjaer sensor housed in a trailer near the extraction site. Concentrations are typically monitored monthly at individual on-line extraction wells. One snapshot sample is collected at each on-line extraction well.

Soil-vapor monitoring at off-line wells and probes is conducted using the sampling methods developed for the rebound study conducted in fiscal year 1997 (BHI01105). A low-flow ( 0.8 liters per minute) pump is used to draw soil-vapor samples from wells and probes into a 1-liter Tedlar ${ }^{\mathrm{TM}}$ bag for analysis using the field
Brüel and Kjaer sensor. Two purge volumes are drawn before the sample is collected. For most of the wells in which the sampling pump is used, a tube is lowered to the target depth, where the casing is perforated (i.e., open to the sediment and its pores) to minimize the volume of air to be purged. A metal filter, which is attached to the end of the tube, also serves as a weight. Each sampling tube remains in the well for the duration of the monitoring period. Each well equipped with a sampling tube remains sealed at the surface throughout the monitoring period. As a test at a limited number of wells, the sampling pump was used to collect a sample at the wellhead without use of a sampling tube extended to the perforated interval. These wells were purged for either 3 or 10 minutes using the sampling pump. The wells remained sealed, and the sample pump was used to collect samples in 1-liter Tedlar ${ }^{\mathrm{TM}}$ bags for analysis using the Brüel and Kjaer sensor.

Soil-vapor samples are collected from $\sim 25$ off-line wells and probes once per month. Soil-vapor samples are analyzed primarily to monitor for carbon tetrachloride; however, the samples collected from off-line wells and probes were also analyzed for chloroform, methylene chloride, methyl ethyl ketone, and water vapor.

\subsubsection{Networks}

There are 46 drilled wells available for on-line extraction or monitoring (BHI-00720, Rev. 2) (Figure 6.1). Thirteen of these wells were drilled during 1992 and 1993 and were completed as vapor-extraction wells with stainless steel casing and screens; one well was drilled at a 45-degree incline. Thirty-three wells, drilled between 1954 and 1978 and completed with carbon steel casing, were adapted for vapor extraction by perforating the well casing using mechanical or jet perforators. Of the 46 wells, 17 have two screened or perforated intervals isolated by downhole packers. The soil-vapor extraction system extracts simultaneously from multiple wells open above and/or below the Plio-Pleistocene unit. The mix of on-line wells is adjusted periodically to optimize contaminant removal. 
There are 125 subsurface monitoring probes more than 2 meters deep. A cone penetrometer was used to install 11 monitoring wells and 104 subsurface monitoring probes at 33 locations. Up to five monitoring probes were installed per location at various depths. The deepest monitoring probe installed at the vapor extraction sites is 36 meters below ground surface. Ten stainless steel tubes were strapped to the outside of the casing of 4 of the 13 wells during installation to enable monitoring above and below the screened intervals.
There are up to 73 shallow soil-vapor probes at depths ranging from 1.2 to 1.8 meters (Figure 6.2). The network was installed between 1991 and 1995 . Some of the probes have since been destroyed, primarily as a result of other near-surface construction activities or prolonged exposure to weather conditions. 


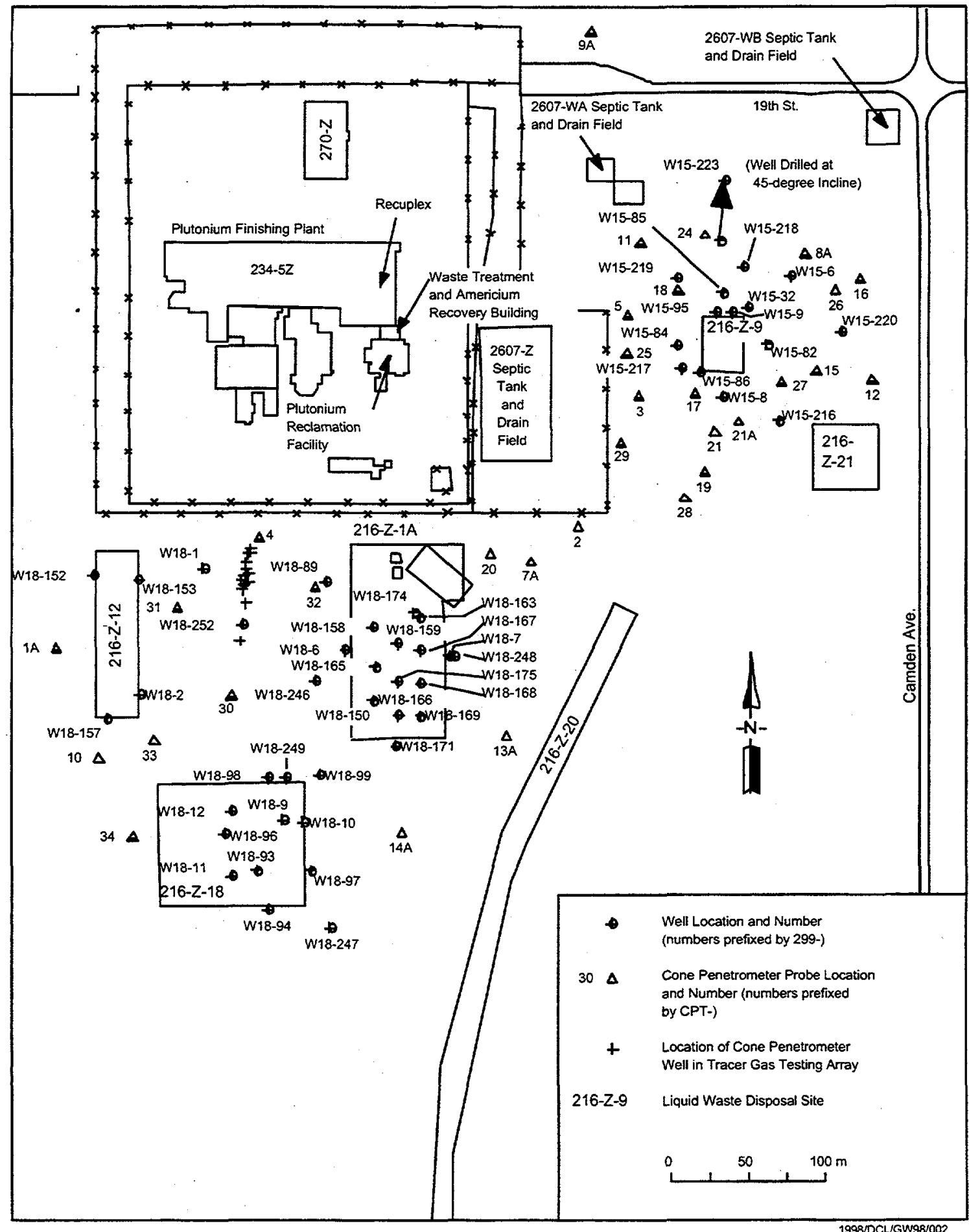

Figure 6.1. Location of Wells and Deep Soil-Vapor Monitoring Probes at the Carbon Tetrachloride Vapor Extraction Site 


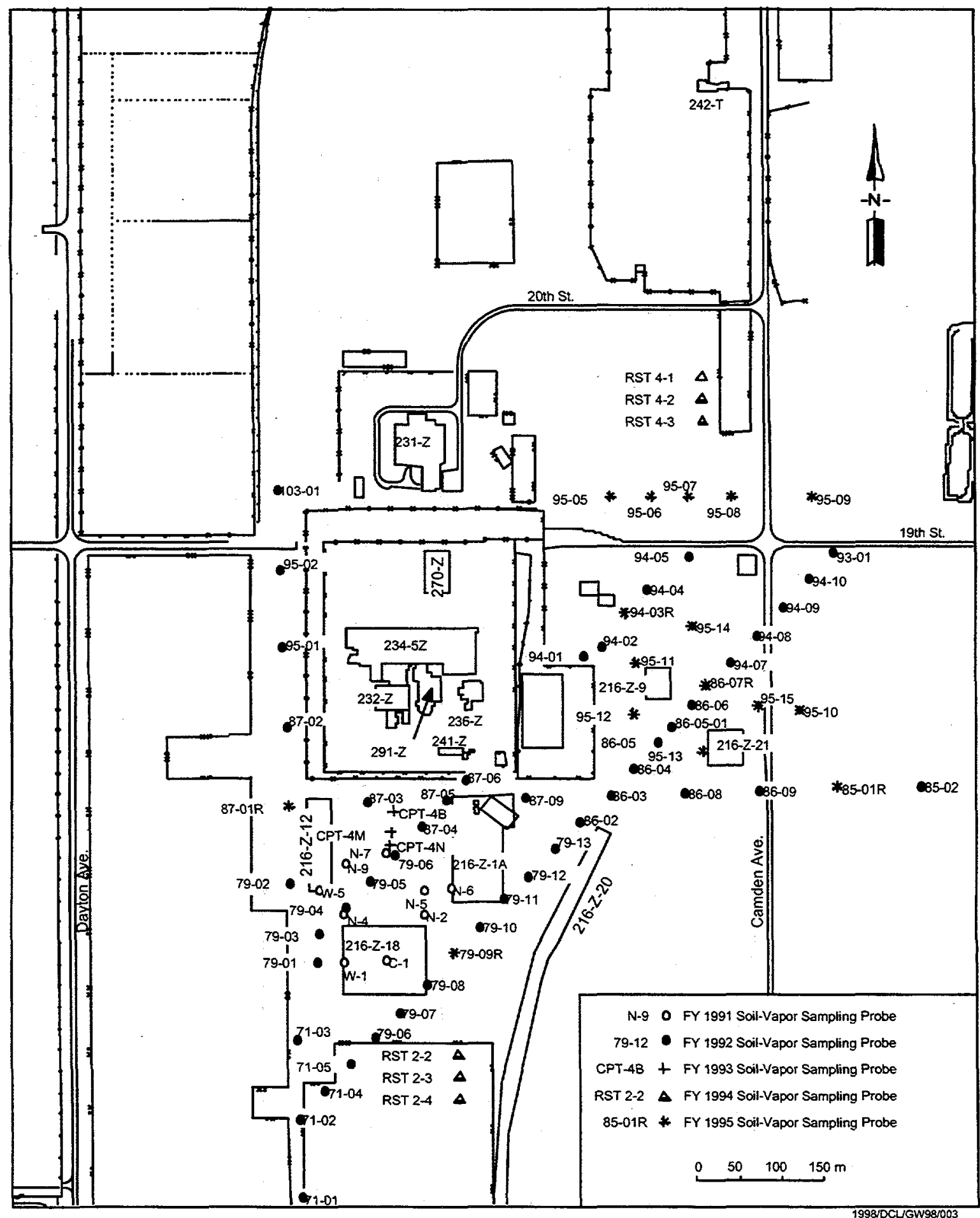

Figure 6.2. Location Map of Shallow Soil-Vapor Monitoring Probes at the Carbon Tetrachloride Vapor Extraction Site 


\subsection{Statistical Methods}

Data gathered in support of groundwater monitoring at the Hanford Site are used to evaluate the changes noted in groundwater quality from baseline conditions of the various facilities. The methods used for the statistical evaluations are briefly described in this section. The facilities included in this evaluation are

- RCRA liquid and solid waste treatment, storage, and/or disposal units

- Solid Waste Landfill

- some liquid effluent receiving facilities where statistical comparisons of groundwater samples were specified in the groundwater monitoring plans.

The RCRA units with a potential to contaminate groundwater require monitoring as prescribed in 40 CFR 265, WAC 173-303-400 (interim status), and 40 CFR 264 Subpart F and WAC 173-303-645 (final status). Groundwater monitoring activities at most of the RCRA units are currently governed by interim status regulations, except for the $183-\mathrm{H}$ solar evaporation basins and the $316-5$ process trenches, which were subject to corrective-action programs in accordance with final status regulations. The Solid Waste Landfill, though not a RCRA hazardous waste site, is statistically evaluated according to requirements of WAC 173-304. A permit application for the Solid Waste Landfill was prepared (DOE/RL-90-38, Rev. 0).

Statistical comparisons of groundwater data provide an objective measure of whether waste sites are affecting groundwater quality. Methods used on the Hanford Site are based on those prescribed by environmental regulators such as EPA.
Operations at the 200 Areas Treated Effluent Disposal Facility and the State-Approved Land Disposal Site began during 1995. Another facility, the 4608 B/C ponds (also called the 400 Area process ponds), consists of unlined infiltration ponds that receive wastewater from the 400 Area facilities. These sites are regulated by WAC 173-216. Because these are discharge permit disposal facilities, they require effluent and groundwater monitoring. Upgradient and downgradient comparisons for constituents of concern were performed at these sites in accordance with groundwater monitoring plans.

\subsection{RCRA Interim Status Facilities}

The primary objectives of RCRA groundwater monitoring are to comply with regulatory requirements and agreements; to assess potential impact on groundwater quality; and to identify near-term corrective measures, if feasible, for the protection of human health and the environment. In accordance with 40 CFR 265 Subpart $F$ (which was incorporated, by reference, into WAC 173-303-400), RCRA projects are monitored according to one of three levels of effort:

- background monitoring

- indicator evaluation

- groundwater quality assessment.

All of the RCRA facilities at the Hanford Site have completed their initial background monitoring programs. A general description of the applicable statistical methods that are appropriate for these interim status facilities is provided in this section.

The statistical method used to summarize background data is the averaged replicate t-test method as described in Appendix B of OSWER-9950.1 and Chou 
(1991). The averaged replicate $t$-test method for each contamination indicator parameter during each evaluation period is calculated as

$$
\mathbf{t}=\left(\overline{\mathbf{x}}_{\mathrm{i}}-\overline{\mathbf{x}}_{\mathrm{b}}\right) / \mathrm{S}_{\mathrm{b}} * \sqrt{1+1 / \mathrm{n}_{\mathrm{b}}}
$$

where $t=$ test statistic

$x_{i}=$ average of replicates from the $i^{\text {th }}$ monitoring well

$\mathrm{x}_{\mathrm{b}}=$ background average

$\mathrm{S}_{\mathrm{b}}=$ background standard deviation

$\mathbf{n}_{\mathrm{b}}=$ number of background replicate averages .

The guiding documentation (OSWER-9950.1) states that a test statistic larger than the Bonferroni critical value, $t_{c}$, (i.e., $t>t_{c}$ ) indicates a statistically significant increase (or decrease, for $\mathrm{pH}$ ) compared to the background data. This increase or decrease would indicate that contamination may have occurred. These Bonferroni critical values depend on the overall falsepositive rate required for each sampling period (i.e., $1 \%$ for interim status), the total number of wells in the monitoring network, and the number of degrees of freedom $\left(n_{b}-1\right)$ associated with the background standard deviation. Because of the nature of the test statistic in Equation (7.1), sampling results to be compared to background do not contribute to the estimate of the variance, $\mathrm{S}_{b}{ }^{2}$. The test can be reformulated, without prior knowledge of the results of the sample to be compared to background, in such a way that a critical mean, $\mathrm{CM}$, can be obtained

$$
\begin{aligned}
& \mathrm{CM}=\bar{x}_{\mathrm{b}}+\mathrm{t}_{\mathrm{c}} * S_{\mathrm{b}} * \sqrt{\left(1+1 / \mathrm{n}_{\mathrm{b}}\right)} \quad \text { (one tailed) } \\
& \mathrm{CM}=\bar{x}_{\mathrm{b}} \pm \mathrm{t}_{\mathrm{c}} * S_{\mathrm{b}} * \sqrt{\left(1+1 / \mathrm{n}_{\mathrm{b}}\right)} \quad \text { (two tailed) }
\end{aligned}
$$

For $\mathrm{pH}$, a two-tailed $\mathrm{CM}$ (or critical range) is calculated and a one-tailed CM is calculated for specific conductance, total organic carbon, and total organic halides. The $\mathrm{CM}$ (or range for $\mathrm{pH}$ ) is the value above which (or above/below in the case of $\mathrm{pH}$ ) a compared value is determined to be statistically different from background.
In the past, the lack of estimates of background variability for total organic carbon and/or total organic halides and concerns over laboratory's procedure over total organic halides precluded the determination of critical means for various RCRA facilities. And, a limit of quantitation was used as the surrogate background value for upgradient/downgradient comparisons. During fiscal year 1999, method detection limits for total organic carbon and total organic halides were improved and thus, making the determination of critical means possible. The calculated critical means were used in the statistical evaluations unless the calculated critical means were not quantifiable. In this case, a limit of quantitation was used as the threshold value for the regulatory decision in determining whether a RCRA facility has impacted the groundwater quality beneath the facility. The limit of quantitation and limit of detection are determined quarterly and the most recent updated values are used in statistical evaluations.

Finally, if the calculated critical ranges for $\mathrm{pH}$ were too large to be meaningful because of the requirement to use four quarters of data to establish background (e.g., 216-A-29 Ditch), the upgradient/downgradient comparison value would be revised to the critical range by using more data. The expansion of the background dataset to include more than 1 year's data provides a better estimate of background mean and background standard deviation. More important, it increases the number of degrees of freedom associated with the background standard deviation. Other things being equal, a smaller $t_{c}$ value and a narrower critical range for $\mathrm{pH}$ would result. This approach is preferred because it complies with both the requirements and the spirit of the regulations.

\subsection{RCRA Final Status Facilities}

Three levels of groundwater monitoring programs are required by the final-status regulations ( 40 CFR 264 Subpart F and WAC 173-303-645): detection monitoring, compliance monitoring, and corrective action. The 183-H solar evaporation basins and the 316-5 
process trenches are monitored in accordance with the RCRA final status requirements. Additionally, four permitted treatment, storage, and disposal facilities (i.e., 1301-N Liquid Waste Disposal Facility, 1324-N/NA Liquid Waste Disposal Facilities, 1325-N Liquid Waste Disposal Facility and Liquid Effluent Retention Facility), as of September 30, 1999, are also regulated under final status requirements. Groundwater monitoring, however, is regulated under interim status requirements in accordance with guidance provided by Washington State Department of Ecology.

Evaluation of groundwater monitoring data under interim status involves use of a t-test to compare mean concentrations of the four contamination indicator parameters between upgradient and downgradient wells on the four replicate measurements during each sampling event. This required method is flawed (see Davis 1994 and Cameron 1996) because

- the required pooling of background data is not valid when spatial, temporal, and sampling variability constitute a significant portion of the total variability

- a static background is assumed because one initial set of background samples is collected and statistically compared to downgradient data collected during later monitoring

- the background data pool does not incorporate any component of spatial variability when only one upgradient well is used

- the four indicator parameter selected do not serve well as early warning indicators of incipient contamination of groundwater by leachate from the facility.

In final status monitoring, flexibility is allowed in selecting statistical methods as well as constituents used for statistical comparison. Appropriate statistical methods include analysis of variance, tolerance intervals, prediction intervals, control charts, test of proportions, or other statistical methods approved by the regulator. The important factors to consider when selecting appropriate statistical methods are the distribution(s) of monitoring parameters; the nature of the data; and the proportions of non-detections, seasonal, temporal, and spatial variations. The statistical evaluation procedures chosen for final-status facilities will be based on guidance given in PB89-151047, EPA/530-R-93-003, and American Society for Testing and Materials (1996). Specific statistical methods are to be addressed in the unit-specific permit applications and/or in the groundwater monitoring plans.

\subsubsection{Detection-Level Monitoring}

In a detection-level groundwater monitoring program, the objective is to detect a potential impact from a regulated unit by testing for statistically significant changes in geochemistry in a downgradient monitoring well relative to baseline levels. These baseline levels could be obtained from upgradient (or background) wells, and the comparisons are referred to as interwell (or between-well) comparisons. Alternatively, if baseline values are obtained from historical measurements from that same well, the comparisons are referred to as intrawell (or within-well) comparisons. Groundwater parameter data (e.g., $\mathrm{pH}$, specific conductance, total organic carbon, total organic halides, heavy metals, waste constituents, reaction products) from downgradient, compliance-point wells will be compared semiannually with baseline data to determine whether there is a statistically significant increase (or decrease for $\mathrm{pH}$ ) over baseline concentrations. Final status, detection-level, groundwater monitoring plans for the Liquid Effluent Retention Facility and Low-Level Burial Grounds were proposed and presented to the Washington State Department of Ecology. However, a decision was made to not incorporate the low-level burial grounds into the permit until 2002 . Therefore, these sites continue to be monitored in accordance with interim status requirements. Although the Liquid Effluent Retention Facility was included in the Hanford Site RCRA Permit, groundwater monitoring will continue in interim status until a permanent method of monitoring the facility is designed and implemented to fulfill final status monitoring requirements. 


\subsubsection{Compliance-Level Monitoring}

A compliance-level, groundwater monitoring program will be established for a RCRA unit if groundwater sampling during detection-level monitoring reveals statistically significant evidence of contamination for constituents of concern at any monitoring well at the compliance point. In compliance-level monitoring, the objective is to determine whether specified concentration limits (e.g., groundwater protection standards) have been exceeded. This is accomplished by comparing the concentration of a constituent of concern to a concentration limit, such as a riskbased maximum concentration limit; alternative concentration limit; area or natural background; or applicable, relevant, and appropriate requirements. These concentration limits would be applied during compliance monitoring to determine whether corrective action might be necessary.

Maximum concentration limits will be identified for each groundwater monitoring constituent of concern. Alternative concentration limits will be proposed after considering the observed concentrations of chemical constituents in the groundwater that might have originated from the regulated unit in question. The area background, natural background, and other standards that are applicable, relevant, and appropriate will be evaluated when proposing an alternative concentration limit. The parameters monitored, the concentration limits, and the statistical methods were specified in the unit-specific groundwater-monitoring plan (e.g., WHC-SD-EN-AP-180) and approved by Ecology.

Results of groundwater monitoring indicate that the $316-5$ process trenches exceed concentration limits for trichloroethylene, cis-1,2-dichloroethylene, and uranium in some of the downgradient compliance wells. The Washington State Department of Ecology was notified and the site RCRA permit was revised, putting the $316-5$ process trenches into corrective action. However, the compliance-level plan remains in effect pending approval of the corrective action monitoring plan.

\subsubsection{Corrective Action}

A corrective action program is initiated if a concentration limit at the point of compliance is exceeded. Exceedance is defined as statistically significant evidence of increased contamination [see WAC 173-303. 645 (2)(a)(ii)]. Details for the corrective action program will be specified in the unit-specific permit application. In addition, a groundwater monitoring plan, which will be used to assess the effectiveness of the corrective-action measures, will be submitted for approval. That monitoring plan may be similar in scope to the compliance-level, groundwater monitoring program and may include all relevant information pertaining to the location and description of monitoring wells, monitoring network, well construction and development, sampling and analysis plans, statistical methods, and quality assurance and quality control procedures. The 183-H solar evaporation basins are monitored under a corrective action plan.

\subsection{Solid Waste Landfill}

Groundwater monitoring activities at the Solid Waste Landfill are regulated in accordance with WAC 173-304-490, requiring no replicate analyses. Thus, the tolerance interval approach, suitable for individual sample comparisons, was used for performing the required comparisons between upgradient and downgradient wells for determining whether a significant change over background occurred for constituents specified in WAC 173-304-490. The statistical evaluations are described as follows.

\subsubsection{Calculating Background Summary Statistics}

Summary statistics were calculated using background samples for the site (Table B-11 in DOE/ RL-91-03). The results were presented in Table B.1 of PNNL-11793. Some of the background data are below the contractual detection limits required of the contracting laboratory or below the contractually required quantitation limit. In cases where measured values are available (e.g., most of the total organic 
carbon values), they were used in calculating the summary statistics. In cases where the proportion of nondetections is between $15 \%$ and $50 \%$, less-than values were replaced by half of the method detection limits and/or contractually required quantitation limits, and the usual calculations were performed (e.g., filtered iron). In cases where the proportion of non-detections is greater than $50 \%$, summary statistics are not calculated (e.g., ammonium, chemical oxygen demand, coliform, filtered manganese, filtered zinc, nitrite).

\subsubsection{Testing Assumption of Normality of Data}

The tolerance interval defines a concentration range (from background or upgradient well data) that contains at least a specified proportion (coverage) of the population with a specified probability (confidence level). There are two types of tolerance intervals: parametric and non-parametric. Parametric toleranceinterval techniques are sensitive to the assumption that the data are drawn from a normal population. The statistical tests used to evaluate whether the data follow a specified distribution are called goodness-offit tests. The Lilliefors test is used to evaluate the fit of a hypothesized normal or lognormal distribution. STATGRAPHICS ${ }^{\mathrm{TM}}$, Version 6.0 (Statistical Graphics Corporation, Rockville, Maryland) was used to calculate the Lilliefors test statistics. Test procedures are described by Conover (1980). If the data are not normal, the Lilliefors test was applied to the natural logarithm of the data to see if the transformed data are approximately normal. This is equivalent to testing the hypothesis that the concentration measurements follow a lognormal distribution. If the proportion of non-detections is greater than $15 \%$, a goodness-of-fit test is not performed and a non-parametric tolerance interval will be calculated to the extent possible. Results of the Lilliefors tests are presented in groundwater annual reports.

\subsubsection{Establishing Background Levels}

Tolerance intervals are constructed from the data on upgradient wells. Both the upper and lower bounds of the interval (two sided) were calculated for field $\mathrm{pH}$. For other constituents of concern, only the upper bounds of the intervals (one sided) were calculated.

If a normal (or a lognormal) distribution is a reasonable approximation of the background concentrations, a parametric tolerance interval, $\mathrm{TI}$, of the following form is calculated

$$
\mathrm{TI}=\overline{\mathrm{x}}_{\mathrm{b}} \pm \mathrm{k}^{*} \mathrm{~S}_{\mathrm{b}} \text { (two sided) }
$$

or

$$
\mathrm{TI}=\overline{\mathrm{x}}_{\mathrm{b}}+\mathrm{k}^{*} \mathrm{~S}_{\mathrm{b}} \text { (one sided) }
$$

where $\mathrm{k}=$ a normal tolerance factor, which depends on the number of background samples $(n)$, coverage (P\%), and confidence level $(\mathrm{Y})$. A coverage of $95 \%$ and a confidence level of $95 \%$ are recommended (PB89-151047). With $\mathrm{n}=16, \mathrm{P}=95 \%$, and $\mathrm{Y}=95 \%$, $\mathrm{k}$ is 2.523 ( $\mathrm{k}$ is 2.566 if $\mathrm{n}=15$ ) for a one-sided normal tolerance interval (Natrella 1966).

If background concentrations do not follow a normal or lognormal distribution, a non-parametric tolerance interval can be constructed (Conover 1980). A two-sided non-parametric tolerance interval is the range of the observed data. An upper, one-sided, nonparametric tolerance limit is the largest observation. The number of background samples determines the coverage $(\mathrm{P} \%)$ and the confidence level $(\mathrm{Y})$ associated with that proportion. For a one-sided non-parametric tolerance interval with $95 \%$ coverage ( $\mathrm{P}=95 \%$ ), and with $95 \%$ probability $(\mathrm{Y}=95 \%), 59$ background samples are needed (Conover 1980). With only 15 background samples (filtered iron, filtered zinc, and nitrate), the coverage is $85 \%$ and the confidence level is $90 \%$ (i.e., the upper one-sided tolerance limit defined by the largest background concentration contains at least $85 \%$ of the background population with $90 \%$ confidence). More background samples are needed if a larger coverage and/or a larger confidence level are desired.

In cases where all of the background values are below the contractually established detection limits or where the proportion of non-detections is greater than $15 \%$, a limit of quantitation was used (e.g., total organic carbon). In cases where a limit of quantitation is not 
available (e.g., chemical oxygen demand, coliform), the contractually required quantitation limits were used as the background threshold values. The resulting tolerance limits, limits of quantitation, and background threshold values are also presented in groundwater annual reports.

\subsubsection{Comparisons with Background Levels}

Once the background threshold values are established, data from point-of-compliance wells were compared individually with these background concentration levels. If the background levels are exceeded, it is interpreted as providing evidence of statistically significant contamination.

\subsection{Liquid Effluent Receiving Facilities}

Operation of the 200 Areas Treated Effluent Disposal Facility and the State-Approved Land Disposal Site began during 1995. These facilities are regulated by WAC 173-216; both require effluent and groundwater monitoring. Another facility, the 400 Area process ponds, is designated also as a WAC 173-216 discharge permit site. The permit was issued on August 1, 1996 and modified on February 10, 1998. The principal groundwater quality regulations (WAC 173-200) emphasize the non-degradation of current groundwater quality. These regulations require "Establishment of an enforcement limit as near the natural ground water quality as practical," and establishment of the point of compliance in the groundwater "...as near the source as technically, hydrogeologically, and geographically feasible."

\subsubsection{Preoperational Monitoring}

Groundwater quality data from the preoperational phases of the 200 Areas Treated Effluent Disposal Facility and the State-Approved Land Disposal Site were used to establish the background (baseline) values for the potential constituents of concern. In essence, background values were calculated using the parametric tolerance-interval approach discussed above because background water quality is statistically defined as the $95 \%$ upper tolerance interval with a $95 \%$ confidence (Ecology 1996b, p. 65). The baseline values were provided to the regulator to allow the determination of enforcement limits (specified in the permit) for specific constituents in groundwater.

\subsubsection{Operational Monitoring}

The objectives of collecting and evaluating the groundwater quality data from operational monitoring are (1) to determine if groundwater quality has changed from the baseline, preoperational conditions; (2) to evaluate the impact, if any, that operation of the facility has on the quality of groundwater in the uppermost aquifer; and (3) to demonstrate compliance with the groundwater enforcement limits set forth in the permit.

Statistical approaches used for preoperational and operational monitoring were described in detail in the groundwater-monitoring plans for the 200 Areas Treated Effluent Disposal Facility (WHC-SD-EN. WP-012, Rev. 1) and State-Approved Land Disposal Site (WHC-SD-C018H-PLN-004, Rev, 1). 


\subsection{Analytical Methods}

The methods for analysis of chemical constituents in groundwater at the Hanford Site conforms to the U.S. Environmental Protection Agency's (EPA's) Test Methods for Evaluating Solid Wastes: Physicall Chemical Methods, 3rd Ed. (SW-846); Methods for Chemical Analysis of Water and Wastes (EPA-600/4-79-020) or other EPA methods; and the Annual Book of ASTM Standards (American Society for Testing and Materials 1986). The methods used for analysis of radiochemical constituents were developed by the analyzing laboratory and are recognized as acceptable within the technical radiochemical industry. The methods used to obtain routine data results are presented in Table 8.1 and are organized into several categories: general chemicals, ammonia and anions, volatile organic compounds, semivolatile organic compounds, metals, and radionuclides. Brief descriptions of the methods for each test ordered are given in the following sections. Some tests are performed by slightly different methods, depending on the laboratory. Those tests performed in the field are noted in the applicable sections.

Groundwater samples are analyzed using standard methods from EPA and ASTM.

\subsection{General Chemical Analyses}

\subsubsection{Alkalinity}

Method 310.1 (EPA-600/4-79-020) is used to determine alkalinity. The samples are titrated electrometrically with hydrochloric acid or sulfuric acid to an end point of $\mathrm{pH} 4.5$.

\subsubsection{Chemical Oxygen Demand}

Method 410.4 (EPA-600/4-79-020) is used to determine chemical oxygen demand. Organic and oxidizable inorganic substances in the sample are oxidized by potassium dichromate in $50 \%$ sulfuric acid solution at reflux temperature. Silver sulfate is used as a catalyst, and mercuric sulfate is added to remove chloride interference. Intensity is measured spectrophotometrically at 600 nanometers.

In the field, measurements for dissolved oxygen are based on the membrane electrode Method 360.1 (EPA-600/4-79-020).

\subsubsection{Coliform}

Method 9131 (SW-846) is used to determine coliform by the tube fermentation technique. This method consists of a three-stage procedure in which the results are statistically expressed in terms of the most probable number. The three stages are used to determine the probability of coliform growth based on gas production and culture growth.

\subsubsection{Oil and Grease}

Methods 413.1 (EPA-600/4-79-020) and 9070 (SW-846) are used to determine oil and grease in groundwater samples. In this method, the sample is acidified to a low $\mathrm{pH}$ (less than 2) and serially extracted with fluorocarbon-113 in a separatory funnel. The solvent is evaporated from the extract and the residue weighed. The definition of oil and grease is based on the procedure used. The nature of the oil and/or grease and the presence of extractable non-oily matter influences the material measured and interpretation of results. Oil and grease are measures of biodegradable animal greases and vegetable oils along with the relative non-biodegradable mineral oils.

\subsection{5 $\mathrm{pH}$}

$\mathrm{pH}$ is determined by potentiometric measurement using Method 150.1 (EPA-600/4-79-020) in the lab, 
by Method 9040 (SW-846), or company-specific procedures based on EPA methodology and instrument manuals.

\subsubsection{Specific Conductance}

Method 120.1 (EPA-600/4-79-020) or Method 9050 (SW-846) is used to determine the specific conductance of a sample. The conductance is measured by use of a self-contained conductivity meter, Wheatstone bridge-type, or equivalent.

In the field, specific conductance is measured using company-specific procedures based on Method 9050 (SW-846).

\subsubsection{Temperature}

In the field, the temperature of samples is based on company-specific and instrument manual methodology using electronic digital thermometers.

\subsubsection{Total Carbon}

Total carbon measurements are based on instrument manufacturer parameters and Method 415.1 (EPA-600/4-79-020). Carbon in a sample is converted to carbon dioxide by catalytic combustion or wet chemical oxidation. The carbon dioxide formed is measured directly by an infrared detector or converted to methane and measured by a flame ionization detector. The amount of carbon dioxide or methane is directly proportional to the concentration of carbonaceous material in the sample.

\subsubsection{Total Dissolved Solids}

Method 160.1 (EPA-600/4-79-020) is used to determine total dissolved solids. The samples are dried to $180^{\circ} \mathrm{C}$, and the total dissolved solids content determined by the gravimetric technique.

\subsubsection{Total Organic Carbon}

Method 9060 (SW-846) or Method 415.1 (EPA$600 / 4-79-020$ ) is used to determine total organic carbon.
These methods use a carbonaceous analyzer to convert the organic carbon in the sample to carbon dioxide by either catalytic combustion or wet chemical oxidation. The carbon dioxide is then directly measured by an infrared detector or converted to methane and measured by a flame ionization detector. The amount of carbon dioxide or methane measured is directly proportional to the concentration of carbonaceous material in the sample.

\subsubsection{Total Organic Halides}

Method 9020 (SW-846) is used to determine total organic halides. The samples are passed through an activated carbon column. The column is washed to remove any trapped inorganic halides. The sample is then combusted to convert the adsorbed organohalides to hydrogen halide, which is trapped and titrated electrolytically using a microcoulometric detector.

\subsubsection{Total Petroleum Hydrocarbons}

Four methods are used to determine total petroleum hydrocarbons, the first of which is Method 418.1 (EPA-600/4-79-020). This method determines the mineral oils by acidifying the sample to $\mathrm{pH}$ less than 2 and serially extracting with fluorocarbon- 113 in a separatory funnel. Interferences are removed with silica gel absorbent. Infrared analysis of the extract is performed by direct comparison with standards.

Gasoline range total petroleum hydrocarbons are determined using the method in Washington State Department of Ecology (1992), which adapted Methods 5030 and/or 8020 (SW-846) to perform the analysis. The method involves purging an aliquot of sample via a purge-and-trap concentrator and analyzing the purged components using a gas chromatograph equipped with a flame ionization detector. The other method used to determine gasoline range total petroleum hydrocarbons is Method 8015 (SW-846). In this method, the sample is introduced into the gas chromatograph equipped with a flame ionization detector via a purge-and-trap concentrator, automated headspace technique, vacuum distillation, or by another appropriate technique. 
Diesel range total petroleum hydrocarbons are determined using the method in Washington State Department of Ecology (1992), which adapted Methods 3510 and 8000 (SW-846). The method involves extracting the samples with methylene chloride and injecting a portion of the extract into a gas chromatograph equipped with a flame ionization detector. Quantitation is accomplished by integrating to baseline, as a group, the area of components between dodecane through tetracosane.

\subsubsection{Turbidity}

In the field, turbidity values are given as nephelometric measurements based on Method 180.1 (EPA600/4-79-020) or Standard Method 214A (American Public Health Association 1985).

\subsection{Ammonia, Anions, Cyanide, and Sulfide}

\subsubsection{Ammonia}

Ammonia is determined by one of the methods listed below.

A colorimeter is used to determine ammonia by Method 350.1 (EPA-600/4-79-020). The method uses alkaline phenol and hypochlorite to react with ammonia to form indenophenol blue in an amount proportional to the ammonia concentration. The blue color is intensified with sodium nitroprusside. The concentration is measured using a calibrated colorimeter.

Poteniometric determination of ammonia by ionselective ammonia electrode is performed by Method 350.3 (EPA-600/4-79-020).

Using Method 300.7 (EPA-600/4-86-024), a small volume of sample is introduced into an ion chromatograph. The cations of interest are separated and measured, using a system comprised of a guard column, separator column, suppressor device, and conductivity detector. The analysis yields accurate quantitative results for ammonium, calcium, lithium, magnesium, potassium, and sodium.

\subsubsection{Anions}

Method 300.0 or 353.2 (EPA-600/R-93-100) is used to determine nitrate, nitrite, bromide, chloride, fluoride, phosphate, and sulfate. The samples are introduced into an ion chromatograph, where the anions of interest are separated and measured with a conductivity detector. The specific method for the detection of individual anions used in some instances is given below.

Method 353.1 (EPA-600/4-79-020) is used to determine total nitrate plus nitrite. This method is a colorimetric method that first reduced the nitrate to nitrite with either hydrazine or cadmium. Total nitrite is determined colorimetrically by using sulfanilamide and N-(1-naphthyl)-ethylenediamine dihydrochloride to form a highly colored azo dye. The results were expressed as nitrogen in nitrate plus nitrite.

\subsubsection{Cyanide}

Method 9012 (SW-846) or Method 335.3 (EPA600/4-79-020) is used to determine cyanide. The samples are acidified, converting any cyanide to hydrocyanic acid. The samples are then distilled, and the hydrocyanic acid trapped in an absorber scrubber of sodium hydroxide solution. The cyanide ion is converted to cyanogen chloride with Chloramine- $T$, and color formation achieved through the addition of pyridine barbituric acid. The cyanide concentration is then determined by volumetric titration, colorimetry, or automated ultraviolet colorimetry.

\subsubsection{Sulfides}

Method 9030 (SW-846) is used to measure the concentration of total and dissolved sulfides. The samples are treated with zinc acetate to produce zinc sulfide. Excess iodine is added to oxidize the sulfide to sulfur under acid conditions. The excess iodine is back titrated with sodium thiosulfate or phenylarsine oxide. 


\subsection{Volatile Organic Compound Analyses}

Methods $8010 / 8020,8240,8260$ (SW-846) or Method 524.2 (EPA-600/R-95-131) are used to analyze volatile organic compounds by gas chromatography. Volatile organic compounds are extracted from the water sample using a purge-and-trap system (e.g., Method 5030 [SW-846]). Purged sample components are trapped in a tube containing suitable sorbent materials. When purging is complete, the sorbent tube is heated and backflushed with helium to desorb trapped sample components onto a gas chromatography column. The column separates the analytes, which are then detected with either a photoionization detector or a halogen-specific detector placed in series for Methods 8010/8020. For Methods 524.2, 8240, and 8260 , the compounds are identified and quantified using a mass spectrometer.

Non-halogenated volatile organic compounds are determined by Method 8015 (SW-846). Samples are introduced into the gas chromatograph using the purgeand-trap system (Method 5030 [SW-846]). Detection is achieved by a flame ionization detector.

Field-screening methods for volatile organic compounds by gas chromatography are based on Method 8010 (SW-846).

\subsection{Semivolatile Organic Compound Analyses}

Method 8270 (SW-846) is used to analyze semivolatile organic compounds after extraction into methylene chloride, using a fused-silica capillary column. Polynuclear aromatic hydrocarbons, chlorinated hydrocarbons and pesticides, phthalate esters, organophosphate esters, nitrosamines, haloethers, aldehydes, ethers, ketones, anilines, pyridines, quinolines, aromatic nitro compounds, and phenols (including nitrophenols) can be analyzed using this method.

Method 8040 (SW-846), which specifies gas chromatographic conditions, is used to determine phenolic compounds. Samples are extracted, using methylene chloride, and then injected into the gas chromatograph, using the solvent-flush technique. The compounds in the gas chromatograph effluent are detected by a flame ionization detector. This method also provides for the preparation of pentafluorobenzyl-bromide derivatives, with additional cleanup procedures for electron-capture gas chromatography.

Method 8080 (SW-846) is used to determine polychlorinated biphenyl compounds and organochloride pesticides. This method specifies gas chromatographic conditions for detection. Prior to analysis, appropriate sample-extraction techniques are used. Both neat and diluted organic liquids may be analyzed by direct injection. A 2-to 5-milliliter sample is injected into a gas chromatograph, using the solvent-flush technique, and separated compounds are detected by an electroncapture detector or an electrolytic conductivity detector.

Method 8082 (SW-846) is also used to determine polychlorinated biphenyl compounds. The samples are extracted by an appropriate technique and analyzed by injecting a 2 -microliter aliquot into the gas chromatograph with a narrow or wide bore fused silica capillary column and electron capture detector. This method is not good for pesticide analysis due to the sample potentially being subjected to sulfuric acid/ potassium permanganate cleanup.

Herbicides are determined by Method 8150 (SW-846), which specifies extraction, esterification, and gas chromatographic conditions. Spiked samples are used to verify the applicability of the chosen extraction technique to each new sample type. The esters are hydrolyzed with potassium hydroxide, and extraneous organic material is removed by a solvent wash. After acidification, the acids are extracted with solvent and converted to their methyl esters using diazomethane as the derivation agent. After the excess reagent is removed, the esters are determined by gas chromatography, employing electron capture, microcoulometric, or electrolytic conductivity detectors. The results are reported as the acid equivalents. 
Dioxins and dibenzofurans are determined by Method 8280 (SW-846). This method involves matrix-specific extraction, analyte-specific cleanup, and high-resolution capillary column gas chromatography/ low resolution mass spectrometry techniques.

\subsection{Metals Analyses}

\subsubsection{Atomic Absorption}

The following SW-846 methods are used to analyze samples for arsenic (7060), cadmium (7131), chromium (7191), lead (7421), selenium (7740), and thallium (7841) after acid digestion. Method 236.2 (EPA-600/4-79-020) is used for iron analysis. Samples are introduced into the pyrolitic graphite chamber and atomized. Background subtraction techniques are used to correct for absorbance or scatter of light.

Method 218.2 (EPA-600/4-79-020) was used to analyze chromium by flame atomic absorption analysis after digestion. The samples are atomized by direct aspiration into the flame.

Method 7470 (SW-846), a cold vapor atomic absorption technique, is based on the absorption of radiation at 253.7 nanometers by mercury vapor. The mercury is reduced to the elemental state and aerated from solution in a closed system. The mercury vapor passes through a cell positioned in the light path of an atomic absorption spectrophotometer. Absorbance (peak height) is measured as a function of mercury concentration.

\subsubsection{Inductively Coupled Plasma Atomic Emission Spectroscopy}

Before analysis by Methods 3010 or 3015 (SW-846), samples are acid digested and then injected into a plasma following Method 6010 (SW-846) or Methods 200.7 or 200.8 (EPA-600/R-94-111). Metal concentrations are determined by inductively coupled atomic emission spectroscopy (Methods 6010 and 200.7) and by inductively coupled atomic emission spectroscopy/mass spectroscopy for Method 200.8.

\subsubsection{Hexavalent Chromium}

Method 7196 (SW-846) is used in the laboratory and in the field to determine hexavalent chromium by colorimetry. An excess of diphenylcarbazide yielded the red-violet product, and its absorbance is measured photometrically at 540 nanometer.

\subsection{Radiological Parameters}

The methods described below are typical for most analyses, but each laboratory may use a slightly different, or modified, process.

\subsubsection{Americium-241}

Americium and curium are concentrated in the sample by co-precipitation on ferric hydroxide. Thorium and plutonium are separated from the americium and curium as the sample passes through an anionexchange resin column conditioned with dilute nitric acid. The iron is then separated from the americium and curium by co-precipitation on calcium oxalate. The americium and curium are then extracted into a bidentate organophosphorus solvent (DDCP; dibutyl $\mathrm{N}, \mathrm{N}$-diethylcarbamylphosphonate) from a nitric acid solution and then backextracted with weak nitric acid. Traces of iron, thorium, and any organic residue are removed by passing the solution through a cationexchange resin column. The americium and curium are eluted from the cation-exchange resin column with dilute hydrochloric acid, electrodeposited or precipitated on a counting disk, and counted by alpha spectrometry.

\subsubsection{Carbon-14}

The carbon in a sample is converted to carbon dioxide through oxidizing and distillation. The carbon dioxide is converted to salts of carbonic acid. The carbonates are then precipitated as barium carbonate and counted by liquid scintillation. 


\subsubsection{Gamma Spectrometry}

Gamma scans provide a quantitative assay for a large number of gamma-emitting isotopes with a range of half-lives. Because these assays are performed by high-resolution counting techniques, it is possible to identify isotopes of interest with a high degree of confidence. In addition, a software library search is conducted to identify unknowns. The routinely reported isotopes include cobalt- 60 , ruthenium-106, antimony125, and cesium-137; numerous other isotopes are reported when detected. Laboratory-specific methods are used.

Samples are counted directly, following Method 901.1 (EPA-600/4-80-032) or a laboratory specific method, using an intrinsic (hyperpure) germanium or lithium-drifted germanium detector. Isotopes with gamma-ray energies from 60 to $2,000 \mathrm{KeV}$ are detected. Activity concentrations are determined using a laboratory computer system-supplied isotope library.

\subsubsection{Gross Alpha and Gross Beta}

Methods 9310 (SW-846) or 900.0 (EPA-600/480-032) are used to determine gross alpha and gross beta concentrations. An aliquot of water is evaporated onto a stainless steel counting planchet. The residue is dried to constant weight and counted for alpha and beta radioactivity. Activity is determined using a standardized counting efficiency versus sample solids curve for the detector system. Efficiencies are determined using strontium/yttrium-90 and americium-241 certified standards.

\subsection{5 lodine-129}

Iodine-129 analyses present a particular challenge because of the need for especially sensitive measurements. The iodine-129 interim drinking water standard is $1 \mathrm{pCi} / \mathrm{L}$ - the lowest for any radionuclide (40 CFR 141). The contractual detection limit is $1 \mathrm{pCi} / \mathrm{L}$ for the most sensitive method used by the primary radiological laboratory.
Iodine isotopes are first separated from interfering radioactive isotopes by oxidation to iodine $\left(\mathrm{I}_{2}\right)$ with sodium nitrite and then extracted into carbon tetrachloride from dilute acid media. The iodine is next reduced to iodide with sodium bisulfite. The iodide is then backextracted into water, precipitated as silver iodide, and counted on a low-energy photon detector. Chemical yield is determined gravimetrically.

\subsubsection{Neptunium-237}

First, neptunium is co-precipitated on lanthanum fluoride. The neptunium is then extracted in 2-thenoyltrifluoroacetone (TTA) in xylene, electrodeposited, and counted through alpha energy analysis.

\subsubsection{Nickel-63}

A nickel carrier is added to the sample. Separation of iron from the sample is performed using extraction chromatography or ion exchange. The sample is finally purified through extraction chromatography and counted by liquid scintillation.

\subsubsection{Plutonium Isotopes}

The sample is acidified with nitric acid, the plutonium oxidation state was adjusted to +4 with sodium nitrite, and the solution is loaded onto an anionexchange resin column. The plutonium is eluted with hydrochloric acid and ammonium iodide. The sample is electrodeposited or co-precipitated on a counting disk, and the activity counted by alpha spectrometry.

\subsubsection{Radiostrontium}

Method 905.0 (EPA-600/4-80-032) or a laboratory specific method is used for radiostrontium analysis. Samples are precipitated first as a nitrate and then as a carbonate. Calcium, barium, lead, and radium are removed by co-precipitation on barium chromate. Iron and other fission products are removed through hydroxide scavenging. The gravimetric yield of carrier (or strontium- 85 tracer yield) is determined along with the total radiostrontium activity by beta counting, following final carbonate precipitation. For strontium-90 
and/or strontium- 89 determination, yttrium- 90 is separated from the strontium by hydroxide and oxalate precipitations. The yttrium oxalate is converted to yttrium oxide, weighed for chemical recovery, and counted by beta-proportional counting for activity.

\subsubsection{Technetium-99}

The technetium-99 samples are wet ashed with nitric acid and hydrogen peroxide to destroy organic material in the sample. Actinides, lanthinides, alkaline earths, transition metals, and lead are removed through precipitation as hydroxides and carbonates. Technetium, as the pertechnetate ion, is adsorbed from a weak nitric acid solution on a strongly basic anion-exchange resin column. The technetium is then eluted with a stronger nitric acid solution and determined by liquid scintillation beta counting.

\subsubsection{Total Alpha - Radium}

Method 9315 (SW-846) is used to determine the total radium alpha activity. Radium is co-precipitated in water samples with mixed barium and lead sulfates. The carriers are added to an alkaline solution containing citrate, which prevented precipitation during carrier exchange with radium isotopes in the sample. Ammonium sulfate is then used to precipitate the sulfates, which were purified by nitric acid washes. The precipitate is dissolved in an alkaline solution containing EDTA (disodium ethylenedinitriloacetate dihydrate), and the barium and radium sulfates are precipitated by addition of acetic acid, thus separating radium from lead and other radionuclides. The precipitate is dried on a plate, weighed to determine chemical yield, and alpha counted to determine the activity concentration of the radium isotopes.

\subsubsection{Uranium - Total}

Total uranium analyses are performed by fluorometric or laser kinetic phosphorimetry or by alphacounting determinations of individual isotopes for activity.
Method 908.1 (EPA-600/4-80-032) is the fluorometric determination of uranium in water. The sample is preconcentrated with aluminum phosphate. The sample is then fused with sodium fluoride and then read in a fluorometer. The technique of standard additions is used by adding a known quantity of uranium to each sample.

In the laser kinetic phosphorimetry method, the water samples are pretreated for organic and halidequenching interferants (if necessary) and the particulates filtered out. The uranium is complexed with a substance such as phosphoric acid for it to phosphoresce. The concentration is calculated based on the phosphorescence of the sample in a laser phosphorimeter.

In the field, laser kinetic phosphorimetry, using instrument manufacturer's and company-specific methods, is used for total uranium determination.

\subsubsection{Tritium}

Laboratory-specific methods or Method 906.0 (EPA-600/4-80-032) are used. Sodium hydroxide is added to the tritium sample. The alkaline sample is then distilled, and a fraction (10 milliliters) mixed with scintillation cocktail, allowed to sit while the chemiluminescence decayed, and then counted by liquid scintillation instrumentation.

\subsubsection{Tritium - Low-Level}

The sample is distilled in the presence of potassium permanganate to eliminate solids and organic material that may cause quenching. The sample is then enriched in a basic medium by electrolysis to a small volume. The enriched volume is transferred to a liquid-scintillation vial with scintillation cocktail and allowed to sit for 24 hours while the chemiluminescence decays and temperature equilibrium is reached. The sample is then counted by liquid scintillation instrumentation. 


\subsubsection{Uranium Isotopes}

Uranium is separated from lead, radium, and thorium on a hydrochloric acid anion-exchange resin column; iron is removed by passing the sample through a nitric acid anion-exchange resin column. The uranium fraction is eluted and electrodeposited on a disk for alpha spectrometry counting. 
Table 8.1. Methods Used to Obtain Routine Data Results for Project Samples

\section{_... Analytical Test}

Alkalinity

Chemical oxygen demand

Coliform

Dissolved oxygen

Oil/grease

$\mathrm{pH}$

Specific conductance

Temperature

Total carbon

Total dissolved solids

Total organic carbon

Total organic halides

Total petroleum hydrocarbons

Turbidity

Ammonium ion
User $^{(a)}$

\section{General Chemical Analyses}

$G, E$

G

G

F

$\mathrm{G}, \mathrm{E}$

L

F

F

G, L

$\mathrm{F}$

F

G

G, E

G, L G

G, E

G

E

$\mathrm{L}$

F

F

Method 9131 (SW-846)

Method 9070 (SW-846)

Method 9040 (SW-846)

Company specific

Method 9050 (SW-846)

Company specific

Method 9060 (SW-846)

Method 9020 (SW-846) (Ecology 1992)

Method 8015 (SW-846)
Method 310.1 (EPA-600/4-79-020)

Method 410.4 (EPA-600/4-79-020)

Method 360.1 (EPA-600/4-79-020)

Method 413.1 (EPA-600/4-79-020)

Method 150.1 (EPA-600/4-79-020)

Method 120.1 (EPA-600/4-79-020)

Method 415.1 (EPA-600/4-79-020)

Method 160.1 (EPA-600/4-79-020)

Method 415.1 (EPA-600/4-79-020)

WTPH-Gasoline and diesel

Method 418.1 (EPA-600/4-79-020) or WTPH-Gasoline (Ecology 1992)

Method 214A (APHA 1985)

Method 180.1 (EPA-600/4-79-020)

Ammonia, Anions, and Cyanide

G, E
Anions

$\mathrm{E}$

L

G, E, L

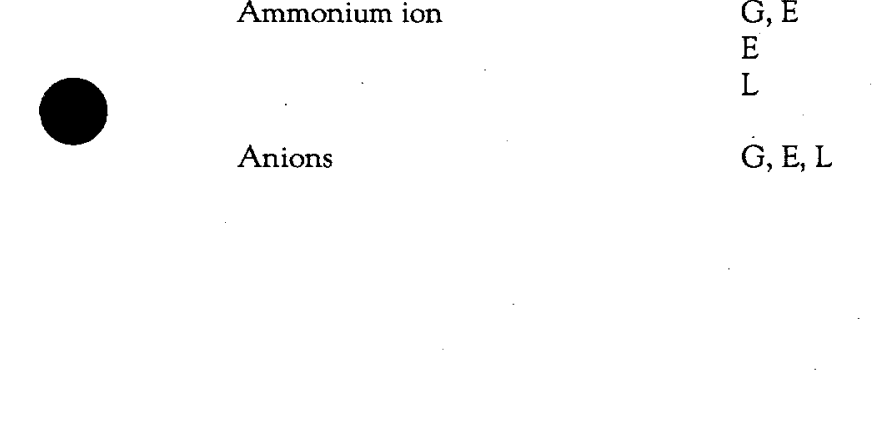

Analytical Methods

Electrochemical titration

Spectrophotometry

Tube fermentation technique

Membrane electrode

Gravimetric/separatory funnel extraction

Gravimetric/separatory funnel Extraction

Potentiometric measurement

Electrical conductance

Electronic digital thermometer

Carbon analyzer

Dried to $180^{\circ} \mathrm{C}$ and gravimetric technique

Carbon analyzer

Electrolytic titration

Gas chromatography/flame ionization detector

Spectrophotometric, infrared or gas chromatography/flame ionization detector

Purge and trap/gas chromatography/ Flame ionization detector

Nephelometric

Colorimetric Ion-selective electrode Ion chromatography 
Table 8.1. (contd)

\begin{tabular}{|c|c|c|}
\hline Analytical Test & User $^{(a)}$ & Reference \\
\hline Nitrogen, nitrate-nitrite ${ }^{(\mathbf{b})}$ & & $\begin{array}{l}\text { Method } 353.1 \text { (EPA-600/4-79-020) } \\
\text { Method } 353.2 \text { (EPA-600/4-79-020) }\end{array}$ \\
\hline Cyanide & $\begin{array}{l}G \\
L\end{array}$ & $\begin{array}{l}\text { Method } 9012 \text { (SW-846) } \\
\text { Method } 335.3(\text { EPA-600/4-79-020) }\end{array}$ \\
\hline Sulfides & G & Method 9030 (SW-846) \\
\hline & \multicolumn{2}{|c|}{ Volatile Organic Compound Analyses } \\
\hline Nonhalogenated volatile organics & $E, L$ & Method 8015 (SW-846) \\
\hline \multirow[t]{2}{*}{ Volatile organic compounds } & $\begin{array}{l}\text { G, F } \\
E \\
G, E, L \\
G\end{array}$ & $\begin{array}{l}\text { Method } 8010 / 8020 \text { (SW-846) } \\
\text { Method } 8240 \text { (SW-846) } \\
\text { Method } 8260 \text { (SW-846) } \\
\text { Method } 524.2 \text { (EPA-600/R-95-131) }\end{array}$ \\
\hline & \multicolumn{2}{|c|}{ Semivolatile Organic Compound Analyses } \\
\hline Phenols & $\mathrm{G}$ & Method 8040 (SW-846) \\
\hline $\begin{array}{l}\text { Polychlorinated biphenyls and } \\
\text { pesticides }\end{array}$ & G & Method 8080 (SW-846) \\
\hline Polychlorinated biphenyls & $\mathrm{G}$ & Method 8082 (SW-846) \\
\hline Pesticides & $\mathrm{G} ?$ & Method 8180 (SW-846) \\
\hline Herbicides & $\mathrm{G}$ & Method 8150 (SW-846) \\
\hline Semivolatile organic compounds & $\mathrm{G}, \mathrm{E}, \mathrm{L}$ & Method 8270 (SW-846) \\
\hline
\end{tabular}

Dioxins and dibenzofurans

$\mathrm{G}$ ?

Method 8280 (SW-846)

Gas chromatography

Gas chromatography

Gas chromatography

Gas chromatography

Gas chromatography

Gas chromatography/mass spectroscopy

High-resolution gas chromatography/ Low-resolution mass spectrometry

\section{Metals Analyses}

Arsenic

G, E Method 7060 (SW-846)

Graphite furnace atomic absorption

Cadmium

Chromium

E

G

G, E, L Method 6010 (SW-846)

Inductively coupled plasma atomic emission spectroscopy metals

Hexavalent chromium

Iron

E

E, G, F

E
G

Method 7131 (SW-846)
Method 218.2 (EPA-600/4-79-020) Method 7191 (SW-846)

Method 200.7 (EPA-600/R-94-111) Method 200.8 (EPA-600/R-94-111)

Method 7196 (SW-846)

Method 236.2 (EPA-600/4-79-020)
Graphite furnace atomic absorption

Flame atomic absorption

Graphite furnace atomic absorption

Inductively coupled plasma, atomic emission spectrometry
Inductively coupled plasma, mass spectrometry

Co-precipitation and atomic absorption

Graphite furnace atomic absorption 
Table 8.1. (contd)

Analytical Test
Lead
Mercury
Selenium
Thallium
Americium-241
Carbon-14
Gamma spectrometry
Gross alpha and gross beta

Iodine-129

Isotopic plutonium

Neptunium-237

Nickel-63

Radiostrontium

Strontium-90

Technetium-99

Total alpha - radium

Tritium - low level

Uranium - isotopic
User ${ }^{(a)}$

G

G, E

G, E

G

G, E

G

G, L

E

G

G

G

E

G

G

G, E

Laboratory specific

G, E

G, E, L $\quad 9315$ (SW-846)

G, E, L Laboratory specific

G

Laboratory specific

Laboratory specific

Laboratory specific

Laboratory specific

Laboratory specific
Laboratory specific
Reference

Method 7421 (SW-846)

Method 7470 (SW-846)

Method 7740 (SW-846)

Method 7841 (SW-846)

\section{Radiological Analyses} Method 901.1 (EPA-600/4-80-032)

Method 9310 (SW-846) Method 900.0 (EPA-600/4-80-032)

Laboratory specific

Method 8040 (SW-846)

Method 905.0 (EPA-600/4-80-032)
Analytical Methods

Graphite furnace atomic absorption

Cold vapor furnace atomic absorption

Graphite furnace atomic absorption

Graphite furnace atomic absorption

Anion- and cation-exchange resin separation with alpha energy analysis

Separation and liquid scintillation counting

Intrinsic germanium counting

Gas-flow proportional counting

Chemical separation, co-precipitated, and counted on low-energy photon detector

Anion-exchange resin separation with alpha energy analysis

Liquid-liquid separation and alpha energy analysis

Separation and liquid scintillation counting

Gas chromatography

Nitrate and carbonate co-precipitation, gravimetric yield, and beta gas-flow-proportional counting

Anion-exchange resin column separation with liquid scintillation counting

Co-precipitation and alpha counting

Electrolysis to enriched volume and liquid scintillation counting

Anion-exchange resin separation with alpha energy analysis 
Table 8.1. (contd)

\begin{tabular}{|c|c|c|c|}
\hline Analytical Test & $\underline{U_{s e r}^{(a)}}$ & Reference & Analytical Methods \\
\hline \multirow[t]{2}{*}{ Uranium - total } & $\mathrm{G}, \mathrm{E}$ & Laboratory specific & $\begin{array}{l}\text { Laser kinetic phosphorimetry or } \\
\text { fluorophotometry }\end{array}$ \\
\hline & $\mathrm{F}$ & Company specific & Laser kinetic phosphorimetry \\
\hline Tritium & $\begin{array}{l}\mathrm{G}, \mathrm{E} \\
\mathrm{G}, \mathrm{E}\end{array}$ & $\begin{array}{l}\text { Laboratory specific } \\
\text { Method } 906.0 \text { (EPA-600/4-80-032) }\end{array}$ & $\begin{array}{l}\text { Distillation and liquid scintillation } \\
\text { counting }\end{array}$ \\
\hline
\end{tabular}

(a) $\mathrm{E}=$ Environmental Restoration Contractor, Bechtel Hanford, Inc.

$F=$ Field (all contractors).

$\mathrm{G}=$ Groundwater Monitoring Project, Pacific Northwest National Laboratory.

$\mathrm{L}=$ Liquid Waste-Processing Facilities, Waste Management Federal Services of Hanford, Inc.

(b) Also analyzed by anion methods.

WTPH = Washington total petroleum hydrocarbons. 


\subsection{Glossary of Quality Assurance and Quality Control Terms}

accuracy - closeness of agreement between an observed value and a true value. Accuracy is assessed by means of reference samples and percent recoveries. Laboratory matrix spikes; laboratory control samples; EPA water pollution, water supply, and interlaboratory comparison programs; and blind standards are all used to assess accuracy.

blind standard - sample that contains a concentration of analyte known to the supplier but unknown to the analyzing laboratory. The analyzing laboratory is informed that the sample is a QC sample and not a field sample. Blind, double blind, and matrix-matched double-blind standards are used to evaluate analytical accuracy and precision as a measure of laboratory performance.

comparability - degree to which one set of data can be compared to another. For example, the results from samples analyzed by more than one laboratory may or not be comparable. Ideally, comparability should be evaluated using identical samples to ensure that valid comparisons can be made.

completeness - amount of acceptable data divided by the total number of data points. The Hanford Groundwater Monitoring Project determines completeness by calculating the number of unflagged data resulting from the validation process, dividing the total number of data evaluated, and multiplying by 100 . The calculated percentages used in reporting completeness are conservative because all data flagged with $B, H, Q, R$, and $Y$ (see flags) are used in calculating the percentage complete; however, flagged data may still be valid.

contractually required quantitation limit - value that represents the lowest analyte concentration in a given matrix that the laboratory must be able to achieve consistently. This value is agreed on in the contract statement of work. double-blind standard - sample that contains a concentration of analyte known to the supplier but unknown to the analyzing laboratory. The analyzing laboratory is not informed that the sample is a QC sample. All attempts are made to make this sample appear like a field sample. For example, the doubleblind standard should be submitted to the laboratory within the same time period and with a sample identification number similar to that of the field samples. The double-blind standard may or may not include matrix matching. Blind, double-blind, and matrixmatched double-blind standards are used to assess accuracy and precision as a measure of laboratory performance.

equipment blank - sample that contains Type II reagent water and any required preservative(s). An equipment blank is filled by pumping or washing Type II reagent water through a non-dedicated pump or manifold. The equipment blank is analyzed for all constituents scheduled for the sampling event.

field duplicate sample - replicate sample to determine the repeatability of the sampling and analytical measurement process by comparing results with an identical sample collected at the same time and location. Matching field duplicate samples are stored in separate containers and are analyzed independently by the same laboratory.

field trip blank - sample that contains Type II reagent water and any required preservative(s). At the time of sample collection, the field trip blank is filled at the sampling site by pouring Type II reagent water from a cleaned container into vials. After collection, the field trip blank is treated in the same manner as the other samples collected during the sampling event. Field trip blanks are collected only on days when other 
samples are collected for volatile organics analysis and are analyzed only for volatile organic constituents.

flag(s) - codes that alert data users to limitations on reported data values. In general, data flags are assigned by onsite data management personnel. An exception is the B flag that is assigned by the analytical laboratory. The flags that are used include the following:

- B - data associated with contamination in the laboratory method blank

- F - suspect data currently under review

- $\mathrm{H}$ - laboratory holding time exceeded

- G - reviewed data considered valid

- P - potential problem (with the sample or well that may have affected the data)

- Q - result associated with suspect field QC data

- $\mathrm{R}$ - reviewed data are unusable

- Y - reviewed data continue to be suspect.

full trip blank - sample that contains only Type II reagent water and preservative, as required. A full trip blank is used to check for contamination in sample bottles and sample preparation. The full trip blank is analyzed for all constituents of interest and is collected in all types of sample bottles used during that sampling period. The frequency of collection for a full trip blank is 1 per 20 samples, or 1 per sampling batch. A full trip blank is filled in the field sampling laboratory using the same sample-preparation procedures as for regular well samples. The full trip blank is not opened in the field.

laboratory control sample - sample of Type II reagent water spiked with known amounts of the target analyte(s). The sample is extracted (if appropriate) and analyzed to monitor the performance of the analytical method.

limit of detection - lowest concentration level statistically different from a blank. The limit of detection is calculated from the average blank signal plus three standard deviations for the blank analyses. limit of quantitation - level above which quantitative results may be obtained with a $95 \%$ probability that the true concentration of the analyte is within $\pm 25 \%$ of the measured concentration. The limit of quantitation is calculated from the blank mean plus 10 standard deviations of the blank.

matrix duplicate - replicate analysis of a regular (i.e., groundwater) sample. Matrix duplicates and matrix spike duplicates are used to evaluate the precision of an analysis.

matrix-matched double-blind standard - sample prepared to contain a concentration of analyte known to the supplier but unknown to the analyzing laboratory. The sample matrix is selected to closely match that of the field samples. Matrix-matched double-blind standards are disguised to appear as regular well samples to help ensure that any analyses performed are representative of those for routine well samples.

matrix spikes/matrix spike duplicates - sample(s) prepared by adding known quantities of one or more target analytes to a sample prior to extraction and analysis. Comparison of the original (i.e., unspiked) sample and matrix spike results provides information about the suitability of an analysis for the sample matrix. For example, unusually high or low recoveries of spiked compounds may indicate that components in the matrix interfere with the analysis. Matrix spike duplicates are replicate matrix spike samples that are used to assess the precision of an analysis.

method blank - sample of Type II reagent water prepared in the laboratory, extracted (if appropriate), and analyzed as if it were a regular sample. Method blanks are used to monitor the possible introduction of contaminants during sample preparation and analysis.

method detection limit - minimum concentration of a substance measurable with $99 \%$ confidence that the analyte concentration is greater than zero. The method detection limit is determined from replicate analyses of a low-level standard containing the analyte in a given matrix type. 
minimum detectable activity - lowest level of activity practically achievable by a radiochemistry counting measurement system.

precision - agreement among individual measurements of the same property, usually under prescribed similar conditions. For a set of duplicate measurements, precision is calculated by the relative percent difference of the duplicate results. For Hanford Groundwater Monitoring Project samples, results from laboratory duplicates, matrix spike duplicates, blind standards, and field duplicates are used to evaluate precision.

relative percent difference (RPD) - calculated as follows:

$$
\mathrm{RPD}=\frac{\left|\mathrm{D}_{1}-\mathrm{D}_{2}\right|}{\left(\mathrm{D}_{1}+\mathrm{D}_{2}\right) \div 2} \times 100
$$

where $D_{1}=$ original sample value $\mathrm{D}_{2}=$ duplicate sample value.

reliable detection level - limit set at two times the method detection limit so the risk of both false-positives and false-negatives falls below $1 \%$.

representativeness - expression of the degree to which samples represent the actual composition of the groundwater in the aquifer. Representativeness is addressed qualitatively by the specification of well construction, sampling locations, sampling intervals, and sampling and analysis techniques addressed in monitoring plans.

split samples - replicate samples sequentially collected from the same location and analyzed by different laboratories. To help ensure split samples are identical in composition, the samples are only collected after adequate well purging has occurred (i.e., field measurements of specific conductance and turbidity indicate the composition of pumped well water has stabilized). surrogates - organic compounds similar to analytes of interest in chemical composition, extraction, and analytical properties, but which are not normally found in environmental samples. Surrogates are spiked into method blanks, samples, and matrix spikes and are then extracted and analyzed to monitor the effectiveness of sample preparation and analysis on individual samples.

Type II reagent water - distilled or deionized water free of contaminants that may interfere with the analytical test. 
-

- 


\subsection{References}

40 CFR 141, Code of Federal Regulations, Title 40, Part 141, National Primary Drinking Water Regulations.

40 CFR 143, Code of Federal Regulations, Title 40, Part 143, National Seconidary Drinking Water Regulations.

40 CFR 257, Code of Federal Regulations, Title 40, Part 257, Criteria for Classification of Solid Waste Disposal Facilities and Practices.

40 CFR 264, Code of Federal Regulations, Title 40, Part 264, Standards for Ouners and Operators of Hazardous Waste Treatment, Storage, and Disposal Facilities.

40 CFR 265, Code of Federal Regulations, Title 40, Part 265, Interim Status Standards for Owners and Operators of Hazardous Waste Treatment, Storage, and Disposal Facilities.

40 CFR 300, Code of Federal Regulations, Title 40, Part 300, National Oil and Hazardous Substances Pollution Contingency Plan.

Allison, I. S. 1933. "New Version of the Spokane Flood." Geological Society of America Bulletin 44:675-722.

American Public Health Association (APHA). 1985. Standard Methods for the Examination of Water and Wastewater, 16th Edition. New York.

American Society for Testing and Materials. 1986. Annual Book of ASTM Standards. Philadelphia, Pennsylvania.

American Society for Testing and Materials. 1988. "D 4750-87, Standard Method for Determining Subsurface Liquid Levels in a Borehole or Monitoring Well (Observation Well)." Annual Book of ASTM Standards. Philadelphia, Pennsylvania.

American Society for Testing and Materials. 1996. "PS 64-96, Provisional Standard Guide for Developing
Appropriate Statistical Approaches for Ground-Water Detection Monitoring Programs." Annual Book of ASTM Standards. West Conshohocken, Pennsylvania.

ARH-2207. 1971. 216-Z-9 Crib History and Safety Analysis. K. R. Ridgway, M. D. Veatch, and D. T. Crawley. Atlantic Richfield Hanford Company, Richland, Washington.

ARH-2915. 1973. Nuclear Reactivity Evaluations of 216-Z-9 Enclosed Trench. A. E. Smith. Atlantic Richfield Hanford Company, Richland, Washington.

Baker, V., B. N. Bjornstad, A. J. Busacca, K. R. Fecht, E. P. Kiver, U. L. Moody, J. G. Rigby, D. F. Stradling, and A. M. Tallman. 1991. "Quaternary Geology of the Columbia Plateau." In Morrison, R. B. (ed.), Quaternary Nonglacial Geology; Conterminous U.S. The Geological Society of America, v. K-2, p. 215-250.

Bear, J. 1979. Hydraulics of Groundwater. McGraw Hill Publishing Company, New York.

BHI-00079. 1996. Groundwater Protection Plan for the Environmental Restoration Disposal Facility. D. C. Weekes, G. K. Jaeger, W. J. McMahon, and B. H. Ford. Bechtel Hanford, Inc., Richland, Washington.

BHI-00127. 1995. 100-H Area Technical Baseline Report. D. Deford and M.W. Einan. Bechtel Hanford, Inc., Richland, Washington.

BHI-00184. 1995. Miocene- to Pliocene-Aged Suprabasalt Sediments of the Hanford Site, South-Central Washington. K. A. Lindsey. Bechtel Hanford, Inc., Richland, Washington.

BHI-00720, Rev. 2. 1998. Performance Evaluation Report for Soil Vapor Extraction Operations at the Carbon Tetrachloride Site, February 1992 - September 1997. V. J. Rohay. Bechtel Hanford, Inc., Richland, Washington. 
BHI-00917. 1996. Conceptual Site Models for Groundwater Contamination at 100-BC-5, 100-KR-4, 100-HR-3, and 100-FR-3 Operable Units. R. E. Peterson, R. F. Raidl, and C. W. Denslow. Bechtel Hanford, Inc., Richland, Washington.

BHI-01105. 1997. Rebound Study Report for the Carbon Tetrachloride Soil Vapor Extraction Site, Fiscal Year 1997. V. J. Rohay. Bechtel Hanford, Inc., Richland, Washington.

CERCLA - Comprehensive Environmental Response, Compensation, and Liability Act of 1980, as amended, Public Law 96-510, 94 Stat. 2767, 42 USC 9601 et seq.

Cameron, K.M.D. 1996. "RCRA Leapfrog: How Statistics Shape and in Turn are Shaped By Regulatory Mandates." Remediation 7(1):15-25.

Chou, C. J. 1991. "Statistical Approach on RCRA Groundwater Monitoring Projects at the Hanford Site." In American Statistical Association 1991 Proceedings of the Section on Statistics and the Environment. Alexandria, Virginia, pp. 326-241; also, WHC-SA-1124-FP, Westinghouse Hanford Company, Richland, Washington.

Conover, W. J. 1980. Practical Nonparametric Statistics, Second Edition. John Wiley and Sons, Inc., New York, pp. 118-121, 346-363.

Davis, C. B. 1994. "Environmental Regulatory Statistics." In Environmental Statistics, Handbook of Statistics, Volume 12, (Eds. G. P. Patil and C. R. Rao), NorthHolland, New York, pp. 817-865.

DOE Order 5400.1. General Environmental Protection Program. U.S. Department of Energy, Washington, D.C.

DOE Order 5400.5. Radiation Protection of the Public and the Environment. U.S. Department of Energy, Washington, D.C.

DOE Order 5820.2. Radioactive Waste Management. U.S. Department of Energy, Washington, D.C.
DOE/EH-0173T. 1991. Environmental Regulatory Guide for Radiological Effluent Monitoring and Environmental Surveillance. Assistant Secretary for the Environment, Safety, and Health, U.S. Department of Energy, Washington, D.C.

DOE/RL-89-12, Rev. 2. 1995. Hanford Site GroundWater Protection Management Plan. D. B. Barnett, J. S. Schmid, S. S. Lowe, W. L. Allen, N. A. Ballantyne, C. H. Dohrer, M. J. Hartman, F. N. Hodges, D. G. Horton, V. G. Johnson, K. J. Lueck, D. J. Ortiz, A. J. Knepp, B. H. Ford, S. P. Hope, D. K. Tyler, R. D. Hildebrand, D. E. Olson, R. E. Peterson, G. L. Kasza, D. A. Myers, S. P. Luttrell, P. D. Thorne, and K. R. Moser. U.S. Department of Energy, Richland Operations Office, Richland, Washington.

DOE/RL-89-28, Rev. 2. 1994. 216-B-3 Expansion Ponds Closure Plan. U.S. Department of Energy, Richland Operations Office, Richland, Washington.

DOE/RL-90-17. 1990. Nonradioactive Dangerous Waste Landfill Closure/Postclosure Plan. U.S. Department of Energy, Richland Operations Office, Richland, Washington.

DOE/RL-90-18. 1990. Phase 1 Remedial Investigation Report for the Hanford Site 1100-EM-1 Operable Unit. U.S. Department of Energy, Richland Operations Office, Richland, Washington.

DOE/RL-90-38, Rev. 0. 1991. Hanford Site Solid Waste Landfill Permit Application. U.S. Department of Energy, Richland Operations Office, Richland, Washington.

DOE/RL-90-38, Rev. 1. 1996. Hanford Site Solid Waste Landfill Interim Closure Plan. U.S. Department of Energy, Richland Operations Office, Richland, Washington.

DOE/RL-91-03. 1991. Annual Report for RCRA Groundwater Monitoring Projects at Hanford Site Facilities for 1990. Prepared by Geosciences Group, Westinghouse Hanford Company, Environmental Division for U.S. Department of Energy, Richland Operations Office, Richland, Washington. 
DOE/RL-91-31, Rev. 1. 1991. Hanford Site Waste Minimization and Pollution Awareness Program Plan. U.S. Department of Energy, Richland Operations Office, Richland, Washington.

DOE/RL-91-32, Draft B. 1991. Expedited Response Action Proposal (EE/CA \& EA) for 200 West Area Carbon Tetrachloride Plume, Appendix B. V. J. Rohay and V. G. Johnson for U.S. Department of Energy, Richland Field Office, Richland, Washington.

DOE/RL-91-40. 1991. Hanford Past-Practices Strategy. K. M. Thompson, U.S. Department of Energy, Richland Operations Office, Richland, Washington.

DOE/RL-91-50, Rev. 2. 1997. Enarironmental Monitoring Plan, United States Department of Energy, Richland Operations Office. Prepared by personnel from Pacific Northwest National Laboratory, Fluor Daniel Hanford, Inc. and its subcontractor Waste Management Federal Services of Hanford, Inc., and Bechtel Hanford, Inc. for U.S. Department of Energy, Richland Operations Office, Richland, Washington.

DOE/RL-91-58. 1992. Z Plant Source Aggregate Area Management Study Report. U.S. Department of Energy, Richland Operations Office, Richland, Washington.

DOE/RL-93-88, 1994. Annual Report for RCRA Groundwater Monitoring Projects at Hanford Site Facilities for 1993. Prepared by Geosciences Group, Westinghouse Hanford Company, Environmental Division for U.S. Department of Energy, Richland Operations Office, Richland, Washington.

DOE/RL-93-99, Rev. 1. 1994. Remedial Investigation and Feasibility Study Report for the Environmental Restoration Disposal Facility. U.S. Department of Energy, Richland Operations Office, Richland, Washington.

DOE/RL-94-95, Rev. 1. 1995. Hanford Site Groundwater Remediation Strategy. U.S. Department of Energy, Richland Operations Office, Richland, Washington.

DOE/RL-94-99. 1995. Proposed Plan for Interim Remedial Measures at the 100-BC-1 Operable Unit.
U.S. Department of Energy, Richland Operations Office, Richland, Washington.

DOE/RL-94-111. 1994. Tri-Party Agreement Strategic Data Management Plan. U.S. Department of Energy, Richland Operations Office, Richland, Washington.

DOE/RL-95-54, Draft B. 1995. Proposed Plan for Interim Remedial Measures at the 100-FR-1 Operable Unit. U.S. Department of Energy, Richland Operations Office, Richland, Washington.

DOE/RL-95-66, Draft A. 1995. Proposed Plan for Interim Remedial Measures at the 100-BC-2 Operable Unit. U.S. Department of Energy, Richland Operations Office, Richland, Washington.

DOE/RL-95-92, Decisional Draft. 1995. Proposed Plan for Interim Remedial Measures at the 100-FR-2 Operable Unit. U.S. Department of Energy, Richland Operations Office, Richland, Washington.

DOE/RL-96-42. 1996. Limited Field Investigation Report for the 300-FF-2 Operable Unit. U.S. Department of Energy, Richland Operations Office, Richland, Washington.

DOE/RL-96-66. 1996. RCRA Corrective Measure Study for the 200-PO-1 Operable Unit. U.S. Department of Energy, Richland Operations Office, Richland, Washington.

DOE/RW-0164. 1988. Consultation Draft, Site Characterization Plan, Reference Repository Location, Hanford Site, Washington. U.S. Department of Energy, Richland Operations Office, Richland, Washington.

Drost, B. W., S. E. Cox, and K. M. Schurr. 1997. Changes in Ground-Water Levels and Ground-Water Budgets, from Predevelopment to 1986, in Parts of the Pasco Basin, Washington. Water-Resources Investigations Report 96-4086, U.S. Geological Survey, Tacoma, Washington.

Drummond, M. E. 1992. The Future for Hanford: Uses and Cleanup. A Final Report of the Hanford Future Site Uses Working Group. Eastern Washington University, Cheney, Washington. 
Ecology - Washington State Department of Ecology* 1992. Total Petroleum Hydrocarbons Analytical Methods. Prepared by J. Barreca, April 8, 1992, Olympia, Washington.

Ecology - Washington State Department of Ecology. 1994. Dangerous Waste Portion of the Resource Conservation and Recovery Act Permit for the Treatment, Storage, and Disposal of Dangerous Waste, as amended. Permit Number WA7890008967, Effective September 28, 1994. Olympia, Washington.

Ecology - Washington State Department of Ecology. 1995a. State Waste Discharge Permit (216 Permit) for the 200 Area Treated Effluent Disposal Facility (TEDF). Permit No. ST 4502, issued in compliance with the provisions of Chapter $90.48 \mathrm{RCW}$, as amended, and Chapter 173-216 WAC, as amended, Olympia, Washington.

Ecology - Washington State Department of Ecology. 1995b. State Waste Discharge Permit (216 Permit) for the 200 Area Effluent Treatment Facility (ETF). Permit No. ST 4500 , issued in compliance with the provisions of Chapter 90.48 RCW, as amended, and Chapter 173-216 WAC, as amended, Olympia, Washington.

Ecology - Washington State Department of Ecology. 1996a. State Waste Discharge Permit No. ST 4501 (400 Area Pond). Olympia, Washington.

Ecology - Washington State Department of Ecology. 1996b. Implementation Guidance for the Ground Water Quality Standards. Olympia, Washington.

Ecology - Washington State Department of Ecology and U.S. Environmental Protection Agency. 1994. Action Memorandum: N-Springs Expedited Response Action Cleanup Plan, U.S. Department of Energy, Hanford Site, Washington. Olympia, Washington.

Ecology - Washington State Department of Ecology, U.S. Environmental Protection Agency, and U.S. Department of Energy. 1989. Hanford Federal Facility Agreement and Consent Order, as amended (the Tri-Party Agreement). Olympia, Seattle, and Richland, Washington.
Ecology and EPA - Washington State Department of Ecology and U.S. Environmental Protection Agency. 1994. Action Memorandum: N-Springs Expedited Response Action Cleanup Plan, U.S. Department of Energy, Hanford Site, Washington. Olympia, Washington.

EPA-600/4-79-020. 1979. Methods for Chemical Analysis of Water and Wastes. U.S. Environmental Protection Agency, Washington, D.C.

EPA-600/4-80-032. 1980. Prescribed Procedures for Measurement of Radioactivity in Drinking Water. U.S. Environmental Protection Agency, Washington, D.C. EPA-530/R-93-003. 1992. Statistical Analysis of Ground-Water Monitoring Data at RCRA Facilities, Draft Addendum to Interim Final Guidance. U.S. Environmental Protection Agency, Washington, D.C.

EPA-600/R-93-100. 1993. Methods for the Determination of Inorganic Substances in Environmental Samples. U.S. Environmental Protection Agency, Washington, D.C.

EPA-600/R-94-111. 1994. Methods for the Determination of Metals in Enwironmental Samples, Supplement 1 to EPA-600/4-91-010. U.S. Environmental Protection Agency, Washington, D.C.

EPA-600/R-95-131. 1995. Methods for the Determination of Organic Compounds in Drinking Water, Supplement III. (EMSL) Supplement to EPA-600/ 4-88-039. U.S. Environmental Protection Agency, Washington, D.C.

EPA-822/R-96-001. 1996. Drinking Water Regulations and Health Advisories. Office of Water, U.S. Environmental Protection Agency, Washington, D.C.

Fecht, K. R., S. P. Reidel, and A. M. Tallman. 1987. "Paleodrainage of the Columbia River System on the Columbia Plateau of Washington State - A Summary." In Schuster, J. E. (ed.), Selected Papers on the Geology of Washington. Bulletin 77, Washington State Division of Geology and Earth Resources, Olympia, Washington, p. 219-248. 
Garber, M. S. and F. C. Koopman. 1968. Methods of Measuring Water Levels in Deep Wells: U.S. Geological Survey. TRWI, Book 8, Chapter A-1. U.S. Government Printing Office, Washington, D.C.

Gee, G. W.; M. J. Fayer, M. L. Rockhold, and M. D. Campbell. 1992. "Variations in Recharge at the Hanford Site." Northwest Science 66:237-250.

HNF-EP-0527-6. 1997. Environmental Releases for Calendar Year 1996. B. P. Gleckler, Waste Management Federal Services of Hanford Inc. for Fluor Daniel Hanford, Inc., Richland, Washington.

LA-UR-96-3860. 1997. Hanford Tank Chemical and Radionuclide Inventories: HDW Model Rev. 4. S. F. Agnew, Los Alamos National Laboratory, Los Alamos, New Mexico.

Natrella, M. G. 1966. Experimental Statistics. National Bureau of Standards Handbook 91, John Wiley \& Sons, New York, Table A-7.

Newcomb, R. C. 1958. "Ringold Formation of the Pleistocene Age in the Type Locality, The White Bluffs, Washington." American Journal of Science 256:328-340.

Newcomb, R. C., J. R. Strand, and F. J. Frank. 1972. Geology and Ground-Water Characteristics of the Hanford Reservation of the U.S. Atomic Energy Commission, Washington. Professional Paper 717, U.S. Geological Survey, Washington, D.C.

OSWER-9950.1. 1986. Resource Conservation and Recovery Act (RCRA) Groundwater Monitoring Technical Enforcement Guidance Document (TEGD). U.S. Environmental Protection Agency, Washington, D.C.

PB89-151047. 1989. Statistical Analysis of GroundWater Monitoring Data at RCRA Facilities-Interim Final Guidance. U.S. Environmental Protection Agency, Washington, D.C.

Peterson, R. E. and M. P. Connelly. 1992. "Characterization of a Chromium Plume in Groundwater Along the Columbia River Shoreline, Hanford Site,
Washington." Presented at 1992 Fall Meeting, American Geophysical Union, San Francisco, California, December 7-11, 1992. EOS Transactions, American Geophysical Union 73:43; also WHC-SA-1674-VA, Westinghouse Hanford Company, Richland, Washington.

PNL-2949. 1979. Geohydrology and Ground-Water Quality Beneath the 300 Area, Hanford Site, Washington. J. W. Lindberg and F. W. Bond. Pacific Northwest Laboratory, Richland, Washington.

PNL-6313. 1987. An Evaluation of Aquifer Intercommunication Between the Unconfined and Rattlesnake Ridge Aquifers on the Hanford Site. E. J. Jensen. Pacific Northwest Laboratory, Richland, Washington.

PNL-6456. 1988. Hazard Ranking System Evaluation of CERCLA Inactive Waste Sites at Hanford. Volume I, Evaluation Method and Results. R. D. Stenner, K. H. Cramer, K. A. Higley, S. J. Jette, D. A. Lamar, T. J. McLaughlin, D. R. Sherwood, and N. C. VanHouten. Pacific Northwest Laboratory, Richland, Washington.

PNL-6463. 1988. The Predicted Impacts to the Ground Water and Columbia River from Ammoniated Water Discharged to the 216-A-36B Crib. J.L. Buelt, W. Conbere, M.D. Freshley, R.J. Hicks, W.L. Kuhn, D.A. Lamar, R.J. Serne, and J.L. Smoot. Pacific Northwest Laboratory, Richland, Washington.

PNL-6716. 1988. Interim Characterization Report for the 300 Area Process Trenches. R. Schalla, R. W. Wallace, R. L. Aaberg, S. P. Airhart, D. J. Bates, J.V.M. Carlile, C. S. Cline, D. I. Dennison, M. D. Freshley, P. R. Heller, E. J. Jensen, K. B. Olsen, R. G. Parkhurst, J. T. Rieger, and E. J. Westergard. Pacific Northwest Laboratory, Richland, Washington.

PNL-6852. 1989. RCRA Ground-Water Monitoring Projects for Hanford Facilities: Annual Progress Report for 1988. R. M. Fruland and R. E. Lundgren (eds.). Pacific Northwest Laboratory, Richland, Washington.

PNL-8332. 1992. Status Report on the Development of a Three-Dimensional Conceptual Model for the Hanford 
Site Unconfined Aquifer System. P. D. Thorne and M. A. Chamness. Pacific Northwest Laboratory, Richland, Washington.

PNL-8337. 1992. Summary and Evaluation of Available Hydraulic Property Data for the Hanford Site Unconfined Aquifer System. P. D. Thorne and D. R. Newcomer. Pacific Northwest Laboratory, Richland, Washington.

PNL-8539. 1993. Selected Hydraulic Test Analysis Techniques for Constant-Rate Discharge Tests. F. A. Spane, Jr. Pacific Northwest Laboratory, Richland, Washington.

PNL-8580. 1993. Water Level Measurements for Modeling Hydraulic Properties in the 300-FF-5 and 100 Aggregate Area Operable Units. M. D. Campbell, W. J. McMahon, and K. R. Simpson. Pacific Northwest Laboratory, Richland, Washington.

PNL-8597. 1993. Refined Conceptual Model for the Volatile Organic Compounds - Arid Integrated Demonstration and 200 West Area Carbon Tetrachloride Expedited Response Action. G. V. Last and V. J. Rohay. Pacific Northwest Laboratory, Richland, Washington.

PNL-8971. 1993. Three-Dimensional Conceptual Model for the Hanford Site Unconfined Aquifer System, FY 93 Status Report. P. D. Thorne, M. A. Chamness, F. A. Spane, Jr., V. R. Vermeul, and W. D. Webber. Pacific Northwest Laboratory, Richland, Washington.

PNL-10094. 1994. Hydrogeology Along the Southern Boundary of the Hanford Site Between the Yakima and Columbia Rivers, Washington. T. L. Liikala. Pacific Northwest Laboratory, Richland, Washington.

PNL-10158. 1994. Summary and Evaluation of Hydraulic Property Data Available for the Hanford Site Upper Basalt Confined Aquifer System. F. A. Spane, Jr. and V. R. Vermeul. Pacific Northwest Laboratory, Richland, Washington.

PNL-10195. 1994. Three-Dimensional Conceptual Model for the Hanford Site Unconfined Aquifer System: FY 1994 Status Report. P. D. Thorne, M. A. Chamness,
V. R. Vermeul, Q. C. MacDonald, and S. E. Schubert. Pacific Northwest Laboratory, Richland, Washington.

PNL-10285. 1995. Estimated Recharge Rates at the Hanford Site. M. J. Fayer and T. B. Walters. Pacific Northwest Laboratory, Richland, Washington.

PNL-10422. 1995. Geology, Hydrology, Chemistry, and Microbiology of the In Situ Bioremediation Demonstration Site. D. R. Newcomer, L. A. Doremus, S. H. Hall, M. J. Truex, V. R. Vermeul, and R. E. Engelman. Pacific Northwest Laboratory, Richland, Washington.

PNL-10633. 1995. Geologic, Geochemical, Microbiologic, and Hydrologic Characterization at the In Situ Redox Manipulation Test Site. V. R. Vermeul, S. S. Teel, J. E. Amonette, C. R. Cole, J. S. Fruchter, Y. A. Gorby, F. A. Spane, Jr., J. E. Szecsody, M. D. Williams, and S. B. Yabusaki. Pacific Northwest Laboratory, Richland, Washington.

PNL-10817. 1995. Hydrochemistry and Hydrogeologic Conditions Within the Hanford Upper Basalt Confined Aquifer System. F. A. Spane, Jr. and W. D. Webber. Pacific Northwest Laboratory, Richland, Washington.

PNL-10835. 1995. Comparison of Constant-Rate Pumping Test and Slug Interference Test Results at the B-Pond Multi-Level Test Facility, Hanford Site. F. A. Spane, Jr. and P. D. Thorne. Pacific Northwest Laboratory, Richland, Washington.

PNL-10886. 1995. Development of a Three-Dimensional Ground-Water Model of the Hanford Site Unconfined Aquifer System: FY 1995 Status Report. S. K. Wurstner, P. D. Thorne, M. A. Chamness, M. D. Freshley, and M. D. Williams. Pacific Northwest Laboratory, Richland, Washington.

PNNL-11793. 1998. Hanford Site Groundwater Monitoring for Fiscal Year 1997. M. J. Hartman and P. E. Dresel (eds.). Pacific Northwest National Laboratory, Richland, Washington.

PNNL-11801. 1998. Three-Dimensional Analysis of Future Groundwater Flow Conditions and Contaminant Plume Transport in the Hanford Site Unconfined Aquifer 
System: FY 1996 and 1997 Status Report. C. R. Cole, S. K. Wurstner, M. P. Bergeron, M. D. Williams, and P. D. Thorne. Pacific Northwest National Laboratory, Richland, Washington.

PNNL-11986. 1998. Evaluation of Groundwater Monitoring Results at the Hanford Site 200 Area Treated Effluent Disposal Facility. D. B. Barnett. Pacific Northwest National Laboratory, Richland, Washington.

PNNL-11989. 1998. Integrated Monitoring Plan for the Hanford Groundwater Momitoring Project. M. J. Hartman, P. E. Dresel, J. P. McDonald, R. B. Mercer, D. R. Newcomer, and E. C. Thornton. Pacific Northwest National Laboratory, Richland, Washington.

PNNL-12086. 1999. Hanford Site Groundwater Monitoring for Fiscal Year 1998. M. J. Hartman (ed.). Pacific Northwest National Laboratory, Richland, Washington.

PNNL-12261. 1999. Revised Hydrogeology for the Suprabasalt Upper Aquifer System, 200-East Area, Hanford Site, Washington. B. A. Williams, B. N. Bjornstad, R. Schalla, and W. D. Webber. Pacific Northwest National Laboratory, Richland, Washington.

PNNL-13021. 1999. Water-Level Monitoring Plan for the Hanford Groundwater Monitoring Project. J. P. McDonald, M. A. Chamness, and D. R. Newcomer. Pacific Northwest National Laboratory, Richland, Washington.

Puget Sound Power and Light Company. 1982. Skagit/ Hanford Nuclear Project, Preliminary Safety Analysis Report. Appendix 20, Amendment 23, Bellevue, Washington.

RCRA - Resource Conservation and Recovery Act of 1976, as amended, Public Law 94-580-, 90 Stat. 2795, 42 USC 6901 et seq.

Record of Decision (ROD). 1995. Declaration of the Record of Decision, USDOE Hanford 200 Area, Hanford Site, Benton County, Washington (200-ZP-1). Washington State Department of Ecology, U.S. Environmental Protection Agency, and U.S. Department of Energy, Richland Operations Office, Richland, Washington.
Record of Decision (ROD). 1996a. Declaration of the Record of Decision for the 300-FF-1 and 300-FF-5 Operable Units. Washington State Department of Ecology, U.S. Environmental Protection Agency, and U.S. Department of Energy, Richland Operations Office, Richland, Washington.

Record of Decision (ROD). 1996b. Declaration of the Record of Decision, USDOE Hanford 100 Area, 100-HR-3 and 100-KR-4 Operable Units, Hanford Site, Benton County, Washington, April 1996. Washington State Department of Ecology, U.S. Environmental Protection Agency, and U.S. Department of Energy, Richland Operations Office, Richland, Washington.

Record of Decision (ROD). 1997. Declaration of the Record of Decision, U.S. DOE Hanford 200 Area, Hanford Site, Benton County, Washington (200-UP-1). Washington State Department of Ecology, U.S. Environmental Protection Agency, and U.S. Department of Energy, Richland Operations Office, Richland, Washington.

Reidel, S. P. and K. R. Fecht. 1994a. Geologic Map of the Richland 1:100,000 Quadrangle, Washington. Open File Report 94-8, Washington Division of Geology and Earth Resources, Washington State Department of Natural Resources, Olympia, Washington.

Reidel, S. P. and K. R. Fecht. 1994b. Geologic Map of the Priest Rapids 1:100,000 Quandrangle, Washington. Open File Report 94-13, Washington Division of Geology and Earth Resources, Washington State Department of Natural Resources, Olympia, Washington.

Revised Code of Washington (RCW). 70.105, Hazardous Waste Management.

Reidel, S. P., K. R. Fecht, K. A. Lindsey, and N. P. Campbell. 1994. "Late Cenozoic Structure and Stratigraphy of South-Central Washington." In Lasmanis, R. and E. S. Cheney (eds.), Washington Division of Geology and Earth Resources Bulletin 80, Olympia, Washington, p. 159-180.

RHO-BWI-C-56. 1979. A Review of Water-Well Data From the Unconfined Aquifer in the Eastern and Southem 
Parts of the Pasco Basin. R. E. Brown. Rockwell Hanford Operations, Richland, Washington.

RHO-BWI-ST-4. 1979. Geologic Studies of the Columbia Plateau: A Status Report. C. W. Myers/S. M. Price, J. A. Caggiano, M. P. Cochran, W. J. Czimer, N. J. Davidson, R. C. Edwards, K. R. Fecht, G. E. Holmes, M. G. Jones, J. R. Kunk, R. D. Landon, R. K. Ledgerwood, J. T. Lillie, P. E. Long, T. H. Mitchell, E. H. Price, S. M. Reidel, and A. M. Tallman. Rockwell Hanford Operations, Richland, Washington.

RHO-BWI-ST-14. 1981. Subsurface Geology of the Cold Creek Syncline. C. W. Myers and S. M. Price (eds.). Rockwell Hanford Operations, Richland, Washington.

RHO-HS-EV-18. 1983. Serviceability of Cribs Affected by PUREX Startup. R. M. Smith and R. B. Kasper. Rockwell Hanford Operations, Richland, Washington.

RHO-HS-SR-86-3-4Q LIQ P. 1987. Radioactive Liquid Wastes Discharged to Ground in the 200 Areas During 1986. R. C. Aldrich. Rockwell Hanford Operations, Richland, Washington.

RHO-RE-ST-12 P. 1984. An Assessment of Aquifer Intercommunication in the B Pond, Gable Mountain Pond Area. M. J. Graham, G. V. Last, and K. R. Fecht. Rockwell Hanford Operations, Richland, Washington.

RHO-ST-17. 1979. Distribution of Plutonium and Americium Beneath the 216-2-1A Crib: Status Report. S. M. Price, R. B. Kasper, M. K. Additon, R. M. Smith, and G. V. Last. Rockwell Hanford Operations, Richland, Washington.

RHO-ST-21. 1978. Report on Plutonium Mining Activities at 216-2-9 Enclosed Trench. J. D. Ludowise. Rockwell Hanford Operations, Richland, Washington.

RHO-ST-23. 1979. Geology of the Separations Areas, Hanford Site, South-Central Washington. A. M. Tallman, K. R. Fecht, M. C. Marratt, and G. V. Last. Rockwell Hanford Operations, Richland, Washington.

RHO-ST-38. 1982. Geohydrology of the Rattlesnake Ridge Interbed in the Gable Mountain Pond Area. S. R.
Strait and B. A. Moore. Rockwell Hanford Operations, Richland, Washington.

RHO-ST-44. 1982. 216-Z-12 Transuranic Crib Characterization: Operational History and Distribution of Plutonium and Americium. R. B. Kasper. Rockwell Hanford Operations, Richland, Washington.

Safe Drinking Water Act of 1974, as amended. Public Law 93-523, 88 Stat. 1660, 42 USC 300 fe seq.

SD-BWI-DP-039. 1984. Suprabasalt Stratigraphy Within and Adjacent to the Reference Repository Location. B. N. Bjornstad. Rockwell Hanford Operations, Richland, Washington.

Slate, J. L. 1996. "Buried Carbonate Paleosols Developed in Pliocene-Pleistocene Deposits of the Pasco Basin, South Central Washington, USA." In Quaternary Intermational 34-36:191-196.

Spane, F. A. Jr. 1996. "Applicability of Slug Interference Tests for Hydraulic Characterization of Unconfined Aquifers: (1) Analytical Assessment." Ground Water 34(1):66-74.

Stromswold, D. C. 1994. Calibration Facilities at Hanford for Gamma-Ray and Fission-Neutron Well Logging. PNL-9958, Pacific Northwest Laboratory, Richland, Washington.

SW-846. 1986. Test Methods for Evaluating Solid Wastes: Physical/Chemical Methods, 3rd ed. Office of Solid Waste and Emergency Response, U.S. Environmental Protection Agency, Washington, D.C.

Swanson, D. A., J. L. Anderson, R. D. Bentley, V. E. Camp, J. N. Gardner, and T. L. Wright. 1979. Reconnaissance Geologic Map of the Columbia River Basalt Group in Washington and Adjacent Idaho. Open-File Report 79-1363, U.S. Geological Survey, Washington, D.C.

U.S. Army Corps of Engineers. 1997. Corpscon, Version 5.x, Technical Documentation and Operating Instructions. Geodetic Applications Division, Topographic Applications Laboratory, U.S. Army Topographic Engineering Center, Alexandria, Virginia. 
. U.S. Geological Survey. 1997. National Handbook of Recommended Methods for Water Data Acquisition. Office of Water Data Coordination, Reston, Virginia. WAC 173-200, Washington Administrative Code. Water Quality Standards for Ground Waters of the State of Washington. Olympia, Washington.

WAC 173-216, Washington Administrative Code. State Waste Discharge Program. Olympia, Washington.

WAC 173-303, Washington Administrative Code. Dangerous Waste Regulations. Olympia, Washington.

WAC 173-303-400, Washington Administrative Code. Interim Status Facility Standards. Olympia, Washington.

WAC 173-303-600, Washington Administrative Code. Final Status Standards. Olympia, Washington.

WAC 173-303-610, Washington Administrative Code. Closure and Postclosure. Olympia, Washington.

WAC 173-303-645, Washington Administrative Code. Releases from Regulated Units. Olympia, Washington.

WAC 173-304, Washington Administrative Code. Minimum Functional Standards for Solid Waste Handling. Olympia, Washington.

WAC 173-304-490, Washington Administrative Code. Ground Water Monitoring Requirements. Olympia, Washington.

WAC 173-340, Washington Administrative Code. Model Toxics Control Act - Cleanup. Olympia, Washington.

WAC 173-340-720, Washington Administrative Code. Ground Water Cleanup Standards. Olympia, Washington.

WAC 246-290, Washington Administrative Code. Public Water Supplies. Olympia, Washington.

WHC-EP-0021. 1987. Interim Hydrogeologic Characterization Report and Groundwater Monitoring System for the Nonradioactive Dangerous Waste Landfill, Hanford
Site, Washington. D. C. Weekes, S. P. Luttrell, and M. R. Fuchs. Westinghouse Hanford Company, Richland, Washington.

WHC-EP-0674. 1993. Groundwater Impact Assessment Report for 216-Z-20 Crib, 200 West Area. V. G. Johnson. Westinghouse Hanford Company, Richland, Washington.

WHC-MR-0132. 1990. A History of the 200 Area Tank Farms. J. D. Anderson. Westinghouse Hanford Company, Richland, Washington.

WHC-MR-0206. 1990. Borehole Completion Data Package for the 216-S-10 Ditch and Pond. S. P. Airhart. Westinghouse Hanford Company, Richland, Washington.

WHC-MR-0227. 1991. Tank Wastes Discharged Directly to the Soil at the Hanford Site. J. L. Waite. Westinghouse Hanford Company, Richland, Washington.

WHC-MR-0391. 1992. Field Trip Guide to the Hanford Site. S. P. Reidel, K. A. Lindsey, and K. R. Fecht. Westinghouse Hanford Company, Richland, Washington.

WHC-SD-C018H-PLN-004, Rev. 1. 1996. GroundWater Screening Evaluation/Monitoring Plan - 200 Area Effluent Treatment Facility (Project C-018H). J. D. Davis, D. B. Barnett, C. J. Chou, and P. B. Freeman. Westinghouse Hanford Company, Richland, Washington.

WHC-SD-C018H-RPT-003. 1994. 1994 Characterization Report for the State Approved Land Disposal Site. L. C. Swanson. Westinghouse Hanford Company, Richland, Washington.

WHC-SD-EN-AP-012, Rev. 0. 1989. 40 CFR 265 Interim-Status Ground-Water Monitoring Plan for the Single-Shell Tanks. E. J. Jensen, S. P. Airhart, M. A. Chamness, T. J Gilmore, D. R. Newcomer, and K. R. Oster. Pacific Northwest Laboratory for Westinghouse Hanford Company, Richland, Washington. 
WHC-SD-EN-AP-012, Rev. 1. 1991. Interim-Status Groundwater Monitoring Plan for the Single-Shell Tanks. J. A. Caggiano and S. M. Goodwin. Westinghouse Hanford Company, Richland, Washington.

WHC-SD-EN-AP-108. 1993. Interim-Status Groundwater Quality Assessment Plan for the 216-U-12 Crib. C. J. Chou and B. A. Williams. Westinghouse Hanford Company, Richland, Washington.

WHC-SD-EN-DP-049. 1993. 1992 Borehole Completion Data Package for the Low-Level Burial Grounds. R. B. Mercer. Westinghouse Hanford Company, Richland, Washington.

WHC-SD-EN-DP-052. 1993. Borehole Completion Data Package for the 216-S-10 Facility, CY-1992. B. A. Williams and D. B. Barnett. Westinghouse Hanford Company, Richland, Washington.

WHC-SD-EN-EE-004. 1991. Revised Stratigraphy for the Ringold Formation, Hanford Site, South-Central Washington. K. A. Lindsey. Westinghouse Hanford Company, Richland, Washington.

WHC-SD-EN-EV-027. 1993. Hydrogeology of the 100-N Area, Hanford Site, Washington. M. J. Hartman and K. A. Lindsey. Westinghouse Hanford Company, Richland, Washington.

WHC-SD-EN-TA-004. 1996. Feasibility of CPTDeployed Vertical Electrode Array in Single Shell Tank Farms. S. M. Narbutovskih, D. F. Iwatate, M. D. Sweeney, A. L. Ramirez, W. Daily, R. M. Morey, and L. Christensen. Westinghouse Hanford Company, Richland, Washington.

WHC-SD-EN-TI-008. 1991. Geologic Setting of the 200 West Area: An Update. K. A. Lindsey, M. P. Connelly, and B. N. Bjornstad. Westinghouse Hanford Company, Richland, Washington.

WHC-SD-EN-TI-012. 1992. Geologic Setting of the 200 East Area: An Update. K. A. Lindsey, B. N. Bjornstad, J. W. Lindberg, and K. M. Hoffman. Westinghouse Hanford Company, Richland, Washington.
WHC-SD-EN-TI-014. 1992. Hydrogeologic Model for the 200 West Groundwater Aggregate Area. M. P. Connelly, B. H. Ford, and J. V. Borghese. Westinghouse Hanford Company, Richland, Washington.

WHC-SD-EN-TI-019. 1992. Hydrogeologic Model for the 200 East Groundwater Aggregate Area. M. P. Connelly, B. H. Ford, J. W. Lindberg, S. J. Trent, C. D. Delaney, and J. V. Borghese. Westinghouse Hanford Company, Richland, Washington.

WHC-SD-EN-TI-023. 1992. Hydrologic Information Summary for the Northern Portion of the Hanford Site. M. J. Hartman and R. E. Peterson. Westinghouse Hanford Company, Richland, Washington.

WHC-SD-EN-TI-052. 1992. Phase I Hydrogeologic Summary of the 300-FF-5 Operable Unit, 300 Area. L. C. Swanson. Westinghouse Hanford Company, Richland, Washington.

WHC-SD-EN-TI-071. 1993. Geology and Aquifer Characteristics of the Grout Treatment Facility. J. W. Lindberg, J. V. Borghese, B. N. Bjornstad, and M. P. Connelly. Westinghouse Hanford Company, Richland, Washington.

WHC-SD-EN-TI-132. 1993. Geologic Setting of the 100-HR-3 Operable Unit, Hanford Site, South-Central Washington. K. A. Lindsey and G. K. Jaeger. Westinghouse Hanford Company, Richland, Washington.

WHC-SD-EN-TI-133. 1993. Geology of the 100-B/C Area, Hanford Site, South-Central Washington. J. W. Lindberg. Westinghouse Hanford Company, Richland, Washington.

WHC-SD-EN-TI-155. 1993. Geology of the 100-K Area, Hanford Site, South-Central Washington. J. W. Lindberg. Westinghouse Hanford Company, Richland, Washington.

WHC-SD-EN-TI-181, 1993. 100-D Technical Baseline Report. R. W. Carpenter. Westinghouse Hanford Company, Richland, Washington. 
WHC-SD-EN-TI-220. 1994. 100-B/C Area Technical Baseline Report. R. W. Carpenter, S. L. Cotè, D. H. Deford, and M. W. Einan. Westinghouse Hanford Company, Richland, Washington.

WHC-SD-EN-TI-239. 1994. 100-K Area Technical Baseline Report. R. W. Carpenter and S. L. Cotè. Westinghouse Hanford Company, Richland, Washington.

WHC-SD-EN-TI-248. 1994. 1994 Conceptual Model of the Carbon Tetrachloride Contamination in the 200 West Area at the Hanford Site. V. J. Rohay, K. J. Swett, and G. V. Last. Westinghouse Hanford Company, Richland, Washington.

WHC-SD-EN-TI-251. 1994. 100-N Technical Baseline Report. S. L. Cotè. Westinghouse Hanford Company, Richland, Washington.

WHC-SD-EN-TI-290. 1994. Geologic Setting of the Low-Level Burial Grounds. K. A. Lindsay, J. L. Slate, G. K. Jaeger, K. J. Swett, and R. B. Mercer. Westinghouse Hanford Company, Richland, Washington.

WHC-SD-EN-TI-292. 1994. Randall, R. R. Calibration of the Radionuclide Logging System Germanium Detector. Westinghouse Hanford Company, Richland, Washington.

WHC-SD-EN-TI-294, 1995. Hydrogeology of the 100-K Area, Hanford Site, South-Central Washington. J. W. Lindberg. Westinghouse Hanford Company, Richland, Washington.
WHC-SD-EN-TI-304. 1995. Vadose Zone Moisture Measurement Through Steel Casing Evaluation. J. E. Meisner. Westinghouse Hanford Company, Richland, Washington.

WHC-SD-EN-TI-306. 1996. Radionuclide Logging System In-Situ Vadose Zone Moisture Measurement Calibration. J. E. Meisner, R. K. Price, and R. R. Randall. Westinghouse Hanford Company, Richland, Washington.

WHC-SD-EN-WP-012, Rev. 1. 1995. Groundwater Screening Evaluation/Monitoring Plan - 200 Area Treated Effluent Disposal Facility (Project W-049H). D. B. Barnett, J. D. Davis, L. B. Collard, P. B. Freeman, and C. J. Chou. Westinghouse Hanford Company, Richland, Washington.

WHC-SD-ER-TI-003. 1991. Geology and Hydrology of the Hanford Site: A Standardized Text for Use in Westinghouse Hanford Company Documents and Reports. C. D. Delaney, K. A. Lindsey, and S. P. Reidel. Westinghouse Hanford Company, Richland, Washington.

WHC-SD-WM-TI-565, Rev. 1. 1993. Radionuclide and Chemical Inventories for the Single-Shell Tanks. R. J. Van Vleet. WASTREN, Inc. for Westinghouse Hanford Company, Richland, Washington.

WMNW-CM-004. 1998. Operational Environmental Monitoring. Waste Management Federal Services, Northwest Operations, Inc., Richland, Washington. 
-

- 


\section{Distribution List}

No. of

Copies

Offsite
No. of

Copies
A. Aldrich
Bureau of Land Management
U.S. Department of the Interior
Spokane District Office
1103 North Fancher
Spokane, WA 99212-1275
R. Alvarez
U.S. Department of Energy
U.S. Department of the Interior
P.O. Box 815
Ephrata, WA 98823
J. O. Boda
U.S. Department of Energy
Cloverleaf Building, EM-34
19901 Germantown Road
Germantown, MD 20874-1290
Forrestal Building, PO-5
1000 Independence Avenue, S.W.
Washington, D.C. 20585
J. A. Caggiano
330 Snyder
Richland, WA 99352
M. Ault
US Ecology, Inc.
P.O. Box 638
Richland, WA 99352
J.S. Bachmaier
U.S. Department of Energy
Forrestal Building, EH-412
1000 Independence Avenue, S.W.
Washington, D.C. 20585
J. R. Beaver, Mayor
T. E. Carpenter
Government Accountability Project
West Coast Office, Suite 1215
1402 3rd Avenue
Seattle, WA 98101
K. Campbell
Fish and Wildlife Service
U.S. Department of the Interior
P.O. Box 1157
Moses Lake, WA 98837
Kennewick City Council
210 West Sixth Avenue
Kennewick, WA 99336
M. E. Benitz, Jr.
Benton County Commissioner
P.O. Box 190
L. Campbell
Jason Associates
3250 Port of Benton Boulevard
Richland, WA 99352
J. Chasse
Energy Northwest
P.O. Box 968
Richland, WA 99352

J. Blanchard

Bureau of Reclamation 
No. of

Copies

J. Conaway

Los Alamos National Laboratory

P.O. Box 1663, MS J561

Los Alamos, NM 87545

2 Confederated Tribes of the Umatilla Indian Reservation

Environmental Planning/Rights Protection

P.O. Box 638

Pendleton, OR 97801

ATTN: T. Gilmore

J. R. Wilkerson

R. A. Danielson

Washington State Department of Health

5508 Englewood Avenue

Yakima, WA 98908

G. De Bruler

Columbia River United

P.O. Box 912

Bingen, WA 98605

2 B. W. Drost

Geological Survey

U.S. Department of the Interior

1201 Pacific Avenue, Suite 600

Tacoma, WA 98402

S. Foss

Washington State Department

of Agriculture

P.O. Box 42589

Olympia, WA 98504

\section{A.J.K. Fyall}

Benton County Planning Department

P.O. Box 910

Prosser, WA 99350
No. of

Copies

H. Gucinski, Chair

Pacific Northwest Natural Area Committee

3200 Jefferson Way

Corvallis, OR 97331

B. Thompson, Mayor

City of Richland

505 Swift Boulevard

Richland, WA 99352

M. K. Harmon

U.S. Department of Energy

Cloverleaf Building, EM-44

19901 Germantown Road

Germantown, MD 20874-1290

A. Haymaker

1721 Cottonwood Drive

Pasco, WA 99301

R. E. Isaacson

2106 Lee Boulevard

Richland, Washington 99352

R. E. Jaquish

Washington State Department of Health

1906 Peachtree Lane

Richland, WA 99352

P. Knight

Northwest Environmental Advocates/

Hanford Watch

133 Southwest Second Avenue, Suite 302

Portland, OR 97204-3526

K. T. Lang

U.S. Department of Energy

Cloverleaf Building, EM-38

19901 Germantown Road

Germantown, MD 20874-1290 
No. of

Copies

R. J. Leaumont

Lower Columbia Basin Audubon Society

9016 Sunset Terrace

Pasco, WA 99301

J. Leier

Walla Walla District

U.S. Army Corps of Engineers

Building 602, City-County Airport

Walla Walla, WA 99632-9265

R. Luxmoore

Oak Ridge National Laboratory

P.O. Box 2008, MS 6038

Oak Ridge, TN 37831-6038

L. Maas

Siemens Power Corporation

2101 Horn Rapids Road

Richland, WA 99352

J. Matuszek

JMM Consulting Services

82 McGuffy Lane

Delmar, NY 12054-4206

M. Nelson

Jacobs Engineering Group, Inc.

507 Knight Street, Suite B

Richland, WA 99352-4219

C. O'Neale

9106 Boulder Lane S.E., Apt. D

Olympia, WA 98501

R. Patt

1655 S. Elm $\# 405$

Canby, OR 97013
No. of

Copies

M. S. Peffers

Battelle Seattle Research Center

4500 Sand Point Way NE, Suite 101

P.O. Box 5395

Seattle, WA 98105-0395

G. M. Pollet

Executive Director

Heart of America, NW

Cobb Building, Suite 208

1305 Fourth Avenue

Seattle, WA 98101

R. K. Price

4200 W. 19th

Kennewick, WA 99338

L. Seelatsee

Wanapum Band

Grant County P.U.D.

30 "C" Street S.W.

P.O. Box 878

Ephrata, WA 98823

P. Sobotta

Nez Perce Tribe

Environmental Restoration/Waste

Management

P.O. Box 365

Lapwai, ID 83540-0365

South Columbia Basin Irrigation District 1135 S. Hillsboro Road

Pasco, WA 99301

2 State of Oregon Office of Energy 625 Marion Street N.E.

Salem, OR 97310

ATTN: D. Dunning

M.W. Grainey 
No. of

Copies

Washington State Department of

Ecology, MS 7600

P.O. Box 47600

Olympia, WA $98504-7600$

3 Washington State Department of Health

Division of Radiation Protection

P.O. Box 47827

Olympia, WA $98504-7827$

ATTN: M. Dunkleman

D. McBaugh

S. VanVerst

L. Stembridge

Executive Director

Hanford Education Action League (HEAL)

$1718 \mathrm{~W}$. Broadway Avenue \#203

Spokane, WA 99201-1818

L. C. Treichel

U.S. Department of Energy

Cloverleaf Building 2114, EM-44

19901 Germantown Road

Germantown, MD 20874-1290

2 Confederated Tribes and Bands

of the Yakama Nation

Environmental Restoration/Waste

Management

2808 Main Street

Union Gap, WA 98903

ATTN: R. Jim

W. Rigsby

P. Zielinski

U.S. Department of Energy

Cloverleaf Building

19901 Germantown Road

Germantown, MD 20874-1290
No. of

Copies

Onsite

34 DOE Richland Operations Office

C.A. Babel

H6-60

M. P. Blancq

A5-58

D. H. Chapin

R3-79

T. W. Ferns

$\mathrm{HO}-12$

B. L. Foley

M. J. Furman (6)

A5-13

A5-13

J. B. Hall

A2-15

R. D. Hildebrand (6)

A5-13

R. W. Lober

H6-60

J. K. McClusky

K9-18

R. G. McLeod

$\mathrm{HO}-12$

D. E. Olson

A5-13

G. L. Sinton

K. M. Thompson (5)

S7 -55

A5-13

A. C. Tortoso

D. C. Ward

$\mathrm{HO}-12$

A2-15

C. D. West

H6-60

H6-60

R. M. Yasek

Public Reading Room (2)

$\mathrm{H} 2-53$

7 Bechtel Hanford, Inc.

K. R. Fecht

HO- 02

B. H. Ford

HO-21

M. J. Graham

HO-O9

G. C. Henckel

HO-09

S. J. Trent

H9.03

T. M. Wintczak

$\mathrm{HO}-21$

J.P. Zoric

$\mathrm{X} 5-53$

6 CH2M Hill Hanford, Inc.

J. V. Borghese

HO- 19

R. L. Jackson

H9-02

R. F. Raidl

H9-02

V. J. Rohay

H0-19

L. C. Swanson

H9.02

R. L. Weiss 
No. of

Copies

2 DynCorp Tri-Cities Services, Inc.

H. B. Hathaway

L. M. Kelly

G3-07

S2-21

6 Fluor Hanford, Inc.

B. M. Barnes

T4-04

M. C. Brown

S. M. Price

F. A. Ruck

W. E. Toebe

J. D. Williams

Fluor Daniel Northwest, Inc.

F. M. Mann

HO-22

Jacobs Engineering Group, Inc.

D.L. Nichols

B2-05

A0.22

G1-37

G1-37

H8-67
No. of

Copies

7 Waste Management Technical Services

J. J. Dorian

H1-11

M. G. Gardner

H1-11

S. E. Kos

H1-11

K. M. McDonald

H6-06

D. J. Moak

H1-11

C. J. Perkins

H1-11

S. H. Worley

H1-11

3 Waste Management Federal Services of Hanford, Inc.

L. P. Diediker

G1-29

J. Sonnichsen

G1-30

M. I. Wood

H6-06

2 U.S. Environmental Protection Agency

L. E. Gadbois

B5-01

D. R. Sherwood

B5-01

111 Pacific Northwest National Laboratory

H. L. Boston

A7-50

A.J. Knepp

H0-22

E. A. Fredenburg

R1-56

D. A. Myers

HO-22

\section{MACTEC-ERS}

R. G. McCain

B1-42

6

Washington State Department of Ecology

B. L. Becker-Khaleel

B5-18

D. Goswami

B5-18

S. Leja

B5-18

Z. Maine-Jackson

B5-18

P. R. Staats

B5-18

M. A. Wilson

B5-18
D. H. Bacon

K9-33

D. B. Barnett

K6-81

D. J. Bates

K5-12

M. P. Bergeron

K9-36

C. A. Brandt

K6-85

R. W. Bryce

K6-75

J. W. Buck

K6-80

C. J. Chou

K6-81

C. R. Cole

K9-36

S. F. Conley

K6-75

R. L. Dirkes

K6-75

P. E. Dresel (20)

K6-96

M. J. Fayer

K9-33

M. D. Freshley

HO- 21

J.S. Fruchter

K9-96 
No. of

Copies

$\begin{array}{ll}\text { D. R. Geist } & \text { K6-85 } \\ \text { R. E. Gephart } & \text { K9-76 } \\ \text { B. M. Gillespie } & \text { K6-96 } \\ \text { T. J Gilmore } & \text { K6-81 } \\ \text { S. M. Goodwin } & \text { K6-81 } \\ \text { R. W. Hanf } & \text { K6-75 } \\ \text { M. J. Hartman (10) } & \text { K6-96 } \\ \text { P. S. Henry } & \text { K6-75 } \\ \text { F. N. Hodges } & \text { K6-81 } \\ \text { D. G. Hotton } & \text { K6-81 } \\ \text { V. G. Johnson } & \text { K6-96 } \\ \text { C. T. Kincaid } & \mathrm{K} 9-33 \\ \text { S. J. Kowall (5) } & \text { K6-96 } \\ \text { G. V. Last } & \text { K6-81 } \\ \text { E. A. Lepel } & \mathrm{P} 8-08 \\ \text { T. L. Liikala } & \text { K6-96 } \\ \text { J. W. Lindberg } & \text { K6-81 } \\ \text { P. E. Long } & \text { K9-33 } \\ \text { S. P. Luttrell (10) } & \text { K6-96 } \\ \text { J. P. McDonald } & \text { K6-96 } \\ \text { R. B. Mercer } & \text { K6-96 } \\ \text { L. F. Morasch } & \text { K6-86 } \\ \text { S. M. Narbutovskih } & \text { K6-81 } \\ \text { D. R. Newcomer } & \text { K6-96 } \\ \text { K. B. Olsen } & \text { K6-96 }\end{array}$

No. of

Copies

B. E. Opitz K6-75

R. E. Peterson K6-96

S. P. Reidel K6-96

J. T. Rieger K6-96

R. G. Riley K6-96

J. A. Serkowski K6-96

R. J. Serne K6-81

D. S. Sklarew K6-96

R. M. Smith K6-96

F. A. Spane, Jr. K6-96

D. L. Stewart K6-96

G. P. Streile K9-33

M. D. Sweeney K6-81

C. J. Thompson K6-96

P. D. Thorne K9-33

E. C. Thornton K6-96

V. R. Vermeul K6-96

W. D. Webber K6-96

R.S. Weeks P7.79

G. Whelan K9-36

B. A. Williams $\quad$ K6-81

M. D. Williams K9-36

S. K. Wurstner K9-36

Information Release Office (7) K1-06 